UNIVERSIDAD AUTÓNOMA METROPOLITANA UNIDAD IZTAPALAPA

División de Ciencias Sociales y Humanidades

\title{
LA REPRESENTACIÓN HOMOERÓTICA EN EL
}

\section{CUENTO MEXICANO}

\author{
TESIS \\ Que para optar por el grado de \\ DOCTOR EN HUMANIDADES \\ (Línea de Teoría Literaria)
}

Presenta

Mtro. Víctor Saúl Villegas Martínez

Asesor

ginsas

Dr. Jesús Eduardo García Castillo

México, D.F.

Octubre de 2014 
A Edith, Victor y David 
Deseo agradecer enormemente al Consejo Nacional para la Ciencia y la Tecnología, que me ha brindado, a lo largo de varios años, el apoyo necesario para realizar mis investigaciones de posgrado. Igualmente, quiero expresar mi gratitud a la Universidad Autónoma Metropolitana, especialmente a la División de Ciencias Sociales y Humanidades de la Unidad Iztapalapa, que me proporcionó una calurosa estancia desde 2011 hasta la fecha.

En esta misma línea de la formación académica, dejo muestra de mi aprecio y gratitud al dr. Jesús Eduardo García Castillo, paciente, cordial y benévolo asesor que me orientó y apoyó con dedicación; sin su puntual participación y atinadas observaciones no habría podido concluir adecuadamente el trabajo de investigación doctoral que ahora presento. Otra persona a quien quiero dejar constancia de su apoyo es a la lic. Adriana López Gómez, sobre todo por haberme facilitado notablemente el tránsito dentro de este programa de estudios en cuanto a cuestiones administrativas se refiere.

Es preciso mostrar mi gratitud también por la dra. Guadalupe Flores Grajales, lectora, maestra, madre adoptiva y amiga, cuyo ánimo y orientación desde el inicio de mi formación universitaria, hace ya más de diez años, me ha permitido llegar a este momento. Igualmente, quiero dar las gracias al dr. Alfredo Pérez Pavón, quien puso su confianza en mi labor de investigación desde mis estudios de maestría y que me contagió de su entusiasmo y disciplina por el arduo trabajo de la crítica literaria. Estas dos personas forman parte imprescindible de mi formación académica y mi afecto hacia ellos es enorme.

En el ámbito familiar, debo agradecer la presencia de mis padres, Edith Martínez Rivera y Víctor Manuel Villegas Pérez, que, hasta el día de su muerte, me impregnaron de amor y apoyaron todos mis proyectos. Ahora, a pesar de su 
ausencia, tengo su recuerdo presente a cada momento y me ha servido para continuar mi formación y pensar en el futuro. Por otro lado, desde la infancia me enseñaron a amar y respetar la palabra, sobre todo la escrita, por lo que considero que mi pasión por la literatura nació desde esos instantes. Espero que este trabajo sirva, de modo alguno, para honrar su memoria y su labor como padres, la cual desempeñaron cabalmente. Además, pienso que cualquier agradecimiento o dedicatoria es demasiado minúsculo para retribuir todos los años de su vida que me dedicaron sin aguardar otra cosa a cambio; sin duda, esto último ha sido uno de los ejemplos más gratos de mi existencia. Por estos motivos, no he cesado de dedicarles cada logro académico, y considero que éste es uno de los más pertinentes para reiterarles mi enorme gratitud.

De igual modo, quiero agradecer a David Hernández Hernández y a su familia todo el amor, paciencia y hospitalidad brindados durante los últimos seis años. Él supo apoyarme en momentos muy difíciles e impulsarme, con su tenacidad, a concluir e iniciar nuevos proyectos, entre los cuales se encontraba el recorrido por mis estudios de posgrado. Igual que con mis padres, espero que esta dedicatoria y agradecimiento sirva para retribuir su complicidad y afecto. 
Índice

Introducción $\quad 6$

Concepciones del homoerotismo en México 19

Estudios sobre literatura mexicana de contenido homoerótico $\quad 98$

$\begin{array}{ll}\text { Antecedentes } & 125\end{array}$

$\begin{array}{ll}\text { Exploración (1921-1960) } & 161\end{array}$

Consolidación (1961-1990) 193

Cuestionamiento (1991-2011) 252

$\begin{array}{ll}\text { Conclusiones } & 288\end{array}$

$\begin{array}{ll}\text { Bibliografía } & 295\end{array}$ 
Introducción

El vínculo entre el acontecimiento literario y el problema de la identidad es bastante estrecho. Sin duda, la escritura desvela concepciones del mundo de forma inesperada y responde maravillosamente a cualquier interrogante planteado sobre los conflictos entre el ser y el parecer del sujeto. Por tanto, no resulta para nada extraño que el homoerotismo, siendo una parte de la sexualidad del hombre soterrada por prejuicios de cualquier índole, aparezca de modo subrepticio y, a la vez, genere un desasosiego en el proceso de la creación, la lectura y la formación de un canon.

En consecuencia, este trabajo busca establecer una suerte de planos paralelos mediante los cuales puede observarse el desarrollo del tema de la disidencia sexual en el cuento mexicano y, claro está, la relación entre éste y la sociedad de cada uno de los tiempos a los que aluden los relatos aquí estudiados. La tarea está determinada entonces por una idea secuencial en donde convergen puntos de análisis múltiples para encontrar las diferentes representaciones del homoerotismo en el artefacto literario ya mencionado.

En general, la presencia del tema de la homosexualidad en la literatura mexicana ha sido, durante largo tiempo, un hecho callado y, en buena medida, es hasta la segunda mitad del siglo XX cuando se da una gran eclosión de textos que abordan el tema. Sin duda, algo que ayudó a detonar esta situación fue la emergencia del movimiento de la contracultura durante la década de los sesenta y setenta. Antes de estas fechas, la exhibición del tópico quedada restringido a muy pocas líneas y es difícil rastreaerlo; no obstante, el objetivo de esta investigación es presentar las diversas eclosiones del homoerotismo en una de las líneas de creación literarias más fecundas: el cuento. 
Ahora bien, y en cuanto a la crítica se refiere, las últimas dos décadas han sido fructíferas en el estudio de la literatura gay mexicana. Considerado como tema tabú hasta hace algunos años, la homosexualidad dentro de la literatura no había sido observada con detenimiento ni, mucho menos, se le había dedicado un estudio sistemático. Es en la década de los noventa del siglo pasado cuando inicia en México una auténtica apertura hacia las identidades sexuales "disidentes" y que surge, en el ámbito de los estudios literarios, un profundo interés por investigar la escritura gay. Aparecen entonces estudios como el de Luis Mario Schneider, La novela mexicana entre el petróleo, la homosexualidad y la política (1997), o la antología de cuentos de Mario Muñoz titulada De amores marginales (1996). Por estos mismo años, Antonio Marquet inicia la redacción de sus artículos sobre la cultura y literatura gay mexicanas que, posteriormente, serán compilados en ; Que se quede el infinito sin estrellas! (2001) y El crepúsculo de Heterolandia (2006). No puede olvidarse aquí también la relevancia de los ensayos de Carlos Monsiváis elaborados sobre el tema y publicados a lo largo de estas últimas dos décadas en Debate Feminista, y compilados en el volumen Que se abra esa puerta; en fechas más recientes, se encuentra México se escribe con $J$, en el cual se hace un amplio recorrido no sólo por la literatura mexicana de corte homosexual, sino por las diferentes expresiones artísticas y culturales en las que ha tenido cabida dicha expresión.

En esta tradición crítica de los estudios sobre la literatura gay es donde se inserta la presente investigación acerca del cuento mexicano de temática homosexual $\mathrm{y}$, sus antecedentes, están situados en dos trabajos previos acerca del tópico: Háblame de ti, cuéntame de tu vida. Antología crítica del cuento gay hispanoamericano (1968-2008) (2009) y El personaje gay en seis cuentos mexicanos. Un acercamiento crítico desde la perspectiva 
de género, los estudios gay y la teoría queer (2011). Ambas investigaciones fueron realizadas por el autor del presente trabajo para acceder, respectivamente, a los títulos de licenciatura y maestría. La razón principal de crear estas investigaciones sobre el cuento gay fue el vacío notado al respecto del tema en los estudios críticos sobre la literatura de corte homosexual. A excepción de la antología de Mario Muñoz, algunos artículos de Antonio Marquet y el acercamiento realizado por José Ricardo Chaves a la figura del "afeminado" en la literatura decimonónica mexicana, la mayor parte de las investigaciones hechas sobre la expresión escrita homoerótica han versado sobre la novela y la poesía. El mismo Luis Mario Schneider menciona, en su recorrido hecho por la novela gay mexicana, que no hablará, dado su objeto de estudio, de "cuentos que recogen el tema aisladamente, pero cuyos nombres menciono: $E l$ vino de los bravos de Luis González de Alba, Los Magos de A. López Chavira, Opus 123 de Inés Arredondo, o las narraciones de Gonzalo Martré, de Fidencio González, José Ceballos Maldonado, Alberto Dallal, Luis Arturo Ramos, Agustín Monsreal, Raúl Hernández, etcétera". ${ }^{1}$ De este modo, La representación homoerótica en el cuento mexicano ayudará, en gran medida, a llenar este vacío de información al respecto y servirá para hacer un repaso por las diversas formas de expresión homosexuales advertidas en la cuentística del país: desde la presencia del travestido y el sujeto con una "masculinidad disminuida" en el siglo XIX, hasta el reciente cuestionamiento sobre las representaciones de la disidencia sexual, atravesando, claro está, la gran cantidad de voces reunidas alrededor de la identidad gay en las décadas finales de la centuria pasada.

Luis Leal mencionó en su Breve historia del cuento mexicano (1956) la enorme tradición cuentística del país debida a los narradores que trabajaban tanto la novela como el

\footnotetext{
${ }^{1}$ Luis Mario Schneider, La novela mexicana entre el petróleo, la homosexualidady la política (México: Nueva Imagen, 1977), p. 45.
} 
relato. Esta situación, según Leal, arrojaba un volumen gigantesco de cuentos por la enorme cantidad de autores dedicados al mismo. El crítico señalaba también al cuento como un género de escasa dedicación exclusiva: los narradores mexicanos rara vez escribían sólo cuentos y, mayormente, alternaban el relato con la hechura de novelas. La situación a la fecha persiste y es muy común ver a escritores dedicados a la narrativa breve y a la extensa. Una situación similar ocurre con el cuento de tema homosexual. Existe una línea de narradores consagrados casi por completo a la literatura gay -Luis Zapata, José Joaquín Blanco, Luis González de Alba y Jorge Arturo Ojeda, por poner algunos ejemplos-, frente a otros que tocan el tema de forma tangencial en alguno de sus textos -Luis Arturo Ramos, Jorge López Páez, Agustín Monsreal, Eduardo Antonio Parra y Ana Clavel, entre otros-, pero ambos grupos se han dedicado a cultivar alternativamente el cuento y la novela. El hecho, lejos de perjudicar la cuentística mexicana, la engrandece, porque, como el mismo Leal decía, amplían la variedad y riqueza del relato mexicano.

Ahora bien, los textos seleccionados para exponer el tema del homoerotismo en el cuento mexicano son los siguientes: "Manolito el pisaverde" de Ignacio Rodríguez Galván, “Aventura de carnaval” de Amado Nervo, "La excursionista" de Federico Gamboa, "Retrato de un estudiante" de Jaime Torres Bodet, "Los machos cabríos" de Jorge Ferretis, "Los Malabé” de José de la Colina, "Los amigos” de Juan Vicente Melo, “Doña Herlinda y su hijo" de Jorge López Páez, "Perder a Orfeo" de Luis González de Alba, “De amor es mi negra pena” de Luis Zapata, “Amor propio” de Enrique Serna y “¿Te gusta el látex, cielo?” de Nadia Villafuerte. Como podrá percatarse el lector, los textos mencionados corresponden a diferentes normas estéticas que van desde el Romanticismo del siglo XIX hasta la plena efervescencia de la Posmodernidad en el XIX. Esta circunstancia permite hacer un recorrido 
muy amplio que, claro está, inicia en los primeros años del México independiente y termina hasta poco antes de la elaboración de este trabajo de investigación.

Los cuentos aquí analizados articulan un discurso directo al respecto de la representación de la homosexualidad en el ámbito de las letras y la geografía mexicanas; sin embargo, debido a cuestiones temporales, sociales, culturales y literarias, se ha preferido organizar los trece cuentos mencionados en torno a cuatro capítulos: "Antecedentes (19211920)", "Exploración (1921-1960)", “Consolidación (1961-1990)” y "Cuestionamiento (1991-2014)". Claro está, que las fechas colocadas en los títulos de estos capítulos corresponden a los años en los cuales fueron publicados los cuentos en cuestión y permiten crear un seguimiento de índole historiográfico, que lejos de ser un lastre o anclar la perspectiva sobre los textos, amplían los horizontes de expectativas al respecto de la interpretación. A su vez, el carácter de este trabajo favorece esta agrupación, ya que instala al lector en una convergencia de espacio-tiempo bien determinada. No obstante, antes de ingresar a las cuestiones analíticas del objeto literario, fue preciso colocar otros dos apartados que llevan por título "Concepciones del homoerotismo en México" y "Estudios sobre la literatura mexicana de contenido homoerótico". Ambos capítulos entablan un diálogo directo con la cultura y la literatura del país con el fin de establecer bases de análisis y antecedentes con respecto a la labor de crítica aquí hecha.

Así pues, el primer apartado, "Concepciones del homoerotismo en México" es una breve síntesis de la visión tenida sobre la disidencia sexual en México. Por tanto, este capítulo abarca un recorrido histórico-cultural que va de la época prehispánica y llega a la actualidad. El resultado de este apartado es el advertimiento claro de un paradigma sexual cuya normativa estriba en las conveniencias de los diversos dispositivos de poder. Así, los cambios efectuados en la cosmovisión de la sexualidad en México están sujetos no tanto a las 
necesidades de los individuos que la practican, sino a merced de un aparato jurídico religioso cuya misión consiste en sancionar o elogiar determinadas conductas sexuales. Un ejemplo de esta situación es la permisividad de la "homosexualidad" por parte de algunas culturas prehispánicas, en correspondencia con el rechazo absoluto tenido por la visión judeocristiana establecida por los ibéricos en la Nueva España. La sodomía emerge en el periodo colonial como uno de los pecados más sancionados, cuya condena alcanza el desprestigio social y, en múltiples ocasiones, la muerte. El caso más documentado y mencionado de la sodomía durante el periodo colonial lo constituye el proceso erigido en contra de Cotita de la Encarnación y demás amistades practicantes del "vicio nefando", cuyo castigo fue la hoguera. Este proceso inquisitorial puede ser una muestra de lo ocurrido a lo largo de trescientos años en contra de la disidencia sexual, entendida, principalmente, bajo la noción de pecado.

Con el inicio de México independiente hay un cambio en la concepción de la disidencia sexual: el pecado se transforma en un delito, y su sanción no corre a cargo de una institución religiosa, sino gubernamental. Durante el siglo XIX, el "sodomita" es denominado, mayormente, como invertido y su visibilidad pública es nula, sólo se le muestra cuando es necesario criminalizarlo y ponerlo como ejemplo de lo inadecuado para la joven nación mexicana. Más adelante, a principios del siglo XX, y por influencia del discurso "higienista" europeo, el disidente sexual adquiere la categoría de enfermo y se busca su rápida incorporación al proceso productivo de la sociedad. Sí, aún existe la noción del delito; sin embargo, la conmiseración y el discurso pseudocientífico decimonónico lo advierten como un sujeto con alteraciones patológicas y alguna posibilidad de cura.

La visión mexicana sobre el homoerotismo guarda, en la actualidad, resabios de los discursos políticos, religiosos y médicos anteriores. No obstante, el siglo pasado ha dado la 
principal vuelta de tuerca a estos paradigmas y arranca al disidente sexual estas abrumadoras categorías. Los movimientos de liberación sexual de las últimas décadas han trastrocado por completo esta visión, y se ha hecho un enorme cambio en la sexualidad mexicana al grado de cuestionar los estamentos hegemónicos de la misma y, por tanto, su capacidad de marginar. De este modo, el capítulo inicial de esta investigación rastrea y ofrece la perspectiva histórica y cultural de una sexualidad cuya abyección, socialmente hablando, ha llevado a sus practicantes a un hondo rechazo, invisibilidad y flagelo.

El segundo capítulo es un breve estado de la cuestión acerca de los diversos trabajos elaborados en torno a la literatura de contenido homoerótico. Aparecen aquí los aportes de David William Foster, Antonio Marquet, Carlos Monsiváis, Luis Mario Schneider y Mario Muñoz, entre otros. Este apartado tiene dos objetivos: enlazar las concepciones ya mencionadas sobre el homoerotismo en México con el posterior análisis de los cuentos seleccionados e insertar esta investigación en la tradición crítica de la literatura gay mexicana. Este apartado incluye, también, una introducción acerca de los estudios hechos sobre la cuentística mexicana en general con las contribuciones de Luis Leal, Alfredo Pavón, Lauro Zavala y Emmanuel Carballo, por sólo mencionar algunos.

El estado de la cuestión correspondiente a este segundo apartado verifica la existencia de una crítica muy sostenida ya al respecto de la literatura mexicana de tema gay, o, en general, de la disidencia sexual en cualquiera de sus manifestaciones. Como se mencionó algunas líneas atrás, los trabajos de investigación relativos a este rubro son numerosos y consignan una variedad de representaciones, en las cuales destaca la pugna entre las formas de sexualidad marginales y el plano hegemónico que las vuelve periféricas. Por otro lado, en el caso del cuento, es más escaso el trabajo crítico, ya que, en muchas ocasiones, éste sólo forma parte de un trabajo mayor referido a una visión global sobre la literatura mexicana; es 
decir, que en un mismo estudio aparecen alusiones a la novela, a la poesía o al cuento de tema homosexual sin dedicarse, en exclusiva, a alguno de los géneros.

En este caso, las antologías han servido de mucho para orientar la lectura y aglutinar textos que giran en torno a línea temática y de género literario similar. En el caso que aquí compete, la única que se ha realizado es De amores marginales de Mario Muñoz, quien compila en un práctico e interesante volumen dieciséis cuentos relativos al tema gay. A su vez, este trabajo está precedido de una introducción que hace un breve repaso por las diversas manifestaciones del homoerotismo en la narrativa mexicana. Un trabajo igual de importante que el anterior al respecto del estudio del cuento mexicano de tema homoerótico está representado por las compilaciones de artículos de Antonio Marquet $-i Q u e$ se quede el infinito sin estrellas! y El crepúsculo de Heterolandia-. En ambos libros existe una considerable cantidad de información bien organizada y pertinente que sirve de anclaje para determinar las definiciones, valores y procesos de lectura que forman parte entrañable de la crítica literaria elaborada en torno al tema referido. En consecuencia, este segundo apartado sirve para crear un puente con el anterior y los diversos análisis que siguen, igualmente proporciona la tradición crítica de la cual este trabajo es heredero y, por tanto, pertenece.

Ahora bien, el primer apartado, de los concernientes a los capítulos dedicados a los análisis de los cuentos en cuestión, es “Antecedentes”, el cual tiene como meta establecer un diálogo inicial en torno al tema del homoerotismo en la literatura mexicana con base en el análisis tres cuentos: "Manolito el pisaverde" (1838) de Ignacio Rodríguez Galván, "Aventura de carnaval" (1895) de Amado Nervo y "La excursionista" (1915) de Federico Gamboa. Estos textos abordan en el tópico de la investigación desde la perspectiva del personaje travestido y, por tanto, exhiben un lúdico y evidente conflicto entre su representación y el habitus mexicano de su época. 
"Manolito el pisaverde" es un cuento exquisitamente romántico en el cual aparece una protagonista, María, obsesionada por recuperar a su esposo. Para cumplir dicho fin, adquiere una indumentaria masculina que le permite moverse con desahogo dentro de la sociedad de la capital mexicana y cumplir, de esta forma, su deseo. "Aventura de carnaval" es una gran alegoría en torno a la máscara, dado que la representación de género con base en el vestido resulta una alusión clara a la adquisición de la identidad por parte de un individuo para convertirse en sujeto; por esta razón, cuando Carlos, el primo del narrador, adquiere una vestimenta femenina con la finalidad de seducir a este último juega con la performatividad del estatuto de género y desenmascara, como en el cuento de modo subrepticio se menciona, la parafernalia existente detrás de la indumentaria adjudicada a uno y otro sexo. "La excursionista" aborda el mismo tema de los dos cuentos anteriores y muestra a una protagonista joven de origen estadounidense, Eva Blackhill, que, al parecer, realiza un viaje de negocios a la Ciudad de México casi a fines del porfiriato; no obstante, un joven capitalino sucumbe ante la belleza de ésta y acaba totalmente enamorado. A partir de esta circunstancia, el joven realiza toda suerte de escaramuzas para acercarse a Eva, quien, en las últimas líneas del texto, es descubierta por su enamorado y, tanto éste como los lectores del cuento, quedan atónitos ante la presencia de un filibustero texano que ocupa el ardid del travestimiento para ocultarse de sus detractores.

Como se advierte, la representación del personaje que modifica su indumentaria, impuesta por un determinado dispositivo de género, evidencia los artilugios constructivos ocultos tras la naturalidad de dicho sistema. Manolito, Carlos y Eva apuestan por esta fractura y reelaboran las lecturas sociales establecidas sobre su cuerpo para crear con él una identidad en concordancia con sus objetivos. A su vez, el gesto de la disidencia sexual queda 
plasmado en los tres textos cuando plantean un posible acercamiento homoerótico entre sus personajes.

Algo diferente ocurre en los cuentos estudiados en el capítulo siguiente, "Exploración (1920-1960)", en el cual se realiza un análisis de "Retrato de un estudiante" (1929) de Jaime Torres Bodet, "Los machos cabríos" (1952) de Jorge Ferretis y “Los Malabé” (1959) de José de la Colina. Nuevamente, se trata de tres textos que exhiben el trastrueque de la linealidad sexo/género/deseo al presentar personajes heterodoxos con respecto a la sexualidad mexicana dominante; sin embargo, no ocurre ya la presencia del personaje travestido.

El acontecimiento homoerótico en estos cuentos es señalado desde un extraordinario estado de deseo que intenta romper con cualquier tipo de dominación; no obstante, sólo uno de estos tres personajes logra sobreponerse a la embestida de su entorno, y éste es el que aparece en "Retrato de un estudiante", quien inicia un proceso doloroso de destitución de una identidad sexual instaurada desde fuera para acercarse a otra que le parece más justa con respecto a sus aspiraciones. Por otro lado, los protagonistas de los "Los machos cabríos" y de "Los Malabé" son arrastrados y, en su momento, destruidos por la tiranía de sus respectivos espacios de convivencia: Filemón, protagonista del cuento de Ferretis, es sometido a una operación de "cambio de deseo" y pasa, admirablemente, de un denotado afeminamiento a una virilidad extravagante; por otro lado, Francisco, personaje del texto de José de de la Colina, permanece celosamente resguardado por la figura de dos hermanas profundamente conservadoras. Por tanto, la perspectiva tenida sobre el homoerotismo está sujeta a un anclaje médico y religioso que impide al personaje realizar su vida de modo pleno, sólo el texto de Torres Bodet, en este caso, plantea un inusitado comming out que resulta muy emblemático por la fecha de su publicación y el ámbito tan sórdido y hermético al cual se enfrenta. 
El siguiente apartado, "Consolidación (1961-1990)" es, sin duda, el más extenso de esta investigación. Esto se debe, en primer lugar, a la cantidad de cuentos ahí estudiados, así como a las diferentes posturas de interpretación que pueden desprenderse de ellos. El relato que abre el recorrido de este capítulo es "Los amigos" de Juan Vicente Melo, en el cual hay un enfrentamiento claro en la perspectiva que los propios personajes tienen sobre su sexualidad. El texto exhibe, por estos motivos, una clara alusión al tema de la automarginación y a la interiorización de la norma: el narrador se enfrenta a un universo altamente demandante en cuanto a la configuración de una identidad heterosexual y prestigiada se refiere. El siguiente cuento, "Doña Herlinda y su hijo" de Jorge López Páez, articula un discurso jocoso, pero no por eso dista de ser muy diferente del anterior. En este caso, los personajes que comparten una relación homosexual viven sometidos por un yugo matriarcal que, lejos de configurar para ellos un espacio de posible libertad, los induce a vivir una doble vida con el fin de congraciarse con la colectividad.

Una situación absolutamente contraria ocurre en "Perder a Orfeo", de Luis González de Alba, en este cuento el protagonista posee una vida exacerbada que le permite vivir sin mayor tabú su preferencia sexual; sin embargo, su principal problema es el enfrentamiento con una norma social y estética arraigada profundamente en el ámbito homoerótico, la cual es una copia casi exacta de su contraparte heterosexual. Con esto, el protagonista se sumerge en un recorrido utópico por los vericuetos del deseo hasta alcanzar aquello que desea o, con mayor exactitud, fracasar en el proyecto.

Un autor que no podía quedar al margen de una investigación como ésta es Luis Zapata, y el cuento seleccionado para formar parte de este recorrido es "De amor es mi negra pena". En dicho texto hay una articulación inapelable de un machismo y una heterosexualidad compulsiva, las cuales, en su frenético domino, terminan por acercarse a un 
marcado homoerotismo. Los protagonistas del cuento viven sujetos a este dispositivo; no obstante, en algunos momentos logran desprenderse de él y alcanzar una pequeña libertad de flirteo, aunque esto puede costar la representación social prestigiada o, en el peor de los casos, la vida. Por estas razones, el relato se convierte en un excelente exponente de las formas más abigarradas de la cultura y las afirmaciones del género y la sexualidad creadas en ella.

El último capítulo, “Cuestionamiento (1991-2014)”, es el más breve de los dedicados al análisis y concentra la interpretación de dos cuentos "Amor propio", de Enrique Serna, y “¿Te gusta el látex, cielo?”, de Nadia Villafuerte. Este apartado se dedica a advertir los mecanismos mediante los cuales la representación gay se convierte en una circunstancia hegemónica, muy cercana los modos de representación de la heterosexualidad hegemónica. En consecuencia, los protagonistas de los relatos en cuestión rompen con un posible marco de deseo para destruir cualquier revestimiento del deseo. Así, en el caso de "Amor propio" el lector se enfrenta a una sigilosa artimañana sexual para confrontar dos personajes en apariencia iguales. Mientras que en “¿Te gusta el látex, cielo?” se produce una auténtica rebelión contra la estigmatización del deseo travesti, sujetado a las reglas de la heteronormatividad, para suscitar un extraño encuentro entre identidades correspondientes a escaños sexuales absolutamente diferentes.

Como se advierte, el recorrido que se pretende hacer por el cuento mexicano siguiendo la línea temática del homoerotismo propone una lectura de la sexualidad al interior de la sociedad mexicana. Asimismo, significa un acercamiento desde las teorías de género, los estudios gay latinoamericanos y la teoría queer para señalar las características principales que la homosexualidad adquiere dentro de la producción cuentística nacional. Es, también, un repaso por uno de los géneros más cultivados dentro de la literatura mexicana que, como bien lo han señalado numerosos críticos -Luis Leal, Alfredo Pavón, Lauro Zavala, Emmanuel 
Carballo y Russell M. Cluf, entre muchos otros-, ha servido para exponer los problemas más intrínsecos de la realidad nacional. 
Concepciones del homoerotismo en México

La sexualidad es un constructo social con etapas y facetas diferentes relacionadas directamente con el momento histórico en el que se encuentran inmersas. México no escapa a esta consigna y crea un discurso sobre la sexualidad muy cercano a las formas de concebir la realidad social. Múltiples paradigmas han intervenido en la creación de una sexualidad institucionalizada y, por tratarse de una nación heterogénea, éstos han configurado un complejo plano de correspondencias simbólicas vertido sobre la visión del cuerpo. La sexualidad pasa, entonces, de ser un hecho placentero a ser un verdadero acontecimiento político, donde las pautas de comportamiento son dictadas conforme a la conveniencia de un estatuto hegemónico.

La forma de establecer un contacto erótico está reglamentada con base en una profunda y arraigada costumbre de concebir el género como algo estático e inmutable. La sexualidad cae dentro de esta visión y es promovida mediante una serie de normas cuyo fin es establecer un dominio permanente sobre el ser humano y orientar su ejecución a una meta reproductiva. El cuerpo es cargado con una serie de obligaciones y prohibiciones cuya prioridad radica en la sumisión absoluta del mismo. La sexualidad es encerrada dentro de esta imbricación de reglas y olvida su objetivo placentero para transformarse en un suceso hermético: la forma de vincularse sexualmente con los otros termina enclaustrada en un corsé simbólico altamente delimitado. 
Uno de los principales estudiosos de la sexualidad e inspirador de diversas teorías acerca de la misma, Michel Foucault, ${ }^{2}$ ha destacado los medios y formas utilizados por los aparatos jurídicos, sociales y religiosos para controlar la vida del hombre a través del dominio absoluto de su erotismo. Foucault señala cómo el dispositivo de la sexualidad ha sido elaborado con base en un principio estrechamente relacionado con el poder: "Decir que el sexo no está reprimido o decir más bien que la relación del sexo con el poder no es de represión corre el riesgo de no ser sino una paradoja estéril". ${ }^{3} \mathrm{El}$ dispositivo de la sexualidad es creado y modificado a partir de una estrategia discursiva, cuya conveniencia apela a un estadio constante de dominación: los deseos y pulsiones del individuo quedan sometidos a un paradigma representativo de las necesidades de una determinada jerarquía reinante.

Una situación similar plantea Monique Wittig cuando señala la similitud entre el origen de la opresión por clase y sexo: "La continua presencia de los sexos y la de los amos provienen de la misma creencia. Como no existen esclavos sin amos, no existen mujeres sin hombres. La ideología de la diferencia sexual opera en nuestra cultura como una censura en la medida en que oculta la oposición que existe en el plano social entre los hombres y las mujeres poniendo a la naturaleza como su causa". ${ }^{4} \mathrm{Y}$, además, agrega: "Masculino/femenino, macho/hembra son categorías que sirven para disimular el hecho de que las diferencias sociales implican siempre un orden económico, político e ideológico. Todo sistema de

\footnotetext{
${ }^{2}$ Historia de la sexualidad: la voluntad de saber, vol.1, trad. de Ulises Guiñazú (México: Siglo XXI, 1996). Historia de la sexualidad: el uso de los placeres, vol. 2, trad. de Martín Soler (México: Siglo XXI, 1986). Historia de la sexualidad: la inquietud de sí, vol. 3, trad. de Tomás Segovia (México: Siglo XXI, 1987). Vigilary castigar, trad. de Aurelio Garzón del Camino (México: Siglo XXI, 1976). Un diálogo sobre el poder, trad. de Miguel Morey (Madrid: Alianza, 1981). Los anormales. Curso en el Collège de France (1974-1975), trad. de Horacio Pons (Buenos Aires: FCE, 2000).

${ }^{3}$ Foucault, Historia de la sexualidad, v.1, p. 15.

${ }^{4}$ Monique Wittig, Elpensamiento heterosexual y otros ensayos, trad. de Javier Sáenz y Paco Vidarte (Madrid: Egales, 2006), p. 22.
} 
dominación crea divisiones en el plano material y en el económico". ${ }^{5}$ En esta última oración de Wittig radica la diatriba respecto de la relación entre la sexualidad y el poder: cuando un aparato jurídico inserta redes inasibles de jerarquización -pero profundamente corrosivas en su capacidad opresiva y de destrucción-, a partir de la regulación del erotismo entre los individuos, controla de antemano la mayor parte de su existencia. De esta forma, la sexualidad es anclada en una cómoda inamovilidad y naturalización para el aparato jurídico y demás sistemas de dominación social.

Generalmente, la forma discursiva utilizada para implantar una sexualidad determinada tiene como base un axioma que plantea la problemática del sexo más allá del inicio de la vida social. Este principio crea la idea de una sexualidad preexistente, es decir, se asegura su justificación en una fundamento anterior -divino o natural, según sea el casopara el cual se proporciona la imagen de una ley incapaz de enmendar, pero sí de regular: si la sexualidad es un hecho "natural" ¿cómo puede realizarse una modificación a la misma? Desde este principio, el discurso de la legitimidad de un dispositivo de la sexualidad dado posee una validez universal. Además, esta posición inalterable es dispersada entre los individuos con mecanismos culturales tan abigarrados que, pocas veces, se cuestiona su veracidad. ${ }^{6}$

Este axioma sobre la "naturalización" de una sexualidad -que en realidad es construida con base en un sistema de poder-, trae a colación el problema de los sexos. El discurso de la hegemonía observa a la sexualidad como el resultado inherente de la diferencia sexual entre los individuos. Siguiendo este paradigma, no habría una sexualidad sin cuerpos

\footnotetext{
${ }^{5}$ Loc. cit.

${ }^{6}$ Véase: Judith Butler, Mecanismos psíquicos del poder: teorías sobre la sujeción, trad. de Jacqueline Cruz (Madrid: Cátedra, 2001).
} 
sexuados o, dicho de otra forma, las dos posibilidades genéricas del sujeto -masculino o femenino- son, según los discursos legitimadores del poder, los causantes de la sexualidad. Así, la implantación de un dispositivo de la sexualidad obedece "naturalmente" a las dicotomías biológicas observadas ${ }^{7}$ en el cuerpo de los individuos. El discurso legitimador del poder plantea, entonces, a la sexualidad como el producto inmediato de una "realidad corpórea".

En realidad, todos estos discursos instalados sobre el sexo biológico para legitimar una sexualidad natural encubren un mecanismo que opera a la inversa: la sexualidad es la hacedora de los cuerpos sexuados, de los cuales partirán el género y el deseo institucionalizados. Esta situación puede ejemplificarse claramente con el concepto "matriz heterosexual" de Wittig. Cuando la autora postula la idea de una opresión consensuada contra las identidades poco prestigiadas al interior de la sociedad heteronormada, formula la imagen de un dispositivo inmenso, cuya cobertura se extiende a todos los ámbitos del ser humano. Este dispositivo, denominado "matriz heterosexual", crea las identidades -no sólo las aceptadas, sino también las rechazadas- con las cuales fundamentará su hegemonía. En la cultura judeo-cristiana vertida por todo Occidente, la "matriz heterosexual" aparece como un hecho indisoluble de la sociedad: es imposible pensar una cultura que no esté enfocada a la procreación y dicotomía del género. Así, la imagen de la sexualidad institucionalizada como un corsé ceñidor de cada uno de los cuerpos sujetos a una convención no es algo ficcional. ${ }^{8}$

\footnotetext{
7 El objetivo de colocar en cursivas la palabra "observadas" radica en todo el planteamiento construccionista instalado detrás de esta supuesta observación, cuya logística reside en la capacidad de advertir, con base en los datos biológicos de la diferencia sexual, la posibilidad de un género seguido a cabalidad por el individuo. De este modo, la misma categoría de sexo, resulta, en gran medida, un andamiaje cultural sobre el que está sostenida la correspondencia genérica entre los sujetos.

${ }^{8}$ Esta situación aparece claramente resumida en la siguiente cita de Mauricio List Reyes: "Es un hecho que las sociedades tienen una gran cantidad de formas simbólicas y objetivas por las que se transmite al individuo todo el conjunto de valores y principios éticos y morales que las norma, estableciendo límites
} 
Por ello, para la existencia de una heteronormatividad, debe crearse un modelo de "varón” y "hembra", socialmente hablando, que, posteriormente, impulsará los géneros "hombre" y "mujer". La sexualidad institucionalizada no es aquí un elemento fabricado a partir de los cuerpos, sino un dispositivo de poder creador de sujetos regulados con base en sus normas. Así, la heterosexualidad debe crear al "hombre" y a la "mujer" para subsistir, pero, a la vez, tiene que poseer la capacidad de edificar las identidades subversivas con el fin de enviarlas al margen y ponderar a las primeras como el único camino acertado para alcanzar la felicidad y el prestigio social. ${ }^{9}$

Ahora bien, después de este brevísimo recorrido teórico, quedan varias preguntas relacionadas con el título del presente trabajo: ¿cómo se vive la sexualidad en México? ¿Cuáles son los principales factores histórico-sociales que la forman y alimentan? Debe recordarse aquí el origen de la cosmovisión del cuerpo en la sociedad mexicana. No sólo se trata del fuerte choque entre culturas disímiles emanado de la Conquista durante el siglo XVI, sino de la existencia previa de culturas, sobre el actual territorio mexicano, donde cada una poseía una forma diferente de percibir el mundo y el cuerpo. No hay duda de que, luego de la llegada de los españoles, la cultura judeocristiana ha imperado apabullantemente en todo el país; no obstante, existen regiones con costumbres y sexualidades cargadas de

muy precisos que no permiten a los sujetos sociales moverse con libertad; sino por el contrario, los constriñen, dando poco margen a las posibles representaciones de algún tipo de diversidad o alteridad". Mauricio List Reyes, Jóvenes corazones gay en la Ciudad de México (Puebla: BUAP, 2005), p. 21. La sexualidad, elemento imprescindible y cuasi fundacional de toda sociedad, enfoca gran cantidad de las actividades realizadas por los individuos, ajustándolas a los parámetros intrínsecos de la misma. Esta situación resulta en un territorio bien delimitado de roles, donde los sujetos deben mantenerse para evitar cualquier tipo de sanción o atropello.

${ }^{9}$ Hasta aquí se ha venido apelando al papel legitimador de una sociedad heteronormada; no obstante, esta posibilidad de ponderación de una sexualidad hegemónica puede extenderse más allá de la condición heterosexual. Como se verá más adelante, las sexualidades de las culturas prehispánicas poseían también los mecanismos necesarios para establecer sus propios códigos sexuales. Así, una cultura determinada creará, según su sistema de creencias y valores, una sexualidad institucionalizada que permita o amedrente, según sea el caso, una serie de identidades. 
peculiaridades diversas, producto de sus anteriores concepciones. Por ello, el título del presente capítulo señala estos rasgos divergentes al no considerar el homoerotismo como una concepción única. A su vez, en este apartado se le dará un trato diacrónico para observar su revestimiento simbólico en los diferentes episodios históricos del país.

La homosexualidad ha sido un delito abigarrado en la cultura judeocristiana vertida sobre el territorio mexicano. Varios siglos antes de su llegada a América, el cristianismo en Europa había establecido dos caras para la sexualidad: la hegemónica y la marginal. Óscar Guasch, en su recorrido histórico por el "pecado nefando" de la "sodomía"10 en el contexto cristiano, señala cómo la homosexualidad fue desplazada del sitio de "tolerancia e indiferencia" que poseía en la sociedad romana, para ser trasladada a una orilla totalmente opuesta.

\footnotetext{
${ }^{10}$ La palabra "sodomía" -y su practicante denominado "somético", "sodomita" y "sodomético"- es un término de la tradición judeocristiana que ha perdurado durante largos siglos en la historia de Occidente. Su origen, como es bien sabido, está anclado en una interpretación del "Génesis" de la Biblia. La Iglesia Católica y otras religiones cristianas han utilizado dicho pasaje para constatar el castigo implantado por Dios hacia las personas con prácticas homoeróticas. No obstante, la pena impuesta a los "sodomitas" no tiene su origen en un acto sexual "contra-natura", sino en la violación de una norma de cordialidad: "La interpretación propagada por la Iglesia Católica afirma que los habitantes de Sodoma desean conocer (en sentido carnal) a los enviados del Señor y por ello son castigados. Sin embargo, un análisis riguroso del pecado de Sodoma revela que lo que se infringe realmente es la ley de la hospitalidad [...] El génesis no es el único lugar del Antiguo Testamento que condena el crimen de la ciudad de Sodoma, pero donde la violación de la ley de la hospitalidad parece más clara es en el Libro de la Sabiduría y en Ezequiel. En cualquier caso, lo cierto es que el recuerdo del pecado de Sodoma, reciclado y reinterpretado como pecado sexual, atraviesa la historia del Occidente cristiano durante los últimos quince siglos" Óscar Guasch, La crisis de la heterosexualidad (Barcelona: Laertes, 2000), pp. 42-43. Durante la Edad Media, el pecado de "sodomía" fue entendido de diversas formas -como el contacto entre personas de diferente sexo sin carácter reproductivo, la masturbación, el sexo oral o anal o ambos-, pero casi siempre señalaba el encuentro carnal entre individuos del mismo sexo. Generalmente, los códigos civiles de esta época estaban absolutamente impregnados de la pragmática religiosa y, por tanto, el "sodomita", en cualquiera de su formación social, fue duramente castigado y perseguido.
} 
Mucho se ha acusado al cristianismo como causante de la homofobia en Occidente; pero autores como John Boswell, ${ }^{11}$ Francis Mark Mondimore, ${ }^{12}$ Philphe Ariès, ${ }^{13}$ y el propio Guasch mencionan que, en las filosofías propagadas durante el Bajo Imperio Romano, estaba ya la gestación de un rechazo constante de una sexualidad asentada puramente en el hecho placentero, y este suceso coincidía con la propagación del cristianismo. Guasch también acota la figura del sodomita como "chivo expiatorio" de las autoridades establecidas poco antes de la caída del Imperio Romano y durante la Alta Edad Media. Al parecer, las medidas de control establecidas sobre los individuos gobernados o conquistados pugnaban por subyugar todas las actividades del hombre a partir de sus prácticas sexuales y organización de los roles genéricos: "En la Edad Media, la represión contra la sexualidades no ortodoxas se reactiva cada vez que se intenta establecer una autoridad y un poder centralizado". ${ }^{14}$

La mezcla de los poderes ideológicos, políticos y religiosos a fines del Imperio Romano produce entonces el rechazo a una sexualidad placentera y la circunscribe al hecho meramente reproductivo. El paradigma del sexo queda delimitado por un fuerte dispositivo de control con base en una justificación absoluta. No obstante, la "norma" no puede ser creada sin la figura borrosa de la disidencia. De este modo, si las autoridades eclesiásticas y políticas establecieron una sexualidad "natural", también crearon aquellas aberrantes y excluidas formas de contacto carnal entre los individuos. Está claro que si el objetivo de reproducción de la especie era anhelado por completo, al igual que la conservación de una estrategia de género inescrutable, la denigración de cualquier atentado contra las prácticas

\footnotetext{
${ }^{11}$ Cristianismo, tolerancia social y homosexualidad. Los gays en Europa occidental desde el comienzo de la Edad Cristiana hasta el siglo XIV, trad. de Marco-Aurelio Galmarini (Barcelona: Munchnik, 1992).

${ }^{12}$ Una historia natural de la homosexualidad, trad. de Mireille Jaumá (Barcelona: Paidós, 1998).

13 "San Pablo y (los pecados de) la carne" y "Reflexiones en torno a la homosexualidad" en Michel Foucault y otros, Sexualidades occidentales, trad. de Carlos García Velasco (México: Paidós, 1987).

${ }^{14}$ Guasch, La crisis de la heterosexualidad (Madrid: Laertes, 2000), p. 47.
} 
plausibles de la sexualidad se hallaba a la orden del día. Rápidamente, las formas “antinatura” de contacto sexual fueron conformadas para castigarlas por la vía legal y divina. Concilios y compendios de leyes sirvieron para fundamentar tal hecho. ${ }^{15}$ Papas y reyes, unidos por la defensa de la reproducción, arrasaron con sus preceptos las vidas de miles de sujetos cuyas prácticas sexuales no parecían del todo adecuadas al modelo instaurado.

Para arrancar de tajo lo indeseado, a lo largo de toda la Edad Media, el pecado de sodomía fue perseguido tanto por la Inquisición como por las reglas de convivencia social. El arraigamiento de la exaltación de una sexualidad ortodoxa con base en mandamientos divinos y legales impuso en los individuos un rechazo por cualquier manifestación heterodoxa de contacto carnal. La península Ibérica, por la fuerte presencia del catolicismo y su anterior pertenencia al Imperio Romano, fue devota fiel de los preceptos castigadores de cualquier detractor de la "sexualidad natural”. La sodomía fue quizás el pecado-delito, junto con la presencia del judío, que mayormente fue fustigada. Por ello, cuando se impuso el dominio ibérico en América, tanto sodomitas como judíos fueron tratados con los más hondos y sanguinarios castigos. El objetivo de crear una entidad social "pura", lo más cercana de los preceptos "divinos", en las tierras recién conquistadas impuso una estricta vigilancia de las normas genéricas, raciales y sexuales.

\footnotetext{
${ }^{15}$ Entre los mandatorios “civiles” están Justiniano, Carlomagno, Teodosio, Egica, Flavio Rescindo, entre otros. Por parte del clero, los diversos Concilios católicos han establecido numerosos principios para castigar el pecado del "sodomita". Puede observarse también que varias de estas leyes fueron creadas en tiempos de inestabilidad política o religiosa con el objetivo de constreñir las conductas de los creyentes o vasallos.
} 
Pero ¿cómo era visto el homoerotismo en las culturas nativas de América? Salvador Novo, ${ }^{16}$ Luiz Mott ${ }^{17}$ y Oswaldo Bazán ${ }^{18}$ han indagado en la existencia de una "homosexualidad"19 previa a la llegada de los españoles en las culturas americanas. Por razones culturales y nacionalistas, a lo largo del tiempo en México se ha concebido a la homosexualidad como un "vicio" propagado en el país por los extranjeros. De este modo, la "marginalidad sexual" es considerada un mal importado. Esta idea roba directamente al homosexual cualquier carta de ciudadanía nacional, para asimilarlo como traidor. El ensalzamiento de la patria no permite la disidencia sexual "propia" de las latitudes mexicanas, al contrario, las envía fuera de su territorio. ${ }^{20}$ Sin embargo, algo muy similar plantearon los españoles en sus primeros recorridos por América. Así, la existencia del "pecado nefando" 21 en la cultura propia sería negada: americanos y europeos enviarían esta culpa al contrario para verse libre de cualquier desliz sexual y genérico. ${ }^{22}$ Novo, Mott y Bazán

\footnotetext{
${ }^{16}$ Las locas, el sexo y los burdeles (México: Diana, 1979).

17 "Etno-historia de la homosexualidad en América Latina", trad. de Libia J. Restrepo, en Historia y sociedad (Bogotá: Universidad Nacional de Colombia: 1997), no. 4, pp. 123-144. [Anotar otros textos que incluyan a México]

${ }^{18}$ Historia de la bomosexualidad en la Argentina (Buenos Aires: Marea, 2006).

${ }^{19}$ Colocar la palabra homosexualidad entre comillas para hablar del homoerotismo en las culturas prehispánicas tiene como fin señalar que dicho comportamiento sexual no correspondería con la concepción del binomio heterosexual/homosexual que en la actualidad se tiene. Las culturas americanas antes de la llegada de los europeos poseían códigos sexuales y de género con revestimientos simbólicos diferentes.

${ }^{20}$ Novo relata, con su fina y excelente ironía, cómo durante la Noche Triste los aztecas ofendían a los invasores: "Al perseguir a los españoles, los mexicas les gritaban Cuiloni, Cuiloni. A esta distancia es imposible saber si les sabían algo o se los decían al tiro; pero consultados los más fehacientes Vocabularios, hallamos que cuiloni quiere decir puto o "somético», si la verdad, aunque no peque, incomoda." El supuesto rechazo de los aztecas hacia el "somético" es un hecho no delimitado del todo: algunos autores los señalan de sancionar terriblemente la homosexualidad, otros, por el contrario, los califican de una actitud indiferente respecto de los actos homoeróticos. Más adelante se hablará sobre esta añeja cuestión.

${ }^{21}$ Bajo el nombre de "pecado nefando" los españoles entendían las relaciones sexuales "contranatura"; sin embargo, el mismo término designaba, algunas veces, otros delitos de índole religiosa como la herejía, el semitismo y, en general, la práctica de cualquier otra creencia diferente a la católica.

${ }^{22}$ El exilio de la cultura nacional ha provocado en los sujetos "marginados" la creación de una pertenencia con base en el rasgo "peyorativo" de su condición excluida. Ejemplo de ello es la comunidad judía y los disidentes sexuales: ambos grupos arguyen la calidad de su transgresión como una segunda
} 
documentan y analizan el panorama y establecen cómo una cultura extraña -la española-, con una carga homofóbica indisoluble, observa al sodomita americano con terror y, de paso, justifica su estrategia de conquista en un precepto religioso.

Osvaldo Bazán, en la introducción hecha sobre el homoerotismo en la América prehispánica a su Historia de la homosexualidad en Argentina, relata cómo la mayor parte de las culturas nativas del continente asimilaban la "homosexualidad" como un hecho cotidiano y "natural": desde Norteamérica hasta Tierra del Fuego, el homoerotismo aparece sin aspavientos. Resulta entonces más difícil hallar culturas sancionadoras de esta sexualidad por el gran número de grupos humanos donde ocurría de forma permisiva e indiferente. ${ }^{23}$

Luiz Mott estudia con detenimiento las crónicas de los conquistadores de la actual Iberoamerica y describe cómo los españoles y portugueses señalaron con vehemencia destructiva al sodomita indiano: "Ya Hernán Cortés, en su primera Carta de Relación, enviada al emperador Carlos V en 1519 decía: 'Hemos sabido y sido informados de cierto que todos [los indios] de Vera Cruz son sodomitas y usan aquel abominable pecado'. López de Gómara añade que los nativos del río Pánuco y adyacentes eran 'grandísimos putos'”. ${ }^{24}$ Es visible el enfrentamiento de una cosmovisión española -cegada por su enclaustrada visión de la sexualidad- contra la de las culturas nativas, cada una con formas de aprehensión

\footnotetext{
"patria". De tal suerte, resulta una doble nacionalidad expresada en la bandera gay, reconocida internacionalmente -cada sujeto identificado con dicho símbolo accede, independientemente del lugar donde se encuentre, a un espacio familiar y amistoso-, y con la adhesión a una comunidad judía hermanada por sus rasgos culturales y religiosos. Queda entonces una doble pertenencia: por un lado se puede ser mexicano y judío o, en su caso, argentino y homosexual, la primera denominación señala su sitio de nacimiento, pero la segunda refiere su característica de identidad que ubica al individuo en una situación marginal respecto de una sociedad hegemónica.

$23 \mathrm{Al}$ respecto, Luiz Mott organiza una lista de los grupos humanos americanos donde el homoerotismo saltaba a la vista. En lo que concierne a México, el investigador anota los siguientes lugares y culturas: "Albardaos, Cipacingo, Itza, Jaguaces, Pánuco, Sonora, Tabasco, Tahus, Tlasca, Yucatecas, Mayas y Aztecas.” Mott, "Etno-Historia de la homosexualidad en América Latina”, p. 131.

${ }^{24}$ Mott, "Etno-historia de la homosexualidad en América Latina”, pp. 127-128.
} 
diversas del sexo y el cuerpo. No obstante, el "sodomita" servía indudablemente para justificar una intromisión en América: si los indígenas estaban embriagados por el "vicio nefando", era necesario, para su correcta intromisión en el orden divino, una corrección de sus "abyectas conductas" y garantizar su salvación. ${ }^{25}$ Así, los "grandísimos putos” debían ser aniquilados por el poder político y religioso para el establecimiento de un sistema de género y sexual en concordancia estricta con la norma católica y social. Aquí empieza una larga serie de torturas y asesinatos masivos realizados por los primeros españoles y, posteriormente, por el aparato de la Inquisición.

Pero antes de continuar reflexionando sobre el encuentro entre españoles e indígenas al respecto de la "sodomía", será preciso abordar un poco más la cuestión del homoerotismo en las culturas prehispánicas de México. Retomando a Luiz Mott, es posible decir que los datos más cercanos sobre la "homosexualidad" en América los brindan los cronistas europeos. Ejemplo de esto es el texto citado de Cortés, quien informa al monarca sobre la presencia de la sodomía en tierras mexicanas. Por ello, los registros encontrados sobre una sexualidad homoerótica en el México prehispánico saltan a la vista no sólo en Cortés, sino en Fray Bernardino de Sahagún -Historia general de las cosas de la Nueva España-, Bernal Díaz del Castillo -Historia verdadera de la Conquista de la Nueva España-, Francisco

\footnotetext{
${ }^{25}$ Sobre la "sodomía" como pretexto de la Conquista, José Luis Trueba Lara acota lo siguiente: "Las palabras de Cortés [al respecto de la "homosexualidad" en tierras mexicanas] no pueden leerse como un simple encuentro o una mera noticia; en ellas se ocultan -cuando menos- dos actitudes que merecen ser destacadas: una excusa para la guerra justa en contra de los naturales del Nuevo Mundo y un señalamiento de las bajezas de sus pobladores que los sitúan en una posición de inferioridad. Efectivamente, la homosexualidad -junto con otras prácticas sexuales y religiosas- se convirtió en fundamento legal [y religioso] de la Conquista, justo como lo señala Juan Ginés de Sepúlveda en su Tratado sobre las justas causas de la guerra contra los indios." José Luis Trueba Lara, Historia de la sexualidad en México (México: Grijalbo, 2007), pp. 208-209.
} 
López de Gómara ${ }^{26}$-Conquista de México. Historia general de Indias- y Álvar Núñez Cabeza de Vaca -Naufragios. Los cronistas ibéricos no dudan en contar con denotado asco los encuentros homoeróticos entre los "indios" y, sobre todo, parecen encontrarlos con frecuencia en las tierras cálidas cercanas a las costas. Al respecto, Novo no escatima en ironía y menciona: "Costas y tierra caliente. He aquí, pues, el antiguo pedigree de los carnavales en Veracruz, y de los atractivos turísticos de Acapulco". ${ }^{27}$ Pareciera que la "sodomía" vista por los españoles radicaba cercana a los climas tropicales por el supuesto rechazo hacia el "homosexual" en el Valle de México. Novo describe las condenas y castigos perpetrados sobre los "sométicos" por instrucciones de Nezahualcóyotl: "por su severa, morigerada, tezcocana parte, incluye (según su descendiente, el historiador don Fernando de Alva Ixtilxóchitl) como la decimotercera de sus Ordenanzas una que manda: 'Que si se averiguase ser algún somético, muriese por ello’."28 Y, más adelante, menciona:

Pero, de creer a Torquemada (Monarquía Indiana, Libro II, Cap. III), Neza era más sádico de cuando lo protege su descendiente [Alva Ixtlixóchitl] cuando se trataba de moralizar a Tezcoco con desmoralizar o atemorizar a las locas: distinguía entre ellas y sus mayates, y les asignaba diversos castigos: al "Paciente" le sacaban los intestinos por aquel conducto que solía servirle de sexo; lo enterraban luego en ceniza, y los muchachos del lugar se divertían en echar leña seca para que pudiera mejor arder con todo y loca destripada. Al mayate o agente, simplemente lo enterraban en ceniza hasta que exhalara el último aliento o Ohuaya, que es como, según los filólogos, decían, ¡ay!, los nahuas. ${ }^{29}$

\footnotetext{
${ }^{26}$ Cabe resaltar que López de Gómara jamás pisó suelo americano: sus crónicas fueron escritas a través de lo leído, escuchado e imaginado sobre México y "Las Indias". Por ello, la presencia en su obra de juicios subjetivos sobre las costumbres "satánicas" de los nativos se presta a una mayor dubitación.

${ }^{27}$ Salvador Novo, Las locas, el sexo y los burdeles, p. 55

${ }^{28}$ Loc. cit.

${ }^{29} \mathrm{Ibid}$., p. 250.
} 
Llama la atención que el castigo indígena contra los "sométicos" es igual de atroz que el propagado por los ibéricos durante sus primeros recorridos por América cuando observaban algún "vicioso nefando". 30

Ahora bien, ¿cuál es la relación de verosimilitud entre Ixtlixóchitl y la realidad del "somético" tezcocano, si el primero parte de una cosmovisión ya impregnada de los valores sociales y católicos españoles? ¿Cabría la posibilidad de dudar al respecto de lo leído si el desprecio por el "sodomita" era sitio ineludible en la educación adquirida por Ixtlixóchitl? Sobre esto, Bazán menciona que "para algunos investigadores actuales, Fernando de Alva, un mestizo educado por españoles, insistió siempre en dar versiones occidentalizadas de la vida náhuatl”. ${ }^{31}$ La principal confusión planteada por Bazán, al respecto del homoerotismo entre los mexicas, radica en el acérrimo castigo dictaminado por Nezahualcóyotl y las visiones de indiferencia hacia la sodomía advertidas por Bernal Díaz del Castillo. Lo mismo plantea Mott en relación con los cronistas: "En cuanto a los aztecas, hay una clara contradicción entre los primeros observadores, Díaz del Castillo los señala como grandes amantes del homoerotismo, mientras que el franciscano fray Bernardino de Sahagún los exime de esta abominación". ${ }^{32}$ La paradoja se extiende cuando el mismo Sahagún describe los usos del tzictli (chicle) entre las mujeres y los hombres. Para las primeras, su uso tenía fines de higiene bucal; mientras que, para los últimos, el chile denotaba su predilección por el "vicio nefando". Citado por Bazán, Sahagún describe el uso del "chicle somético" de la

\footnotetext{
${ }^{30}$ Bazán realiza un puntual recorrido por las crueldades ibéricas contra el "sodomita" indiano. El investigador argentino menciona cómo Vasco Núñez de Balboa, en su itinerario por Centroamérica, realiza una serie de crímenes con gran lujo de violencia contra los "sométicos" de dicha región. El más famoso de ellos es cuando Núñez de Balboa arroja sus perros sobre cincuenta "sométicos" para que fueran devorados vivos. Historia de la homosexualidad en la Argentina, pp. 18-28.

${ }^{31}$ Ibid., p. 33.

32 Mott, "Etno-historia de la homosexualidad en América Latina", p. 128.
} 
siguiente forma: "Los hombres también mascan el tzicli para echar también reuma y para limpiar los dientes, empero házenlo en secreto. Y los que son notados de vicio nefando, sin vergüenza lo mascan, y tiénenlo por costumbre andarlo mascando en público; y los demás hombres, si lo mezmo hacen, nótanlos de sodométicos". ${ }^{33}$

¿Cómo queda entonces la cuestión sobre el homoerotismo entre los mexicas? ¿La "homosexualidad" era un hecho permitido o se castigada a sus practicantes? Probablemente, las leyes instauradas contra el "sodomita" por Nezahualcóyotl tuvieron gran eco en el Valle de México, pero ¿cómo se explica la presencia notable de "homosexuales” en las crónicas? Debe tomarse en cuenta aquí la fecha de contacto entre españoles y mexicas (1517) y la referida a la muerte de Nezahualcóyotl (1472): en los casi cincuenta años de diferencia entre ambos sucesos pudieron haber ocurrido cambios en las costumbres sexuales que, quizás, hicieron más laxas las normas instaladas al respecto entre los habitantes del Valle de México. También, como se mencionó anteriormente, la exageración de los cronistas sobre el homoerotismo en dominios aztecas conduce a esta paradoja. La duda queda abierta, pero no puede negarse la existencia de la "homosexualidad" entre los mexicas: un castigo -como los dictados por Nezahualcóyotl y los acotados por Sahagún- o la indiferencia ante el acto señalada pródigamente por algunos cronistas- confirman el hecho.

Una vez consumada la Conquista, es evidente el cambio radical sufrido por los habitantes del actual territorio mexicano. Cosmovisiones y costumbres fueron cortadas de tajo, mientras otras quedaron mezcladas con la visión europea del orden colectivo. En cuanto a la sexualidad, la imposición de un sistema jerárquico absoluto -y "natural"- del género y la raza trajo consigo la inalterabilidad de los principios planteados sobre el contacto erótico.

\footnotetext{
${ }^{33}$ Bazán, Historia de la homosexualidad en la Argentina, p. 34.
} 
El paradigma sexual es por completo modificado y las relaciones "contranatura" son suprimidas al instante. Inicia así una Nueva España profundamente católica y vigilada al extremo por el aparato de la Inquisición -fundado por cédula real en 1569-. Así, la norma judeocristiana, con más de mil años de tradición, cobra gran brío en tierras americanas; no obstante, el deseo es irrefrenable y, por más órdenes impuestos al cuerpo, la satisfacción siempre es buscada con avidez y, en este caso, mucha cautela.

El nuevo paradigma de la sexualidad instaurado en la Nueva España se propagó no sólo en la reglamentación jurídica y religiosa, sino en la visión tenida acerca del cuerpo por cada sujeto. La vigilancia respecto de la correcta aplicación del sistema genérico y sexual era llevada a cabo tanto por la Inquisición como por los individuos ajustados a dicha norma. El desprecio hacia el "sodomita" es palpado en la mentalidad novohispana a cada paso, y se revela en los terribles castigos impuestos a los practicantes del homoerotismo. Sin embargo, dadas las caracterizaciones jerárquicas de la penetración, el pasivo o receptor en la relación "contranatura" resultaba -y resulta- el más odiado. En la historia de la sexualidad judeocristiana, ${ }^{34}$ siempre el activo ha gozado de mayor clemencia e "impunidad" con respecto al sujeto que es penetrado. Claro está que esta situación se funda sobre la idea del pasivo como sujeto transgresor de su género y su sexualidad por ocupar el "lugar de la mujer"

\footnotetext{
${ }^{34}$ El sujeto "pasivo" en el acto homoerótico ha estado ligado siempre a una situación de marginalidad absoluta. El carácter misógino de la mayoría de las culturas occidentales ha rechazado por completo la asimilación de un hombre con el ámbito de lo femenino. A su vez, dada la extrema genitalización del encuentro erótico en el revestimiento simbólico de la sexualidad, la penetración distribuye, de forma absoluta, el poder entre los practicantes del coito. Para el "penetrador" queda una carga cultural de jerarquía en cualquier caso; por el contrario, el "penetrado" siempre estará, culturalmente, en una situación de desventaja con su entorno -máxime si se trata de un hombre que ha renunciado a su "sustancia viril". Incluso, en civilizaciones como la griega y la romana, tan permisivas en cuestiones homoeróticas, hay un dejo de cierto "desprestigio" hacia el "penetrado" por su posible parentesco con lo "mujeril". Por ello, en dichas culturas, el "activo" siempre debía poseer un estatus de superioridad con respecto al "pasivo", como una mayor edad o condición social; la crítica estaba orientada contra aquellos que hacían de "pasivos" en el acto sexual con personas de menor rango.
} 
en el acto sexual. De este modo, el receptor denigra el "orden natural" y la condición masculina al integrarse dentro del ambiente de lo femenino. ${ }^{35} \mathrm{El}$ odio contra la mutación de género y la disidencia de la sexualidad hegemónica aparecen aquí en todo su esplendor, y la mentalidad de la Nueva España no escapó a dichos preceptos, quedando impregnado tal hecho hasta la cosmovisión actual de la sexualidad en México. ${ }^{36}$

La Inquisición entonces hizo gala de sus aparatos de tortura para acabar con todos aquellos sujetos indeseados en el interior del orden social. Su eliminación de lo "abominable" asesinó y aplicó diversos suplicios a los detractores de la norma religiosa, entre ellos a los sodomitas. El caso más conocido del orden inquisitorial novohispano contra los disidentes sexuales fue el de 1658, cuando varios individuos fueron quemados para "purificar" la tierra de su aborrecible pecado. ${ }^{37}$ Novo lo refiere del siguiente modo:

Pero en el siglo XVII tiene que haber sido del cocol la movida, la onda o como se le quiera o deba llamar, con la Inquisición por mayor amenaza que hoy el charolazo del seudoagente. Y sin embargo, o para expresarlo con mayor dramática elegancia: eppur si mouve. El martes 6 de noviembre de 1658 a las 11 horas del día, "sacaron de la real cárcel de esta corte a 15 hombres, los 14 para que muriesen quemados, y el uno, por ser muchacho, le dieron 200 azotes y [fue] vendido a un mortero por seis años; todos por

\footnotetext{
${ }^{35}$ Más adelante se verá la existencia de dos sistemas de visión de la homosexualidad: el mediterráneo y el norteamericano. En el primero, el sujeto "activo" nunca perderá su carácter viril y será aceptado socialmente. En el segundo, serán considerados como "homosexuales" todos los individuos que intervengan en el encuentro homoerótico. Por razones históricas, económicas y sociales, las zonas urbanas de México son más proclives al sistema de deseo norteamericano, mientras las rurales están más cercanas a una representación erótica mediterránea.

${ }^{36} \mathrm{El}$ desprecio por el afeminamiento y el "homosexual" es un hecho muy arraigado en la mentalidad del mexicano. Lamentablemente, la aprehensión de la norma ha producido una homofobia internalizada en los propios disidentes sexuales, al grado de rehuir al más "obvio" o evitar una cercanía con el "travestido", por sólo citar algún ejemplo.

${ }^{37}$ Dado que los límites de la Nueva España abarcaban Centroamérica hasta la actual Costa Rica, es necesario señalar la existencia de "siete casos de sodomía en Guatemala" hacia 1548, en los cuales participaron integrantes de la misión evangelizadora e indígenas. Mott, "Etnohistoria de la homosexualidad en América Latina”, p. 133.
} 
haber cometido unos con otros el pecado de Sodomía [sic], muchos años había, así residiendo en esta ciudad donde tenían casa con todo aliño donde recibían y se llamaban por los nombres que usan en esta ciudad las mujeres públicas, así de rengue como de aire: como estando en la ciudad de Puebla de los Ángeles. Fue el principal actor de este pecado un mulato que andaba en traje de indio, llamado COTITA DE LA ENCARNACIÓN, que era el más aseado y limpio, y gran labrandero y curioso; y éste, desde edad de siete años se dio a este vicio, y su aspecto al presente era de más de 40 años; y ajusticiaron entre ellos a un fulano Correo, mestizo, que hacía 47 años que lo usaba, y a un español llamado [en blanco el nombre] natural de esta ciudad. Era el padre de todos, y a quien ellos llamaban Señora la Grande, y servía de escudero; avisando un día a unos y otro a otros para que se apercibiesen de recibir la visita, y era el que los concertaba, y después de la merienda los ponía en los puestos unos con los otros para ejecutar este pecado con toda liviandad. Y él usaba en todas ocasiones, tiempos y lugares...”38

Como es posible advertir, el "vicio nefando" era muy practicado mientras no fueran sorprendidos los actores del mismo. "Cotita de la Encarnación" ejemplifica este acontecimiento con sus casi treinta y tres años de labores ininterrumpidas al servicio de la disidencia sexual, al igual que "Señora la Grande", decana de la "sodomía" novohispana.

Luego del caso señalado, hubo otro similar en 1673. Se trataba ahora de "siete mulatos, negros y mestizos de Mixcoac", quienes fueron quemados por sus prácticas de "sodomía". Al parecer, el castigo de "Cotita" y "Señora la Grande" pudo menos como ejemplo que la necesidad erótica de los inculpados y, seguramente, debieron haber existido más casas de homosexuales durante el periodo inquisitorial en México, donde los prestadores de servicio y los clientes aseguraban su placer al amparo de los muros virreinales. Además, como menciona Mott en su artículo, México y Brasil son los países de donde más se reportaron casos de disidencia sexual durante la Colonia. Asimismo, el investigador señala

\footnotetext{
${ }^{38}$ Novo, "Las locas y la Inquisición”, p. 252.
} 
la existencia de más casos de "sodomía" documentados por el aparato inquisitorial de ambas naciones, pero que "lamentablemente aún no ha sido realizado un inventario de todos los sodomitas latinoamericanos prisioneros y procesados por estos tribunales de la Santa Inquisición". ${ }^{39} \mathrm{El}$ mismo autor señala el nacimiento de una "subcultura gay" en Brasil durante el periodo colonial. ${ }^{40}$ Esta afirmación, por lo dicho al respecto de la abundancia de casos inquisitoriales contra la sodomía en la Nueva España, puede ser aplicada en el caso mexicano e, incluso, en otras zonas de América Latina más alejadas de la supervisión del aparato legal y religioso de la Colonia. La situación se debe a la presencia de grupos "marginales" -judíos, protestantes y, por supuesto "sodomitas"-que, de manera subrepticia, fueron llegando a la América colonial con el objetivo de iniciar una nueva vida, alejados ya de las persecuciones sufridas en Europa. Por estos asuntos, de índole político-religiosa, la Inquisición busco a toda costa juzgar a los pecaminosos y abatirlos al instante. Sin embargo, está claro que, los practicantes de "conductas inapropiadas", buscaron los medios necesarios para guarecerse de tan fiero ataque, permaneciendo en una continua ocultación.

El artículo citado aquí de Luiz Mott, si bien informa abundantemente de la homosexualidad en la América Latina colonial, está focalizado en su mayoría sobre Brasil. El autor se dio a la búsqueda y rescate de los textos inquisitoriales de su país y acota que, por no haberse instalado en ese territorio un aparato inquisitorial como el de México, Lima o Cartagena, había visitaciones realizadas periódicamente por el Santo Oficio de Lisboa. Entre los archivos de dicha organización,${ }^{41}$ Mott halló el caso de dos mexicanos acusados de

\footnotetext{
${ }^{39}$ Mott, “, "Etno-historia de la homosexualidad en América Latina”, p. 133.

${ }^{40}$ Ibid., p. 136.

41 "Después de un benedictino levantamiento de más de cuatro mil denuncias y 400 procesos de sodomía archivados en la Torre del Tombo de Lisboa, localizamos hasta el presente 283 denuncias de brasileños o portugueses residentes en el Brasil, infamados de practicar el pecado de Sodoma", Mott, "Etnohistoria de la homosexualidad en América Latina”, pp. 134-135.
} 
sodomía en el siglo XVII: Bartolomé Martínez de Mora y Pedro Medina, ambos aprehendidos en Portugal por dedicarse a mantener contacto carnal con personas de su mismo sexo. El primero, además, es acusado de "cristiano nuevo" y de profesar en secreto el judaísmo. ${ }^{42}$ Martínez de Mora reconoce, ante el tribunal de la Inquisición, haber residido en la Ciudad de México y en Veracruz -Novo no se equivocaba sobre el pedigree homoerótico de la costa-. Por su parte, Pedro Medina, resultó un viajero conocedor de lugares en ese momento sumamente exóticos -India, China, Filipinas, Persia y Ceylán- que, lamentablemente, fue entregado por su apasionado amante ${ }^{43}$ a la Inquisición portuguesa. Estos dos casos acaban por confirmar la presencia de un fuerte homoerotismo en la Nueva España a pesar de las represiones sociales, legales y religiosas. Así, la fuerza del deseo aparece en todo su esplendor, reclama su entera satisfacción y poco le importa la mordaza impuesta a la sexualidad.

El gueto novohispano estaba directamente enfrentado con la Inquisición y con los procedimientos jurídicos del fuero civil. De este modo, tenía -aparte del intrínseco rechazo inculcado en la mentalidad colonial- dos fuertes enemigos de quienes ocultarse. Sin embargo, con la extinción del Santo Oficio en México, hacia 1820, las conductas sociales y sexuales de los individuos de la naciente nación mexicana quedan, enteramente, a cargo del aparato legal. Al respecto, Monsiváis menciona: "Si en el Virreinato se condena a los sodomitas a la hoguera, porque 'mudan de orden natural', en el siglo XIX casi nunca se les

42 Aquí resalta, nuevamente, la "sodomía" como chivo expiatorio utilizado para acusar al sujeto opuesto a la religión, la clase o la cultura.

43 "Después de tantas peripecias, al llegar a Lisboa es denunciado al Santo Oficio por un joven de 20 años, Manuel Rois, igualmente ex prisionero de los bátavos. Según este joven, en los seis meses en que estuvieron bajo el yugo de los calvinistas, mantuvieron más de 120 cópulas sodomíticas, ' «metiendo su miembro viril y derramando simiente en el vaso trasero de él, confesante, y con consentimiento de él, cometieron otras 80 veces el nefando pecado de sodomía, siendo Pedro Medina el paciente.»" Ibid., p. 139. 
menciona por escrito, en apego a la consigna del no decir para no propagandizar" ${ }^{44} \mathrm{La}$ sociedad mexicana continúa guardando enormes resabios de su predecesora la novohispana; aunque la Independencia haya consumado la separación de México respecto del gobierno Español, resulta difícil arrancar de tajo costumbres arraigadas durante trescientos años. La cosmovisión mexicana nace heredera de las pautas de comportamiento coloniales y las continúa impulsando durante largo tiempo. Si bien las nuevas ideologías, provenientes de Francia y los Estados Unidos, proveen al mexicano de otras formas de concebir el orden político y religioso, la sociedad en su conjunto se muestra recelosa de modificar las normas ya convenidas e inculcadas desde hace siglos. Así, el aparato inquisitorial ha desaparecido, pero no el dispositivo de control implantado en la mentalidad de sus habitantes que ha sido transmitido por generaciones.

La sexualidad disidente, proscrita totalmente en la Colonia, es un tema absolutamente tabú sobre el que nadie intenta echar claridad. El nuevo orden social decimonónico surge arraigado a un esquema sexo-genérico judeocristiano, donde el sodomita no tiene cabida alguna. Al contrario, en la construcción de la nación mexicana se pondera una sexualidad con base en un hermético sistema de género binario: masculino/femenino. La premiación y exaltación de la virilidad es requisito indispensable para una adecuada incorporación al aparato social. Por su parte, el ámbito de lo femenino es resguardado en la figura del "ángel del hogar", la tierna mujer forjadora de los hijos a quien poco le interesa el sexo y, mucho menos, el mundo de la política. Vulnerar estos límites es un delito y significa el rechazo y la burla absoluta: el Estado no asesina a los infractores del sistema sexo-genérico, pero los ignora dejándolos a merced de la "homofobia", ante la cual su destrucción está garantizada

\footnotetext{
${ }^{44}$ Carlos Monsiváis, Que se abra esa puerta. Crónicas y ensayos sobre la diversidad sexual, pról. de Alejandro Brito (México: Paidós/Debate feminista, 2010), p. 78.
} 
por un fuerte entramado de relaciones simbólicas: "El siglo XIX en México es tiempo de la construcción de lo nacional, y lo normativo se desprende de algo tan difuso como el catálogo de virtudes cívicas. [...] Entonces, el pecado nefando contradice a tal punto 'la esencia' de los mexicanos que no se admite por escrito, y se le deja a la cultura oral el castigo al marica, el monopolista de los agravios contra la masculinidad". ${ }^{45}$

Las nuevas leyes se crearon con base en un Código Napoleónico que despenalizaba la sodomía; no obstante el ambiente de rechazo persistió con audacia en las generaciones de la joven nación. El "sodomita" desaparece y cede el paso a las llamadas "faltas a la moral", donde tienen cabida las sexualidades disidentes que son advertidas por el aparato judicial. ${ }^{46}$ Los nuevos términos usados para describir al antiguo "sodomita" son, ahora, el "afeminado", el "joto" y el "invertido", entre otros más de amplio arraigamiento. Hay un deseo recóndito de circunscribir el peso del delincuente únicamente al ámbito de lo legal, por ello suena ya un tanto anacrónico el término "sodomita" en el intento de modernización de la nación mexicana. Sin embargo, el peso de la Iglesia Católica y sus normas acerca del uso del cuerpo son de gran influencia aún para buena parte de la colectividad y, por ende, del Estado. Debe recordarse aquí la fuerte vinculación entre ambos sectores hasta la década del cincuenta del

\footnotetext{
${ }^{45}$ Monsiváis, Que se abra esa puerta, p. 52.

$46 \mathrm{Al}$ respecto, Monsiváis menciona: "Desde la adaptación en el México del siglo XIX del Código Napoleónico, al no prohibirse explícitamente la homosexualidad consensuada entre adultos, las leyes en México la autorizan. (Algo muy distinto sucede con la paidofilia, altamente penada para heterosexuales y homosexuales.) Esto no evita la persecución despiadada de los disidentes, los safaris en pos de maricones justificados por un recurso legaloide ya omnipresente a fines del siglo XIX: "Faltas a la moral y las buenas costumbres", expresión ajustable por entero a los criterios del agente del Ministerio Público o del juez o de los policías encargados de las detenciones. Basta mencionar la "conducta aberrante" y para que no se discutan las multas, los arrestos por quince días o por varios años, los envíos al penal de las Islas Marías por el solo de delito de la voz y la apariencia, los maltratos, los chantajes policiacos, la indiferencia complacida ante los crímenes de odio contra los homosexuales. Agréguense a esto en primer plano las condenas reiteradas de la iglesia católica y la excomunión de facto a los que viven en pecado nefando." Ibid., pp. 144-145.
} 
siglo XIX, cuando se realiza el proceso de desvinculación entre ambos sectores y surge el Estado laico, producto de la Constitución de 1857.

El imaginario de la sexualidad decimonónica queda plasmado en la literatura de ese tiempo. La mayoría de los autores del siglo XIX dibujan las bases de una sociedad mexicana adecuada y moralizan sobre conductas poco adecuadas. Los elogios hacia la virilidad y la imagen de la mujer consagrada al espacio privado son constantes. Es relativamente escasa la representación del "afeminado" o "invertido" dentro de este corpus literario, mucho menos la afirmación directa de una sexualidad disidente. Los ojos de los lectores podrían horrorizarse ante semejante desacato y, por tanto, la representación de la homosexualidad como tal es relativamente nula. No obstante, hay ciertos textos donde se alude de forma directa a la inversión de los roles genéricos y, de algún modo, a una representación homoerótica. Tal es el caso de la presencia de una mujer travestida en "Manolito el pisaverde" (1938) de Ignacio Rodríguez Galván. ${ }^{47}$ Este cuento ofrece pasajes verdaderamente homoeróticos ${ }^{48}$ conjugados con una transgresión total del espacio de la mujer. La protagonista, María, decide cambiar su indumentaria femenina por una masculina para ingresar a la sociedad mexicana y encontrarse con su amado. La historia es un tanto "desajustada" para su época, puesto que María se arriesga en un aventurero viaje de Guatemala a la Ciudad de México en búsqueda de su novio, José Almaraz, quien la había abandonado meses antes en su afán de hallar fortuna en suelo mexicano.

\footnotetext{
${ }^{47}$ Ignacio Rodríguez Galván, Manolito el pisaverde y otros cuentos, pres. de Ignacio Trejo Fuentes (México: Premiá, 1984), pp. 36-37.

${ }^{48}$ El texto de Rodríguez Galván será analizado con mayor detenimiento en el capítulo dedicado a los antecedentes del homoerotismo en el cuento mexicano, por ello la referencia aquí será breve y meramente informativa.
} 
El travestimiento de María para convertirse "Manolito" es todo un éxito: su andrógina belleza y carisma delicado cautiva a hombres y mujeres por igual. Si bien el lector sabe que la protagonista es una mujer, los personajes masculinos desconocen tal hecho y se dirigen a ella -él- con afanes eróticos. Muchos de los hombres asistentes al baile no dudan en mostrar su afecto a Manolito al grado de acosarlo por su hermosura casi femenina. ¿Qué es lo que sucede en el texto? ¿No hay acaso un denodado interés por mantener un contacto homoerótico con Manolito? La respuesta está en las siguientes líneas del cuento: “-Vístase usted de mujer -dijo otro-, y por vida mía que nos casamos mañana. -iCuántos te envidiarían una muchacha tan linda! -Por las pezuñas de Satanás, que me dan ganas de arrancarle ese bigote que está deshonrando -dijo un militar alto y grueso, y al mismo tiempo llevó su mano al rostro de Manuel". 49

El atractivo de Manolito no es la única exhibición de disidencia sexual presentada por la literatura mexicana decimonónica. José Ricardo Chaves señala la presencia de otros personajes correspondientes al estereotipo del "afeminado", cuya presencia denota una muy directa alusión al viejo "sodomita" novohispano, pero con un pie ya en la versión médicolegal del "homosexual" de finales del XIX y principios del XX. Chaves advierte que estos personajes con características propias del "sexo opuesto" son hombres con pocos -o nulosdeseos de crecer:

Buena parte de esta disminución de la masculinidad, de este aniñamiento, se da desde los nombres de los personajes, generalmente con diminutivos o bien coloquiales: Manolito, según vimos en el cuento de Rodríguez Galván; Josecito [y don Francisco], en El fistol del diablo (1845-1846), de Manuel Payno (1810-1894), Pablo y Chucho el Ninfo, en José T. de Cuéllar, por ejemplo. Por su preocupación excesiva

\footnotetext{
${ }^{49}$ Ibid., p. 38.
} 
por sí mismo, por su imagen, parecen narcisos que no quieren (o no pueden) crecer, que se encuentran estancados en una etapa de infancia o adolescencia, lo que nos remite a la interpretación freudiana de la homosexualidad. ${ }^{50}$

Las novelas mencionadas por Chaves colocan a los "hombrecitos" como el lugar negativo de la virilidad. Es más, ni siquiera podría tratarse de entes masculinos, son, más bien, sujetos con una representación escasa de "hombría" y, por tanto, caen dentro del soslayado ámbito de lo femenino. Así, el aniñamiento remite a la visión de un sujeto masculino a medio terminar, con una profunda carga peyorativa, y es, por si fuera poco, un ser inútil a la patria en formación. La nación mexicana poco necesitaba de "hombrecitos" sin deseos de procrear o absortos en el cuidado de su persona. Al contrario, solicitaba de la presencia de "hombres" socialmente construidos para emprender un proyecto de país acorde con la cosmovisión nacional.

Josecito y don Francisco son señalados por un profundo apego al cuidado personal. Su bella figura es parte imprescindible de su persona y buscan conservarla a toda costa. Hacen uso de los más sofisticados cosméticos y de diversos trucos de ropa para mantener siempre lozana su belleza. Y aunque su deseo sexual aparece orientado hacia las mujeres, sus actitudes delatan un fuerte afeminamiento de su persona.

Esta situación se repite en la Historia de Chucho “el Ninfo” (1871), de José Tomás de Cuéllar. El texto es, para muchos críticos interesados en la literatura de corte homoerótico, la primera novela gay mexicana. La afirmación, sin duda, es demasiado fuerte, pero no dista

\footnotetext{
${ }^{50}$ José Ricardo Chaves, “Afeminados, hombrecitos y lagartijos”, en Miguel Capistrán y otros, México se escribe con J. Una historia de la cultura gay, pról. de Luis Zapata (México: Planeta, 2010), p. 74.
} 
mucho de la realidad del texto. Chucho resulta un cuidado acercamiento al afeminado decimonónico y muestra, para el aprendizaje de sus lectores, lo que no debe ser un "hombre".

La novela hace un recorrido por toda la vida de Chucho: desde su nacimiento hasta su adultez, cuando el personaje adquiere - deus ex machina- la glorificada virilidad. Para contar la vida de Chucho, el narrador despliega todo un discurso simbólico sobre las construcciones de género, la familia y, por ende, la patria. Así, la "inversión" o falta de masculinidad del protagonista es debida a una sobreprotección materna por la ausencia de la figura del padre. La visión de madre consentidora al extremo del hijo único, sin el sostén del ente patriarcal, es duramente criticada por el narrador. La célula familiar surge aquí como el único camino para la formación de los individuos necesarios al país y representa, a su vez, el dispositivo de control más efectivo del género y la sexualidad. Claro está que la noción de familia marcada posee su eje simbólico entorno a los aspectos relacionados con la reproducción y la adecuada representación del binomio masculino/femenino. Si esta familia hegemónica es transgredida, los hijos surgidos de ella no serán los más adecuados $-\mathrm{y}$ la familia de Chucho está en este apartado poco plausible. ${ }^{51}$

Desde el principio, Chucho es mimado al extremo por su madre y, en su afán de ataviarlo bellamente, lo traviste para mostrar su hermosura femenina. Además, el narrador muestra los "yerros" de la figura materna al evidenciar la tolerancia de ésta para con su hijo:

\footnotetext{
${ }^{51}$ La visión de la familia consentidora del hijo único no es nueva. Con anterioridad, José Joaquín Fernández de Lizardi había expuesto -en El Periquillo Sarniento (1816), La Quijotita y su prima (1818) y La vida y hechos del famoso caballero Don Catrín de la Fachenda (1831) - una crítica a las familias que hacían demasiados mimos o criaban a sus hijos con laxitud. Para el escritor independentista, educar a los hijos de esta forma traía consigo una serie de faltas en su conducta posterior. El Periquillo, la Quijotita y Don Catrín son personajes poco prudentes para la sociedad mexicana planteada por Fernández de Lizardi, cuyo principal objetivo era brindar el molde para la colectividad criolla. Estos personajes representaban el antagónico de la vida productiva y se les evidenciaba para denunciar lo poco favorable de sus actitudes. Con esta aseveración no se pretende hacer un demérito a la magnífica obra de Fernández de Lizardi, sino señalar el contexto ideológico del que surgen sus novelas.
} 
todo lo solicitado por Chucho es concedido. Por su parte, el protagonista, considera muy provechosos los cuidados de su madre y se vuelve un fanático de su propia persona. Conoce la androginia de su belleza y cae en el desliz genérico del afeminamiento, tan temido en el siglo XIX. Al respecto, Monsiváis menciona: "La descripción del gay es clarísima, pero no se producen las conclusiones verbales. Los lectores no admitirían un texto centrado en un marica explícito, y por eso Cuéllar describe sin etiquetar al personaje que acentúa con la edad su afeminamiento, su dandismo y su habla, presumiblemente la de los homosexuales de la época". ${ }^{52}$ La evidencia de un acto "homosexual" hubiera sido un desparpajo moral insoportable para la sociedad decimonónica al grado de ni siquiera publicarse. El narrador es cuidadoso de aludir directamente a la conducta sexual de Chucho y prefiere "andarse por las ramas" de la caracterización "afeminada", que ya por sí sola ocasionaba cierta incomodidad en la cosmovisión de su tiempo. Por ello, como bien acota Monsiváis, todo el mapa simbólico y las referencias del "invertido sexual" estaban dados de antemano, pero la elipsis del tema sexual era inevitable: "El 'vicio nefando' se despliega pero sin las palabras que vuelvan innegable su existencia. En el momento más atrevido de la novela Cuéllar menciona a la 'raza ninfea', la especie de los ninfos o 'mujerucos'. Y aun esto con disfraces". ${ }^{53}$

Por otro lado, para Chaves, el mote de "ninfo" significa para Chucho una especie de cambio genérico. Según este crítico, la referencia a las ninfas alude a un entorno meramente femenino. Así, al adjetivar a Chucho como "ninfo" se le otorga un revestimiento semántico totalmente asimilado con lo "mujeril": "El agregado de el Ninfo implica una vuelta de tuerca más, una inversión semántica que alude a una sexual, una referencia culterana en que las ninfas siempre son mujeres y donde sólo puede existir un ninfo si se es un amujerado. Es una

\footnotetext{
${ }^{52}$ Carlos Monsiváis, Que se abra esa puerta, p. 79.

53 Ibid., p. 80.
} 
operación lingüística equivalente a decir 'Chucha la fauna', puesto que los faunos suelen ser masculinos" ${ }^{54}$ Ahora bien, ¿cómo interpretaba el lector decimonónico la presencia nínfea de Chucho? O, mejor aun, ¿cuál sería el objetivo de Cuéllar al articular un discurso sobre un sujeto "afeminado"? ¿Acaso había una rotunda amenaza por parte de la "raza nínfea" hacia la virilidad nacional? ¿Alude entonces la novela a un grupo social ya bien articulado y definido dentro de la sociedad mexicana, que sólo necesita unas cuantas referencias para ser identificado inmediatamente por el lector? El texto de Cuéllar no sólo crea a un personaje "afeminado", sino que señala directamente una conducta con una representación posiblemente en ascenso. Esto delata la visión directa del "amanerado" por las calles de México. Seguramente, la exacerbación de Chucho por su cuidado personal evidenciaba a los predecesores de aquellos "jovencitos" merodeadores de la calle Plateros durante el porfiriato $\mathrm{y}$, de paso, mostraba vaporosamente la existencia de un nutrido gueto de "invertidos". 55

La novela de Cuéllar puede ser vista a través del temor y rechazo provocado por el “afeminado" en sus páginas. Su "discurso delator" acerca de la conducta de Chucho denota un sitio negado en la cultura y la sociedad mexicanas. La visión del "invertido" sólo puede causar odio entre sus observadores, puesto que se trata de un ser situado en los márgenes de la institución "heterosexual-patriarcal". Esta visibilidad del "afeminado" funciona para crear una imagen sobre él mismo. El estereotipo del joven mimado al extremo, cuidador de su imagen y delicado en sus ademanes enclava profundamente en la imagen que, durante

\footnotetext{
${ }^{54}$ Chaves, "Afeminados, hombrecitos y lagartijos", p. 77.

55 "Para desgracia de la joven nación mexicana, Chucho no es alguien excepcional, sino que tiende a multiplicarse en la sociedad: 'Y no se crea que describimos en Chucho un ser fantástico, novelesco y que, a fuer de aparentar originalidad, le prestamos tintas de nuestra propia cosecha, no señor; por desgracia en esta época y en esta sociedad abundan estos adeptos del escándalo y de la inmoralidad"'. Chaves, "Afeminados, hombrecitos y lagartijos", p. 77.
} 
décadas, se ha tenido del homosexual en México. ${ }^{56}$ Cuéllar propone entonces un texto que sirva de contraejemplo de las costumbres pertinentes para los "hombres": parte de la denigración de la figura abyecta para salvaguardar la honrada:

A la educación afeminada, Chucho agrega el lujo y el ocio que le permiten los recursos paternos, ingredientes necesarios para que se produzca un tipo social tan negativo como el suyo, esto a juicio del narrador, que compara a Chucho, a quien llama "gusano social", con "un animal ponzoñoso con alas" (el veneno es la educación afeminada de la madre, las alas las debía a la riqueza ociosa) y con "esa pequeña víbora de la Tierracaliente, que se llama coralillo, vestida con hermosos colores, pero cuya picadura es mortal". 57

Deberá pasar más de una centuria todavía para que la imagen de un hombre como Chucho sea advertida sin la carga peyorativa poseída en su momento. A menos de tres décadas de concluir el siglo XIX, la imagen del "afeminado" poco tiene de positivo en la cosmovisión mexicana. $^{58}$

Poco antes de la publicación de la Historia de Chucho "el Ninfo", comienza en Europa -sobre todo en Alemania, Francia e Inglaterra- a discutirse sobre la creación de un

56 Al día de hoy, aún sorprende el número de personas que piensan la "homosexualidad" como resultado de una educación poco adecuada para el varón. El discurso establecido sobre la sexualidad en las familias y diversos medios de comunicación nacionales están impregnados todavía de esta relación entre hijo único o menor y padre o madre consentidores. Es evidente que el cambio legal no produce instantáneamente un cambio en la mentalidad social, y es en esta instancia donde se produce buena parte de la discriminación hacia el "disidente sexual".

${ }^{57}$ Loc. cit.

${ }^{58}$ La relación entre ocio y riqueza señalada por el narrador respecto de Chucho conforma todo un emblema de defensa utilizado por las clases medias y populares a principios del siglo XX en el país. Páginas más adelante se verá cómo en la novela Los cuarenta y uno (1906) de Eduardo A. Castrejón -realizada a partir de la escandalosa fiesta en la calle de la Paz de la Ciudad de México en 1901, y cuya historia "representa" las vidas de los participantes de dicho acontecimiento- hay una denuncia, por parte del narrador, de las clases encumbradas que despilfarran su tiempo y dinero en situaciones poco favorables para el desarrollo nacional. La exaltación de la clase obrera radica en su virilidad, opuesta al supuesto afeminamiento de la burguesía mexicana del porfiriato. 
nuevo personaje: el "homosexual". Las sociedades de estos países habían iniciado, desde hacía ya varias décadas, un proceso de vincular las conductas con la noción de delito y no con la de pecado. La Iglesia dejó de tener injerencia en los asuntos públicos para ceder su paso a la medicina y la criminología. Estas últimas plantearon un acercamiento totalmente "científico" a la conducta del hombre. Se interesaron por demostrar los rasgos del asesino, el ladrón, la prostituta y los disidentes sexuales. Para ello hicieron uso de los estereotipos ya creados en sus respectivas naciones y redactaron diversos tratados al respecto. Los disidentes sexuales pasan de ser pecadores a enfermos o delincuentes. Se habla de su falta de responsabilidad ante su entorno y de las infracciones cometidas contra la moral, pero también hay un dejo de piedad al calificarlos como enfermos. Esta articulación de pseudoconocimientos sobre la disidencia sexual es conocida como el "discurso higienista", por su propuesta de limpiar la sociedad decimonónica de los individuos poco adecuados.

Numerosos investigadores ${ }^{59}$ ven en el "discurso higienista" una apuesta por la reproducción humana que garantice un constante consumo. Así, los disidentes sexuales, al no tener por objetivo la procreación, sino la simple búsqueda del placer, quedan excluidos de antemano. Aquí inicia una profunda segregación del individuo homosexual, muy similar a la del sodomita de los siglos pasados. Además, con la identidad homosexual se plantea una nueva forma de encajonar la actividad homoerótica en una sola caracterización. De este modo, los resultados de las investigaciones médico-judiciales sobre la disidencia social eran tomadas como formas inapelables de la eclosión y visibilidad del fenómeno "disidente sexual" ${ }^{60}$ La homosexualidad es creada con un impulso de constreñirla para destruirla

\footnotetext{
${ }^{59}$ Michel Foucault, Philiphe Ariès, Francis Mark Mondimore, José Amícola, Óscar Guasch, entre otros.

${ }^{60}$ Carlos Monsiváis menciona uno de estos textos que pretende tipificar las sexualidades "anormales": "En Los criminales en México [1904], Carlos Roumagnac, criminalista, periodista y literato, da cuenta de su
} 
posteriormente; su contraparte, la heterosexualidad, era la única actividad erótica que gozaría de plena aceptación, y las reglas de su contacto estarían fijas durante largo tiempo en la mentalidad occidental. El sodomita deja a un lado el pecado y adquiere la caracterización de enfermedad para ser el "homosexual" de la era moderna.

Muchos de estos tratados sobre la homosexualidad fueron llegando a México de forma lenta, sin embargo su pretendido carácter científico se arraigó profundamente en la mentalidad mexicana. El "afeminado" cedió su paso al homosexual de los años veinte del siglo XX en adelante. Pero antes de que cundiera por todo el país la visión del homosexual como un pobre enfermo/delincuente con posibilidad de cura, hubo un hecho tremendamente sacudidor de la sociedad mexicana del porfiriato: el baile de los 41 acaecido en 1901. Este acontecimiento ha sido referencia ineludible de la homosexualidad. Todos los estudios elaborados sobre el homoerotismo en México citan esta fiesta y la señalan como el suceso más visible de la disidencia sexual del México independiente. Nunca los asistentes travestidos y “masculinos” al baile de la calle de la Paz imaginaron el eco que causarían sobre las generaciones futuras. Incluso, ellos mismos hubieran querido no hacerlo por el escarnio que tal hecho significaba. Los creadores del boom histórico-cultural sobre la fiesta de los 41 fueron sus propios detractores, quienes vieron en semejante fiesta la más abyecta de las reuniones. Sí, el afeminado era conocido por textos que lo evidenciaban como las novelas de Cuéllar o de Payno, o por sus vagabundeos en las céntricas calles de la ciudad; pero nunca se había producido un escándalo de semejantes magnitudes. Lo peor del caso, para la élite

investigación en la cárcel de Belén y la nueva Penitenciaría Federal de la capital. El director de la prisión intenta aislar a los 'pederastas conocidos', para terminar con las 'peleas sangrientas' de los reclusos en celo. En respuesta, los señalados desfilan ante los otros presos 'sin timidez o vergüenza, sino, por el contrario, desplegando con ostentación sus voces femeninas y amaneramiento"'. Monsiváis, Que se abra esa puerta, p. 90. 
aristocrática y política, fue el involucramiento de varios de sus más célebres integrantes en dicha reunión. Al respecto, Miguel Capistrán -en un artículo pionero sobre el temamenciona lo siguiente:

Al principio el diario El Imparcial, vocero de los intereses políticos y económicos de Porfirio Díaz y su camarilla de amigos y protegidos, guardó sospechoso silencio en torno del asunto. Pero ante la magnitud que tomaba el escándalo, se vio obligado a declarar: "Hay quienes aseguran que entre los individuos aprehendidos había capitalistas y otras personas pertenecientes a familias muy distinguidas... Creemos necesario rectificar esas opiniones. La verdad es que la en la referida reunión, excesivamente inmoral y escandalosa, sólo se encontraban [sic] un grupo de más de 40 hombres, muy conocidos por sus costumbres depravadas, y que en más de una vez han figurado en escándalos por el estilo. La mayor parte cambiaron de nombre al ser aprehendidos, pero la policía ha podido identificar a muchos, entre quienes se encuentran un individuo que ejercía como dentista y otro que se decía abogado". ${ }^{61}$

La cita refiere al "homosexual" como individuo perteneciente a las clases populares y defiende a la élite -lo que recuerda la acusación de "sodomita" como el "otro abyecto"-. Así, el periódico garantiza para los intereses de sus protectores un salvoconducto de rectitud acerca de su orientación sexual y, deliberadamente, acusa de "inmorales" a la población no involucrada en los asuntos políticos y económicos del país. El acto de ocultación de los “distinguidos" personajes hallados en el "escandaloso baile", resulta ya una situación poco efectiva por los fuertes rumores sobre el origen encumbrado de sus asistentes, entre quienes destaca Ignacio de la Torre, yerno del presidente. ${ }^{62}$ Por razones obvias, ni el mandatario ni

\footnotetext{
${ }^{61}$ Miguel Capistrán, “Un día como hoy hace más de ciento”, en José Ricardo Chaves y otros, México se escribe con J, p. 59.

${ }^{62}$ Entre otros distinguidos asistentes al baile sobresalen Antonio Adalid y Alejandro Redo.
} 
las familias aristócratas iban a permitir semejante escarnio, aunque poco tenían ya en sus manos para defenderse.

El baile de los 41 produjo un escándalo inusitado en la sociedad de su tiempo. Fue un hecho extremadamente citado y toda la población quedó enterada de lo sucedido. Los rumores fueron extendidos rápidamente por toda la ciudad y, de ahí, al interior de la República. El imaginario mexicano asoció el baile y su revestimiento semántico con la figura del "afeminado" o "invertido sexual". De este modo, el 41 fue convertido en el leitmotiv de la homofobia nacional: "El mexicano que vive en el número 41 de una calle cualquiera invariablemente hace algún comentario jocoso para adelantarse a la reacción de las personas a quienes informa su domicilio. El que tiene 41 años evita mencionarlo, o bien se atribuye 40 o 42. Cuando el número del asiento en un espectáculo es el 41, nunca faltan los chistes para festejar la coincidencia". ${ }^{63}$ La denigración de la figura del homosexual en la sociedad heteronormada es tan profunda que, cualquier asimilación con el "sujeto marginal", resulta inmediatamente denostada. Capistrán demuestra eso no sólo en el mundo de lo cotidiano, sino también en el artístico: "Inclusive hubo una película rusa que se exhibió en todo el mundo con el título de El 41 (el 41 es el número del disparo con el cual una guerrillera que lleva 40 hazañas balísticas tiene que dar muerte a su amante) y en México tuvo que ser anunciada como El último disparo" ${ }^{64}$ Claro está: pocos serían los asistentes a la exhibición de dicha cinta si su propio título se asimilaba con algo tan peyorativo como la homosexualidad.

Uno de los hechos más denigratorios asestado contra los asistentes al baile de los 41 $-\mathrm{y}$, en general, contra cualquier "invertido sexual" de la época- está constituido por los

\footnotetext{
${ }^{63}$ Capistrán, “Un día como hoy hace más de ciento", p. 53.

${ }^{64}$ Loc. cit.
} 
versos acompañantes de las caricaturas realizas por José Guadalupe Posada al respecto. En este panfleto "antihomosexual", los "afeminados" reciben todo el peso de la burla y el escarnio: Posada los dibuja vestidos como elegantes damas con bigote bailando con sus respectivos amantes; mientras los versos no se cansan de ridiculizar sus "debilidades" para emparentarlos con la imagen de la "mujer". No hay justificación alguna para la falta cometida y su desprestigio social es el castigo mínimo recibido, puesto que, como los mismos versos rebelan, fueron enviados a trabajos forzados al Valle Nacional en Yucatán, no sin antes barrer las calles de la Ciudad de México en su camino hacia la estación de trenes.

Para Carlos Monsiváis, el baile de los 41 representa la primera gran visibilidad de los "homosexuales" en México y, lamentablemente, significa también la forma de castigar la disidencia sexual desde el ámbito social, político y legal. A su vez, demuestra -como lo hiciera "Cotita de la Encarnación", "Señora la Grande” y demás sodomitas quemados durante el periodo colonial- la efervescencia de un gueto bien consolidado dentro de la sociedad mexicana del porfiriato. ¿Acaso no muchos bailes similares quedaron en el anonimato por no haber cerca un gendarme que los descubriera? Así, queda grabado, en la memoria colectiva, la visibilidad y castigo correspondientes a un grupo de homosexuales descubiertos en una alegre fiesta de principios del siglo pasado.

Un coadyuvante de la estrategia homofóbica porfiriana contra los 41 es la "novela" de Eduardo A. Castrejón -seudónimo- titulada Los cuarenta y uno. Novela crítico-social y publicada en 1906. El texto intenta ser un relato de la fiesta y sus protagonistas desde una perspectiva que defiende a la sociedad hetero-patriarcal. Sin embargo, el verdadero propósito de la novela es usar como chivo expiatorio al homosexual para hacer una profunda crítica a la aristocracia mexicana y exaltar los valores de la clase obrera. En palabras de Marquet, Castrejón actúa de la siguiente forma: "Adjudica crímenes a la aristocracia y nada le parece 
más fácil para concitar la unanimidad de los lectores que la homosexualidad. Aunque no le importe mayormente, hay que sacrificar al homosexual, es sangre barata, nadie meterá las manos en su defensa". ${ }^{65}$ No es nuevo este recurso de tachar de disidente sexual al adversario político, cultural o económico. Ya los españoles lo habían hecho con los judíos y los indígenas americanos, y lo mismo ocurrió con el famoso caso de la Orden de los Caballeros Templarios en la Edad Media. ${ }^{66} \mathrm{El}$ axioma dictamina que todo aquel cuya vida sexual no esté en los parámetros "adecuados", tampoco tendrá una "buena" representatividad en la sociedad y, mucho menos, en los asuntos relacionados con la dirección de un gobierno. Si la clase alta mexicana está pervertida ¿cómo podría entonces encaminar al país rumbo al desarrollo? La respuesta es clara, y Castrejón sabe usarla en su provecho: desde un escondite bien guarecido, el autor ataca a su enemigo con el más abyecto de los títulos.

La fecha de publicación de Los cuarenta y uno está en concordancia directa con la izquierda de su tiempo. El periodo porfirista, en su afán de permanecer al mando, ha cavado su propia tumba y sus detractores aprovechan el descontento social para fustigarlo. Por ello, la novela apela a la reconstrucción nacional con base en las clases populares, oprimidas por los "invertidos" aristócratas. Castrejón juega con la antigua querella sobre la visión de un estado nacional libre de "vicios" y sujetos "transgresores" y la pone, nuevamente, sobre la mesa, sólo que agrega un cierto toque socialista -puesto en boga, más tarde, durante los años

\footnotetext{
${ }^{65}$ Antonio Marquet, "Castrejón, Cóccioli y Novo: La novela gay en la primera mitad del siglo XX", en Revista de Literatura Mexicana (México: UnAM, 2006), vol. XVII, no. 2, p. 49.

${ }^{66}$ Los Templarios fueron una Orden de Caballeros, fundada en 1119, cuya misión era socorrer a los peregrinos en su camino hacia Tierra Santa. Se trataba de individuos consagrados con votos de castidad y pobreza que, paradójicamente, fueron acumulando una enorme cantidad de bienes. Su función de cuidadores de peregrinos finalizó con la caída de Tierra Santa en manos de los musulmanes, pero iniciaron otra: la administración de las fortunas heredades de sus benefactores. No obstante, fueron objeto de la codicia de Felipe IV, rey de Francia, quien, para apoderarse de sus bienes, los acusó de "sodomitas". El suceso rindió frutos en 1307 y los Templarios fueron arrestados, torturados y asesinados por causa del delito imputado. El papa Clemente V poco quiso involucrarse en la defensa de los supuestos "sodomitas" y disolvió la orden en 1312.
} 
veinte y treinta. ${ }^{67}$ Por ello, Los cuarenta y uno puede ser clasificada como un texto panfletario con un uso de la homofobia colectiva en su favor, cuya denigración del "invertido sexual" corresponde claramente a una concepción heteronormativa y patriarcal de la sociedad mexicana.

Casi un lustro después de la publicación de su panfleto homófobo, Castrejón pudo estar feliz de observar la caída del régimen y aristocracia porfirista. La Revolución Mexicana trajo consigo una nueva forma de pensar el país con base en el campesino y el obrero, para llegar a un reparto más justo de las utilidades producidas por la tierra, la industria y los servicios. Pero el cambio no fue sólo en la actividad económica y política, sino también en la sexualidad. Monsiváis ve en la Revolución un contacto con mayor laxitud entre los cuerpos, y se pregunta cómo no iba a producirse semejante situación si el movimiento armado acabó con el resguardo moral de la sexualidad:

\begin{abstract}
A la revolución le toca dar el golpe mortal a la estructura de silencios absolutos que a todos culpabiliza, entre masas que se desplazan a la fuerza y señoritas que hipotecan la virginidad por unas horas. Las tomas de ciudades, las migraciones masivas, las legiones de hijos sin padre, las oleadas de prostitutas, hacen inocultables las exigencias del deseo. Por así decirlo, la revolución en algo "sexualiza" el país, hace que en el teatro frívolo afloren con regocijo las realidades del cuerpo, se burla de los silencios dignísimos a propósito del demonio y la carne, vuelve "conquista social” la mezcla de oficiales de alto rango y prostitutas, advierte una nueva institución nacional en las madres solteras (por lo común desertoras de los pequeños pueblos), y, sobre todo, debilita el peso de las prohibiciones morales.
\end{abstract}

${ }^{67}$ Más adelante se verá la relación de enemistad establecida entre la homosexualidad y el partido comunista. Los primeros representados por la generación de los "Contemporáneos"-Salvador Novo, Xavier Villaurrutia y Carlos Pellicer, entre otros- y los segundos por el "nacionalismo cultural"-Diego Rivera, José Clemente Orozco, Manuel Maples Arce, etcétera. 
"Sexualizar" a México, así sea hoy una medida calificable de conservadora, desbarata nociones tiránicas ya que, al fin y al cabo, "si me han de matar mañana, mejor peco de una vez". ${ }^{68}$

La "bola" restituyó al cuerpo el goce de sus pulsiones sin un pudor extremo. Una suerte de carnaval, al estilo bajtiniano, mezcló lo puro con lo abyecto, la sangre de los muertos con las secreciones de los cuerpos en plena excitación. Incluso, el papel de la mujer en el ámbito público, como es el caso de las "adelitas", nunca había sido tan apabullante. Ante de la necesidad de ejército, los coroneles y generales prescinden un tanto de las ataduras de género y consienten la incorporación de las mujeres a sus filas. Sin embargo, esta "sexualización" de México planteada por Monsiváis está marcada por la presencia de un fuerte machismo y una nueva defensa exacerbada de la virilidad. El hombre "débil" o "afeminado" poco o nada tenía que ver con el movimiento armado. Su lugar estaba fuera de la reluciente gestación de un estado nacional vigoroso, que abominaba los "vicios" y "corrupciones" de la masculinidad.

El México posrevolucionario nace con una huella de profundo nacionalismo. Las costumbres correspondientes a los "hombres" son exaltadas de forma unánime por todo el país. Igualmente, surge un nuevo acontecimiento conocido como "nacionalismo cultural", cuya principal consigna es que, a partir del movimiento revolucionario, se cree una nueva nación con base en las clases populares y la cosmovisión mexicana. Por las condiciones histórico-sociales del porfiriato, hay un rechazo masivo a la vieja aristocracia y a la extranjerización del país. ${ }^{69}$ Lamentablemente, estas consignas de restituir al pueblo las

\footnotetext{
${ }^{68}$ Monsiváis, Que se abra esa puerta, p. 94.

69 Al respecto, Javier Garciadiego menciona: "Es incuestionable que la revolución fue el acontecimiento histórico más importante del siglo $\mathrm{xX}$, en tanto que produjo un nuevo Estado, encabezado por unas clases medias no radicales pero que vieron la necesidad de satisfacer los principales reclamos de los grupos populares que había participado decisivamente en la lucha. La revolución había
} 
garantías que durante tanto tiempo le habían estado negadas, está acompañada por un rotundo rechazo de la figura del "disidente sexual". La sociedad mexicana posrevolucionaria adora la imagen de un "hombre nuevo", cuyas características están enraizadas en la virilidad, la fortaleza, el valor, la familia y, por supuesto, la heterosexualidad..$^{70} \mathrm{El}$ "hombre nuevo" debe estar entregado por completo al trabajo y, por ello, debe tener acceso a todas las prerrogativas que el Estado tiene obligación de brindar: educación, salud y remuneración suficiente para encontrarse en completo bienestar. Toda esta ideología ayudó notoriamente a cambiar ciertos aspectos del país: produjo, sin duda, un mejoramiento de las clases bajas urbanas y rurales, a la vez que reforzó la posición de la clase media.

El movimiento artístico defensor de esta ideología folclórico-comunista está representado por el muralismo mexicano y sus artífices -Diego Rivera, José Clemente Orozco, David Alfaro Siqueiros y Rufino Tamayo, entre otros-. Las paredes de los viejos edificios coloniales, decimonónicos y porfiristas son cubiertos con grandes imágenes surgidas de la cosmovisión mexicana y del trabajo de campesinos y obreros. La historia mexicana aparece retratada con gran detalle y las clases populares representan la fortaleza mexicana por la lucha y el trabajo. Este gran trabajo artístico está en contra de un "arte burgués", en el que las pinturas, por poner un ejemplo, sólo podían ser asequibles para quien pudiera pagarlas. Se busca entonces un efecto contrario: la accesibilidad del arte para las

sido un proceso bélico y sociopolítico, que implicó el ascenso de los sectores medios y populares y el desplazamiento de las oligarquías porfirianas. [...] Nacido en 1920, el nuevo Estado no resultó democrático, aunque sí con identidad nacionalista; autoritario, pero ampliamente legitimado". Javier Garciadiego, "La Revolución", en Pablo Escalante Gonzalbo y otros, Nueva historia mínima de México (Xalapa: Universidad Veracruzana, 2010), p. 290.

70 Para Carlos Monsiváis, este "hombre nuevo" es muy similar al propagado por la Revolución rusa y, posteriormente, por la cubana. No obstante, la denigración del homosexual es característica tanto de la mexicana como de las dos anteriores, donde se le persigue e intenta "reformar". 
clases populares, es decir, acercar a las masas al trabajo del pintor, el escultor, el escritor, etcétera.

En el campo literario, se pone en boga la literatura de corte revolucionario e indigenista. A su vez, nace una vanguardia conocida como estridentismo, cuyos principales autores fueron Germán List Arzubide, Manuel Maples Arce y Arqueles Vela, entre varios más. El estridentismo es movimiento fuertemente influido por el futurismo, conjugado con una fuerte presencia de la cultura popular mexicana. El movimiento armando tiene un eco notorio en el estridentismo por su compromiso con las clases obreras, por ello se propone escandalizar a la clase aristocrática para romper con sus principios.

Sin embargo, en medio del "nacionalismo cultural" surge un grupo artístico totalmente opuesto a muchos de los principios planteados por el muralismo, el estridentismo, la novela de la revolución e indigenista. Se trata de la generación de poetas más influyente del siglo pasado en México: los Contemporáneos, conformada por Salvador Novo, Xavier Villaurrutia, Carlos Pellicer, Elías Nandino, Jaime Torres Bodet, Jorge Cuesta, Bernardo Ortiz de Montellano, Gilberto Owen, José Gorostiza y Enrique González Rojo. Este movimiento literario está provisto de la lectura de autores europeos y su intención es “modernizar" a México en el campo de las letras. Los Contemporáneos optan por una "poesía pura" de características estéticas relacionadas más con una visión interiorizada del hombre que con su entorno, dotando a su poesía de un sentido universal. Hay en ellos un cosmopolitismo muy evidente que contrastará inmediatamente con el "nacionalismo cultural" en boga. Además, la disidencia sexual de algunos de sus miembros produce en sus coetáneos un intrínseco repudio. Así, la presencia de los Contemporáneos en el ámbito artístico, social y burocrático de México es una verdadera hecatombe para los exaltadores de lo mexicano, las clases populares y la masculinidad. 
¿Qué pasa con este conflicto cultural? ¿Cuáles son los medios de defensa y ataque de ambos bandos? Obviamente, los tutores del "nacionalismo cultural" ven en ellos una amenaza rotunda para la construcción del nuevo México posrevolucionario y buscan, a toda costa, atrincherarlos. La homosexualidad de algunos es buen motivo para denigrarlos y subrayar su carácter indeseado en el orden social. Desde el ámbito político y literario se lanzan consignas contra su efervescente presencia: Alfonso Reyes se extraña de su presencia en el itinerario cultural mexicano y los tacha de "maricones", situación que, según él mismo menciona, lo hace sufrir; Manuel Maples Arce -quizá el más encarnizado detractor de los Contemporáneos- los asola con profundas críticas hacia su sexualidad y nulo compromiso de su literatura con lo social; Diego Rivera los satiriza en "Los anales" y escribe, además, "Arte puro: puros maricones", donde los critica por su "arte burgués" y, obviamente, su "homosexualidad":

Los guardianes de este nacionalismo (entre los que se cuentan novelistas de la revolución, poetas, funcionarios, pintores) quieren eliminar de la nación misma, en una noche de cuchillos largos del presupuesto y de la respetabilidad, a los agentes del debilitamiento. El nacionalismo cultural es enemigo implacable que, con su teoría de las virtudes de la raza, fundamenta lo ejercido con choteos y agresiones; ese rencor activo contra lo diferente, que sólo exalta la conducta admitida. Por eso el tema de la homosexualidad, así abarque a una parte de Contemporáneos y no sea criterio literario, es indispensable para entender el proceso de integración cultural. La tiranía de la ortodoxia sexual convierte a los heterodoxos en los blancos favoritos de la sociedad represiva. ${ }^{71}$

Los Contemporáneos, por su lado, responden con la afirmación de su estado homosexual. Poemas como el "Nocturno de los Ángeles", "Nocturno de la alcoba", "Amor conduce noi

\footnotetext{
${ }^{71}$ Monsiváis, Que se abra esa puerta, p. 61.
} 
ad una morte" y "Décimas de nuestro amor", de Xavier Villaurrutia, hacen gala de un exquisito homoerotismo; en contraparte, Salvador Novo juega irónicamente con la figura del “maricón” y escandaliza las mentes más heteronormadas; mientras que Carlos Pellicer exalta el cuerpo del amado junto a una naturaleza tropical.

Los Contemporáneos son, entonces, aparte de un punto de partida poético dentro de la literatura mexicana, un sitio primordial cuando se habla de homoerotismo dentro del país. La figura más contestataria del grupo, Salvador Novo, representa un encomiable sitio de resistencia y, a la vez, recrea lúdicamente la supuesta identidad abyecta de maricón, y cuestiona con ello todo el dispositivo genérico nacional. Novo, maestro de la ironía y la burla, hace de su situación "marginal" un acontecimiento pomposo: fue uno de los pocos sujetos que desafió por completo la heteronormatividad mexicana en una época hermética y poco tolerante con la diversidad sexual. ${ }^{72}$

Esta situación contestataria aparece claramente representada en La estatua de salescrita antes de 1945, pero publicada hasta 1998 por el Conaculta-, en la que Novo describe con ironía, fluidez y humor sus primeros cuarenta años de vida. Sin embargo, el texto biográfico es, a la vez, una crónica sobre el gueto homosexual del país durante la primera mitad del siglo Xx: Novo no escatima recursos ni información, y brinda ampliamente al lector los detalles de ese mundo, no tan soterrado como pudiera pensarse, donde concurren

\footnotetext{
72 Juan Carlos Bautista realiza una interesante síntesis de la señera figura que Salvador Novo representa: "Novo no fue el primer homosexual obvio que recorriera las calles de la Ciudad de México. Fue el primero, sí, que lo dijo, que lo nombró y que le dio importancia. Nuestro padre Adán, con sus amaneramientos como proclamas personalísimas, como afrentas estéticas, como gestos de combate. [...] La estrategia de ubicación, de identidad ineludible y desesperada, de aquellos que no podían y/o (sic) no querían ocultar su orientación sexual, se apegaba al estereotipo del maricón, del joto, del rarito. Novo asumió parte de ese estereotipo, buscó decididamente dotarlo de poder, y a partir de ahí, armado de una cultura vasta, de un temperamento teatral y una lengua y una pluma temibles, comenzó su guerra, haciendo alarde de su propia condición". Juan Carlos Bautista, "La noche al margen. Brevísima relación de la vida nocturna gay", en México se escribe con J, pp. 212-213.
} 
múltiples personajes -unos encumbrados, otros más desconocidos- que circulan cotidianamente en busca de un encuentro fortuito o la razón afectiva de su existencia. De esta forma, La estatua de sal se convierte en un atractivo documento condensador de la vida homosexual de México, especialmente la del Distrito Federal, y, por esta razón, puede observársele, incluso, como un texto de carácter historiográfico. Además, la biografíacrónica de Novo es el único texto que documenta el gueto mexicano de la diversidad sexual durante estos años, situación aún más favorecedora para su vital importancia.

Carlos Monsiváis -ferviente estudioso de la vida literaria y privada de Salvador Novo- menciona cómo en el mismo título de La estatua de sal, el poeta y cronista establece los parámetros de valoración sobre los hechos narrados. Vinculado estrechamente con la sobreinterpretación del pasaje del "Génesis" sobre la destrucción de Sodoma -en cuyas líneas la tradición judeo-cristiana observó el supuesto desprecio de Dios hacia los sodomitas y demás "infractores" del correcto dispositivo de la sexualidad-, el título alberga una doble transgresión: la prohibición de mirar atrás y el propio acaecimiento del pecado "sodomético". La estatua de sal cataliza estas dos operaciones en una intensa curiosidad por lo no permitido: “Curiosidad y transgresión. En esta magnífica evocación, Novo es el novelista que la urgencia del diarismo nulificó, es el recreador de una extrañísima niñez provinciana, y es el gay que a los cuarenta años de edad, con el costo previsible, busca otorgarle a la materialidad posible, la de la escritura, la experiencia fundamental de su vida, la homosexualidad". ${ }^{73}$

Esta vuelta al pasado realizada por Novo inicia con sus primeros años de vida. El narrador de La estatua de sal trae a colación sus recuerdos más lejanos y busca, mediante esta acción, advertir numerosos antecedentes de su vida actual. Para lograr tal cometido,

\footnotetext{
${ }^{73}$ Monsiváis, Que se abra esa puerta, p. 69.
} 
cualquier circunstancia es imprescindible y, a la vez, motivo de análisis. El rastreo de su homoerotismo se convierte, entonces, en un leitmotiv a lo largo de la narración y, lejos de ser una biografía, el texto opera una autotransfiguración en apología del deseo. Esta situación aparece enormemente representada cuando, durante su niñez y adolescencia, Novo inicia el espléndido camino de la satisfacción sexual. Además, este segmento es, sin lugar a dudas, pionero en la literatura mexicana, ya que se trata del primer texto que busca desvelar, desde una perspectiva homodiegética, el inicio del deseo homosexual. Ejemplo de ello es el placer experimentado durante los juegos infantiles del narrador:

De esta época datan mis primeros recuerdos sexuales [...] Había en casa un mocito, de nombre Samuel, con quien me ponía a jugar. Mientras jugaba solo, con mis cubos y mis cajas vacías de galletas, que construían altares, no necesitaba de más. Pero cuando jugaba con aquel chico, yo proponía que el juego consistiera en que fuéramos madre e hijo, y él entonces tenía que chupar mi seno derecho con sus labios duros y su lengua erecta. Aquella caricia me llenaba de un extraño placer, que no volví a encontrar sino cuando muchos años más tarde, al sucumbir a la exclusividad de su tumescencia, retrajo a mi recuerdo aquella primera y quizá definitiva experiencia, que a toda la distancia de su adquisición como forma predilecta de mi libido adulta, puede haber sido el trauma original que la explique. ${ }^{74}$

Estos pequeños instantes de goce, muy reiterados a lo largo de esta primera parte de la autobiografía, están hilvanados también con la importancia de la belleza del protagonista, quien busca, a toda costa, demostrarse a sí mismo la fuerza de atracción proporcionada por su imagen. Las relaciones con los demás infantes le reafirman esta coyuntura y, además, lo vuelven centro de atención de diversas experiencias eróticas. De esta forma, aún tomando en cuenta la posible carga heteronormativa puesta en la educación de los amigos y compañeros

\footnotetext{
${ }^{74}$ Salvador Novo, La estatua de sal, pról. de Carlos Monsiváis (México: FCE, 2008), p. 78.
} 
de clase de Novo, hay un incipiente deseo homoerótico en las relaciones establecidas entre el narrador y aquéllos. Estas breves, pero significativas, experiencias conforman el universo erótico primigenio del protagonista y, a su vez, le sirven a modo de mecanismo orientador sus pulsiones, dado que sus contactos no son sólo con jovencitos, sino con algunas chicas, quienes buscan algún tipo de satisfacción erótica en la persona del narrador, aunque éste, al instante, las observa como poco satisfactorias.

Dos de los acontecimientos más importantes de esta etapa de descubrimiento durante su niñez radican en un contacto sexual más cercano. El primero de ellos es el realizado con Jorge, un jovencito varonil compañero de escuela, quien, de forma inesperada debido a su apariencia viril, besa, en una primera ocasión, al protagonista, y, posteriormente, casi al finalizar los cursos de primaria, lo besa nuevamente, pero ahora con el objetivo de tener un mayor acercamiento: "Sin soltarme, llevó su mano a su bragueta y extrajo de ella un pene erecto y rojizo que trató de poner en mis manos. Yo lo rechacé, horrorizado. [...] Recuperando ávidamente mi boca, Jorge empuñó su pene, y vi salir de él unas gruesas gotas grises que chorrearon sobre el piso". ${ }^{75}$ La respuesta del narrador a este episodio es la huída por el desconocimiento de lo sucedido; no obstante, esta abrupta escapada es paradójica: "Salí corriendo de aquél salón, aturdido, fascinado, desconcertado entre el goce infinito de aquel largo beso inolvidable y la angustia de aquella eyaculación asquerosa". ${ }^{76}$

El segundo suceso es el más definitorio para la sexualidad del protagonista. Ante este acontecimiento, los acercamientos anteriores son sólo pequeños atisbos de su deseo. El hecho consiste en la primera relación sexual del narrador con Pedro Alvarado, un jugador de béisbol:

\footnotetext{
${ }^{75}$ Novo, La estatua de sal, p. 106.

${ }^{76}$ Loc. cit.
} 
A su presión, volví la espalda, cerré los ojos, le dejé hacer, desabrochar mis pantalones con mano experta, tocarme y maniobrar con tan consumada pericia, que no experimenté el menor dolor -aunque tampoco el mínimo goce- al sentirme penetrado en un acto que imaginaba equivalente a la desfloración descrita en mi libro, pero que en la realidad de mi carne, guardaba apenas una molesta semejanza con la introducción de las cánulas para enemas a que me sometían en casa cuando enfermaba. Y ni vi, ni toqué su pene. ${ }^{77}$

Pero ¿cuál es el objetivo de detenerse en esta primera parte de La estatua de sal? ¿Dónde están los motivos por los que el texto de Salvador Novo reviste tanta importancia dentro del registro del homoerotismo en México? La respuesta más elemental a estas cuestiones está consumada en el mismo hecho de la reconstrucción de la niñez ofrecida por el autor. En esta etapa inicial de formación, el narrador recorre los más intrínsecos deseos y las más expeditas prohibiciones o anatemas. Como todo niño y adolescente, su vida transcurre entre el devenir de lo deseado y el recato ante una posible fustigación por lo obtenido. El habitus porfirista el mismo que condenó atrozmente a los asistentes al baile de la calle de la Paz en 1904- está instalado en la imaginería del joven protagonista. Además, la narración indaga en la concepción erótica tenida por sus demás compañeros y amigos. De este modo, La estatua de sal ofrece la estampa correspondiente a la sexualidad de un estadio histórico del país y, mediante la mirada del narrador, puede tenerse acceso a las contradicciones establecidas entre un dispositivo normativo y la verdadera búsqueda del deseo. El narrador puntualiza sus temores, atrevimientos y goces a través de sus aventuras, y muestra con ello el enfrentamiento

\footnotetext{
${ }^{77}$ Ibid., p. 111.
} 
entre lo aprendido en casa y el incipiente erotismo heterodoxo que nace en él. ${ }^{78}$ Todo el dispositivo de la sexualidad y la estructura de género establecida en México hacen su entrada en la biografía de Novo; sin embargo, el narrador observa cómo dichas normatividades son, frecuentemente, vulneradas tanto por él como por los otros. ${ }^{79}$ El homoerotismo que, en algún momento, pudiera pensarse soterrado en los albores del siglo XX, aparece muy bien retratado y, además, mediante el texto queda la clara percepción de la búsqueda del deseo en todo momento. ${ }^{80}$ Posiblemente, muchos de los chicos con los que el protagonista mantiene un

\footnotetext{
${ }^{78}$ Cuando Novo retorna a la Ciudad de México, hay un momento en que reflexiona sobre su condición "diferente" y menciona: "Me humillaba, no el pensamiento de ser un anormal; no el hecho de sentir por ese hombre un deseo una pasión que yo no alcazaba a sentenciar, a calificar de culpable; sino el hecho de que sin duda mi sentimiento era tan singular, me hacía tan único, tan extraño en el mundo, que si mi héroe lo conociera, lo probable es que me despreciara por ello, me humillara, me golpeara en vez de besarme". Novo, La estatua de sal, p. 126. Hay en esta cita una elocuente lucha entre el carácter de la disidencia sexual del narrador y el temor a la exhibición de la misma. Además, la automarginación, efectuada en el protagonista a causa de una heteronormatividad bien implantada, genera la posibilidad del rechazo en los demás ¿cómo alguien podrá amarme -o desearme- si soy un ser inadecuado?

79 Además, debe recordarse que Novo vivió su niñez y parte de la adolescencia en el norte del país, una zona que, en el imaginario popular, tiende a marcarse como más hermética con respecto a la diversidad sexual.

${ }^{80} \mathrm{Al}$ respecto, Antonio Marquet explica que "Novo recurre por ejemplo a la explotación de la paradoja como táctica que consiste en enunciar cierta afiliación para destruirla inmediatamente. Teórica, familiar, grupalmente..., es preciso invocar una autoridad, un principio explicativo, para ponerlo inmediatamente en entredicho, negarlo". Antonio Marquet, Que se quede el infinito sin estrellas (México: UAM, 2005), p. 46. Esta situación se extiende a lo largo de la narración, pero con mayor énfasis en las primeras páginas. La paradoja mencionada por Marquet es reiterada cuando el narrador se enfrenta con el rechazo directo o indirecto contra alguna representación de la homosexualidad, casi como una abrupta y contradictoria asimilación del insulto. La siguiente cita ejemplifica verazmente esta circunstancia: "Y una tarde, Guillermo regresó a casa con huellas evidentes de haber reñido. Por la noche, como dormíamos en la misma recámara, me atreví a preguntarle qué había pasado, y lacónicamente me dijo que había peleado con Carlos Dávalos y que no volvería a tratarlo, porque ése había resultado un puto. No averigüé más de aquel incidente; pero sentí que al escuchar a Guillermo condenarlo, me había ruborizado; que aquel desprecio, aquella ruptura violenta de una vieja amistad, se originaba justificadamente en la misma culpa siniestra de que yo me sabía el indefenso reo; y que ese destino de abyecta, súbita e irremediable segregación me aguardaba en la vida, en cuanto cada uno de estos seres equilibrados y normales que tenían novias y acariciaban a las putas, fueran descubriendo que yo, en cambio, alentaba una sed angustiosa e irrefrenable por el beso de un héroe cinematográfico". Novo, La estatua de sal, p. 128. Este tipo de asimilación paradójica del insulto es muy evidente en la literatura gay, sobre todo en lo referente a la narrativa de iniciación o historias donde un determinado personaje asume su disidencia sexual. No obstante, conforme el protagonista va internándose dentro del gueto, advierte su "anormalidad" como un hecho no privativo de su persona, sino concerniente a una gran cantidad de individuos, situación que apoya, en buena parte, su autoconocimiento y valoración, disolviendo paulatinamente la paradoja inicial: "Si sus revelaciones tendían a lastimarme [se refiere a las confesiones de Pedro Alvarado sobre el amor
} 
contacto sexual hayan creado una familia institucionalizada, con hijos y permanentes apariencias, muy diferentes al estilo de vida de Novo, pero, en un primer momento, gozaron -o continuaron gozando- de una sexualidad diversa de forma subrepticia.

La concepción homoerótica y demás experiencias de Novo no quedan solamente en la niñez. En un acto de verdadera valentía y atroz verosimilitud, el narrador de La estatua de sal continúa su relato ya no en las calles del norte del país, sino en la capital. El ansiado regreso del joven Salvador a la Ciudad de México es cumplido en 1917 y, con este evento, inicia un nuevo recorrido por una sexualidad más vibrante. Esta segunda parte reitera lo hasta aquí dicho sobre el carácter pionero del texto de Novo dentro de una historia de la disidencia sexual mexicana: La estatua de sal confiere luz al gueto y menciona personajes, tiempos y espacios homoeróticos ocultados. Al respecto, Juan Carlos Bautista menciona lo siguiente: "En esta crónica autobiográfica no hay compasión ni solidaridad, es cierto, y los personajes son expuestos con crudeza, con una ironía que se ejercita contra todos y ante todo, incluso contra sí mismo". ${ }^{81} \mathrm{Y}$, en el mismo sitio, con denotada exaltación acota: "Pero ¡qué estilo admirable, qué crueldad deliciosa, qué voluntad de verdad (esa intensa, exagerada, voluntad de verdad que ha animado la literatura homosexual) insufla estas páginas y hace creíbles y vívidas sus descripciones!" ${ }^{\prime 2}$ Estas afirmaciones coinciden plenamente con el carácter revelador de la segunda parte de La estatua de sal, en cuya historia hay un deliberado anhelo de denuncia de los otros, no a modo de infligir un castigo debido al latente deseo homoerótico, sino usado para calificar la disidencia sexual como un hecho que permea todos

tenido por éste hacia otros jóvenes], no lo lograron. Su resultado fue que mi admiración, mi sorpresa, se confortaran en la comprobación de que mi pecado era menos singular que como hasta entonces lo concebía. Me alegra que hubiera otros muchachos como yo". Ibid., p. 141.

${ }^{81}$ Bautista, "La noche al margen. Brevísima relación de la vida nocturna gay", pp. 214-215.

${ }^{82}$ Loc. cit. 
los estratos de la sociedad mexicana. Hay, probablemente, en esta táctica un modelo incipiente -utilizado más tarde por los movimientos de liberación sexual- de marcar la homosexualidad como un hecho extendido entre la población, es decir, la nulidad de la pretendida minoría disidente establecida por el discurso hegemónico. Novo busca, de este modo, señalar la evidente institucionalidad de un deseo heterosexual, pero, al mismo tiempo, la clara incidencia de una generalizada ruptura con el mismo. ${ }^{83}$ Prueba de ello son sus andanzas por diversas casas de encuentros masculinos -muy similares a las de Cotita de la Encarnación y Señora la Grande durante la época novohispana-, donde, de forma alegórica, podría advertirse la clandestinidad del gueto en correspondencia con una hegemonía heterosexual implacable. Esto también le permite adjudicarse el código de identificación del gueto homosexual instalado, irónicamente, en Madero, epicentro de la vida capitalina:

Descubierto el mundo soslayado de quienes se entendía con una mirada, yo encontraba aquellas miradas con sólo caminar por la calle: la avenida Madero, por la que entonces la gente paseaba lentamente todas las tardes. Allí, en guardia a la puerta de El Globo, estaba siempre, con su bastón, sus polainas, su chaleco de seda, la mirada vaga y alerta de su pince-nez, sus bigotes grises aderezados, el señor Aristi, a quien llamaban la Nalga que Aprieta; por la puerta de junto al Globo se subía al despacho del licenciado Solórzano - de quien contaba Ricardo que en su casa cantaba arias de la ópera (Ninon, Ninon qu'as-tu fait de la vie), y al que apodaban la Tamales, porque hacía sus conquistas invitando a los jovencitos a merendar "unos tamalitos y una cerveza". Por ahí andaba, a caza de clientela o de surtido, la Madre

\footnotetext{
${ }^{83}$ Ejemplo de ello es el sorpresivo descubrimiento, para el narrador, del homoerotismo dentro de la milicia mexicana: "Ya para marcharme, aturdido aún por las revelaciones de Pedro, le pregunté si también aquel militar que estaba con él en la esquina -y entonces él colmó sádicamente mi asombro al expresar que sí, que ese militar también, y que iría yo comprobando cómo los militares, particularmente, se inclinaban por acostarse con los hombres [...] Pero esto de los militares no era posible [...] todos ellos un clan aparte de la sociedad y por ende sin duda libres de sus decadencias". Novo, La estatua de sal, p. 142. $\mathrm{El}$ prestigio de la milicia hace prácticamente increíble que alguno de sus miembros tengo algún deseo homoerótico. Nuevamente, la señalada paradoja de Marquet se reitera en este asombro de Novo y deconstruye el andamiaje sexual normativizado y clandestino de la sociedad mexicana.
} 
Meza -que nunca se acostaba con la mercancía que procuraba para sus compradores, supervivientes refinados del porfirismo. Abordaba a los muchachos, los inducía a aprender a tocar la guitarra, que se ofrecía a enseñarles gratuitamente- y una vez en su cuarto tomaba con una cinta métrica la medida de su verga, y les abría las puertas de una circulación perentoria, pero inmediatamente lucrativa, entre sus contados y ricos clientes. ${ }^{84}$

Hay, en el texto de Novo, dos posturas homoeróticas bastante contrastadas que, hasta la actualidad, pueden observarse en México. Por un lado, están los practicantes de encuentros furtivos: sujetos con una identidad en apariencia masculina, cuya disidencia sexual es manifiestada de forma soterrada. Por otro, puede hallarse a los conformadores más estentóreos del gueto, a quienes el ojo seudoclínico de la sociedad de los años veinte identifica bastante bien. Las dos representaciones de individuos están emparentadas por el deseo homoerótico, mas no por un revestimiento genérico: los primeros hacen uso de una cotidiana virilidad, mientras, los segundos, no dudan en evadir esta pesada carga y actúan como mejor les plazca. No se trata tampoco de implantar aquí una taxonomía, sino de indagar en las posibles caracterizaciones del homoerotismo en el país durante las décadas relatadas por Novo. Así, el joven narrador distingue claramente estos dos tipos de personajes y juega con su representación. El primer tipo de sujetos, los enmascarados detrás de una capa de masculinidad, realizan una vida ajustada a las indicaciones del dispositivo de género; sin embargo, en la medida de lo posible, acceden a la sexualidad vetada con amplias precauciones para evitar cualquier descubrimiento. Los segundos, por el contrario, aunque en algún momento pueden temer el rechazo, exhiben su sexualidad y "desliz genérico" sin

\footnotetext{
${ }^{84}$ Novo, La estatua de sal, p. 163.
} 
pudor. Mucho tiempo estos individuos estuvieron asociados con el modelo del dandy: ${ }^{85}$ "Según Miguel Capistrán, Novo le dijo que entre los gays había (como hasta hace poco) un código tácito en la manera de vestir: pantalón y zapatos blancos, peinado relamido, etcétera" ${ }^{86}$ Y, más adelante, Bautista denota la contigüidad con el modelo social señalado: "Estaba, por supuesto, la influencia en esos años del dandismo. Los dandis, que según Baudelaire, debían vivir y dormir frente a un espejo. El dandi es un artista a su manera, 'su vida es su obra de arte', decía Jules Lamaitre. Los dandis mexicanos lo eran a su modo, un modo aristocrático en un país que ha sido secularmente arrasado por el racismo y el sexismo". ${ }^{87}$ Estos dandis son ampliamente conocidos en México, especialmente dentro de las grandes ciudades, y su figura ineludiblemente es asociada con el desliz sexual ¿cómo un hombre, en la "plenitud de su revestimiento genérico masculino", podría comportarse de tal forma y poner el acicalamiento diario por encima de otras actividades? ¿Acaso esta preocupación no debería pertenecer a una "natural" correspondencia con el afeminamiento? Y, a partir de estas cuestiones, inicia la crítica al comportamiento genérico, es decir lo simplemente observado, para indagar de modo insidioso en la conducta sexual del individuo en análisis. Aquí radica uno de las principales directrices de la sexualidad hegemónica: la correspondencia inamovible entre el sexo, el género y el deseo. Por ello, a todo comportamiento "anómalo" en lo genérico debe corresponder un hecho igual en el ámbito sexual. Y Novo pone muy bien en práctica este salvoconducto cuando se sorprende por la conducta homoerótica de la milicia ¿cómo un hombre correctamente masculino y

\footnotetext{
${ }^{85}$ Cuya traducción, en la actualidad, es la imagen del sujeto amante de su imagen y muy acicalado, al cual corresponde la visión casi institucionalizada del "gay": individuo de hermoso aspecto, buenos modales, amplio poder económico y con un dominio absoluto de la moda masculina.

${ }^{86}$ Bautista, "La noche al margen...", p. 215.

${ }^{87}$ Loc. cit.
} 
representante, además, de los valores más intrínsecos de la patria puede prestarse a una situación pecaminosa y abyecta? No obstante, después de esta espléndida y amigable sorpresa, el autor deconstruye otras identidades que, en el imaginario social, no estarían imbricadas con la homosexualidad, como los policías, choferes, obreros y demás oficios y profesiones cuya rectitud sexual forma parte casi fundacional de la nación. Parece haber un guiño aquí con la novela de Castrejón, Los cuarenta y uno, en la cual el autor ataca ferozmente a la aristocracia mexicana, corrupta en sus vicios y plena de ambición, cuya contraparte, la clase popular trabajadora, debe aniquilar para establecer un país libre de sexualidades nefandas. Novo, por el contrario, mediante muchas experiencias placenteras, desdice este supuesto con fehacientes pruebas y pone muy en claro el deseo homoerótico como algo no ligado a una representación genérica ni social -y mucho menos de profesión, sino como un acontecimiento cotidiano de las pulsiones humanas, cuya necesidad no obedece a un estratagema heteronormativo, estableciendo con ello la ruptura entre el sexo, el género y el deseo.

La importancia entonces de La estatua de sal consiste en brindar al lector el amplio panorama del homoerotismo durante las primeras cuatro décadas del siglo XX. Desde el recuerdo de los primeros años en la Ciudad de México, pasando por la niñez vivida en el norte del país y de vuelta al Distrito Federal, ya en la adolescencia, Novo articula una verdadera epopeya de la disidencia sexual. Realiza un gran acercamiento al gueto homoerótico, pero no se queda solamente en él, sino que explora, a través de su escritura y experiencias personales, la latente presencia de la homosexualidad en todos los niveles de la 
sociedad mexicana. ${ }^{88} \mathrm{Y}$, mediante este recorrido, hace también una apología del modelo de sexualidad mediterránea instalado en México, como páginas atrás se había ya mencionado.

Como se advierte, este estadio histórico recogido en la autobiografía del poeta es heredero, en primer lugar, de la tradición del "sodomita" novohispano; después, de la imagen decimonónica del "afeminado" o "invertido"; y, por último, atrae para sí la formulación del dandismo tan en boga durante el porfiriato. En esta primera mitad del siglo pasado, convergen todos estos enfoques de la disidencia; no obstante, hay, a la vez, una clara visión del estatuto médico-judicial del homosexual recogido del discurso higienista europeo, que fue importado en México mediante las doctrinas positivistas y el continuo "afrancesamiento" de la sociedad efectuado hasta antes de la Revolución. Sin embargo, con la visibilidad tenida por la generación de los Contemporáneos, se produce un nuevo ajuste para las identidades homoeróticas, al grado de que, para Carlos Monsiváis, se trata de la primera gran exhibición de la homosexualidad en México, y Novo, mediante La estatua de sal, resume maravillosamente esta difícil "salida de clóset". A partir de este momento, y con el puntual antecedente del baile de 1904, la visibilidad de la disidencia será prácticamente irrefrenable.

Durante los años posteriores, especialmente los correspondientes a la década de 1950, hay una segunda manifestación del gueto homosexual del país, a la que Monsiváis denomina como "la segunda generación de gays". Esta nueva cofradía está marcada por una "red de amistades y conocencias (el gueto) [que] es lo bastante amplia como para aminorar los hostigamientos y asegurar la visibilidad primera". ${ }^{99}$ No obstante, a pesar de reconocerse

\footnotetext{
${ }^{88}$ La siguiente cita reitera lo aquí planteado: “Algunas veces solía también aparecer por el estudio la figura regordeta y miope de Genaro Estrada, entonces oficial mayor de Relaciones y más tarde ministro y embajador de México, para lo cual hubo de casarse. Desde su puesto en Relaciones facilitaba discretamente el ingreso en el honorable cuerpo diplomático y en el consular, de las loquitas jóvenes y de buenas familias que buscaban su patrocinio."

${ }^{89}$ Monsiváis, Que se abra esa puerta, p. 126.
} 
dentro de un grupo, los homosexuales de la época padecen terriblemente el desprestigio social y, no pocas veces, agresiones físicas e, incluso, asesinatos. ${ }^{90}$ Cabe mencionar la continuidad de la figura de Salvador Novo durante estas fechas -recuérdese su muerte acaecida en 1974-, cuya presencia es casi un eslabón entre la visibilidad homosexual de los Contemporáneos y la enardecida avanzada de los movimientos de liberación sexual en la década de los setenta. El enclave de Novo es, así, la punta de lanza y ruptura del gueto para mostrar cómo la diversidad comienza a sacudir las conciencias más herméticas.

Monsiváis, en “Los gays en México: la fundación, la ampliación, la consolidación del gueto", advierte los elementos más característicos de esta segunda muestra de la disidencia sexual. Entre estos señala al bolero como uno de los medios más eficaces que constituyó, subrepticiamente, una incipiente cultura "gay". Esta música que acompañó a numerosas películas del cine nacional sirvió también como portavoz de las más elocuentes formas de amor homosexual. El bolero fundó en la "segunda generación de gays" -algunas veces de forma no deliberada y, otras, de un modo más directo- un verdadero catalizador de las emociones vividas al margen. Canciones dedicas a prostitutas o lamentos de mujeres debidos a la pérdida del amado son adoptadas, instantáneamente, por una comunidad condenada al más absoluto de los silencios. ${ }^{91}$ También, caben en este rubro boleros que rozan la ambigüedad del género o plantean una relación afectiva en una situación heterodoxa respecto de una hegemonía amorosa ¿Cómo explicar, en términos bastante maniqueos, el adecuado

\footnotetext{
${ }^{90}$ Cabe destacar que, a pesar de los grandes cambios observados en la sociedad mexicana durante las últimas décadas sobre la visión tenida respecto de la diversidad sexual, el desprestigio y los crímenes de odio son persistentes. Si bien es cierto una notable apertura respecto de las condiciones sociales de esta "segunda generación de gays", la inmanencia de la homofobia en sus más intrínsecas representaciones es insoslayable.

91 Para dar un ejemplo de esta situación, baste rememorar cómo, en cualquier bar dedicado a la comunidad queer mexicana, siempre se dan cita canciones como "Luces de Nueva York", "Perfume de gardenias", "Amor de cabaret", "Perdida", "Amor perdido" e "Hipócrita", entre muchas otras.
} 
contexto vivencial de una relación de pareja si éste apela a lo prohibido, al pecado, a la culpa o a un mundo raro de tentaciones? Esta pregunta la reitera Monsiváis cuando realiza un acercamiento a diversas canciones consideradas fundamentales dentro de la llamada cultura gay mexicana:

\begin{abstract}
A los opera queens se añaden, en una dimensión casi siempre complementaria, los fans del bolero, un género valorado por su calidad melodramática y su vocación de exceso. Allí se declara lo que difícilmente admiten las conversaciones. [...] El efecto de los boleros se potencia en escenarios propicios a la dicha del melodrama: cabarets, departamentos a la luz de la madrugada, casas de vecindad. [...] A lo mejor se alude a un adulterio que alcanza el ateísmo por amnesia, pero lo probable es que se trate de un affair gay. [...] Los sueños tristes de este amor extraño... La idea de filtrar lo gay calificándolo de mundo raro o de "amor extraño" (lo queer), es una de tantas estrategias para decir la verdad. Entonces, la marginalidad busca institucionalizar lo inesperado. [...] En una cultura machista ¿tiene sentido que un hombre se dirija así a una mujer? La canción sólo se aclara si un hombre se la dedica a otro. ${ }^{92}$
\end{abstract}

La ambigüedad en el género del sujeto interpelado, el contexto heterodoxo de la relación amorosa o el simple lamento de la pérdida del amado son los detonantes, mayoritariamente, que convierten a una canción dada en un espacio catalizador de los deseos homosexuales. ${ }^{93}$

\footnotetext{
${ }_{92}$ Monsiváis, Que se abra esa puerta, pp. 130-132.

93 Pável Granados menciona al respecto cómo el amor homosexual es encubierto en el bolero mediante una estrategia de no nombrar al sujeto amado, generando sólo la idea del amor sin dirigirse a un componente genérico: "Por ello, se toma la decisión de encarnar el amor homosexual en "dos seres que se aman", algo que nadie reprocharía puesto que sólo pueden amarse los sexos contrarios. Afortunadamente, la censura sólo ve lo más concreto y cualquier símbolo es posible siempre y cuando no tenga repercusiones en lo inmediato. Por eso la censura baila al ritmo de los boleros asexuados y les permite su existencia, ya que no concibe otro tipo de relación ni los supone vehículos de nada más allá que del amor burgués. Si dos hombres se dan cita dentro de un discurso amoroso (sitiados por la censura), deben procurar que sólo los elementos neutros se asomen al fenómeno". Pavel Granados, "Un grito aquí en la sangre (reflexiones sobre la obra de Gabriel Ruiz)", en México se escribe con J, p. 203.
} 
Los años cuarenta y cincuenta proveen así un corpus extenso de boleros usados emblemáticamente por la comunidad queer mexicana. No obstante, como ya se había mencionado que si bien estos años son profundamente ricos en cuanto a la construcción de una "gaydad" mexicana se refiere, la situación no es privativa de la época. Los años anteriores y, por supuesto, los subsecuentes han nutrido la música usada como estandarte por la comunidad homosexual, aunque, sin duda, el bolero de canciones asexuadas es una de las máximas expresiones de la misma.

En cuanto a la literatura se refiere, los únicos que habían osado transgredir las barreras del dispositivo de la sexualidad mexicano eran algunos integrantes de los Contemporáneos; sin embargo, en la década de los cincuenta y sesenta, sobre todo, ${ }^{94}$ hay ya otros textos, principalmente en narrativa, cuya diégesis apela a la disidencia sexual. Al parecer, la brecha abierta por la generación de Novo, Villaurrutia, Pellicer y Nandido, permite ya una mayor permisividad en cuanto a la exhibición de una sexualidad heterodoxa. Al respecto, Marquet señala la importancia de la novela del autor italo-mexicano Carlo Cóccioli titulada Fabrizio Lupo, publicada originalmente en francés en 1952 y, posteriormente, traducida al español por Aurelio Garzón del Camino y editada en México por la Compañía General de Ediciones en 1957. Para Marquet este texto es un sitio ineludible de una tradición literaria homoerótica

\footnotetext{
${ }^{94}$ Mario Muñoz, en el prólogo a su antología De amores marginales, sostiene que "Respecto de la temática gay, durante un tiempo considerable, la literatura mexicana soslayó su existencia al dejarse llevar por el pudor, y también este silencio debe atribuirse a las reticencias morales sobre este asunto. En todo caso, las escasas aportaciones que había sobre el tema parecían indicar que éste no formaba parte del amplio registro de realidades de que se han nutrido nuestros escritores. Lo cierto es que hasta la década del sesenta comienzan a aparecer con amplia difusión las primeras novelas que abordan con franqueza el conflictivo ámbito de la homosexualidad". Mario Muñoz, De amores marginales (México: Universidad Veracruzana, 1994), p. 14.
} 
mexicana que, a pesar de haber sido escrito originalmente en otra lengua, tiene un enorme impacto en el país debido a los fuertes lazos establecidos por Cóccioli con México. ${ }^{95}$

No obstante, es, sin lugar a dudas, la década de los sesenta la que impulsa mayormente la tradición literaria homoerótica en narrativa.${ }^{96}$ Las novelas que sostienen dicha afirmación son El diario de José Toledo (1964) de Miguel Barbachano Ponce, 41 o el muchacho que soñaba en fantasmas (1964) de Paolo Po y Después de todo (1969) de José Ceballos Maldonado -probablemente, los más conocidos de estos tres textos resulten el primero y el último, dada la poca crítica existente sobre la obra de Paolo Po-. Para Luis Mario Schneider El diario... es el texto fundacional de la novela mexicana de contenido homoerótico: Este hecho estaría justificado por considerar a Los cuarenta y uno de Castrejón como un texto panfletario con poco valor literario, por la nacionalidad del autor y el idioma original en el que fue escrito Fabrizio Lupo y, en última instancia, por el abordaje subrepticio del tópico en El norte de Carballido. De este modo, la novela de Barbachano ocuparía su lugar como pionera y, además, tiene el mérito de abordar la homosexualidad directamente e, incluso, de recurrir a soslayadas descripciones de escenas sexuales, ${ }^{97}$ cuya "impudicia"

95 "Italiano de nacimiento, Carlo Cóccioli nació en Livorno en 1920. A los treinta y tres años, en 1953, se estableció en México [...] Murió [...] el 5 de agosto de 2003.[...] Habría que agregar que México fue también el país donde murió con el sentimiento de haber estado proscrito del reconocimiento oficial con la condecoración del Águila Azteca que sin duda merecía su labor literaria y periodística. Es preciso señalar que el autor modificó la ortografía de su nombre en México para que se pronunciara como esdrújula, razón suplementaria para incluirlo dentro de la literatura nacional". Antonio Marquet, "Castrejón Cóccioli y Novo: La novela gay en la primera mitad del siglo XX".

${ }^{96}$ Más adelante, se verá de forma amplia y específica el camino seguido por el homoerotismo en el cuento mexicano de dicha época. En estas páginas se realiza solamente un sucinto recorrido por la incipiente novela de contenido homosexual con el fin de ilustrar más el objetivo de este capítulo.

${ }_{97}$ Algunos de los fragmentos referidos son los siguientes: "entonces esperaré con verdadera ansia el día en que nuestros cuerpos vuelvan a estar juntos en son de una luna de miel diferente a las anteriores"; "estuve parado frente al edificio un buen rato, vi llegar a tu papá, serían cerca de las nueve y media cuando entré al lugar donde tantas veces nos besamos y nos la hicimos; claro está que al recordarlo yo mismo me la hice y no sabes cuánto gocé al imaginar que estaba cerca de ti"; "yo estaba enamorado de su cuerpo y cuando nos denudábamos enloquecía, me fascinaba porque era velludísimo, no tenía un solo lugar en el cuerpo sin vello, parecía colchón”. Miguel Barbachano Ponce, El diario de José Toledo (México: Era, 1964), 
seguramente trastrocó a varios de sus lectores que poco, o mejor dicho en nada, estaban acostumbrados a textos de dicho calibre. ${ }^{98}$

La novela de Barbachano aquí citada aborda el padecimiento sufrido por José Toledo, un joven burócrata, quien vive absolutamente enamorado de Wenceslao, su pareja amorosa. A lo largo de la narración, José Toledo cuenta a su diario cómo ha vivido la pasión, el cariño, los celos y el dolor por la pérdida de su amado, al lado del cual ha tenido casi un año de dicha plena interrumpido por la abrupta partida de este último. Así, con base en la ausencia, Toledo hace un recuento de su vida pasada, en compañía de Wenceslao, y la presente, aderezada por la falta de él. Sin embargo, más allá de la relación mantenida por estos dos personajes, hay un discurso verdaderamente asombroso sobre la forma de vida y ligue homosexual en el Distrito Federal: la ciudad se erige en el texto como un campo propicio para dichas prácticas, donde, con pequeños ajustes de ocultamiento con el objetivo de evitar la sanción social, los personajes de El diario... viven a plenitud su amor y sexualidad. El "ambiente" de la década de los cincuenta $^{99}$ aparece muy aludido por el narrador, quien describe el modo de relacionarse con Wenceslao a través de las calles de la ciudad. Además, para complementar esta imagen, en un plano paralelo José da a conocer al lector los diversos momentos en que

pp. 36, 53 y 62, respectivamente. Como se observa en estas citas, aún la forma de hablar del cuerpo es con precaución: si bien hay una claro señalamiento a la conducta erótica de los personajes, no hay la descripción detallada de un encuentro sexual. Toledo se refiere al cuerpo de Wenceslao para resaltar su hermosura, pero nunca acota con precisión alguna parte determinada del mismo. A pesar de estos cuidados, es evidente que para el lector contemporáneo de El diario... estos fragmentos sacudieran un poco su visión del mundo, tanto desde un aspecto de empatía como de rechazo.

${ }^{98}$ Debe recordarse aquí que, debido a la publicación muy posterior de La estatua de sal, pocos lectores tuvieron a acceso a los manuscritos de Novo en dichos años, en los cuales el contenido homoerótico explícito es más "fuerte" en comparación con El diario de José Toledo.

${ }^{99} \mathrm{Si}$ bien la novela fue escrita en 1962 y publicada en 1964, la diégesis de la misma está situada a finales del decenio anterior: "El burócrata José Toledo, de veinte años de edad, se tiró de la azotea del edificio número 60 de las calles de Simón Bolívar en la colonia Asturias [...] Un día de agosto, meses antes de que te suicidaras, comenzaste a escribir un diario [...] El veintisiete de octubre de mil novecientos cincuenta y ocho extraviaste el diario en un camión de segunda clase". Barbachano, El diario de José Toledo, pp. 7 y 126 , respectivamente. 
él mismo resulta asediado por otros jóvenes y el modo de seducción operados por este último. ${ }^{100}$

Sobre la aceptación o rechazo de la disidencia sexual hay una serie de percepciones entrecruzadas de los personajes. Por un lado, José vive su deseo y amor sin complicaciones y sólo en una ocasión menciona la "culpa de tener un amor que no corresponde a una persona normal". ${ }^{101}$ El mismo diario del protagonista es una exaltación del homoerotismo y de la búsqueda y conservación de la pareja: para José no es tan importante la sanción moral o el vivir de manera subrepticia, lo primordial es encontrar la felicidad junto a Wenceslao. ${ }^{102} \mathrm{Y}$ es en este último personaje en el cual se da cita una serie cuestiones relacionadas con la experimentación erótica que van desde el travestimiento hasta un deseo heterosexual. Para Wenceslao, José no adquiere la misma importancia e, incluso, lo utiliza como proveedor de insumos económicos. En el caso de este personaje, sería bueno recordar lo dicho por Judith Butler en Mecanismos psíquicos del poder sobre la interiorización de la norma: la preeminencia de la heterosexualidad como entidad de dominio absoluto respecto de los deseos y estatutos genéricos del individuo ha sido tal que, cuando éste comienza a explorar

\footnotetext{
100 Cabe mencionar la proclividad de Toledo con respecto al bolero. El protagonista aparte de escucharlo, sobre todo en las interpretaciones de Libertad Lamarque, intenta escribir alguno con base en la nostalgia producida por la falta de Wenceslao. Esta situación puede enlazarse con lo dicho anteriormente sobre el medio de comunicación en clave homoerótica que proporcionó dicho género musical durante varias décadas no sólo en México, sino en toda Hispanoamérica. Un ejemplo de esto último es la continua remembranza de las letras de boleros por parte de Molina mientras se encuentra en la cárcel, al lado de Valentín, en El beso de la mujer araña de Manuel Puig. Podría decirse, no sin temor a objeciones, que El diario... es un largo bolero melodramático, desesperado y trágico sobre la situación del homosexual en México a mediados del siglo XX.

${ }^{101}$ Barbachano, El diario..., p. 86.

102 En un momento de ansiedad del amado ausente, Toledo expresa: " $Q Q u e ́$ daría por besarte y abrazarte aunque la gente nos viera!" Barbachano, El diario..., p. 93. Esta frase refuerza la magnitud del amor del protagonista, cuya importancia absorbe cualquier precepto moral y, en dado caso, podría enfrentarlo de lleno con la sanción de su colectividad. Otros sucesos ignorados por José mientras permanece en el anhelo continuo de Wenceslao son las protestas sociales llevadas a cabo, sobre todo, en el centro de la ciudad. La maestría narrativa del autor se hace palpable en este hecho cuando evidencia la abducción de Toledo en el epicentro de las marchas y los disturbios.
} 
"otros territorios" en busca de su satisfacción, experimenta cierto rechazo hacia lo considerado fuera del paradigma, aunque en este tránsito deba aniquilarse a sí mismo. Wenceslao padece esta situación aunada a una inestabilidad económica y afectiva que lo lleva a alejarse del seno familiar en una fingida búsqueda de trabajo, pero el motivo de la partida no es este, sino un apetito de ruptura con el entorno, donde se halla el desprecio hacia sus padres, el hartazgo emanado de su relación con José y los embates entre su disidencia sexual y el dispositivo hegemónico de la misma.

Por otro lado, los únicos personajes que advierten la relación amorosa entre Toledo y Wenceslao -y, de paso, su aparente "anormalidad"- son la madre del primero y el padre del segundo. Para ambos, la conducta de sus respectivos hijos no es la adecuada; sin embargo, con el objetivo de procurar su felicidad y la propia, la madre de José evita cualquier elucubración al respecto e intenta obviar los "raros" comportamientos del protagonista; mientras el padre de Wenceslao, en un plano menos afectivo y más monetario, observa con buenos ojos la relación entre su hijo y Toledo, siempre y cuando este le proporcione a Wenceslao el dinero suficiente durante el tránsito de hallar mejor fortuna.

El diario... evidencia, entonces, un estadio histórico de la concepción de la disidencia sexual a mediados del siglo pasado: sorprende por su manejo directo de la situación y, en consecuencia, provee al lector de una postal muy nítida del binomio aceptación/rechazo padecida tanto por el sujeto homosexual como por su familia. ${ }^{103}$ No obstante, a pesar de encumbrar al amor homosexual, la historia de la novela no olvida la transgresión y el fin de

\footnotetext{
${ }^{103}$ Sobre la diégesis y proceso creativo del texto, Victor Federico Torres comenta: "El anonimato y la clandestinidad como única salida para el homosexual son aspectos dominantes en El diario de José Toledo. Según expresó el propio autor, en una entrevista publicada en la Revista Mexicana de Literatura Contemporánea, la historia es verídica, ya que encontró el diario en el mercado de Tepito". Víctor Federico Torres, "Del escarnio a la celebración. Prosa mexicana del siglo XX", en México se escribe con J, p. 90.
} 
Toledo - como ocurre en textos anteriores al de Barbachano- es la muerte, provocada en este caso mediante el suicido. Por esta razón, hay en El diario... una enorme paradoja entre la exaltación del amor "marginal”, cuya grandeza es reiterada a cada momento por el narrador, y la incapacidad de supervivencia del mismo en una sociedad heterosexista: la búsqueda de la pareja - en una clara apelación al matrimonio hegemónico- y la destrucción de ella, debido a la inconveniencia sexogenérica de los implicados, es el gran leitmotiv de buena parte de la narrativa homoerótica.

Justamente a finales de la década de los sesenta, el 28 de junio de 1969, se produce en un barrio de Nueva York, el Greenwich Village, un motín cuyas repercusiones se extenderían por todo el mundo occidental y cambiarían la forma de concebir la disidencia sexual. Se trata de la famosa redada efectuada por la policía en el bar Stonewall; sin embargo, el hecho hubiera pasado desapercibido a no ser por la enérgica respuesta de los agredidos, homosexuales y travestis, quienes a causa de los atropellos sufridos, y en manifestación de su hartazgo por los mismos, deciden enfrentarse a la policía y visibilizar sus preferencias. Este acontecimiento trajo varias consecuencias agradables en pro de la disidencia sexual. En primer lugar, el contraataque de los ofendidos funciona, a manera de alegoría, como una forma de ruptura con el orden establecido y una demostración de la unidad y la lucha en favor de la flexibilidad del paradigma sexual: lo que en otro tiempo habría sido sumisión y encarcelamiento, ahora es la defensa del derecho a la libertad de elección. En segundo término, el eco de los disturbios generados trabajo consigo la creación de varios grupos en pro de la liberación sexual, como el Gay Liberation Fort y el Gay Activists Alliance. Por último, para conmemorar el motín del Stonewall se decidió hacer una marcha al año siguiente por las calles de Nueva York, Los Ángeles y Chicago; en los años subsecuentes, se unieron 
a dicha celebración varias ciudades del mundo con la misma demanda y, hasta la fecha, la conmemoración prosigue.

Monsiváis menciona la importancia de estos motines, pero señala también la repercusión un poco tardía tenida en el país: “A México, las noticas de Stonewall llegan tarde y sin énfasis, pero ya en 1971 la dramaturga y directora de teatro Nancy Cárdenas convoca en su departamento a las reuniones de concientización (a la manera de los awarenees groups de Estados Unidos) donde los asistentes relatan sus experiencias con "el numerito" (el come out personal) y discuten materiales de Estados Unidos e Inglaterra". ${ }^{104}$ En México, el movimiento de liberación gay iniciado a principios de los setenta no está nutrido solamente de ideas provenientes del exterior, sino que está fuertemente influido por diversas consignas del, para entonces reciente, movimiento estudiantil de 1968. Las propuestas de cambio emanadas de dicho trance histórico están aún frescas y, además, numerosos participantes del mismo promueven la sed libertaria. Baste recordar que la primera marcha en defensa de los derechos de la disidencia sexual se efectuó en octubre -y no en junio como pudiera pensarse en correspondencia con los disturbios de Stonewall- de 1978, al lado de la conmemoración del décimo aniversario de los lamentables sucesos acaecidos en Tlatelolco. Sobre la incidencia del movimiento estudiantil del 68 en los inicios de la reivindicación de la disidencia sexual en México, Marquet menciona:

La cultura gay, tal como la conocemos actualmente, debe mucho al movimiento del 68. Cobró fuerza con el mayor pronunciamiento en favor de la liberalización del sombrío puritanismo decimonónico que haya conocido este siglo, con lo cual dejó atrás ciertos estilos alusivos, catecúmenos, que tenían casi todas sus manifestaciones. [...] Ciertamente el 68 no cambió al mundo. No cristalizó en una revolución.

104 Monsiváis, Que se abra esa puerta, p. 156. 
Sin embargo, la exigencia de libertades y esa vocación suya de "reformismo" (término no exento de cierta devaluación que pretende mitigar sus alcances), logró una transformación quizá más lenta, aunque sin duda mucho más profunda e innegablemente mucho más íntegra: la liberación de las mentalidades, la relajación de la tiesa vida cotidiana, de la hegemonía familiar que se encontraban cómodamente arrellanadas en un esquematismo jerárquico y maniqueísta. "Exigir lo imposible" para los homosexuales de la sociedad represora pre-68 consistía de alguna manera en lo que vivimos ahora. ${ }^{105}$

Aunado a los ecos del movimiento estudiantil de 1968 y del motín de Stonewall, en 1971 acontece una situación que detona aun más los ya enardecidos ánimos libertarios: el despido de un trabajador de una tienda Sears por demostrar una conducta homosexual. Salinas Hernández al respecto dice: "Este hecho provocó la reunión de intelectuales, artistas y estudiantes, principalmente ligados a la Facultad de Filosofía y Letras de la Universidad Nacional Autónoma de México, para discutir en torno a posibles acciones de respuesta frente a lo que consideraron un acto de homofobia". ${ }^{106}$ De este modo es inaugurada una de las décadas más agitadas en México en cuanto a liberación sexual se refiere, en la cual aparecen las primeras organizaciones de lucha en favor de los derechos de los homosexuales, “promovidos y apoyados por algunos intelectuales como Nancy Cárdenas y Carlos Monsiváis". ${ }^{107}$

En 1971 es fundado el efímero, pero profundamente incisivo para los años subsecuentes, Frente de Liberación Homosexual que desapareció un año después. Más adelante, en 1974, aparece el grupo Sex-Pol; el Frente Homosexual de Acción Revolucionaria cobra vida en 1978 y, en este mismo año, aparece el Lamba. Durante estos

105 Marquet, iQue se quede el infinito sin estrellas!, pp. 15-17.

106 Hector Miguel Salinas Hernández, Políticas de disidencia sexual en América Latina. Sujetos sociales, gobierno y mercado en México, Bogotáy Buenos Aires (México: Eón, 2010), p. 80.

107 Idem., p. 80. 
años, surgieron grupos dedicados exclusivamente a la visibilidad y lucha por las lesbianas, que, como bien lo menciona Salinas Hernández, no encontraron demasiado apoyo en la Coalición Nacional de Mujeres: ${ }^{108}$ en 1974 nace la organización Ácratas, en 1977 el grupo Lesbos y, hacia 1978, surgen el Oikabeth y el Clóset de Sor Juana. La labor primigenia de estas organizaciones trajo para México una verdadera renovación de los paradigmas sexuales tenidos hasta entonces. Si bien el cambio no ocurrió en cuestión de días, su lucha constituyó el inicio de una insondable ruptura dentro de la sociedad mexicana. ${ }^{109}$

Este proceso de cuestionamiento de la sexualidad hegemónica no es privativo del ámbito social: el cine, uno de los discursos artísticos más difundidos en el país, realiza lo suyo con varias cintas cuyo tema apela al ámbito del homoerotismo, pero no desde la perspectiva de la denigración, sino del planteamiento de la disidencia sexual como un hecho "natural” y cotidiano del hombre. Esta bifurcación la señala claramente Bernad Schulz-Cruz en Imágenes gay en el cine mexicano, en el cual articula un enorme corpus que va de la década de los setenta y llega hasta finales del siglo pasado. Schulz-Cruz plantea la existencia paralela de dos tipos de cine de contenido homoerótico: el primero aborda la figura del "maricón" o el "joto" como un ser despreciable, y cuyo único objetivo dentro del espacio social de la película dada es causar risa y, a la vez, lástima; el segundo es, para Schulz-Cruz, más "constructivo" porque conduce al espectador por la caracterización "humana" del personaje homosexual. El primer tipo de cine ha existido desde hace mucho tiempo en el país, incluso puede remontarse a la década de los treinta: "En el cine mexicano siempre ha habido una presencia de jotos en la pantalla que comienza en 1938 con La casa del ogro,

\footnotetext{
108 Idem., p. 82.

109 Monsivaís considera este suceso como una segunda eclosión de la visibilidad homosexual -que bien podría ser tercera tomando en cuenta la redada de 1901- si se recuerda la que el autor supone como inicial: la generación de los Contemporáneos en la década de los veinte.
} 
donde el personaje gay supuestamente agrega colorido, chispa y simpatía". ${ }^{110}$ A esta cinta, el investigador añade otras tantas que, con anterioridad, habían mostrado la figura del "joto" o, simplemente, tenían un ligero sesgo homoerótico como El cobarde (1938), Me ha besado un hombre (1944), A toda máquina (1951), ¿Qué te ha dado esa mujer? (1951) y Tintorera (1976). Sin embargo, el discurso cinematográfico que mayormente colocó la figura del "maricón" caricaturizada al extremo fue el clásico "de ficheras", cuyas historias siempre sostenían a brutalidad la conveniencia del sistema heterosexista, tanto desde el punto de vista erótico como de poder. Así, las mujeres-prostitutas en las películas "de ficheras" son objetos con los cuales los individuos masculinos se divierten y los "jotos" resultan simples asistentes de las primeras. En un orden de poder y visibilidad ciudadana, el homosexual en estas cintas aparece para denotar su propio lugar al margen de toda la matriz de identidades prestigiadas. Paradójicamente, las décadas de los setenta y ochenta -tan plagadas de movimientos en pro de las libertades sexuales- son en las que se filman la mayoría de estas películas.

Es evidente el objetivo de denostar al personaje homosexual por parte del cine "de ficheras", y el poco o nulo valor que en una conformación de un corpus homoerótico dentro del discurso señalado podrían tener, tal como lo señala Schulz-Cruz; no obstante, debe tomarse en cuenta dos particularidades: la denominada "cultura/arte gay" -y aquí cabría recordar los postulados de Antonio Marquet al respecto- no sólo incluye aquellas obras cuya meta es la exaltación del homoerotismo, sino a otras tantas que pudieran denigrarlo. Páginas atrás se había mencionado la novela Los cuarenta y uno de Castrejón para ejemplificar cómo un autor usaba el viejo recurso del desprestigio social mediante la "homosexualización" para atacar a la oligarquía porfirista. Del mismo modo, el cine "de ficheras" sirve para cimentar

\footnotetext{
${ }^{110}$ Bernard Schulz-Cruz, Imágenes en el cine mexicano. Tres décadas de joterio 1970-1999 (México: Fontamara, 2008), p. 19.
} 
el discurso hegemónico del género en México con el principio de la abyección de la mujer y del disidente sexual. Al respecto, Muñoz hace un claro recuento de las características y objetivos del cine "de ficheras" que bien vale la pena citar:

Hay que apuntar de entrada que este tipo de personajes [homosexuales] empezó a formar parte de la cultura de masas en el curso de los años setenta y a lo largo de los ochenta a través del cine comercial, que ha explotado su lado grotesco y caricaturesco para satisfacer así la imagen deformada del espectador corriente, que le hubiera parecido escandalosa e inadmisible esta temática de haberse tratado con la seriedad debida. [...] en las películas de cómicos y cabareteras es común que las "locas” y los travestis comparezcan como prototipos insustituibles de la farándula gay. Para que su presencia sea aceptada y asimilada como parte indispensable de una fauna urbana que pulula en las fronteras de lo tolerado y lo marginal, es decir, en el ambiente la barriada o de lupanar, estos engendros deben someterse a los sobajamientos de los que son objeto y mediante los cuales el macho, al mismo tiempo que afirma la potencialidad del falo, da rienda suelta a la subrepticia complacencia de sus inclinaciones feminoides. Peores que las putas, en cuanto a que su condición social es inferior a la de ellas, estos seres degradados que no encuentran sitio ni siquiera en este submundo donde imperan todos los registros de la violencia $[\ldots] .{ }^{111}$

A fin de cuentas, el cine "de ficheras" reitera la cosmovisión del sistema de deseo mediterráneo implantado en México, en el cual el "receptor" o pasivo durante el acto sexual es denostado, mientras que el activo es premiado por el aparato social. Cabe hacer esta aclaración por la presencia del "macho" apuntada por Muñoz: el sujeto masculino busca, a toda costa, lograr los "favores" de la mujer-prostituta, pero, esporádicamente, esta situación le permite cierto escamoteo homoerótico con el "maricón” de la cinta. El "macho", entonces,

111 Mario Muñoz, De amores marginales (Xalapa: Universidad Veracruzana, 1996), p. 12. 
no advierte un declive en su prestigio social, pues existe cierta permisividad en cuanto a su actividad sexual como "activo" se refiere.

Ahora bien, dejando a un lado la situación de las películas "de ficheras", el cine señalado por Schulz-Cruz como proveedor de una serie de imágenes homoeróticas, en las cuales se aborda la situación gay sin el cliché de la ridiculización, tiene en la década de los setenta una fervorosa eclosión. Entre las cintas más memorables puede citarse La isla de los hombre solos (1973), El lugar sin límites (1977) y, por supuesto, las películas de Jaime Humberto Hermosillo: El cumpleaños del perro (1974), Matinée (1976) y Las apariencias engañan (1977). En este caso, El lugar sin límites reviste una gran importancia, dado que se trata de una película reveladora no por colocar como protagonista a un personaje travestido, sino por articular todo un alegato en contra de la supuesta "naturalidad" de discurso hegemónico del género y la sexualidad. Este dispositivo quedó "al descubierto" en dicha cinta con la creación de un discurso homoerótico sometido sólo al designio del cuerpo y no a cuestiones sociales: si la corporalidad no permite una subordinación adecuada a los moldes de identidad propuestos y materializados en la misma ¿cómo es posible entonces advertir su existencia previa a la concepción del deseo? ${ }^{112}$

A finales de esta década plagada de movimientos y discursos artísticos en cuanto a la libertad sexual se refiere, aparece la emblemática novela El vampiro de la colonia Roma de Luis Zapata, publicada por la editorial Grijalbo en 1979. Hasta la fecha esta obra es, sin lugar a dudas, el texto narrativo de contenido homoerótico más popular de la literatura mexicana.

\footnotetext{
112 Para ampliar un poco más la información sobre esta película, sería bueno acotar lo mencionado por Schulz-Cruz: "El lugar sin límites es una obra de arte que va más allá de la presentación de una imagen homosexual. Es de hecho una metáfora de la condición humana y del discurso patriarcal en el que los personajes deben moverse. Para Ayala Blanco (La condición..., 382), El lugar sin límites es tal vez el film más antimachista en la historia del cine mexicano". Schulz-Cruz, p. 97.
} 
Esta aseveración la sustentan las diferentes reediciones de El vampiro... que han sumado más de treinta mil ejemplares vendidos. Pero más allá de la notoriedad del texto, hay una serie de aspectos que, en línea con la tradición literaria homoerótica inaugurada a plenitud en la década de los sesenta, ofrecen al lector un amplio y exquisito panorama de la concepción de la disidencia sexual en México.

El vampiro... es una novela transgresora en múltiples aspectos. Los dos más importantes están relacionados con su explícito contenido sexual homoerótico y el uso de recursos literarios poco convencionales para construir el discurso de la misma. Ambos elementos hacen del texto una apuesta por la ruptura y plantean la emergencia de identidades soterradas. El protagonista de El vampiro..., Adonis García, es un hermoso joven habitante de la Ciudad de México que, ante la falta de oportunidades de trabajo satisfactorias, opta por dedicarse a la prostitución con individuos de su mismo sexo. El lector se acerca a esta historia de una forma poco convencional: Adonis relata su vida a un autor ficcionalizado, quien, para retener los detalles de su interlocutor, usa una grabadora en la cual almacena la narración que, posteriormente, redacta en la forma de la novela en cuestión. Zapata ha confesado en varias entrevistas esta idea inicial; sin embargo, menciona también cómo dicho propósito fue aderezado, posteriormente, con elementos "ficcionales" que trastocaron completamente la versión inicial brindada por el joven informante. Otro rasgo peculiar de la novela es la ausencia de signos de puntuación: en un deseo por transmitir esta supuesta "fidelidad" del discurso del joven prostituto, la eliminación de estos signos produce en el lector un acercamiento mayor al plano oral. Así, en lugar de una coma o un punto hay espacios en blanco cuya finalidad es remitir a los suprasegmentos del largo monólogo del entrevistado.

Dividida en siete cintas - en un claro paralelismo entre los cassetes usados por el autor para salvaguardar la información obtenida y la posible capitulación del texto narrativo-, $E l$ 
vampiro... brinda un formidable y extenso panorama de la disidencia sexual existente, sobre todo, en la Ciudad de México. Además, aborda directamente -y sin escatimar en descripciones- el modo de asumir la homosexualidad por parte del protagonista, desde los primeros impulsos eróticos de la infancia y la adolescencia hasta la adultez. Este camino recorrido por Adonis funciona muy bien para ilustrar tres situaciones evidentes en la concepción del homoerotismo en el país: la salida del clóset -comming out-como modo de ruptura con el entorno y con las redes simbólicas de la sexualidad arraigadas en el individuo; el cambio de paradigma producido en las décadas de los sesenta y setenta en el dispositivo de género nacional; y las diversas identidades mantenidas al margen que surgen con genuina vivacidad en la novela, como los chichifos, las locas, los closeteros y demás variopintas denominaciones.

Sobre la primera situación, la salida del clóset, Adonis rememora la presión de un medio profundamente heterosexista que le exigía un comportamiento viril y un deseo orientado hacia la figura de la mujer. El protagonista advierte la lucha entre esta representación hegemónica y los deseos "prohibidos" al término de la niñez y, sobre todo, durante la adolescencia. En la primera cinta el protagonista narra a su interlocutor los cambios en su forma de masturbarse, cuya descripción alude al surgimiento del deseo homoerótico:

andaba caliente todo el tiempo y ya me masturbaba y tenía sueños mojados y todo pero fíjate qué curioso siempre me masturbaba pensando en chavos o bueno no al principio me acuerdo que me chaqueteaba viendo fotos de mujeres que venían en una revista que se llamaba "el pingüino" no sé si la conociste ¿sí la conociste? una revista argentina que traía unas viejas bien buenas je y también con otra que se llamaba "estrellas" "show de estrellas de cinelandia" y con los jajás mi hermano tenía un chorro de esa revistas tenía cantidad y entonces yo veía una vieja y siempre me imaginaba “y entonces yo veía una vieja y siempre me imaginaba que algún cuate estaba cogiendo con ella ¿no? 
me los imagina cogiendo a los dos ¿verdad? hasta que un día me empezó a interesar más la figura del chavo que estaba cogiéndose a la vieja y pensaba más en él o me concentraba más en él aunque no estuviera en la foto ¿ves? Y encontes así me venía yo creo que desde entonces mandé a las viejas a la verga o no más bien yo me mandé a la verga ¿verdad? sí pensaba a veces en picarlas pero pensaba que jugar con la verga del amigo era más interesante. ${ }^{113}$

Este fragmento distingue el inicio de un juego erótico marcado por una sexualidad normativa y el "desvío" de esta hacia el deseo intrínseco del Adonis. A partir de este momento, el protagonista construye su vida con base en las prerrogativas ofrecidas por su deseo, a las que agrega otra disyuntiva bastante fuerte con respecto al dispositivo de género imperante: la prostitución. De este modo, la novela de Zapata descubre la posibilidad de erigir una identidad abyecta con base en la felicidad de la misma sin la posibilidad de automarginación, en otras palabras, Adonis se instaura y observa su propia representación de género, sexual y laboral no como una instancia peyorativa, sino de modo placentero y, además, sin mortificación. Así, el hecho de prostituirse resulta para el protagonista un trabajo profundamente placentero, y esto es observado cabalmente cuando uno de sus clientes lo invita a su casa y le ofrece cobijo, alimento y vestido en ella durante el tiempo que Adonis lo quiera, siempre y cuando este corresponda sexual, amorosa y fielmente a su proveedor; no obstante, el protagonista, después de un par de semanas a prueba con él, rechaza absolutamente la propuesta y regresa a su flirteo y encuentros cotidianos con o sin necesidad de recibir un pago a cambio. Zapata hace, entonces, una apuesta provocadora y firme hacia la desestabilización del patriarcado y la heterosexualidad hegemónica en México, no sólo por la disidencia sexual del protagonista y las amplias descripciones eróticas, sino por la postura

\footnotetext{
${ }^{113}$ Luis Zapata, El vampiro de la colonia Roma (México: DeBolsillo, 2006), p. 20-21.
} 
reivindicadora de Adonis hacia su oficio, quien, en su trayecto como chichifo, realiza una amplia enumeración de los diversos sitios de ligue en el Distrito Federal. Esta situación enriquece aun más el texto, ya que abre las puertas del gueto y proporciona un posible mapa homoerótico de la urbe que, si ya antes era considerada por muchos un paraíso para la disidencia sexual, ahora es un auténtico espacio de apertura, el cual es reconocido y elogiado por el protagonista: “en esa época me parecía la ciudad de méxico la ciudad más cachonda del mundo la que más se prestaba a coger o a sea a que uno cogiera ¿verdad? la que más favorecía las este las relaciones sexuales entos y decía 'no ps si esta ciudad es cachondísma para muestra basta la torre latinoamericana que es el falo más grande de latinoamérica'". ${ }^{114}$ Aparte de este pasaje en el cual se elogia la magnificencia de la urbe como un sitio proveedor de encuentros eróticos, existen otros tantos en los que se rememora diversas calles y sitios del Distrito Federal donde pululaba una gran afluencia gay, entre los cuales destacan la esquina "mágica" de las avenidas Insurgentes y Baja California, la Zona Rosa y los Sanborns, entre otros. No cabe duda entonces de que la novela ofrece un horizonte bien definido de los espacios de flirteo y encuentro entre los integrantes de la comunidad homosexual citadina $\mathrm{y}$, de forma más escueta, relata cómo ocurren también estos acontecimientos en la provincia -sobre todo en Guanajuato y Acapulco, lugares donde vive y vacaciona, respectivamente, Adonis García.

Igualmente, el narrador de El vampiro... es pródigo en la descripción de sus encuentros homoeróticos y esta coyuntura permite acercar al lector a un "plano de normalidad" con respecto al erotismo gay. Dicho de otro modo, si en las décadas anteriores permeaba la consigna bien apuntada por Monsivaís sobre la lógica del ocultamiento -"lo que

114 Zapata, El vampiro de la colonia Roma, p. 159. 
no se nombre no existe, y lo nada más filtrado, y muy despreciativamente, en las conversaciones, es sórdido de suyo"115-, la novela de Zapata trastrueca este paradigma con la exhibición de la sexualidad exultante del protagonista. Este hecho corrobora lo dicho en páginas anteriores al respecto de reivindicar una identidad doblemente abyecta -el ser homosexual y prostituto- y sacude firmemente el dispositivo de género mexicano. Incluso, puede advertirse en ello una especie de prefiguración de lo que sería, algunos años más tarde, la teoría queer debido al cuestionamiento de la heteronormatividad y el uso del cuerpo sin los atavismos de las lecturas del género y el deseo hegemónicos.

En la misma década en la cual es publicada El vampiro de la colonia Roma aparece una novela emblemática para la literatura latinoamericana: El beso de la mujer araña (1976) de Manuel Puig. En este famoso texto hay un cuestionamiento enorme de la hegemonía con la cual se establece el dispositivo de la sexualidad de forma social y, a la vez, el modo en el cual ésta actúa psíquicamente dentro de los sujetos. Así, en los abundantes diálogos entre Molina y Valentín aparece filtrada esta información y la subversión de la misma con las respectivas traslaciones de los personajes. Sin lugar a dudas, El beso de la mujer araña constituye junto con El vampiro de la colonia Roma un paradigma en cuanto a un cuestionamiento sistémico del sistema patriarcal y la heteronormatividad se refiere, lo cual es la premisa básica de la posterior teoría queer. Con estos acontecimientos literarios, se tiene en Hispanoamérica un antecedente sólido y endémico del cuestionamiento del sistema de género, lo que provocó no sólo la "inclusión" del sujeto gay, sino el desmantelamiento de las redes simbólicas del poder implantadas con la linealidad insondable entre el sexo, el género y el deseo.

115 Monsiváis, Que se abra esa puerta, p. 51. 
Hasta este momento entonces -finales de la década de los sesenta- el camino recorrido por la liberación sexual en México y la paulatina "aceptación” del sujeto homosexual permea los discursos sociales mediante el activismo y las diferentes expresiones artísticas; no obstante, la década siguiente -los años ochenta- no serían nada fáciles para esta lucha y harían repensar el rumbo tomado. Al respecto, Salinas Hernández acota lo siguiente:

Para este momento [década de los ochenta], el MDS [movimiento por la diversidad sexual] se vio mermado por varios factores, entre los que destacan el cambio de modelo económico, la problemática económica que afecta a sus integrantes, la falta de definición de una estrategia política a mediano y largo plazo, fuertes diferencias internas entre los liderazgos y las organizaciones y, desde luego, la aparición del VIH/SIDA, que merma la membresía y la visibilidad alcanzadas por el movimiento. ${ }^{116}$

Sin duda, el sida afectó notablemente la visibilidad homosexual "ganada" durante el decenio anterior. Para Monsiváis, esta situación permitió un resurgimiento -si es que en algún momento había disminuido- de la homofobia social en buena parte del orbe. Incluso, llegó y a veces aun prevalece- a considerarse al sujeto gay como una persona enferma y, por tanto, de alta peligrosidad para el entorno social.: "la visibilidad del sida, desde sus inicios se homosexualizó. Todo cuerpo con sida pasó a ser un cuerpo homosexual, o, en todo caso, un cuerpo desalmado." ${ }^{117}$ Esta coartada permitió entonces, desde los aparatos del poder y las normas religiosas imperantes en el país, realizar un binomio perfecto fundamentado en la crítica hacia la disidencia sexual y la relación de ésta con el virus. ${ }^{118}$ Incluso, tanto en México

\footnotetext{
116 Héctor Miguel Salinas Hernández, Políticas de disidencia sexual en América Latina, pp. 83-84.

117 Javier Sáenz, "El contexto sociopolítico de surgimiento de la teoría queer: de la crisis del sida a Foucault", en Teoría queer, p. 68.

${ }^{118}$ En "De las variedades de la experiencia homoerótica", Monsiváis hace una adecuada síntesis de este hecho: "Ya en 1985 se transparentan en México las dimensiones de la pandemia del sida, precedida del alarmismo y los terrores a propósito del 'cáncer rosa'.[...] La demonización no conoce tregua: 'no coma cerca de un homosexual. Puede contagiarse', reza un anuncio pegado por las calles. El nuncio papal
} 
como en otras latitudes, el propio movimiento por la diversidad sexual comenzó a cerrar filas al respecto, manifestando lo que sería conocido más tarde como "la traición gay". ${ }^{119} \mathrm{La}$ pandemia generó también un cambio en cuanto a "sus prioridades y demandas de tipo reivindicativo a demandas relacionadas con la salud pública." ${ }^{120}$ Varios grupos libertarios cambiaron sus ámbitos de trabajo tradicionales por la exigencia de la implementación de una red sanitaria eficiente encaminada no a una satanización de la enfermedad, sino a la búsqueda de acciones para su control y el apoyo necesario para las personas contagiadas.

Pero no todo fue catástrofe y crisis durante estos años. Al contrario, de forma paradójica, el SIDA trajo consigo -aparte del nacimiento de una homofobia más recalcitranteuna nueva forma de pensar la disidencia sexual y, además, un cuestionamiento severo y profundo de los principios que sostenían la sexualidad hegemónica. Produjo, de modo paulatino, cambios en las leyes del país y los sistemas de salud, a lo que se puede agregar una reorganización del movimiento por la diversidad sexual.

La tragedia, por tanto, no sólo fue en el espacio físico sino también en el intelectual. Estas dos actitudes recalcitrantes, tanto por el aparato de poder como por los grupos

Girolamo Prigione califica al sida de 'castigo de dios', en varias empresas se hacen pruebas obligatorias de detección del sida, y a los que se les encuentra la seropositividad se les conmina a salir en ese momento y, definitivamente, de la empresa. En los gobiernos de Miguel de la Madrid, Carlos Salinas de Gortari y Ernesto Zedillo, la Secretaría de Salud no lanza campañas dirigidas específicamente a los gays, porque, es de suponerse, el Estado no puede ni debe reconocer la existencia de enfermedades derivadas de perversiones.[...] A la irracionalidad de los crímenes de odio contra los homosexuales se añade el pánico desatado por el sida". Monsiváis, pp. 164-165.

119 Javier Sáenz menciona, en el mismo artículo aquí citado, cómo a finales de los setenta y principios de los ochenta ocurre una crisis en el interior del movimiento gay. Este hecho, según Sáenz, tiene su origen en una especie de "cuotas de normalidad", es decir, que, para lograr una mayor aceptación por parte de la sociedad heteronormada, muchos grupos en pro de la disidencia sexual sugieren un acatamiento de los parámetros del sistema de género hegemónico. Sin duda, entre estos parámetros se halla el matrimonio y un anhelo exorbitado por igualar a los heterosexuales en su forma de vida; por tanto, todos aquellos sujetos cuyos deseos y representación no se acercaban a este suceso fueron rechazados por la misma disidencia. A esta crisis se suma entonces la provocada por la contingencia del sida, cuya presencia vino a agravar aún más el rechazo y automarginación.

120 Salinas Hernández, p. 84. 
liberadores, generaron una suerte de pérdida de brújula. Se creó un problema severo con respecto a la identidad gay que marcó un cerco hegemónico: aquellas identidades consideradas como "más marginales" fueron excluidas, entre ellas la de los contagiados por el VIH. En el panorama internacional el desarrollo histórico fue muy similar: el rechazo generalizado generó un terrible sacudimiento en el movimiento de liberación gay que condujo a la fractura en diversos países. Este contexto, aunado a los trabajos teóricos de autores como Monique Wittig y Michel Foucault provocó el surgimiento de uno de los debates académicos más polémicos de las últimas décadas: la teoría queer.

En México, los efectos convocados por la famosa "crisis del sida" pusieron de manifiesto el hermetismo absoluto del poder sobre el hecho y la formación de varias organizaciones ciudadanas al respecto. Además, en línea con la situación internacional, comenzó a darse un replanteamiento de los modos de promover la ruptura de la marginación de los disidentes sexuales, que cristalizó en el surgimiento de una aguda crítica de la forma de concebir las diversas normatividades sobre el cuerpo en la sociedad mexicana.

Por otro lado, en el plano artístico, la década de los ochenta fue muy fructífera en cuanto a cine y literatura de tema homosexual se refiere $-\mathrm{y}$, prueba de ello, son los cuentos publicados durante este lapso cuyo análisis aparecerá en capítulos posteriores de este trabajo. Un filme muy emblemático para la comunidad gay mexicana fue Doña Herlinda y su hijo (1984) del ya mencionado Jaime Humberto Hermosillo. En dicho filme, cuya base por supuesto es el cuento homónimo de Jorge López Páez, se da la presencia de lo homoerótico de forma muy clara y sin mayores preámbulos. Sin duda, es una de las películas más paradigmáticas al respecto de la exhibición de la disidencia sexual en el cine y no hay duda de que su influencia ha sido muy amplia, sobre todo en cuanto a la libertad de la evidencia de dichos personajes se refiere. Al respecto Schulz-Cruz menciona: "Este film puso la 
homosexualidad en el centro de la familia mexicana, ya no era el burdel ni el ambiente sórdido. El espectáculo gay por fin tuvo un apoyo simbólico en la gran pantalla. [...] Las imágenes no sucumben a la historia del silencio o del amarillismo. Sin lugar a dudas esta película reivindica la homosexualidad, el amor y la pareja gay; en suma, la tolerancia sin escándalos ni dramas". ${ }^{121}$ El mismo autor señala otras tantas cintas pertenecientes a la década de los ochenta en las cuelas el tema homoerótico se hace patente, como El otro(1984), ¿Cómo ves? (1985), Casos de alarma 1/SIDA (1986), entre varias más. De este modo, estos años se vuelven fructíferos en cuanto a la visibilidad del sujeto gay en la pantalla grande se refiere.

Ahora bien, en el ámbito literario, esta década también fue muy abundante. Uno de los autores más prolíficos fue Luis Zapata, quien publicó Melodrama (1983), En jirones (1985) y La hermana secreta de Angélica María (1989). Estas tres novelas son un auténtico panorama de la disidencia sexual que abarca desde la clásica "salida del clóset", hasta el tema escabroso representado por el hermafrodita, ${ }^{122} \sin$ olvidar los diferentes problemas inscritos en las relaciones de pareja homosexuales.

Resulta oportuno mencionar otro hecho muy significativo ocurrido en la década mencionada: el papel de la música popular en la formación de una identidad soterrada. Al igual que lo ocurrido con décadas anteriores en las cuales el bolero o la música disco habían

\footnotetext{
121 Schulz-Cruz, p. 110.

122 Cabe destacar que este texto es muy original e innovador en cuanto al tema se refiere. Hasta esa fecha la literatura mexicana pocas veces había reparada en la figura del hermafrodita; si bien a lo largo del siglo XIX y durante la primera parte del XX hubo varios acercamientos a la figura del travesti, como más adelante se verá en los cuentos estudiados, el hermafrodita era un tema muy eludido. Innegablemente, esta circunstancia está atravesada por los vericuetos de dicha representación en la sociedad mexicana: el terror producido por un ser que aglutine las características de ambos "sexos" pone en entredicho numerosos axiomas naturalizantes del género y la sexualidad. Por otro lado, Zapata también plantea los problemas que dicha representación, así como las ataduras de género con respecto al deseo erótico en el ámbito femenino, producen en un personaje, al grado de formular en el mismo un sentido de marginalidad y destrucción. Resulta un poco paradójico que la crítica no haya reparado demasiado al respecto de este texto, a no ser por el estudio de Óscar Eduardo Rodríguez sobre la obra de Zapata en general.
} 
creado un lenguaje musical, corporal y, podría decirse también, literario que desembocó en una "identificación" y aglutinación masiva de la "disidencia sexual”. En los ochenta sucedió un hecho parecido: la comunidad gay inició una suerte de adquisición o resignificación de un corpus abundante de canciones, interpretadas en su mayoría por mujeres. ${ }^{123}$ Dulce, Rocío Jurado, María Conchita Alonso, Lupita D’Alessio, Yuri, Ángela Carrasco, Marisela, Amanda Miguel, Crystal, Prisma, Paloma San Basilio, Rocío Dúrcal, Isabel Pantoja, Lucha Villa entre otras más, ingresaron de lleno a la predilección de toda una comunidad que, probablemente, concebía en el hecho del dolor producido por el varón en la idealización femenina del amor la misma insatisfacción/dicha por la ausencia/presencia del sujeto amado; Ortiz y Rivera ven en este proceso de identificación un modo mediante el cual "algunas de las intérpretes [...] definieron en sus canciones diferentes formas de amar que muchos hombres adoptaron y dedicaron a otros hombres". ${ }^{124}$ Es preciso decir también que dichas canciones siguen siendo escuchadas, y no sólo por las personas a quienes les correspondió vivir dicha época, sino también por otros sujetos más jóvenes cuya identificación con las mismas es innegable.

En continuidad con este recorrido sobre las concepciones del homoerotismo en México debe acotarse que, hacia la década de los noventa, como ya se mencionó páginas atrás, cobró un énfasis rotundo todo lo relacionado con las cuestiones queer en México. La pandemia provocada por el SIDA siguió dejando numerosas víctimas y cambiando el modo de pensar de la sociedad mexicana. Por otro lado, la visibilidad del "ambiente homosexual" se hizo mucho más efusiva a través de los grandes y luminosos desfiles de la comunidad: "En

\footnotetext{
${ }^{123}$ Esta circunstancia no pertenece únicamente a México, en todo el mundo hispánico ocurrió algo similar. Al respecto de esto en Colombia puede verse la novela Al diablo con la maldita primavera (2002) de Alonso Sánchez Baute, en la cual la protagonista posee todo un repertorio de canciones e intérpretes con la capacidad de aglutinar ciertas fibras sensibles de las identidades "disidentes".

${ }^{124}$ Tareke Ortiz y Nayar Rivera, "El éxtasis a una identidad del deseo. La música como experiencia de libertad”, en México se escribe con J, pp.190.
} 
México a la Marcha del Orgullo en la capital [...], se agregan desde fines de la década de 1990 las de Monterrey, Guadalajara, Oaxaca, Puebla, Aguascalientes, Tijuana. Calificadas al principio de "impudicia" o de "afrenta pintoresca", las marchas atestiguan las libertades en la ciudad". ${ }^{125}$ Igualmente, las instituciones del Estado, a costa del notable impulso dado por la propia sociedad civil, comenzaron a tomar en cuenta los efectos del VIH a partir de campañas de salud encaminadas a la prevención y tratamiento de la enfermedad. Es de notar entonces cómo, con respecto a las décadas de los setenta y los ochenta, la de los noventa viene a ser casi una síntesis de las dos anteriores: el movimiento por la "disidencia sexual" cobra brío y, a la par, se da un replanteamiento de los mecanismos de acción y el tomar en cuenta a las víctimas de la pandemia tanto desde los sectores estatales como desde el movimiento liberatorio. Obviamente, con esto no se pretende decir que se dio un giro total de la noche a la mañana, sino que se observa cómo el camino tomó un nuevo rumbo, cuyos efectos continúan a la fecha e, igualmente, hay un vasto territorio por defender y rearticular.

La década de los ochenta, de modo muy similar a su contraparte anterior, cimenta las bases de una nueva forma de advertir la disidencia sexual a partir de modelos de visión que poco o nada tienen que ver ya con una homonormatividad. Además, esta década es particularmente fructífera en cuanto al surgimiento del cuento mexicano de tema homoerótico, como se verá más adelante en el capítulo "Consolidación (1961-1990)" del presente trabajo. Así, este decenio marca un giro profundo en la concepción de la sexualidad que tendrá su auge hacia los siguientes años. En consecuencia, la década de los noventa inicia fuertemente afecta todavía por la cosmovisión creada ante la pandemia del SIDA: la sociedad mexicana tiene aún temor ante los imaginarios embates de la enfermedad, dado que crea toda

\footnotetext{
${ }^{125}$ Monsiváis, p. 159.
} 
una suerte de formas de contagio inexistentes y postula que, únicamente los disidentes sexuales, era capaces de contraerla. A diferencia de los Estados Unidos, que ya posee una perspectiva muy diferente sobre esta cuestión de salud pública, en México aún existe, hacia inicios de los noventa, una preeminencia del rechazo, la ignorancia, la segregación y discriminación, entre otros tantos factores que intervinieron en el forjamiento de una identidad, más abyecta que la homosexualidad, con base en la existencia del virus.

Ahora bien, en cuanto a la consolidación de un aparato teórico que abordara la perspectiva de la identidad y su relación con una determinada sociedad, es hasta estos años cuando comienza, en el país, la llegada y surgimiento de ideas muy cercanas a la teoría queer. Esta situación pude observarse también en el acontecimiento literario, especialmente en el cuento. En El personaje gay en seis cuentos mexicanos (2011), el autor de la presente investigación realizó un análisis de los textos "El alimento del artista" de Enrique Serna y "Bernal y Beatriz" de José Joaquín Blanco. En ambos relatos hay una apuesta directa sobre el tema de la identidad como un hecho construido socialmente y, a la vez, cuestionan la base de esta edificación. Los personajes creados por Serna y por Blanco deambulan en espacios geográficos bien delimitados, en los cuales la presencia de lo "mexicano" es relevante, para conformar una diatriba contra lo hegemónico, especialmente el patriarcado y la heterosexualidad normativa. Esta cercanía con lo queer no es gratuita, y obedece en buena medida a las cuestiones de la posmodernidad, que empieza tener numerosos acercamientos con base en el hecho literario. Como es sabido, este giro fue documentado por Francois Lyotarde en La cuestión posmoderna, y ha tenido un eco importantísimo en los estudios literarios; sin embargo, para no extender más el presente aparado, no se redundará demasiado al respecto del tópico. No obstante, es posible señalar cómo el cruce entre la posmodernidad y la teoría queer ha creado una nueva perspectiva, un nuevo asidero desde el cual se puede 
partir para observar la realidad y deconstruirla. Queda claro que este hecho no permea toda la literatura mexicana de la época ni los estudios críticos elaborados sobre la misma; sin embargo, para el tema que aquí compete es necesario tomarla en cuenta con el fin de advertir los vericuetos en los cuales se está movimiento la identidad disidente en estos años.

Por otro lado, el capítulo final de este trabajo "Cuestionamiento (1991-2014)", si bien sólo posee dos cuentos para ilustrar el hecho, hace una síntesis de los principales presupuestos de estas teorías con el fin de entremezclarlas con el análisis de los relatos ahí estudiados “Amor propio” de Enrique Serna y “¿Te gusta el látex, cielo?” de Nadia Villafuerte. Lo que principalmente se obtiene de este acercamiento es la vitalidad cobrada por el giro queer a partir de la década de los noventa. De este modo, la sociedad mexicana inicia un camino de transformación rotunda y se producen numerosos cambios que han sacudido la moral imperante, entre ellos, uno de los más recalcitrantes ha sido el matrimonio homosexual y la adopción por parte de parejas homoparentales. Aunque esto último no se ha dado por completo en todo el país, la legalidad de la unión es vigente y, en teoría, debe ser respetada en todos los espacios geográficos de México. Por otro lado, mucha gente se ha sumado a creer que el matrimonio homosexual lejos de favorecer la causa de la "liberación sexual" se ha convertido en un lastre. Esta hipótesis tiene su antecedente en la misma teoría queer, la cual punga por un levantamiento en contra de las hegemonías, y el matrimonio, en este caso, es considerado como algo hegemónico que es emulado por parte de la comunidad homosexual. Desde la mirada queer, todo aquello que represente una copia de la heterosexualidad debe ser eliminado y lo que se propone entonces en la reelaboración de los valores sobre los cuales está cimentada la sociedad del país.

Así, durante las últimas dos décadas el énfasis que se ha puesto en la desarticulación del aparato de poder inscrito detrás de la sexualidad crea una forma absolutamente diferente 
de concebir el cuerpo. En estos años, el debate entre los construccionistas y los esencialistas ha adquirido un fuerte arraigo, aunque, sin duda, la balanza queda inclinada más hacia los primeros. Por lo tanto, el cuerpo es considerado como un espacio de pugna en el que se entrecruzan situaciones políticas para convertir al individuo en un "sujeto", socialmente hablando. 
Estudios sobre literatura mexicana de contenido homoerótico

El objetivo primigenio de este apartado es hacer un estado de la cuestión acerca de la crítica literaria realizada en torno del cuento mexicano de tema homoerótico. De este modo, los estudios que anteceden a este trabajo pueden ser clasificados en dos grupos: 1) los diversos acercamientos a la literatura gay del país y 2) los trabajos de investigación hechos específicamente sobre el homoerotismo dentro de la cuentística mexicana.

Por otro lado, se encuentran los estudios dedicados a la investigación y organización del este género narrativo desde la época prehispánica hasta la actualidad. Estos trabajos son un gran punto de partida para anclar crítica y temporalmente los cuentos seleccionados para la presente investigación. Se hallan en este inciso los estudios de Luis Leal -Breve historia del cuento mexicano (1956), Bibliografía del cuento mexicano (1958) e Historia del cuento hispanoamericano (1971)-, Emanuel Carballo -Bibliografía del cuento mexicano del siglo XX (1988)-, Russel M. Cluff -Panorama crítico-bibliográfico del cuento mexicano (19501995) (1997) y Los resortes de la sorpresa (Ensayos sobre el cuento mexicano del siglo XX) (2003)-, Alfredo Pavón -Cuento de segunda mano (1998), Al final, recuento (2004) y los volúmenes coordinados y editados por el autor sobre la ficción breve publicados por la Universidad Autónoma de Tlaxcala- y Lauro Zavala -Paseos por el cuento mexicano contemporáneo (2004). El objetivo de citar estos estudios dentro del estado de la cuestión radica en que dichos trabajos tienen la función de contextualizar plenamente el itinerario cuentístico del país. Han fungido como punta de lanza para promover el acercamiento al cuento mexicano y generar líneas de investigaciones temáticas e históricas. 
Ahora bien, entre los acercamientos realizados a la literatura gay mexicana destacan los siguientes: La novela mexicana entre el petróleo, la homosexualidad y la política (1997) de Luis Mario Schneider; Gay and Lesbian Themes in Latin American Writing (1991), Producción cultural e identidades homoeróticas (2000) y Ensayos sobre culturas homoeróticas latinoamericanas (2009) de David William Foster; Salvador Novo, lo marginal en el centro (2000) y Que se abra esa puerta (2010) de Carlos Monsiváis; ;Que se quede el infinito sin estrellas! (2001) y El crepúsculo de Heterolandia (2006) de Antonio Marquet; y México se escribe con J (2010), de Michael K. Schuessler y Miguel Capistrán. En este apartado se incluyen también algunos artículos de la Revista Iberoamericana en su número 225, correspondiente a octubre-diciembre de 2008, titulado Los estudios lésbico-gays y queer latinoamericanos; los acercamientos hechos por Rodrigo Laguarda a la novela y vida gay mexicanas; y algunos ensayos incluidos en El deseo, enorme cicatriz luminosa: Ensayos sobre homosexualidades latinoamericanas (2004) y de Sexualidades en disputa. Homosexualidades, literatura y medios de comunicación en América Latina (2005) de Daniel Balderston. La mayor parte de estos trabajos oscila entre el estudio de la literatura y la cultura homoerótica. A su vez, tratan de dar un panorama general sobre la vida gay mexicana, en particular, y latinoamericana, en general como es el caso de Foster y Balderston. En cambio, Monsiváis, Marquet y el compendio de México se escribe con $J$ están focalizados, en su totalidad, sobre la vivencia homosexual en los ámbitos culturales, sociales y literarios del país. A través de estos estudios se ha podido concretar un corpus literario gay mexicano que puntualiza su atención sobre el género de la novela y la poesía.

Sobre el último inciso, dedicado únicamente a la investigación del homoerotismo en el cuento gay mexicano, las referencias son mucho menores. Dentro de los ya señalados en el apartado anterior, cabe citar los trabajos de Marquet, en los que el autor desarrolla una 
crítica hacia los modos de representación de la vida gay mexicana en el cuento. Los narradores citados por Marquet pertenecen a la literatura de la segunda mitad del siglo pasado, como Inés Arredondo, Eduardo Antonio Parra, Enrique Serna y Luis Zapata, por citar sólo algunos. En ;Que se quede el infinito sin estrellas!, el investigador incluye un trabajo de crítica sobre la antología de cuento De amores marginales (1996) elaborada por Mario Muñoz. Esta compilación es pionera en el ámbito del cuento gay mexicano por tratarse del único trabajo antologador sobre el tema. En ella hay un recorrido por las diversas manifestaciones de la homosexualidad: el personaje travestido, el sujeto "disidente" enfrentado con su entorno y familia, la formación de la pareja gay, el auto-escarnio creado por una homofobia internalizada, el goce pleno de la sexualidad y el problema del encasillamiento con base en las identidades genéricas, entre otros.

Ahora bien, sobre las indagaciones realizadas en torno del homoerotismo en la literatura mexicana no se puede dejar a un lado el trabajo pionero, ya citado en esta investigación, de Luis Mario Schneider titulado La novela mexicana entre el petróleo, la homosexualidad y la política. En dicho texto, Schneider brinda al lector un iluminador recorrido histórico por la novela mexicana de tema homoerótico. El autor inicia con una breve semblanza de la construcción de la "homosexualidad" en México, y para lograr dicho cometido acude al tema de la fiesta de los 41 en el México porfirista. Con este punto de partida, el autor introduce el tema de lo público y lo privado, y llega a la conclusión de que en el primer ámbito se esconde, mediante la forma de la máscara, una clara alusión a la "disidencia sexual" como contraparte de la heterosexualidad reinante. Posteriormente, hace un puente entre lo que sería la citada fiesta y las características "actuales" de la liberación sexual. Hace una analogía con el tema de lo literario y aduce que "la literatura homosexual en México tiene tradición, aunque su estudio y su investigación comienza en época reciente 
y en cierta forma coincidente con la aparición, diría con la explosión, en estos últimos años, de un buen número de obras sobre el tema. Con plena conciencia de decir una perogrullada, es demostrable que la creación estética individual está sujeta a condiciones de presión social". ${ }^{126}$ Y, precisamente, Schneider es uno de los pioneros en el estudio de la literatura mexicana de contenido homoerótico, ${ }^{127}$ que si bien en las últimas décadas ha crecido en cuanto a la proliferación de creadores que abordan el tópico, tampoco es un tema reciente. No obstante, Schneider aborda poco dicho tópico en la literatura anterior a la década de los sesenta e inicia precisamente en estos años su recorrido: "La primera novela de tema homosexual, en México, la escribió Miguel Barbachano Ponce, a finales de 1962. El diario de José Toledo apareció en 1964 en edición del autor". ${ }^{128}$ Posteriormente, el trabajo del investigador consiste en establecer un copioso breviario de autores y obras, de las cuales establece una breve síntesis, su cercanía con la tradición de la literatura de índole

\footnotetext{
${ }^{126}$ Luis Mario Schneider, La novela mexicana entre el petróleo, la homosexualidady la política (México: Nueva Imagen, 1997), p. 70

${ }^{127}$ Como bien el título lo señala, el autor se dedica solamente a hacer un repaso por el género de la novela; sin embargo, anota brevemente algunos textos para poner el tema sobre la mesa y, claro está, propiciar la investigación al respecto: "No estudiaré los valiosos ensayos creativos de Las locas, el sexo y los burdeles de Salvador Novo o Las antiguas historias de amor de Francisco de la Maza; el propio Diario de Novo publicado en dos números de Nuestro cuerpo, órgano del Frente Homosexual de Acción Revolucionaria, ni la obra de teatro e Hugo Argüelles, El ritual de la salamandra, o el anecdotario de Sergio Fernández, Los desfiguros de mi corazón. Tampoco hablaré de cuentos que recogen el tema aisladamente, pero cuyos nombres menciono: El vino de los bravos de Luis González de Alba, Los magos de A. López Chavira, Opus 123 de Inés Arredondo, o las narraciones de Gonzalo Martré, de Fidencio González, José Ceballos Maldonado, Alberto Dallal, Luis Arturo Ramos, Agustín Monsreal, Raúl Hernández, etcétera. Paso también por alto el análisis de situaciones y personajes que se dan en las novelas de José Revueltas, Luis Spota, Emilio Carballido, Vicente Leñero, Jorge López Páez, Juan Vicente Melo, o en obras más recientes como Los hombres dulces de José Antonio Nava Tagle. Dos últimos abandonos: no hablaré tampoco de la poesía, ni siquiera de esa larga leyenda en verso y de fantasmas que es El ánima de Sayula, leída y criticada en el siglo pasado. También solamente me referiré a la literatura homosexual de tema masculino, que es, en comparación con la femenina, la más fructífera. Entonces suprimo, por ejemplo, la visión de Figura de paja de Juan García Ponce, Los sueños de Violeta de Armando Sarignana, y la reciente obra de Eugenio Aguirre, En el campo". Schneider, La novela mexicana entre el petróleo, la homosexualidad y la política, pp. 71-72.

${ }^{128}$ Idem, p. 73.
} 
homoerótico y, también, el diálogo establecido entre las diégesis de los textos acotados y la situación social del país con respecto a la "disidencia sexual".

La lista de novelas que presenta Schneider está integrada por los siguientes títulos: 41 o el muchacho que soñaba con fantasmas (1964) de Paolo Po, Los inestables (1968) de Alberto X. Teurel, Después de todo (1969) de José Ceballos Maldonado, Cielo tormentoso (1972) de Carlos Valdemar, La máscara de cristal (1973) de Genaro Solís, ${ }^{129}$ Mocambo (1976) de Alberto Dallal, El desconocido (1977) y Flash back (1982) de Raúl Rodríguez Cetina, Hasta en las mejores familias (1975), El vampiro de la colonia Roma (1979) y Melodrama (1983) de Luis Zapata, Omicrón (1980) de Luis Eduardo Feher, Octavio (1982) de Jorge Arturo Ojeda, Sobre esta piedra (1982) de Carlos Eduardo Turón, Las púberes canéforas (1983) de José Joaquín Blanco, Utopía gay (1983) de José Rafel Calva y, la más reciente para la fecha de publicación del texto del investigador, Letargo de Bahía (1992) de Alberto Castillo. Para concluir, y después de haber realizado una breve síntesis de cada uno de los textos aquí anotados, Schneider acota lo siguiente que resulta bastante ilustrativo al respecto del estado guardado por el tema homoerótico en la literatura mexicana:

Este resumen me exige una sola y final reflexión. Veinte años hay entre el suicidio del adolescente de El diario de José Toledo, de Miguel Barbachano Ponce, y el hijo que va a nacer de Utopía gay, de José

\footnotetext{
${ }^{129}$ Schneider menciona que varios de los autores convocados en su repaso por la novela mexicana de corte homoerótico han publicado estos textos con base en pseudónimos, entre los cuales se encuentran Paolo Po, Alberto X. Teurel, Carlos Valdemar y Genaro Solís. Por obvias razones, este motivo funciona a modo de advertir también una posible sanción social en el proceso de recepción del texto, lo cual permite imaginar cómo la participación del lector podría "condenar" al autor en curso. Igualmente, el crítico acota cómo en la novela Máscara de cristal existe un epígrafe que dicta: "Exclusivo para personas de muy amplio criterio". Habría que repensar ahora cómo, a lo largo de varias décadas de manifestación y desestabilización de la hegemonía patriarcal y heterosexual, la literatura gay ha pasado de un lugar casi periférico a uno central. Además, todo esto sería en un ámbito de estudio o exhibición, porque, como bien anota Gregory Woods en su ya citada Historia de la literatura gay, este tipo de escritura ha estado, de modo subrepticio, dentro del propio canon. En el caso de México, el ejemplo estaría en la portentosa presencia de los Contemporáneos, quienes moldearon fecundamente el corpus de la poesía mexicana.
} 
Rafael Calva. Veinte años de la tragedia a la comedia, y cuando una cultura comienza a sonreír a través de la estética es el mejor índice de que ya ha comenzado la lucha verdaderamente crítica, que escasamente tiene que ver con el rechazo, con el sufrimiento o con la conformista lamentación. ${ }^{130}$

Al respecto, Carlos Monsiváis realizó un extenso trabajo de indagación y crítica sobre la literatura mexicana de tema homoerótico. En una intersección con los estudios culturales, Monsiváis aprovecha la coyuntura para enlazar una tradición homoerótica literaria con las diferentes representaciones de la homosexualidad en el país. Esto se aprecia con gran claridad en los artículos que publicó durante más de veinte años -desde 1990 hasta pocos meses antes de su muerte- en la revista Debate Feminista. En las páginas de esta publicación imprescindible dentro de los estudios sobre el género y la disidencia sexual en México, Monsiváis hizo numerosas y valiosísimas apologías sobre la homosexualidad en la literatura del país. Los ensayos en los que aborda más directamente este acontecimiento son “'Los que tenemos unas manos que no nos pertenecen' (a propósito de lo queer y lo rarito)" (1997), "Los iguales, los semejantes, los (hasta hace un minuto) perfectos desconocidos (a cien años de la redada de los 41)" (2001), y "De la marginalidad sexual en América Latina 'Hay días en que somos tan lúbricos, tan lúbricos"” (2009). Estos textos, junto con otros del mismo autor que también se dieron cita en Debate Feminista, fueron publicados recientemente -en 2010- bajo el título Que se abra esa puerta. Crónicas y ensayos sobre la diversidad sexual.

En el primer artículo señalado, "Los que tenemos unas manos que no nos pertenecen...", Monsiváis hace una breve historia del acontecimiento homoerótico en la cultura y literatura del país. Con base en una aguda suspicacia, el cronista señala autores y textos en cuyas páginas se ha hablado -ya sea en favor o en contra- de la homosexualidad.

\footnotetext{
${ }^{130}$ Schneider, pp. 87-88.
} 
Principalmente, dedica este trabajo a la indagación del aporte de los Contemporáneos, como pilotos de la nave de visibilidad de la disidencia, y busca, a la vez, algunos indicios del homoerotismo en la literatura decimonónica

En el segundo artículo, "Los iguales, los semejantes...", el autor analiza la estrategia del patriarcado y la heteronormatividad mexicana -que denomina como "la lógica del ocultamiento"- en la novela de José Tomás de Cuéllar titulada Historia de Chucho "el Ninfo" (1871). Para Monsiváis, en dicho texto hay una clarísima "descripción del gay", pero, por razones inmanentes a la moral decimonónica, no se nombra de forma directa el "pecado nefando" en atención a la sensibilidad de los lectores. Después, continúa con la visión de la homosexualidad tenida durante el porfiriato y, además, analiza los versos de Arsacio Vanegas Arroyo que acompañaron los grabados de José Guadalupe Posada, en cuyas líneas aparece la evidente cultura homofóbica de la época. En esta misma línea de desprecio hacia el "disidente sexual", está la ya mencionada novela de Eduardo A. Castrejón, Los cuarenta y uno, de quien Monsiváis acota la contradictoria curiosidad del autor por tan "abyecto" suceso. Posteriormente, se detiene en la novela de Francisco Rojas González, La negra Angustias. Con base en este relato, Monsiváis hace un señalamiento al cuerpo "transexual" de la Revolución Mexicana representado por la masculinización de la mujer cuando debe entrar al movimiento armado.

Por último, en "De la marginalidad sexual en América Latina...", el cronista articula un acercamiento a la literatura latinoamericana a partir de la disidencia sexual. En este artículo, Monsiváis cita a Porfirio Barba-Jacob, Luis Cernuda, Emilio Ballagas, Salvador Novo, Xavier Villaurrutia, Carlos Pellicer, Raúl Gómez Jattin, Pedro Lemebel, Reinaldo Arenas, Néstor Perlongher y Carlos Montenegro, entre otros. A partir de estos autores, hay un análisis de una poética de la diáspora y la resistencia contra un deliberado aparato de poder 
que constriñe al cuerpo. No obstante, este acercamiento está pertinentemente mezclado con las representaciones de la linealidad entre el sexo, el género y el deseo provistas por la cultura latinoamericana: todos los países que la conforman, herederos de una común tradición judeocristiana, apelan a un arquetipo de masculinidad y feminidad, cuyas directrices son rotas por los escritores aquí citados.

Antonio Marquet ha sido otro gran investigador estudioso de la disidencia sexual en la cultura y la literatura mexicanas. En dos grandes volúmenes, -iQue se quede el infinito sin estrellas! y El crepúsculo de Heterolandia- donde reúne numerosos artículos al respecto, explora la concepción del homoerotismo en el teatro, la música, el cine, la plástica y la literatura. Sobre esta última, sus estudios han abarcado desde la presencia de los Contemporáneos hasta las últimas representaciones de la disidencia sexual. Con este recorrido, el autor realiza una caracterización de la homosexualidad en México y, a la vez, apela por una deconstrucción de los discursos opresores: el patriarcado y la heteronormatividad. En ;Que se quede el infinito sin estrellas!, además, hace una acertada definición de la obra artística gay:

Desde mi punto de vista son gay aquellas obras concebidas por homosexuales y que retratan o evocan la forma de vida gay. También deben considerarse dentro de la cultura gay aquellas producciones cuya temática no aborda directamente la vida homosexual, pero son obra de artistas gay. Asimismo debe incorporarse aquellas producciones de heterosexuales o bisexuales e incluso de homófobos, que se integran como referencias obligadas de la comunidad homosexual. De igual manera que una telenovela dirigida a la "gran familia mexicana", escrita por un guionista gay; un relato escrito por un gay con protagonistas heterosexuales, sin referencia alguna a la vida gay u homosexual, deben ser incluidos dentro de la cultura gay. De la misma manera que obras escritas por heterosexuales con alusiones, caracteres, o con temática homosexual, pertenecen a la cultura gay, como algunos cuentos de Inés 
Arredondo, por ejemplo. Un concepto amplio de cultura gay se levanta en contra de una visión marginalizante que pretende considerar como "rara" a la vida homosexual. ${ }^{131}$

Unas líneas más adelante, realiza ya una entrada en los términos de la teoría queer, pero desde la perspectiva aún de la disidencia gay, para extender el concepto de obra artística gay a un cuestionamiento generalizado de las normatividades sexuales: "El concepto de cultura gay va más allá de la pulverización de la diferencia sexual que introduce categorías en cascada [...] de hecho es toda aquella manifestación que van en contra del empobrecimiento cultural que pretende reducir todo a una bipolaridad masculino-femenino; todo aquello que se declara en contra de distinciones tajantes y grotescas en el terreno de la sexualidad". ${ }^{132}$ Esta postura bien puede ser tomada como punto de partida teórico para cualquier estudio que intente dilucidar las barreras epistemológicas y discursivas entre una supuesta "heterosexualidad" u "homosexualidad" en la literatura.

Dentro del volumen citado, Marquet recoge algunos artículos que tienen como eje de análisis el homoerotismo en la literatura mexicana. Entre ellos están “La estatua de Sal-vador Novo y las chicas de Donceles", "Elías Nandido: 'Más allá del polvo", "Ceballos Maldonado: poética de la impureza”, "Puig y la morbidez del deseo”, "Luis Zapata: ‘¿acaso sabemos adónde vamos?"” y "Marcas de género en el relato homosexual”, entre otros. Este último es, sobre todo, importante para el estado de la cuestión aquí formulado, puesto que se trata de un análisis de la antología de cuento gay De amores marginales compilada por Mario Muñoz; no obstante, el artículo será visto páginas más adelante cuando se llegue a los estudios centrados en el homoerotismo dentro del cuento mexicano.

\footnotetext{
131 Marquet, iQue se quede el infinito sin estrellas!, p. 35.
}

132 Loc. cit. 
El segundo volumen de artículos de Marquet, El crepúsculo de Heterolandia, mantiene una visión parecida a la planteada en su predecesor; sin embargo, hay ya una apuesta directa por el 'encuiramiento' -tomando las palabras de Amy Kaminsky- de la sociedad mexicana. El mismo subtítulo del libro, Mester de jotería, apunta hacia una actividad lúdica, pero claramente deconstructiva, de las relaciones de poder cimentadas en el dispositivo de la sexualidad. Para Marquet, debe existir una comprometida labor de jotería que promueva una desestabilización de las estructuras de género e identidades prestigiadas. Con ello, la visibilidad de la disidencia apelará a una nueva discursividad -más flexible y permisiva- sobre el cuerpo, tal como el autor lo señala en el liminar: "A pleno título pensamos que el conjunto de producciones culturales constituyen un mester de jotería, un mester de mariconería. Nuestra palabra gay [...] ha de producir una revolución cultural cuyas resonancias, además del ocaso de Heterolandia, aún ignoramos. Sin duda provoca la liberación del sujeto". ${ }^{133}$ Esta perspectiva es ampliamente estudiada en el prólogo y en "Reflexiones en torno a la homofobia", en cuyas páginas Marquet establece puntos de partida teóricos que establecen términos para una lectura más cómoda y satisfactoria de los artículos posteriores. ${ }^{134}$

En El crepúsculo de Heterolandia hay dos apartados dedicados a la literatura, "Narrativas del mester de jotería" y "La poesía del mester de jotería”, donde están incluidos cerca de una veintena de artículos al respecto. Dentro del primer apartado señalado, el autor analiza textos de Inés Arredondo, Luis Zapata, Eduardo Antonio Parra, Joaquín Hurtado, José Joaquín Blanco, Uriel Quesada y César Aira; en el segundo de Luis Cernuda y Xavier

\footnotetext{
${ }_{133}$ Marquet, El crepúsculo de Heterolandia, p. 16 
Villaurrutia, así como un amplio acercamiento a la compilación Sol de mi antojo. Antología poética de erotismo gay realizada por Víctor Manuel Mendiola.

Sobre este último texto, cabe mencionar que se trata de la primera compilación de poesía de contenido homoerótico en México. Publicada por la editorial Plaza y Janéz en el 2001, Sol de mi antojo es una mirada ferviente a la libertad del deseo inscrita en la poesía mexicana del siglo XX. Mendiola reúne en esta compilación poemas escritos tanto desde una perspectiva lésbica como desde la gay. Los autores incluidos por el antologador son Amado Nervo, Efrén Rebolledo, Porfirio Barba Jacob, Renato Leduc, Carlos Pellicer, Salvador Novo, Luis Cernuda, Efraín Huerta, Guillermo Fernández, Gerardo Deniz, Nancy Cárdenas, Abigael Bohórquez, Reyna Barrera, José Ramón Enríquez, Luis Roberto Vera, Arturo Ramíres Juárez, Uriel Martínez, José Joaquín Blanco, Alberto Ruy Sánchez, Manuel Ulacia, Horácio Costa, Francisco X. Alarcón, Darío Galicia, Sabina Berman, Silvia Tomasa Rivera, Alfonso D’Aguino, Gabriel Santander y Juan Carlos Bautista.

Dentro del prólogo escrito para Sol de mi antojo, Mendiola señala la importancia del homoerotismo en la poesía mexicana, y advierte que con la sola presencia de autores como Villaurrutia, Novo y Pellicer está justificado el tratamiento a dicho tema. En el mismo sitio, señala la falta de no incluir poemas cuyo contenido fuera un descrédito del aspecto homoerótico, dado que estos textos también caerían dentro de la llamada "poesía con tema homosexual". ${ }^{135}$ Esta situación coincide muy de cerca con lo señalado por Marquet al

135 "Quizás hubiera sido interesante, para completar el acercamiento a la poesía con tema homosexual, incluir no sólo los poemas que aceptan el tratamiento de este tópico sino aquellos que lo rechazan o que de plano lo repudian. En esa selección de las intervenciones homofóbicas tendría que haber estado presentes expresiones como 'Peor destino del hombre regido por Saturno / de varón y hembra hace veces por turno. /Su mefítica influencia envenena la tierra; / hay gran copia de efebos cuya impúdica aterra. / Más dicen que son males que trajo la posguerra', de Renato Leduc; o 'a tus desenfrenados maricones que devastan / las escuelas, la plaza Garibaldi, / la viva y venenosa calle de San Juan de Letrán', de Efraín Huerta; o ‘Cuidado, Lesbia, no nos quites un solo pétalo de las manos!', de Jaime Sabines. La 
respecto de cómo definir una obra artística gay, partiendo no sólo de los textos que apoyen dicha preferencia, sino con la inclusión de las obras detractoras y denigratorias de la misma condición homosexual. ${ }^{136}$

Para Marquet, la antología de Mendiola es importante tanto por su posición pionera ${ }^{137}$ como por el variopinto contenido de los poemas seleccionados, en cuyos versos hay una apelación desde el erotismo más sumiso hasta la provocación más emblemática. A su vez, no hay un constreñimiento al ámbito puramente masculino: la compilación incluye textos desde la perspectiva lésbica, cuya presencia enriquece profundamente la antología. Este notorio acierto convoca a una visión más plena del fenómeno de la disidencia sexual como tema dentro de la poesía mexicana.

En 2006, Óscar Eduardo Rodríguez publica El personaje gay en la obra de Luis Zapata. Este volumen se trata, sin duda, del acercamiento más amplio realizado a la extensa y magnífica obra del autor guerrerense. En cerca de trescientas páginas, Rodríguez busca en las novelas y cuentos de Zapata la casi mítica figura del personaje gay: desentraña sus

literatura homosexual no sólo está formada por aquellos textos que aceptan la homosexualidad sino también por aquellos otros que la han negado o que la niegan".

136 Sin embargo, esta cuestión puede sujetarse a una reflexión más profunda sobre terminologías: no hay duda de que una determinada obra, cuyo contenido realice un acercamiento peyorativo hacia la disidencia sexual, deba ser incrustada en el ámbito de lo denominado como "obra artística gay", pero ¿acaso este mismo discurso, que observa la homosexualidad de forma abyecta, puede ser incluido dentro de lo conocido como "obra queer"? La respuesta implica algo absolutamente contrario: no es posible incluir un obra denigratoria de un sexualidad heterodoxa dentro de lo queer, puesto que este mismo concepto pugna por un cuestionamiento directo de las hegemonías. La desestabilización de la sociedad patriarcal y heteronormativa, objeto de lo queer, no puede ser ampliada mediante una abyección de la diversidad. Por esta razón, dentro de lo denominado como "obra queer", sin importar del discurso artístico que apele, no puede darse una afirmación del rechazo hacia la disidencia, a menos de la existencia de una posible parodia del mismo acto de la enunciación, en el cual habría una resemantización del insulto en favor de una práctica no hegemónica.

${ }^{137}$ Se utiliza este adjetivo en cuanto a su calidad de primera antología de poesía homoerótica en el ámbito mexicano, dado que, anteriormente, ya se había dado la presencia, en el itinerario cuentístico, de la compilación De amores marginales de Muñoz. 
características, ubica su relación con la familia y la sociedad e indaga en sus aperturas y temores. ${ }^{138}$

El investigador orienta su trabajo a partir de cuatro ejes de análisis: aspectos formales y estructurales, aspectos estilísticos, aspectos psicológicos y aspectos sociológicos. Con base en cada uno de estos ejes, Rodríguez plantea el ejercicio de la disidencia sexual, dentro de la narrativa de Zapata, como un hecho revelador y que constituye una cuestión temática ineludible para el investigador que no puede eludir. Además, este componente convierte a los textos del autor mencionado en un bastión de la literatura homoerótica mexicana y latinoamericana.

También en 2006, la editorial Iberoamericana sacó a la luz el volumen Desde aceras opuestas. Literatura/cultura cultura gay y lesbiana en Latinoamérica, prologado y editado por Dieter Ingenschay. Este texto es un excelente ejemplo de análisis del homoerotismo dentro de la literatura de la región, y se enriquece, además, con la presencia de prestigiados investigadores que, a lo largo de su trayectoria académica, han incidido en numerosas ocasiones en el tratamiento de la literatura gay latinoamericana, como José Amícola, Birger Angvik, Fernando Blanco, Leopoldo Brizuela, Brad Epps, David William Foster, Victor Fowler, Alejandro Herrero-Olaizola, Jörg Köbke, Antonio Marquet, Elena M. Martínez, Nicolás Rosa, Francisco Soto, Peter Teltscher, Carmen Tisnado y María Ángeles Toda Iglesia. Un acierto más radica en las múltiples perspectivas ofrecidas dentro del volumen, ya que provienen tanto de la misma cosmovisión latinoamericana como desde el exterior.

\footnotetext{
${ }^{138}$ Las novelas estudiadas por Rodríguez son Hasta en las mejores familias, El vampiro de la colonia Roma, Melodrama, En Jirones, La hermana secreta de Angélica María, ¿Por qué mejor no nos vamos?, La más fuerte pasión y Siete noches junto al mar. Al igual, el autor incluye un gran acercamiento a los cuentos incluidos dentro del volumen Ese amor que hasta ayer nos quemaba.
} 
Los artículos incluidos en Desde aceras opuestas realizan un profundo acercamiento al tema del homoerotismo usando categorías de análisis provenientes de los estudios culturales, de género y queer. Un hecho muy destacado por Ingenschay es, también, la presencia de la posmodernidad como suceso de análisis y herramienta del mismo. Esta categoría histórico-cultural es señalada en el prólogo a modo de un acontecimiento generador de creación que, en el caso del aparato crítico, provee una muy buena veta de investigación literaria. Así, la posmodernidad se erige como un concepto capital dentro del texto, puesto que a partir de ella se efectúa un incipiente cambio en el paradigma de la sexualidad y la compresión de los procesos del poder. Al respecto del ámbito literario, Elena M. Martínez, cuando hace su análisis de la novela El amor es una droga dura de Cristina Peri Rossi, señala:

Por literatura posmoderna se entiende aquí la producción literaria que refleja una crisis cultural y que cuestiona abiertamente las formas de representaciónes sociales, estéticas y políticas. Entre los rasgos sobresalientes de esta literatura posmoderna que se empieza a producir en la década del sesenta están la heterogeneidad, la tendencia hacia lo anti-hegemónico, el cuestionamiento de la capacidad representativa, la presencia de lo lúdico, lo marginal, un ataque al concepto de las verdades absolutas, un impulso paródico, la representación del género sexual como acto performativo y la desestabilización de las fronteras de los géneros literarios. ${ }^{139}$

Desde esta perspectiva histórico-social se hace una deconstrucción, en la mayoría de los artículos del volumen citado, de la homosexualidad en la literatura latinoamericana, dado que, buena parte del corpus estudiado, fue publicado después de la década de los sesenta, cuando eclosionaron con gran ímpetu los procesos conformadores de la posmodernidad. Así,

\footnotetext{
${ }^{139}$ Elena M. Martínez,“Género y posmodernismo: intención paródica en El amor es una droga dura de Cristina Peri Rossi”, en Dieter Ingenschar y otros, Desde aceras opuestas. Literatura/ cultura gay y lesbiana en Latinoamérica (Madrid: Iberoamericana, 2006), p. 209.
} 
como bien lo acota Martínez, la posmodernidad plantea una ruptura con las verdades hegemónicas y una visión lúdica del género, situaciones de vital importancia al momento de realizar el correspondiente análisis de alguna obra involucrada con el homoerotismo o la puesta en tela de juicio de la heteronormatividad. ${ }^{140}$ No es gratuito entonces este señalamiento a las fechas de publicación de las obras prominentes y pioneras de la literatura homoerótica latinoamericana, puesto que se trata de un estadio histórico con una profunda actitud de duda y cuestionamiento sobre los principios más axiomáticos de las sociedades occidentales.

El corpus seleccionado por los investigadores citados incluye los textos más representativos de lo que podría denominarse como un canon de la literatura gay latinoamericana. De este modo, se da cita en el volumen a José Donoso, Manuel Puig, Pedro Lemebel, Gloria Anzaldúa, Jaime Manrique, José Lezama Lima, Néstor Perlongher y Reinaldo Arenas, entre otros. En lo concerniente al caso de la representación del homoerotismo en la cultura/literatura mexicana está la destacada presencia de Luis Zapata y el artículo de Marquet sobre la pintura de Carlos Márquez. De Zapata, Bradd Epps analiza la configuración de la figura queer a través de la imagen del vampiro, y enlaza, de forma simbólica, este concepto con la tradición de la picaresca. Por su parte, Marquet estudia los mecanismos mediante los cuales Márquez, a través de su labor plástica, deconstruye los principios hegemónicos de clase, género, etnia y deseo endémicos de la cultura mexicana.

Dentro de esta misma coyuntura de análisis, la Revista Iberoamericana, en 2008, editó su número 225 con el título “Los estudios lésbico-gays y queer latinoamericanos”. El

\footnotetext{
140 Otro gran acierto de Desde aceras opuestas es el riguroso tratamiento académico usado al momento de realizar los análisis: el recurso favorece una estructura dialógica entre la teoría propuesta y su relación con el texto literario en estudio.
} 
volumen es un buen punto de referencia teórico y crítico para abordar la perspectiva y literatura queer en América Latina, dado que no sólo está dedicado a indagar en el homoerotismo dentro de la tradición literaria de la región, sino que propone un enriquecedor y polémico diálogo con los instrumentos teóricos usados para el análisis. Ejemplo de ello, es el primer apartado, titulado "Polémicas", en el cual se hace un recorrido por los principales postulados teóricos de lo queer, para plantear las peripecias de su uso en América Latina. En este apartado, Amy Kaminsky explora las posibilidades de una traducción adecuada para el término queer, y ensaya diversas propuestas de palabras usadas en el amplio español de Hispanoamérica para denigrar la postura del disidente sexual, como el pato, el joto, el maricón, la machorra y la tortillera. No obstante, su objetivo principal estriba en proponer el término "encuirar" como una necesidad de visibilidad de la heterodoxia sexual para desestabilizar la sociedad heteronormativa y patriarcal. Epps, por su parte, sigue una línea de argumentación similar a la de Kaminsky, pero centra su atención en los riesgos de aplicación de la teoría queer. Con base en algunas representaciones homoeróticas tanto en la literatura como en la cultura latinoamericana, Epps advierte la forma en que se ha producido la ruptura con el dispositivo hegemónico de la sexualidad en la región y la opone frente a la disposición teórica de lo queer.

Posteriormente, David William Foster, Denilson Lopes, Lázaro Lima y Flavio Rapisardi, en el apartado "Mapas críticos", contextualizan los estudios culturales realizados sobre las representaciones homoeróticas en la sociedad latinoamericana. A este respecto, Foster hace, en su artículo "El estudio de los temas gay en América Latina desde 1980", un definición de términos como gay y homosexual, a la vez que delimita los espacios de aplicación de los estudios de género, la teoría queer y los estudios culturales. Como se 
advierte, este espacio está destinado sobre todo a un recorrido histórico por las identidades disidentes y las diversas teorías usadas para su estudio en la región.

En el siguiente apartado "Cartografías literarias", son incluidos artículos de Gisela Kozak Rovero, Karl Posso, Yolanda Martínez-San Miguel y Daniel Balderston. Este conjunto de textos tiene como objetivo brindar un panorama general del homoerotismo en las literaturas venezolana, brasileña, caribeña y colombiana, respectivamente. Este apartado es profundamente enriquecedor en cuanto que proporciona una visión del desarrollo de las representaciones homosexuales en los espacios literarios mencionados; además, los artículos pueden servir como excelentes guías de lectura si se desea rastrear la disidencia sexual en estos contextos escriturales.

Ahora bien, sobre la literatura mexicana homoerótica está incluido, en el apartado "Lecturas", el texto titulado "La dicotomía estructuradora en Salvador Novo: afeminamiento y virilidad" de Humberto Guerra. El texto hace un análisis de La estatua de sal con base en las imágenes estereotipadas de la homosexualidad. También, con base en el mismo texto, Guerra realiza una deconstrucción del dispositivo de la sexualidad mexicano para advertir los diversos procesos que infieren en la conformación de una identidad abyecta o, en su caso, prestigiada. El investigador busca en La estatua de sal los mecanismos libertarios usados por Novo y, a la vez, indaga en el modo en cómo el poeta usa una identidad poco plausible dentro de la estructura genérica del país para erigirla en estilo de vida. Guerra, analiza, a la vez, las formas de establecer jerarquías dentro del gueto descubierto por Novo, y acota ciertos valores de género internalizados al establecer una relación afectiva, puesto que hay un rechazo hacia el otro "afeminado" y una búsqueda constante de la contraparte "varonil".

Otro texto que merece, además, una especial atención es el volumen coordinado por Michael K. Schuessler y Miguel Capistrán titulado México se escribe con J. Una historia de 
la cultura gay, publicado en el 2010. Este libro, desde el título, realiza una subversión de los valores más intrínsecos al nacionalismo del país: cuando se vulnera una de las barreras de construcción de la identidad mexicana más sensibles, como lo es el mismo nombre de la nación, hay un deliberado deseo de desestabilización de la incómoda estructura genérica del país. Este paratexto, evidentemente, apela a la relación entre la jota que puede constituir -en una forma ortográfica adecuada, pero inadecuada tomando en cuenta la impronta nacionalista- el nombre de México y la inicial de uno de los adjetivos más cotidianos y peyorativos usados hacia la figura del homosexual en el país, el "joto". De este modo, México se escribe con $J$ articula un discurso de búsqueda y muestra de las representaciones del homoerotismo en la cultura nacional, no como un hecho aislado, sino partiendo de la relación inalterable entre el deseo y el sujeto, cuya visibilidad, la mayoría de las veces, ha sido negada, aún a sabiendas de que esta cultura homoerótica existe per se.

Los artículos compilados en el volumen citado recorren los espacios homoeróticos en la cultura y las artes, desde la literatura decimonónica hasta los programas televisivos actuales. Los autores que se dan cita son Luis Zapata, Michael K. Schuessler, Miguel Capistrán, Braulio Peralta, Teresa del Conde, Víctor Jaramillo, Álvaro Cueva, Tareke Ortiz, Nayar Rivera, Pável Granados, Juan Carlos Bautista, Alejandor Varderi, Alejandro Brito, Salvador Novo, José Joaquín Blanco, Carlos Monsiváis, Enrique Serna, José Ricardo Chaves, Víctor Federico Torres y Sergio Téllez Pon. En el caso de este trabajo, las aportaciones de los tres últimos resultan fundamentales dado que son un nutrido acercamiento a la literatura mexicana de tema homoerótico.

El artículo de Chaves, "Afeminados, hombrecitos y lagartijos. Narrativa mexicana del siglo XIX", hace un recuento de las vicisitudes de un posible "personaje gay" en la literatura decimonónica del país. El investigador recupera, para ello, los diversos 
revestimientos dados al "invertido" en la cultura mexicana de este estadio histórico y alega cómo se da, desde esta perspectiva, un acercamiento hacia las costumbres de tan rechazado y terrible personaje. El recorrido inicia en los cuentos que Chaves denomina "de vestidas", cuya diégesis, de forma tangencial o directa, toca la presencia del personaje travestido. Los ejemplos citados son "Manolito el Pisaverde" (1838), de Ignacio Rodríguez Galván, y “Aventura de carnaval” (1890-189), de Amado Nervo. Posteriormente, acota la existencia de personajes aniñados con pocos deseos de crecer que aparecen bien retratados en las novelas El fistol del diablo (1845-1846), de Manuel Payno, e Historia de Chucho "el Ninfo", de José Tomás de Cuéllar. Después de citar estos personajes, Chaves se introduce en el homoerotismo presente dentro de la canción popular. Para tal efecto, recurre a los famosos versos de Teófilo Pedraza titulados El ánima de Sayula -y difundidos en Michoacán a fines del siglo XIX- y a las catorce estrofas que acompañaron los grabados de Guadalupe Posada sobre el escandaloso baile de 1901. Una vez terminado el recorrido, el autor reflexiona sobre la presencia del "afeminado" en la literatura decimonónica mexicana y acota cómo, con base en la representación de la masculinidad en el país, el sujeto con ciertos deslices genéricos estas rupturas con la "hombría" nacional son, como ya se dijo anteriormente y se retomará más adelante, eufemismos para señalar indirectamente al "invertido sexual"- es enviado al margen de toda manifestación política y social: su presencia sólo es justificada con el objetivo de magnificar el modo sexogenérico imperante.

El artículo continuador del recuento y análisis de la representación del disidente sexual y genérico en la literatura mexicana es "Del escarnio a la celebración. Prosa mexicana del siglo XX" de Víctor Federico Torres. En este trabajo, desde el título, el autor anticipa el camino recorrido por una figura mejor delineada del "invertido", cuya travesía inicia aún en la concepción del homoerotismo como una conducta abyecta, enfermiza y repugnante para 
concluir en una reivindicación absoluta de la misma. Torres comienza su recorrido narratológico con la famosa pseudonovela de Eduardo A. Castrejón, Los cuarenta y uno-que bien puede pertenecer aún al siglo XIX, dada la convención histórica sobre el inicio y final del mismo en México con base en los procesos políticos referidos a la dictadura porfirista y a la Revolución. Torres señala lo ya reiterado en el capítulo anterior sobre el texto en cuestión: el tratar a los homosexuales de la oligarquía porfiriana a modo de chivo expiatorio con el fin de "exaltar las virtudes de la clase obrera", usando la base inescrutable de la sexualidad hegemónica mexicana. Posteriormente, el autor señala La estatua de sal de Salvador Novo y Fabrizio Lupo de Carlo Cóccioli, de las cuales señala su carácter pionero en cuanto al tratamiento del homoerotismo en la literatura mexicana se refiere. A su vez, remite al ensayo de Severino Salazar, "Narrativa gay en México", para advertir cómo a lo largo de la década de los cincuenta hay una incorporación de personajes homosexuales en autores como Arreola, Fuentes, Castellanos y, más específicamente, en la novela El norte (1958) de Emilio Carballido; aunque, claro está, este acercamiento al tema de la disidencia sexual no forma parte de la historia principal de los textos en cuestión.

Torres, siguiendo la línea de investigación planteada por Schneider, marca como verdadero inicio de la narrativa homoerótica mexicana a la ya citada novela de Barbachano Ponce, El diario de José Toledo, seguida por 41 o el muchacho que soñaba con fantasmas de Paolo Po y Después de todo de Ceballos Maldonado. Cabe destacar el amplio espacio dedicado en el texto a estas tres novelas no sólo debido a su carácter de pioneras, sino a modo de establecer un paralelismo entre las visiones de la disidencia sexual implantadas en ellas con el modelo político y cultural tenido al respecto en la sociedad mexicana de su tiempo. Más adelante, el autor prosigue con el ya emblemático El vampiro de la colonia Roma de Zapata, Octavio de Jorge Arturo Ojeda y Flash Back de Raúl Rodríguez Cetina. Una vez 
concluida la disertación del autor acerca de estas tres novelas, acota lo siguiente: "Cinco novelas, todas ellas publicadas en la década del 80 , ejemplifican el surgimiento de nuevas propuestas y reflejan la madurez que alcanza el tema gay en la narrativa mexicana: Melodrama, Utopía gay, Las púberes canéforas, En jirones y Brenda Berenice o el diario de una loca. Se trata de novelas que continúan la renovación del tema gay, con personajes fuera del clóset que reclaman su espacio en la sociedad y la legitimidad de la pareja homosexual". ${ }^{141}$ Es evidente, durante estos años, la prolífica existencia de una tradición literaria homoerótica muy consolidada. Las novelas señaladas por Torres muestran el terreno ganado por el personaje gay en los diferentes cronotopos presentados por los textos y, además, reiteran un ardid de recursos literarios usados a propósito de los contenidos transgresivos, es decir, la amalgama contestataria desde la historia y el discurso. Hasta aquí, concluye el recorrido el autor, no sin antes señalar la magnífica emergencia del deseo homoerótico en la narrativa de las décadas posteriores y, también, el deliberado uso del ámbito literario como espacio de cuestionamiento y demostración de antiguas y nuevas -0 , muchas veces, soterradas-identidades sexo-genéricas.

Sobre esta última aseveración, Sergio Téllez-Pon en su artículo "La fuerza oculta del otro amor. La poesía homoerótica", que precede al de Torres, alude al carácter persistente del tema de la disidencia sexual en la lírica mexicana, cuya presencia no es marginal y, al contrario de lo pensado, está inserta dentro del canon de la misma. Para ejemplificar lo anterior, el autor señala un enorme corpus en cuyo inicio están los famosos sonetos "Andrógino" de Amado Nervo y "El beso de Safo" de Efrén Rebolledo y, al final, las aportaciones de Guillermo Fernández, Abigael Bohórquez, Jorge Cantú de la Garza, Luis

\footnotetext{
${ }^{141}$ Víctor Federico Torres, "Del escarnio a la celebración. Prosa mexicana del siglo XX", en México se escribe con J, pp. 94-95.
} 
González de Alba y José Ramón Enríquez, entre otros. El trabajo de Téllez-Pon perfila entonces la gran coyuntura del homoerotismo inserto en la poesía mexicana, cuyos más amplios representantes fueron, sin duda, los integrantes de la generación de los Contemporáneos. Cabe mencionar que el autor del artículo en cuestión, aparte de señalar el gran corpus poético mexicano de tema homosexual, acota diversos autores pertenecientes al canon de la literatura en Occidente considerados exponentes del tópico y que, además, en algunas ocasiones influyeron la lírica mexicana homoerótica como Whitman, Kavafis, Rimbaud, Verlaine y Cocteau, entre otros.

Estos tres artículos publicados en México se escribe con $J$ son una breve pero jugosa muestra de la existencia y gran auge de la literatura mexicana de contenido homoerótico. Sin duda, faltó agregar numerosos autores cuya colaboración ha enriquecido notablemente esta tradición literaria; no obstante, el recorrido hecho por Chaves, Torres y Téllez-Pon ilustra la coyuntura homosexual en las letras mexicanas y promueve, sin duda, la curiosidad de consulta en los lectores que no han tenido contacto con los textos señalados.

Según el orden propuesto para el desarrollo del estado de la cuestión sobre los acercamientos realizados acerca del homoerotismo en la literatura mexicana, hasta aquí terminaría el recorrido general. Ahora, inicia la mención y análisis de los textos que se han dedicado, mayormente, al estudio de la representación de la homosexualidad en el cuento. Estos trabajos son menos numerosos que los anteriores, dado que muchos de los textos analizados anteriormente brindan un panorama general del homoerotismo en las letras mexicanas y, en algunas ocasiones, optan por el tratamiento de la poesía, el teatro o la narrativa sin detenerse demasiado en la ficción breve.

Sin duda, el investigador que más ha estudiado y documentado la trayectoria del tópico homoerótico en el cuento mexicano es Mario Muñoz, quien en 1996 con su antología 
De amores marginales realiza un acontecimiento pionero no sólo en México, sino en Hispanoamérica, al congregar una compilación de dieciséis textos literarios -en este caso de relatos- cuya temática afrontara el tema de la homosexualidad. Dicho volumen, a pesar de ser publicado casi a finales del siglo pasado y después de varias décadas de lucha en pro de los derechos y libertades de la disidencia sexual, tuvo una serie de contratiempos en su publicación por lo "escabroso" del tema. La más importante de ella puede observarse claramente en la portada y contraportada del libro, en las cuales no es mencionada la palabra "homosexual" y, con eufemismos, se aborda ligeramente el contenido: "Más allá de cualquier etiqueta reduccionista ante las distintas manifestaciones del amor, lo que estos cuentos tienen en común el tema de las posibilidades del erotismo: como ligue, como pasión, como venganza, pero sobre todo, el erotismo como aceptación de la exigencia de los propios sentidos del ser humano. Para decirlo con Octavio Paz: "El amor nace de una atracción voluntaria. Esto último es su condición necesario, el acto que transforma la servidumbre en libertad". ${ }^{142}$ Asimismo, el propio título de la antología refiere al tema de forma connotativa con el adjetivo "marginales". Con todo, la compilación es un pródigo banquete de narrativa breve homoerótica que muestra las posibilidades de la seducción, la pasión, el deseo y el amor fuera de los límites de las hegemonías sociales.

Ahora bien, sólo dos de los autores de los cuentos seleccionados nacen durante la década de los veinte, los catorce restantes lo hacen a lo largo de los cuarenta, cincuenta e inicio de los sesenta. Esta situación, obviamente, está en correlación con las fechas de publicación de los relatos, las cuales inician a mediados de los setenta y tienen su mayor bastión durante los ochenta. De este modo, los cuentos reunidos por Muñoz, en orden

\footnotetext{
${ }^{142}$ Contraportada de De Amores Marginales.
} 
estrictamente cronológico, son los siguientes: "Mapache" (1975) de Jorge Arturo Ojeda, "Siete veces el sueño" (1979) de Luis Arturo Ramos, "El vino de los bravos" (1981) de Luis González de Alba, "Respiración artificial” (1982) de Raúl Hernández Viveros, “Un caso semejante" (1983) de Agustín Monsreal, “Tu bella boca rojo carmesí” de Ana Clavel, "El hábito oculto" (1984) de Ignacio Betancourt, "Juego de ajedrez" (1984) de Fidencio González Montes, “También hay inviernos fértiles" (1986) de Severino Salazar, "Opus 123" (1988) de Severino Salazar, "De amor es mi negra pena" (1989) de Luis Zapata, "El alimento del artista” (1991) de Enrique Serna, "Doña Herlinda y su hijo" (1993) de Jorge López Páez, "Sólo era un juego" -inédito hasta la fecha de publicación de la antología- de Víctor Rejón y "Callejón" -igualmente, inédito-. Todos estos textos ofrecen al lector la diversidad del homoerotismo que atraviesa el espacio de lo sórdido y lo prohibido en un afán de encontrar la verdadera orientación de la aguja en la brújula de la sexualidad. Muchas veces, los personajes de los cuentos seleccionados atraviesan tanto el rechazo u opresión por parte de un dispositivo de género dominante como por la propia interiorización de esa norma que, a cada instante, les recuerda consciente o inconscientemente su calidad de "anómalos". Este leitmotiv anclado en las diégesis de los relatos propicia finales dolorosos o trágicos para los personajes disidentes: el ostracismo del círculo familiar o geográfico, la clausura del deseo promovida desde una demandante mirada social sancionadora o, incluso, la muerte son algunas de las salidas más destructivas. Otras veces, en una exultante exhibición del deseo los protagonistas se aferran a instaurar su sexualidad como un hecho no punible y, por tanto, satisfactorio, echando por tierra cualquier esencialismo.

En continuidad con esta línea de investigación, Muñoz publica en la Revista de Literatura Mexicana Contemporánea el artículo "El cuento mexicano de tema homosexual" (1997). Desde el título, el autor designa claramente el objeto de su trabajo y, antes de adentrar 
al lector en el mismo, le ofrece una breve visión sobre el tema, al ofertar cómo las diferentes sociedades han elaborado un extenuante catálogo de sexualidades normales y anómalas. Posteriormente, Muñoz hace un repaso por lo que puede ser considerado como "literatura gay", aludiendo a los diversos vericuetos terminológicos creados por la crítica con el afán de concretar los límites de su objeto de estudio. En este contexto, el autor señala bajo este concepto a un conjunto de textos en los cuales se presenta de forma directa o indirecta el tema de la homosexualidad. Más adelante, señala como novela angular de la tradición literaria gay a El vampiro de la colonia Roma del ya citado Luis Zapata, pero coloca como antecesores directos de la misma a los siguientes autores:

La paulatina liberación de la moral mercenaria permitió que fueran publicándose por esos años las primeras novelas gays escritas en México como El diario de José Toledo, de Miguel Barbachano Ponce, en 1964, y Después de todo, de José Ceballos Maldonado, en 1969. De modo tangencial otros novelistas habían tocado el tema, pero sin la hondura de los dos mencionados modelos narrativos, precursores indiscutibles de Luis Zapta. Pienso, por ejemplo, en El norte (1956) de Emilio Carballido, en La comparsa, de Sergio Galindo, y en el relato "A la víbora de la mara", contenido en Cantar de ciegos, de Carlos Fuentes, ambos libros de 1964. Esta coincidencia de circunstancias sociales, culturales y literarias, explica la curva ascendente del discurso que alude a la homosexualidad y la creciente formación de un imaginario que va integrándose con los aportes de novelas y cuentos de variado alcance estético. $^{143}$

Una vez hecho este recorrido por las manifestaciones del homoerotismo en la narrativa mexicana, especialmente la novela, Muñoz entra al ámbito del cuento y toma como base la antología ya citada en este apartado: De amores marginales. El autor advierte sobre la

143 Mario Muñoz, "El cuento mexicano de tema homosexual", en Revista de literatura mexicana contemporánea (El Paso: The Universitity of Texas at El Paso, septiembre-diciembre 1997), n. 6, vol. II, p. 20. 
apertura del cuento mexicano hacia el tema gay a partir de la década de los sesenta y los setenta, con el movimiento de la contracultura impulsado por los autores correspondientes a la "generación de la Onda", que, como es bien sabido, impusieron una nueva forma de entender el mundo y produjeron severos cambios en la mentalidad de la sociedad mexicana, entre ellas los mitos al respecto del cuerpo, el género y la sexualidad, así como a los modos de hacer literatura. Más adelante, Muñoz acota nuevamente a los autores de los cuales obtuvo los cuentos para formar su antología y hace un breve análisis de algunos de estos textos, entre ellos destacan "Doña Herlinda y su hijo" de Jorge López Páez, "Opus 123” de Inés Arredondo, "Siete veces el sueño" de Luis Arturo Ramos, "Los zapatos de la princesa" de Guillermo Samperio, entre otros.

Otro artículo de Muñoz que conviene destacar aquí es "La literatura mexicana de transgresión sexual", publicado en la revista francesa Amerika en 2011. En este texto, el crítico hace un repaso por los diversos aportes del cine al tema homoerótico antes de ingresar al espacio de la literatura; no obstante, una vez instalado en éste hace un nutrido estudio por los diferentes textos que han moldeado un amplio corpus relacionado con dicha cuestión. Cabe mencionar que, debido a las fechas de publicación de este trabajo, el crítico incluye novelas más recientes que se integran de forma acertada a la lista, como lo serían Fruta verde (2006) de Enrique Serna y Toda esa gran verdad (2006) de Eduardo Montagner, así como cuentos publicados en la década pasada, tal sería el caso de Los pavorreales y otros cuentos gay para llevar (2003) de Jesús de León.

En esta misma línea de los trabajos dedicados exclusivamente al estudio del cuento mexicano con contenido homoerótico, se hallan "Sesenta años del cuento mexicano de temática gay” de León Guillermo Gutiérrez y “Masculinidades homosexuales en la narrativa de Eduardo Antonio Parra, Joaquín Hurtado y Nadia Villafuerte” de Gerardo Bustamante 
Bermúdez. El primer trabajo elabora un diálogo entre la literatura mexicana y la hispanoamericana que le sirve para exponer, paulatinamente, las diversas eclosiones del homoerotismo en la cuentística nacional. 
Antecedentes

Las escasísimas referencias al tema de la disidencia sexual en la literatura mexicana del siglo diecinueve fueron propiciadas por la existencia de una sexualidad hegemónica, heredera de la concepción de la disidencia sexual como pecado y cuya percepción derivaría más adelante en delito. En el primer capítulo de este trabajo se acotó ya la visión tenida sobre el "sodomita" colonial y el "invertido" decimonónico: ambas estrategias de dominación y caracterización del erotismo marginal propiciaron un enconado odio y desprecio hacia cualquier manifestación en contra del binomio de género y la aún no nombrada "heterosexualidad".

Una vez surgido el México independiente, y con el afán de imprimir estabilidad a la joven nación, el aparato político no dudó en conferir un peso enorme a los supuestos roles "naturales" del hombre y la mujer. Y, seguramente, no pudo haber sido de otro modo, dadas las circunstancias históricas, culturales e ideológicas que habían impregnado al pueblo mexicano durante tantos años. Todos los medios necesarios para edificar "correctamente" al recién independizado país deberían ponerse a funcionar, y la literatura no quedó a la orilla de esta situación. Establecidas estas razones ¿por qué debería exhibirse la impúdica, nefanda y pervertida figura del disidente sexual? ¿Cómo un tema tan desprestigiado tendría cabida en las letras nacionales? O mejor aún, ¿cómo algo "inexistente", socialmente hablando, podría señalarse o describirse? Y aquí cabe recordar lo dicho por Monsiváis: "Lógica del ocultamiento: lo que no se nombra no existe, y lo nada más filtrado, y muy 
despreciativamente, en las conversaciones, es sórdido de suyo". ${ }^{144}$ La mención del "invertido" o "afeminado" es mínima en la literatura, y si llegase a aparecer se le desprestigia y, por obvias razones, queda en la ambigüedad su comportamiento sexual:

En el siglo XIX mexicano, al menos en su literatura, el gay u homosexual tal como se entiende hoy, a principios del siglo XXI (un hombre que tiene o quisiera tener relaciones sexuales con otro hombre), no aparece, no existe, pero su equivalente: el afeminado, un desviante de la norma masculina hegemónica, que compite en coquetería y locuacidad con las mueres, sin llegar a tener relaciones sexuales con otro. En este sentido, el afeminado se define por un comportamiento social (gestos, gusto por la ropa, el baile y los perfumes...) y no por una práctica sexual. ${ }^{145}$

Esta situación señalada por Chaves cabe cómodamente en el ámbito de la novela, con algunos personajes pertenecientes a El fistol del diablo de Manuel Payno y, sobre todo, a La historia de Chucho "el Ninfo" de José Tomás de Cuéllar. No obstante, en el ámbito del cuento la situación, al menos en los ejemplos que aquí serán presentados, es diferente. El juego de la disidencia sexual ingresa por una puerta aun más controvertida: el travestimiento. Mas el usar prendas del género opuesto no obedece a una circunstancia homoerótica, sino a un ardid utilizado con la meta del camuflaje para obtener algún servicio, reparar faltas o poner en jaque a determinados sujetos, tal como lo evidencian "Manolito el pisaverde" de Ignacio Rodríguez Galván, “Aventura de Carnaval” de Amado Nervo y "La excursionista” de Federico Gamboa. Estos tres textos serán utilizados entonces para definir los antecedentes de un posible homoerotismo en el cuento mexicano, en los años que van de 1821 a 1910. Sin

\footnotetext{
${ }^{144}$ Monsiváis, Que se abra esa puerta, p. 51.

145 Chaves, "Afeminados, hombrecitos y lagartijos. Narrativa mexicana del siglo XIX", en México se escribe con J, p. 66.
} 
embargo, debe usarse la pertinencia en el análisis e interpretación de estos textos para el fin perseguido en esta investigación, dado que el juego implicado en el cambio de identidades como ya fue puntualmente señalado- atañe a objetivos no relacionados con la sexualidad; aunque, de forma casi automática, la presencia lúdica remite a un ligero sesgo homoerótico y, con ello, a un asomo hacia la forma de concebir el sexo y el género en los contextos diegéticos acotados. De este modo, y siguiendo el orden cronológico de los textos, se empezará con "Manolito el pisaverde" que fue concluido por su autor en noviembre de 1837, pero publicado en el Año Nuevo de 1838.

Para Luis Leal, la obra de Ignacio Rodríguez Galván (1816-1842) pertenece al romanticismo mexicano y explica algunas características de este que, fácilmente, pueden encontrarse en el relato del autor que aquí será estudiado: "El cuento anterior a 1867 es, con raras excepciones romántico. Los primeros en cultivarlo fueron Rodríguez Galván y Pesado [...]. En sus cuentos predomina la nota sentimental y la idealización de los personajes. Sin embargo, las descripciones del ambiente son realistas, sin dar cabida a nada que sugiera lo fantástico". ${ }^{146}$ "Manolito el pisaverde" cumple a cabalidad los rasgos expresados por Leal. La historia del cuento transcurre en un ambiente absolutamente realista y con fuertes haces de sentimentalismo. Sobre esto último, Leal dice: "Los trillados temas del romanticismo europeo son los que predominan: el amor imposible, el fracaso en amores, la rebeldía, la aventura truculenta, las intrigas, el honor mancillado". ${ }^{147}$ No es de extrañar pues que la función inaugural de "Manolito el pisaverde", en términos de Bremond, sea la búsqueda y deseo de encontrarse con el amado ausente. ${ }^{148}$ María, la protagonista, decide salir de su

\footnotetext{
${ }^{146}$ Leal, Breve bistoria del cuento mexicano, p. 32.

147 Loc. cit.

148 Esta situación no es privativa del relato en cuestión, en "La hija del oidor" Rodríguez Galván desarrolla una diégesis similar en la cual la protagonista rompe con cualquier tipo de barreras,
} 
pueblo natal en Guatemala para realizar una enorme travesía con el fin de hallar a su amado, Jacinto Almaraz, quien partió hacia México a causa del exilio impuesto por su condición opositora al nuevo gobierno de aquel país. Llama aquí la atención este primer hecho transgresivo del cuento, puesto que el autor dota a la mujer de atributos poco frecuentes para su tiempo. María, si bien con anterioridad estaba dedicada al ámbito doméstico y cuidado de su padre, toma la iniciativa y actúa. Las aventuras e infortunios sufridos por ella durante su tránsito de la ciudad natal a la Ciudad de México no son explicados; sin embargo con el sólo hecho de plantear la situación queda claro el carácter poco “femenino", en términos históricos y culturales, de la protagonista.

Este rasgo poco convencional de María es acrecentado con el nuevo revestimiento genérico que adquiere: en su afán de acercamiento a Jacinto, María se traviste en un galante y apuesto joven con el nombre de Manuel, quien rápidamente alcanza un gran prestigio entre la sociedad de la capital mexicana. Por su juventud y dimensiones pequeñas, este gracioso personaje es denominado por todos como Manolito. El lector, como en el caso de la información relativa al viaje de María, obtiene nulos detalles sobre el inicio del travestimiento de este personaje y la incursión del mismo en la sociedad retratada. Incluso, para logar un efecto sorpresivo al final de cuento, ${ }^{149}$ el narrador no menciona en ningún

especialmente el cerco colocado por su padre alrededor de ella, para acercarse al joven que la ha deslumbrado por completo. También, hay una similitud entre los personajes masculinos y femeninos de ambos cuentos: las mujeres adquieren cierta voluntad de "independencia" y actúan para obtener lo deseado; por su parte, los hombres, destinatarios directos de la estrategia femenina, decepcionan a las primeras por presentar una conducta poco correcta que deviene en un completo fracaso de la relación amorosa entablada.

${ }^{149}$ Hay cierta controversia sobre la clasificación del texto de Ignacio Rodríguez Galván, de tal suerte que permanece en los límites entre la novela corta y el cuento; sin embargo, desde la perspectiva estructural, y no tanto desde el número de páginas, el texto se inclina más hacia el ámbito del cuento, sobre todo por el manejo de la historia oculta que emerge al final con el "desenmascaramiento" de los personajes. 
momento la identidad de Manuel, al contrario, alardea acerca de la falta de pormenores concernientes al apuesto joven, y subraya además su inmensa galanura y modales.

Dividido en cuatro breves apartados -“El baile", "La cruz", "Almaraz" y "El Cabrío"-, "Manolito el pisaverde" es un relato profundamente descriptivo y reflexivo sobre el crimen y la virtud, en torno a los cuales gira la conducta del hombre. En este caso, la historia del texto está más ligada al primer concepto que al segundo por la desdicha y tragedia instauradas en los personajes principales: Manuel-María, Jacinto y Teodora. Cada uno de ellos -y sobre todo las protagonistas- padecen los resabios de la ambición, el desamor y la violencia. Obviamente, el iniciador de tales fatigas es Jacinto, quien vulnera, primeramente, la entrega de María y, secundaria a esta acción, promueve en Teodora un hondo desconsuelo. Sin embargo, no sólo María y Teodora padecen por estas actitudes, también, a su modo, Jacinto sufre un martirio interior al oscilar entre la satisfacción y el remordimiento. Entonces, de forma estructural, los capítulos acentúan estas congojas al pasar de una aparente dicha a la desgracia más inefable.

En primer lugar, María se transforma en Manolito para acercarse a Jacinto e intentar la disolución de su matrimonio con Teodora, a quien el segundo seduce con el objetivo de poseer sus acaudalados bienes. Por tanto, el travestimiento opera en un nivel "necesario" aunque posiblemente prescindible si se piensa en otras tácticas para obtener tales fines-, cuyo carácter inusual puede abrevar de lo jocoso en una cercana instancia.

Como se ha mencionado, la relación entre la historia y el discurso planteada por el narrador permite conocer la transformación de María en Manolito pocas páginas antes del final del texto, justo cuando ocurre la desafortunada entrevista entre este personaje y Jacinto: 
—Es preciso arrancarnos la máscara y presentarnos uno al otro con la faz descubierta: basta ya de fingir [dirigiéndose a Manolito]. ¿Quieres saber quién eres tú?... Yo me llamo Jacinto Almaraz, tú te llamas María, la que fue mi esposa en otro tiempo; la que se disfraza ahora para perseguirme; la que era mi bien, mi amor, mi existencia en otra época de nuestra vida; la que detesto en la actualidad como a los enemigos de mi padre; la que debe ausentarse de este país ahora mismo... ${ }^{150}$

Es, hasta entonces, que el lector conoce la identidad ocultada bajo el disfraz de Manolito y, a la par, descubre la enorme travesía que significó para María el desplazamiento de su tierra natal a la capital mexicana. Por tanto, ambos factores transfiguran a la protagonista en una mujer infractora: deja a un lado su condición arquetípica de pasividad y realiza una atrevida odisea, pero, no satisfecha con lo anterior, adquiere una nueva representación de género. Sin embargo ¿cómo opera el nuevo revestimiento en María y cuáles son las implicaciones que dicha circunstancia establece a priori? Cabe recordar aquí, para evitar desviaciones teóricas y, posteriormente, de análisis, la definición de género.

En términos de Judith Butler, este concepto obedece a una condición cultural, cuyas repercusiones en la vida del individuo son tan inmensas y arraigadas que se le llega a considerar como un hecho meramente natural o, al menos, con un anclaje sempiterno en el sexo del sujeto. Bajo esta implicación, no parece difícil advertir las dificultades atravesadas por María para convertirse en Manolito e, igualmente, el conflicto planteado en el plano de lo individual y colectivo. La "naturalidad" del género anclado en el dispositivo de la sexualidad detesta cualquier tipo de mutación en cuanto a la identidad sexo-genérica se

${ }^{150}$ Ignacio Rodríguez Galván, Manolito el pisaverde y otros cuentos (Puebla: Premiá, 1984), p. 23. 
refiere. De este modo, el nuevo revestimiento de María produce instantáneamente dos situaciones controversiales: el problema del sujeto consigo mismo y el conflicto de éste con su entorno. El narrador del cuento poco aborda la primera condición; al contrario, pareciera que María convive sin algún tipo de inconveniente con su travestimiento: a final de cuentas, éste tiene un objetivo muy diferente a una posible situación homoerótica; no obstante, la relación entre el revestimiento masculino de María y su entorno es muy diferente. Desde el primer apartado, la presencia de Manolito en el baile para festejar la boda entre Teodora y Jacinto resulta compleja: no se trata de un joven convencional, sino de una figura muy atractiva tanto para las mujeres como para los hombres presentes en la reunión. Además, cabe destacar en este sitio la discreción del nuevo "traje" de María, el cual reconfigura a la perfección su género. ${ }^{151}$ Así, Manuelito es descrito excelsamente por el narrador de la siguiente forma:

El recién venido era un joven como de unos dieciocho años, de pequeña y proporcionada estatura, de airoso talante, de pálido rostro, de facciones nobles, delicadas y bellas, hermoseadas más por un bigote apenas naciente; su pequeños pies estaban adornados con unas medias de seda gris y con unos zapatos lustrosos; como su pantalón negro sumamente angosto, estaba ajustado en el tobillo por cuatro pequeños botones de oro, un chaleco de seda azul bordado del mismo metal, estaba dispuesto de manera que dejara ver su blanquísima camisa y su corbata de terciopelo; encima del

${ }^{151}$ Butler menciona en El género en disputa la posibilidad de desestabilizar los andamios de la sexualidad que posee la drag queen al intercambiar su identidad por la del "género opuesto"; sin embargo, también considera este suceso como algo "hermético", en cuanto a que plantea la posible existencia de sólo dos representaciones genéricas. En el caso del cuento estudiado, el travestimiento de María genera una destrucción de los principios bajos los cuales está fundamentada la performatividad del dispositivo de la sexualidad. 
chaleco tría un frac negro, cortado según las últimas estampas llegadas en aquella fecha de París, su negra y recortada cabellera estaba por la frente, dividida en dos mitades, siendo más pequeña la parte izquierda que la derecha; en fin, el complemento de su traje eran unos guantes blancos de cabritilla y un sombrero negro de baile, doblado debajo del brazo. ${ }^{152}$

La palabra "pisaverde" incluida en el título del cuento como epíteto de Manolito queda plenamente justificada con esta pormenorizada lista de rasgos. ${ }^{153}$ La presencia del personaje es avasalladora tanto por su notable belleza física como por la gracia de su vestimenta. Sin embargo, ambas circunstancias producen ciertas ambigüedades sobre lo que podría entenderse como un varón: no hay duda de la eficacia del travestimiento de la protagonista, pero ¿acaso la imagen de Manolito corresponde a una masculinidad cabalmente denotada por el dispositivo de género de la época? ¿Implicaría la perfección en el arreglo algún tipo de desliz en cuanto a una identidad viril? ¿Hay, en la insinuación del petimetre, un sesgo de “ambigüedad” genérica que, para la cosmovisión de la época, originaría una relación con el sujeto afeminado? Estos cuestionamientos son resueltos ágilmente por el narrador, quien muestra la fuerte paradoja ejercida por Manolito.

En primer lugar, el personaje es un joven encantador para las jóvenes presentes en el baile, pero, para los hombres, no deja de ser un tanto insidiosa su presencia por la captación de las "miradas femeninas"; en segundo sitio, este desasosiego se extrapola al ámbito erótico

\footnotetext{
152 Rodríguez Galván, p. 31.

${ }^{153}$ La palabra "pisaverde" era usada durante el siglo XIX para designar a aquellos hombres con un arreglo personal sumamente esmerado, el cual redundaba en ser llamativos y, por supuesto, centro de atención en las fiestas. En el caso del cuento, este hecho está muy cercano también al afeminamiento, dado que un arreglo excesivo puede coincidir con la representación de la mujer.
} 
al grado de que los propios detractores de Manolito se ven atraídos sexualmente por la graciosa figura del joven, igualmente, habría una ligera connotación homoerótica por parte de las jóvenes, quienes estarían suspirado, sin imaginarlo, por una "mujer”. Sin duda, la androginia cobra aquí un espacio notable, dado que el binomio "Manolito-María" forja una contradicción detestable, pero profundamente inquietante.

Ahora bien, en cuanto al tópico homoerótico, "Manolito el pisaverde" proporciona una inesperada veta, no sólo por referir el tema del travestimiento, sino por presentar un claro flirteo homosexual en su primera parte. De este modo, si el portar indumentarias del género "opuesto" es un ardid bastante inusual, pecaminoso e inmoral para la cosmovisión de su tiempo, el proponer un acercamiento homoerótico parece, en verdad, una circunstancia inverosímil ¿cómo, en tales condiciones histórico-culturales, sería posible evidenciar el más descarado deseo por sujetos "del mismo sexo"? ¿Acaso no representa esta situación un arriesgado coqueteo con lo abyecto y, en buena medida, una razón de peso para la censura? Por razones ceñidas a la maestría narrativa de Rodríguez Galván, esto último no sucede. Tanto el travestimiento como el flirteo homosexual quedan en una circunstancia inusitada dada la trayectoria del discurso y diégesis del cuento. Esta última permite la comprensión cabal de estos dos acontecimientos transgresores como una mera estrategia narrativa, pero el hecho, aunque resuelto, queda latente y los lectores observan un cortejo entre varones, acaecido después de la entrada triunfal de Manolito en la fiesta y en el texto:

- Vamos a hablar con Manolito.

-Vamos - Gritaron todos, y se dirigieron adonde estaba el infeliz muchacho, quien vio venir la nube con la resolución del infeliz negro que recibe la pesadísima carga que el bárbaro de su amo le echa en los hombros.

— ¿Cómo va don Agapito Cabriolas y Bizcochea? —díjole uno poniéndole en el hombro la mano. 
—Vístase usted de mujer — dijo otro—, y por vida mía que nos casamos mañana.

— ¡Cuántos te envidiarían una muchacha tan linda!

—Por las pezuñas de Satanás, que me dan ganas de arrancarle ese bigote que está deshonrando — dijo un militar alto y grueso, y al mismo tiempo llevó su mano al rostro de Manuel.

Los rasgos femeninos destacados por el narrador al respecto de la figura de Manolito producen en los asistentes masculinos un profundo deseo. Si bien se trata de un joven al que, dadas las razones obvias del sistema de sexualidad imperante, no deberían acercarse por motivos eróticos, los varones de la fiesta irremediablemente son atraídos por la presencia de Manolito. De este modo, Rodríguez Galván crea un espacio lúdico muy sugerente: los lectores saben, al final del texto, que el flirteo - aun con apariencia de homoerótico- es sólo un pasaje humorístico del cuento y no hay una preocupación mayor al percatarse del intento de seducción ejercido hacia Manolito — a final de cuentas, se trata de una "mujer" y el posible ataque al sistema "heterosexual" queda como una simple broma-; sin embargo, desde otra perspectiva esta situación es un verdadero hallazgo: los acosadores de Manolito no saben del travestimiento de María y, sin pudor, lanzan sobre el personaje una auténtica arenga de deseo "homosexual". ${ }^{154}$ La cercanía con la niñez representada por el candor de Manolito, su cuerpo afeminado y el excesivo arreglo son, sin duda, los elementos que crean la proclividad hacia la bella imagen del personaje. Estos elementos instauran una aparente "masculinidad disminuida", cuya cercanía con el ámbito de lo femenino vulnera la normatividad sexual y permite, de forma directa, el acercamiento por parte de los acosadores de Manolito hacia éste; no obstante, estos proponen, para concretar aun más el afeminamiento

\footnotetext{
${ }^{154}$ Esta manifestación está anclada en una larga tradición homoerótica cuyo antecedente más famoso y reiterado es el modelo griego.
} 
del personaje, arrebatarle los elementos que son considerados como parte sustancial de la masculinidad del mismo: la vestimenta y el bigote. Sin proponérselo, el narrador articula un discurso centrado enteramente en el carácter construccionista del género, puesto que se busca eliminar del correspondiente a Manolito aquellas características cercanas a lo masculino. Sin esta barrera -y extrapolando, claro está, la diégesis del cuento- podría llevarse a buen término algún tipo de encuentro sexual entre el protagonista y sus acosadores: liberado Manolito ya de cualquier impertinente elemento masculino, se nulificaría el carácter "sodomita" o "invertido" de dicho suceso.

No puede obviarse en este análisis el enorme peso del sistema de deseo mediterráneo -señalado ya en el primer capítulo del presente trabajo-, cuyo principio regidor marca una separación determinante y clara entre el "sujeto activo" y el "sujeto pasivo" de la relación homosexual. Así, con base en este paradigma, los acosadores de Manolito buscan "femenizar" a éste con el objetivo de no ver menoscabada su masculinidad: aquellos no tendrían quebrantada su representación sexo-genérica por ocupar el papel de activo, mientras que el joven, por el contrario, ocuparía el rol pasivo y su prestigio estaría absolutamente acabado. La respuesta de Manolito corrobora esta aseveración cuando, en un arranque de furia por el tono de los piropos hacia él dirigidos, asume una actitud totalmente viril:

—Antes me arrancará usted el corazón —dijo éste [Manolito] levantándose. Y al mismo tiempo tomó una mano del atrevido militar, y tirándole de ella le decía一: Sígame usted, no faltarán dos pistolas.

Nuestro hombre, sorprendido a tales expresiones, quedó estupefacto e indeciso.

—Si tienes miedo —dijo uno-, iré yo.

- Y yo.

$-\mathrm{Y}$ уо.

$-Y$ yo. 
—Para todos habrá —replicó Manuel—, si tienen paciencia y quieren venir uno tras otro. ${ }^{155}$

Cuando María asume el género masculino hace uso no sólo de la vestimenta, sino de una serie de modales que le permiten afirmarse como tal. En este caso, la respuesta dada a sus acosadores corresponde a la perfección con un modelo de virilidad: evitar a toda costa una posible ofensa a su "hombría" y, por ende, cauterizar cualquier daño al estatuto sexual. Una situación contraria a la anterior colocaría a Manolito en un sito pleno de ambigüedades -las cuales son advertidas por los asistentes de la fiesta y el flirteo homoerótico sólo es el colofón de dicho desliz-, al respecto Adriana Fuentes Ponce menciona que "para ser considerado como perteneciente al conjunto de la no heterosexualidad, que es sinónimo de anormalidad, se requiere de la evidencia de tener un contacto sexo-sentimental con otro sujeto del mismo sexo". ${ }^{156}$ Así, con el fin de evitar la caída en un espacio poco prestigiado de las identidades sexo-genéricas, Manolito muestra un rostro agresivo con sus detractores. Más adelante, Fuentes acota lo siguiente: “en ocasiones, también se echa mano de la perspicacia y acusación de quienes se encuentran en rededor, y así se puede convertir a alguien en receptor de agresiones y distanciamientos". ${ }^{157}$ Esta circunstancia se observa claramente desde dos perspectivas: la primera está centrada sobre los acosadores de Manolito, quienes tratan de acorralarlo por sus "modales afectados"; 158 y la segunda recae sobre el protagonista, quien,

\footnotetext{
${ }^{155}$ Rodríguez Galván, p.34.

156 Adriana Fuentes Ponce, "¿Acaso se puede tapar el sol con un dedo? La violencia como herramienta de estabilidad social" en Mauricio List Reyez y otros, Florilegio de deseos. Nuevos enfoques, estudios y escenarios de la disidencia sexual y genérica (México: Eón/ BUAP, 2010), p. 229.

157 Loc. cit.

${ }^{158} \mathrm{El}$ acoso engloba, a su vez, un doble juego. Como se dijo en páginas anteriores, el joven pisaverde es visto de tal modo que puede satisfacer los deseos eróticos de mujeres y varones asistentes a la fiesta. Estos últimos practican la violencia a modo de fustigar al personaje por la "masculinidad disminuida" que presenta, pero se trata de un arma de doble filo en la cual ellos estarían atraídos por un individuo de su mismo sexo biológico.
} 
como respuesta a los ataques sufridos, esgrime una "descarga" de virilidad. Cuando Manolito responde al personaje que intenta arrancarle el bigote con la frase "antes me arrancaría usted el corazón”, plantea un revés al insulto padecido y, obviamente, condena cualquier tipo de agravio al sistema de sexualidad dominante. De este modo, el joven sólo accedería a los deseos de los otros si pereciera, para esto plantea un reto a todos aquellos que arrojaron sus ofensas. Claro está el ardid de género inscrito detrás del diálogo: antes de perder la "hombría", los personajes prefieren la muerte. Un caso muy similar a esta situación, aparece en el cuento "El matadero" (1838-1840) del argentino Esteban Echeverría; el protagonista de este texto, un joven y hermoso unitario, prefiere morir antes que ser "deshonrado" por los federales, quienes intentan violarlo con una mazorca para demostrar la "hombría" de estos y flaqueza de aquél. ${ }^{159}$ Como puede observarse, esta situación acentúa la importancia del sistema de deseo mediterráneo en América Latina: tanto el personaje travestido de "Manolito el pisaverde" como el muchacho unitario de "El matadero" demuestran fiereza y claman por su muerte antes que aceptar la destrucción de su prestigio de género mediante la “sodomización”; ${ }^{160}$ lo mismo ocurre con sus respectivos detractores: los relajados asistentes al baile de Teodora en la Ciudad de México y los acelerados federales del rastro a las afueras de Buenos Aires buscan menoscabar la "reputación" de sus respectivos contendientes -sin duda, Manolito es un verdadero contrincante en asuntos amorosos dado que resulta

\footnotetext{
${ }^{159}$ Bazán en su ya citada Historia de la homosexualidad en la Argentina menciona al respecto de este cuento lo siguiente: "era unitario el muchacho del que nunca sabremos el nombre. No usaba divisa punzó ni luto por la madrina del matadero, doña Encarnación Ezcurra. Por una terrible fatalidad pasó frente al Matadero de la Convalecencia o el Alto, fue capturado por los federales que allí trabajaban y llevado a la casilla interior. Los desvistieron e intentaron violarlo. El muchacho, ya atado y desnudo, a punto de ser desflorado, 'reventó de rabia'. La sangre le brotó a borbollones de la nariz y de la boca, y murió. Así queda fundada la literatura argentina; uniendo homosexualidad con violencia, honor con virginidad anal y sodomía con federales". Bazán, p. 62.

${ }^{160}$ Claro está que la muerte o su deseo es un elemento imprescindible de la narrativa perteneciente al romanticismo; no obstante, la causa
} 
demasiado atractivo para las jóvenes y esto engendra una profunda envidia y odio en los personajes masculinos- con el fin de "feminizarlos" mediante la obligación de adquirir un rol pasivo en una posible relación homosexual.

A su vez, hay otra coincidencia muy evidente en los dos cuentos mencionados, y está referida a la imagen de sus protagonistas. Con el mismo afán que el narrador de "Manolito el pisaverde" presenta al joven petimetre, el relator de "El matadero" hace lo suyo con la descripción de su almibarado unitario: "era éste un joven como de veinticinco años de gallarda y bien apuesta persona". ${ }^{161}$ Si bien es cierto que la representación casi mujeril de Manolito se debe a la supuesta relación natural con el sexo de María y, a su vez, el aire afeminado del unitario surge de la contraposición de éste con sus feroces enemigos federales, no cabe duda que en ambos textos $-\mathrm{y}$, sobre todo, en el de Rodríguez Galván- ocurre una asimilación del hombre acicalado con el "invertido sexual" del siglo XIX. Al respecto, Chavez menciona la clara relación entre este sujeto afeminado y el "homosexual" de la centuria pasada; no obstante, como el mismo autor acota, no se puede aterrizar una evidencia certera en el plano sexual, sino sólo un acercamiento a la representación de lo femenino: 162 "por medio de una conducta bizarra para su género, a través de una preocupación desmedida por la propia imagen en términos de vestido, peluquería, cosméticos, zapatos, así como por el gusto por asuntos mundanos pero improductivos, el baile, la fiesta, la seducción... la lectura". 163

\footnotetext{
${ }^{161}$ Rodríguez Galván, p. 35.

${ }^{162}$ En el capítulo anterior, se mencionó ya cómo el trabajo de José Ricardo Chaves aquí anotado hace una lista de este tipo de personajes en la narrativa mexicana; mas cabe recordar a Agustín, un personaje memorable de la novela Martín Rivas (1862) del chileno Alberto Blest Gana. Agustín es hijo es descrito con rasgos muy similares a los de Recordar aquí lo que Chaves dice sobre los hombres "disminuidos", relacionarlo con Monsiváis y otros para traer a colación la necesidad del "hombre" como entidad fundacional de la sociedad mexicana, en particular, y latinoamericana, en general.

${ }^{163}$ Chaves, "Afeminados, hombrecitos y lagartijos. Narrativa mexicana del siglo XIX", p. 73.
} 
De vuelta a "Manolito el pisaverde", es preciso acotar otra escena de un fuerte contenido homoerótico -aunque sustancialmente menor al diálogo entre el protagonista y sus acosadores durante la fiesta de Teodora-. Ésta se trata del momento en el cual Manolito se acerca a Jacinto Almaraz en un paraje de San Ángel para reclamarle su abandono e infidelidad. Desde la perspectiva del lector, en realidad es el momento climático en el cual se encontrarían María y Jacinto, pero desde la visión que podría tener el resto de los personajes se trata de una acalorada discusión entre dos hombres: "en esta situación triste y penosa estaba [Jacinto], cuando sintió una pesada mano que sobre su hombro caía, y una voz ronca y casi apagada que decía: -A usted buscaba-. Volvió la vista el joven y se encontró con un hombre envuelto en una capa [Manolito], y que, como un fantasma horrendo, permanecía junto de él sin moverse". ${ }^{164}$ A partir de este momento, se desarrolla una rebatinga entre ambos personajes y Jacinto desenmascara con crueldad a María, pero ésta aún está enfundada en Manolito y la escena denota una especie de flirteo entre los dos jóvenes, ${ }^{165}$ cuyo descubrimiento es inminente ante la cercanía de la gente que, durante la fiesta de la noche anterior, había organizado la salida a San Ángel para continuar la celebración por el matrimonio entre Teodora y Jacinto:

— ¡Jacinto! ¡Jacinto!, vámonos de aquí: todo te lo perdono con tal de que me vuelvas tu amor, con tal de que te arrepientas de tu crimen...

\footnotetext{
164 Rodríguez Galván, p. 36.

165 Sobre el mismo pasaje, Chaves menciona lo siguiente: "Esta revelación de la identidad femenina de Manolito va acompañada de cierta solemnidad, con paisaje trágico y romántico, aunque al mismo tiempo se carga de ridículo, pues lo que visualmente se da al lector es el encuentro airado de dos hombres que se hablan de amor y de odio. [...] En alguna medida el marido descubierto es consciente de que a nivel de apariencias la escena de amor que su primera mujer le ha montado se ve como la de un hombre hacia otro hombre." Chaves, pp. 70-71.
} 
— ¡Maldita sea mi suerte!... ¿No escuchas esos gritos?... ¿No miras aquellas luces?... Ya vienen, ya vienen...

—Huyamos, Jacinto mío, mi esposo, huyamos...

—Ya vienen, ya se acercan, ya están aquí... ¡si me encuentra contigo!... ¡Satanás te confunda!...

Las luces se iban acercando. Los concurrentes habían extrañado a Almaraz, y venían algunos a buscarle. María se hincó, abrazó las rodillas de su esposo y exclamó llena de afán:

—No me separo de ti; yo te amor; que vengan, yo gritaré que eres mi esposo, yo pediré tu perdón... ¡Pero separarme!...

—Es preciso —dijo Almaraz agitando y poniéndose pálido y sudoroso-; es preciso, no hay otro remedio: encomiéndate a Dios... ¡Salva tu alma!

Y diciendo así arrastró a María hasta el borde del precipicio.

— ¡Perdón!, ¡perdón! —exclamaba la joven—; no me des la muerte, no me asesines...

Pero su voz se apagó y sólo se oyeron algunos ayes y el golpe del cuerpo que se despedazaba contra las peñas... ${ }^{166}$

Antes de perder su honra por la bochornosa situación con Manolito y, en dado caso, confesar a sus conocidos la existencia de María, Jacinto decide arrojar a ésta al barranco; sin embargo, debido a un movimiento equivocado él también cae y ambos personajes perecen. Esta última parte de la diégesis corresponde a un clásico final del romanticismo y trae a colación otro cuento de Rodríguez Galván, "La hija del oidor”, en el cual la protagonista es asesinada por su propio padre ante el descubrimiento del embarazo e intento de huída de aquélla. Ambos textos están insertos, pues, en una brecha literaria cuyo eje temático sugiere un acontecimiento trágico como colofón de sus respectivas historias.

Como se ha visto, "Manolito el pisaverde" resulta un cuento verdaderamente revelador en cuanto a la representación homoerótica se refiere. No sólo aborda de forma 
directa el tema de la androginia y el travestimiento -los cuales, de modo independiente, serían bastante transgresores-, sino que plantea una auténtica escena de flirteo homosexual, en la cual pone en tela de juicio los principios fundacionales del dispositivo de la sexualidad mexicano. Otro cuento que hace lo suyo al respecto de las circunstancias mencionadas - pero publicado en una fecha muy posterior al texto de Rodríguez Galván- es "Aventura de carnaval" (1890-1895) de Amado Nervo. Este cuento provee una veta muy interesante para la investigación aquí realizada tanto por la presentación de un personaje masculino travestido como por la reveladora evidencia del deseo homoerótico en el mismo.

"Aventura de carnaval", a pesar de ser un texto breve, plantea una reflexión profunda sobre el tema de la identidad y, para lograr tal cometido, indaga en el uso de prendas del género opuesto. De este modo, la historia del cuento sintetiza la relación entre el narrador y su primo Carlos. El primero, al parecer, ha atravesado una desavenencia amorosa y, por tanto, arguye al segundo cómo ninguna mujer podrá ya despertar su interés; sin embargo, Carlos desea realizar una trampa su primo y le plantea lo siguiente: “¿Apostamos un almuerzo, que yo te daré si antes de ocho días no estás enamorado, y que tú me darás en caso contrario?"167 El narrador, en su afán de sostener sus afirmaciones, acepta tal propuesta y quedan de verse en un baile por la noche. En dicho evento, Carlos acude vestido de mujer y, sin que nadie lo perciba, seduce hábilmente a su primo. Éste se muestra desarmado ante el flirteo de la hermosa dama y bailan toda la noche como felices enamorados. Al final, el narrador solicita ver el rostro de la joven antes de que ésta parta, la sorpresa estriba en el descubrimiento de su primo Carlos oculto tras el nuevo revestimiento femenino.

${ }_{167}$ Amado Nervo, Obras completas, v. 1, p. 63. 
La anécdota entonces puede percibirse como simple pero jocosa, anclada en las escenas trilladas del humor mexicano, en las cuales aparece siempre un personaje travestido que produce las estridentes carcajadas del público; no obstante, el juego planteado por Nervo toca una de las fibras más íntimas e inapelables de la heteronormatividad: la "naturalidad" del género. Desde el inicio, el texto sumerge al lector en un mundo plagado de parafernalia: “El baile estaba en su apogeo. Innumerables máscaras cruzaban el salón en distintas direcciones, cuchicheando, hablando, riendo". ${ }^{168}$ Esta cita es reveladora no tanto por apelar al espacio lúdico de una fiesta de disfraces, sino por ser una sustanciosa alegoría en torno al tema de la identidad sexo-genérica, alegando, sobre todo, la posible "performatividad" de la misma.

En primer lugar, puede equipararse el espacio del baile citado por el narrador con el ámbito sociocultural en el cual se desarrolla un determinado individuo: ambos sitios poseen ciertas reglas conductuales cuyo seguimiento o evasión por parte de los invitados/sujetos conllevaría una representación de prestigio o marginación, respectivamente. En segundo término, las máscaras estarían en concordancia con los diversos roles ejecutados por estos invitados/sujetos, cuya caracterización es obligatoria para ingresar al espacio de la festividad; a final de cuentas, tanto el baile como la máscara respaldarían esta suerte de código conductual en un marco normativo.

Ahora bien, la "performatividad" señalada por este pasaje sirve de anclaje para la historia del cuento, dado que rotula a la investidura desde el punto alegórico en el cual estarían cruzados semánticamente la máscara y el rol social desempeñado por los invitados/sujetos. Si el disfraz adquirido en el baile posibilita el acceso a la fiesta y, de algún

\footnotetext{
168 Loc cit.
} 
modo, denota la actividad desarrollada por su portador durante la misma, el rol social podría concebirse en los mismos términos por efecto de la historia relatada. Así, parodiando los famosos versos de Villaurrutia, el cuerpo toma la forma de la investidura y, sin duda, "es el espacio frío que levanta entre los dos un muro, un cristal, un silencio" si se le toma desde el ángulo de la prohibición, pero, desde otro, funcionaría a modo de escape y vulneración de la normatividad. En otras palabras, la máscara/rol social, en un momento dado, aleja a los personajes del relato en cuanto a una posible relación erótica; no obstante, esta misma puede acercarlos intercambiando la barrera por el contacto: es impensable la relación erótica cuando ambos poseen un revestimiento masculino, aunque si alguno de ellos lo infringe, la posibilidad de acercamiento es efectiva. En este caso, el señalamiento de la "performatividad" es palpable en el texto por el advertimiento de la máscara y sus repercusiones en el sujeto portador, dado que lo somete a seguir una normatividad. Al respecto, Butler menciona que dicho concepto debe comprenderse "no como el acto mediante el cual el sujeto da vida a lo que nombre, sino, antes bien, como ese poder reiterativo del discurso para producir los fenómenos que regula e impone". ${ }^{169}$ La alegoría de la fiesta trae a colación esta circunstancia con base en la adquisición de un revestimiento de forma voluntaria: el invitado acude a dicho evento bajo la consigna de portar la máscara de su predilección. Sin embargo, en el caso del ámbito sociocultural, esta situación es impuesta: Carlos, el primo del narrador, debe seguir una identidad genérica masculina -la cual es respaldada con base en la lectura de los rasgos corporales de una diferencia sexual-, pero, con el objetivo de seducir a su primo y ganar la apuesta formulada al principio del cuento, deliberadamente asume una identidad correspondiente al género femenino. De este modo, la

169 Butler, Cuerpos que importan, p. 19. 
alegoría del baile con respecto al contexto sociocultural plantea el aspecto lúdico de ambos acontecimientos e informa al lector de la performatividad tanto desde la perspectiva de la imposición como de la subversión.

Una vez esbozadas algunas de las implicaciones de este pasaje inicial, y en línea con los sucesos del relato, debe mencionarse la forma en la cual el narrador articula un ferviente discurso en torno a su primo, que, sin duda, resulta paradójico con respecto al final del cuento:

Carlos era un muchacho muy guapo. Mediana, pero gentil estatura, oscuro y rizado pelo, negros ojos árabes, llenos de expresión y de fuego, poblada barba. Sus formas redondeadas y marmóreas ocultaban, bajo un cutis de mujer, un tejido de músculos de hierro, sus manos eran aristocráticas y llenas de hoyuelos; pie pequeño... Una galanura, en fin. En cuanto a lo moral, bromista, alegre siempre y, por lo demás, generoso y bueno. Donde él estaba reinaba la animación y el buen humor. ${ }^{170}$

La enumeración de los rasgos de Carlos resulta formidable con respecto al tema aquí trabajado. Al parecer, la galanura de este personaje tiene su origen en la carismática ambigüedad de su cuerpo que a momentos es profundamente masculino y, en otros, resulta comprometedoramente femenino. Además, esta descripción de Carlos es muy cercana a la de Manolito del cuento de Rodríguez Galván, lo cual alude, nuevamente, al deseado tema de la androginia y, por tanto, a la búsqueda de la belleza en los espacios intergenéricos y al inevitable magnetismo de los mismos. Y aunque la circunstancia del travestimiento en ambos cuentos es obvia, merece la pena recalcarla para establecer un puente de análisis en los dos textos: si los detractores de Manolito son seducidos por su incauta y noble belleza, el narrador de "Aventura de carnaval" es envuelto en la cadenciosa magia de su primo. Los dos

\footnotetext{
${ }^{170}$ Nervo, Obras completas, p. 63
} 
acontecimientos remarcan entonces el aspecto performativo de las identidades sexogenéricas y las múltiples facetas corporales, cuyos alcances no son percibidos debido a la misma materialidad del discurso normativo.

Pero, de vuelta a la descripción de Carlos, es preciso acotar el entusiasmo con el cual su primo lo observa. Sin duda, el hecho se traslada de una relación homosocial a un trance absolutamente homoerótico. Existe una línea de deseo entre ambos personajes que se esconde bajo el mismo argumento de la alegoría de la máscara antes mencionada. Esto último lo conoce cabalmente Carlos, quien no titubea en su travestimiento ni, mucho menos, en la capacidad de seducción que puede ejercer sobre su primo: antes de advertirlo con el traje femenino, el narrador, de algún modo, está ya seducido por la belleza sui géneris de Carlos, el cual, sabedor de este hecho, adivina los grandes alcances que tendría portando una indumentaria femenina cuando lanza el reto a su interlocutor. ${ }^{171}$ Así, durante el citado baile, el narrador es interpelado por una figura extraña y cautivadora:

— ¿Por qué estás tan solo? ¿Haces versos?— murmuró una voz melodiosa a mi oído. Una máscara vestida con un lujoso dominó negro se había sentado a mi lado.

—Pienso en el pasado— le contesté afectando buen humor.

Dos ojos negros que asomaban tras de aquel antifaz, negro también, se fijaban en los míos con rara insistencia. Un perfume suave y voluptuoso se escapaba del traje de aquella mujer. Yo me aturdía.

${ }^{171} \mathrm{Al}$ respecto de la descripción hecha por el narrador y la argucia seductora de Carlos, Chaves anota: "Obsérvese en esta descripción la estrategia androginizante, que mezcla elementos femeninos y masculinos: las formas redondeadas, el cutis de mujer y el pie pequeño, con la poblada barba y el tejido de músculos de hierro. Otros rasgos son bisexuales: estatura, cabellera, esos "negros ojos árabes" que lo seducirán a través del disfraz. De Cierta manera, este primo ya estaba seducido antes de la aventura de la fiesta, aunque sea sólo durante ese tiempo de excepción que es el carnaval cuando el deseo oculto se manifiesta en la superficie, matizado en este caso con la risa. El disfraz ha sido de esta manera el vehículo para hacer visible un deseo velado en tiempos de normalidad." Chaves, "Afeminados, hombrecitos y lagartijos. Narrativa mexicana del siglo XIX", p. 72. 
—Deja lo pasado y piensa más en el presente- me dijo con una voz llena de dulces inflexiones.

—Dices bien— le contesté maquinalmente. ${ }^{172}$

Cabe destacar en esta cita la presencia hechizante de los ojos de la joven con respecto a los "negros ojos árabes, llenos de expresión y de fuego" de Carlos. Hasta este punto, el lector desconoce quién está oculto detrás del antifaz; no obstante, el narrador está contando la historia de modo ulterior, es decir que conoce ya a la perfección los detalles de la misma y asocia, deliberada o involuntariamente, este puente entre la mujer del baile y su primo. Además, junto con los ojos, el perfume y la voz dulce de la joven ejercen un efecto de aturdimiento en el narrador. Esta alusión enclava a la perfección en el pasaje inicial: el travestimiento de Carlos justifica totalmente la perspectiva de la máscara y, por supuesto, el carácter performativo del género. El cuerpo de ambos personajes está marcado por una lectura sexuada y propone entonces una sujeción a un determinado código social -como la masculinidad, en este caso- pero la transformación de Carlos corrobora el agotamiento de la supuesta naturalidad de esta premisa.

Más adelante, el narrador declara un momento importante no desde la perspectiva diegética, sino desde la actitud subversiva -con respecto al régimen heteronormativoproporcionada por el texto. Después del diálogo inicial entre el narrador y Carlos travestido, ocurre un momento de silencio. El primero menciona que, durante este tránsito, reflexionó sobre la aparente peligrosidad de algunas mujeres, "sobre todo cuando las rodea el atractivo misterioso de lo desconocido", ${ }^{173}$ y acota: "mi compañera dejó oir un suspiro ahogado". ${ }^{174}$ Sin duda, el narrador sabe ya el furtivo efecto de esta fascinante mujer y lo asocia con un

\footnotetext{
${ }^{172}$ Nervo, “Aventura de carnaval”, p. 64.

${ }^{173}$ Loc. cit..

${ }^{174}$ Loc. cit.
} 
posible grado de maldad, muy al estilo de la femme fatale finisecular. Carlos, en cambio, está haciendo un alto en el camino y, con la posibilidad de caer en la sobre interpretación, ¿puede decirse que reflexionaría al respecto de la condición masculina de ambos y la coyuntura del disfraz? La respuesta es ambigua, pero está connotada por el cuento.

Una vez superado este trance, la mujer invita a bailar al narrador y el proceso de la seducción es llevado a un término excelente: “Aquello no era bailar. Aquello era un torbellino de seres. Su pequeña mano enguantada oprimía la mía con fuerza extraordinaria. Sus negras miradas se fijaban en mis ojos... y me quemaban... ¡Aquello me hacía daño! Quise fortalecerme para resistir, y evoqué los tristes recuerdos de mi último amor. Era en vano. Aquella mujer me fascinaba. Yo me estremecía a cada paso". ${ }^{175} \mathrm{El}$ baile vulnera las barreras entre ambos y el contacto corporal aparece más cercano; nuevamente, la presencia de los ojos es brillante y son el arma más efectiva de Carlos para lograr su cometido. Éste es el punto en el cual la apuesta está perdida por parte del narrador, quien acepta ya el olvido de su último amor y la fascinación brutal ejercida por parte de Carlos. Al igual que en la cita correspondiente a "Manolito el pisaverde" -en la cual los detractores del joven protagonista resultan sus más fervientes adoradores- es en esta parte de "Aventura de carnaval" donde aparece con mayor fervor el contacto homoerótico entre los personajes al grado que el narrador declara la transformación de ambos en un "torbellino de seres". No obstante, a pesar de la profunda atracción ejercida por esta mujer durante el baile, el narrador no escatima imaginación y observa en ella un dejo de maldad. Es curioso observar cómo durante esta etapa del relato hay una mención constante al peligro y al posible daño causado por la mirada de la seductora mujer, circunstancia reiterada renglones más adelante, cuando ambos

\footnotetext{
${ }^{175}$ Loc. cit.
} 
personajes suspenden el mencionado torbellino y comienzan a discurrir en torno a la peculiaridad de los ojos de la joven:

— ¿Estás malo? - me dijo entonces con voz apasionada.

—No... es que el baile me cansa.

-Daremos vueltas.

-Como gustes...

-Parece que no estás contento...

—Contigo no se puede estar contento

—¿Por qué?

-Porque tus miradas hacen daño.

La máscara dejo oír una carcajada.

—No te rías. Hablo con formalidad. Tienes sobre mí una terrible influencia...

- ¿De veras?

${ }$ ¡Oh, te lo juro!

- No vayas a enamorarte...

-No sería difícil... ${ }^{176}$

Resulta un tanto paradójica esta cita en cuanto a la contraposición de la mirada como objeto de culto y, a la vez, como dañina herramienta. Sin duda, esta circunstancia puede extraporlarse a un plano diegético mayor, en el cual la paradoja es concretada por el bochornoso final. Este recurso metonímico es muy atractivo, ya que delata el exacerbado deseo del narrador, en general, por el cuerpo de la mujer $-\mathrm{y}$, por ende, de Carlos- y los posibles efectos nocivos de dicha relación en una consumación efectiva. Al mismo tiempo, la frase referida a la máscara en la cita anterior es bastante emblemática, ya que reitera la

\footnotetext{
176 Nervo, “Aventura de carnaval”, p. 64.
} 
visión de la máscara y su relación con la teatralidad. En este caso, hay una clara prosopopeya la cual enmarca un rasgo de festividad como lo es la carcajada: inmerso en el ambiente de la carnavalización el narrador pondera el carácter lúdico del personaje y el grado de vitalidad o humanización que puede brindar el disfraz. Cabe mencionar aquí una división entre lo que podría representar la máscara -en cuanto al revestimiento del individuo- y el cuerpo del propio sujeto, lo que genera irremediablemente una cuestión ¿la fijación del narrador es por el género de la persona con la cual baila o por la corporalidad de la misma? Esta pregunta abre un debate muy amplio cuya repercusión se halla situada en los principios que fundamentan el género.

Poco antes del final del cuento, el narrador exige ver el rostro de la mujer que tanto lo ha hipnotizado a lo largo del baile, lo cual genera una pequeña discusión entre ambos personajes; no obstante, Carlos cede y muestra su cara al narrador, quien relata lo siguiente: "Yo di un grito de asombro. ¡Aquel rostro, varonil y barbudo, era el de Carlos! Si en aquel momento hubiera tenido un arma cualquiera, habría matado a mi primo, que se reía a carcajadas". ${ }^{177} \mathrm{Al}$ igual que en "Manolito el pisaverde", el narrador de "Aventura de Carnaval", una vez marcada la denotación homoerótica, apuesta por la muerte de su primo ante el entredicho de su identidad sexual y, por ende, una posible pérdida de masculinidad; sin embargo, en el caso del cuento de Nervo, no hay una justificación tan sólida para señalar el homicidio como alternativa. Si se toma en cuenta la importancia del sistema de deseo mediterráneo, el único personaje cuya masculinidad ha trastrocado es Carlos y no el narrador, ya que a diferencia de "Manolito el pisaverde", en el cual el protagonista apela por demostrar su hombría mediante el reto a muerte ante una posible feminización - ¿sodomización?- por

\footnotetext{
177 Nervo, “Aventura de carnaval”, p. 64.
} 
parte de sus detractores, el narrador de "Aventura de carnaval" continúa en su misma identidad sexo-genérica y, además, su estado de deseo, si bien está totalmente influido por la imagen de su primo, al momento del baile está dirigido hacia una mujer, sin importar aquí las características de la diferencia sexual de la persona portadora de este género durante el tránsito señalado. Por tanto, este deseo del narrador por asesinar a Carlos está más cercano al hecho de la burla y, obviamente, al de la transgresión creada por el primo mediante su travestimiento. Esto suscita recordar cómo cada sujeto incrustado dentro del dispositivo heteronormativo es imbuido con la idea de rechazar y mostrarse defensivo ante cualquier atentado pretendido contra éste. Aquí surge, de forma muy subrepticia pero profundamente devastadora, un principio de violencia intrínseco a la hegemonía del estatuto sexo-genérico. Lamentablemente, el narrador del cuento tiene un filtro cultural bastante bien delimitado e inamovible y, aunque presenta un evidente deseo por la figura de su primo, éste sólo se queda en el espacio de lo imaginario. Por ello, cuando descubre la celada no tiene más remedio que repudiarla, a pesar de haber disfrutado tanto al lado de la seductora mujer. No hay espacio aún para aceptar la disidencia y, mucho menos, el propio deseo homoerótico. Ante esto, la afrenta de Carlos produce un escozor más irritante, ya que pone en tela de juicio la naturalidad del género, los paradigmas del deseo y genera un estupendo boicot al soterramiento del deseo inescrutable del narrador. Cabe destacar aquí también la risa de Carlos una vez descubierto su ardid, lo cual remite al lector a la ganancia de la apuesta y conlleva a pensar si este personaje se mofaba de la fragilidad de las convicciones de su primo, de la complacencia ante el descubrimiento del inevitable atractivo ejercido -sin importar el género utilizado-por su propio cuerpo o, sin duda, de ambas circunstancias.

El último de los cuentos analizados en este apartado posee una diégesis muy parecida a la de los dos anteriores. "La excursionista" de Federico Gamboa, incluido en el volumen 
Del natural (1889), propone una visión divertida y extravagante sobre el homoerotismo. Al igual que el cuento de Rodríguez Galván y Nervo, el de Gamboa hace uso también de un personaje travestido y, de la misma manera, este recurso es usado para otros fines, muy diferentes a una posible sexualidad disidente. Sin embargo, lo más importante de la historia del texto para este trabajo subyace en poner en tela de juicio los preceptos de una identidad de género "estable".

Del mismo modo que en "Manolito el pisaverde", "La excursionista" tiene una historia cuyo inicio no sugiere claramente la presencia del personaje travestido y sólo da un par de guiños que suponen una circunstancia extraña con respecto al protagonista, Eva Blackhill. El cuento relata una aventura de viaje inicia por un grupo de estadounidenses en el El Paso, quienes deciden, a través de un agente de viajes, hacer un recorrido hasta la Ciudad de México con el objetivo de gozar de sus prerrogativas, paseos, clima y, hasta cierto punto, observar la factibilidad de inversión en algún determinado negocio. Este grupo es bastante uniforme y está conformado, en su mayoría, por personajes pertenecientes a una clase media, entre quienes se forma una amistad a lo largo del periplo. No obstante, Eva se integra casi al final a este grupo, justo antes de que inicie el viaje, y nadie conoce sobre su origen ni intenciones. El contingente de viajeros decide realizar un acercamiento a la misma, pero ésta cortésmente los evade.

A lo largo de la narración que tiene como escenario los vagones del tren en el cual realizan el viaje los personajes desde El Paso hasta la Ciudad de México, el narrador heterodiegético lanza ciertos guiños con el fin de brindar el perfil poco convencional sobre 
Eva, de quien señala, sobre todo, su ropa que la cubre por completo, una corporalidad vasta, ${ }^{178}$ su carácter huraño ${ }^{179} \mathrm{y}$, lo que más causa estupor y enojo entre las señoras, sus largas permanencias durante la mañana en el gabinete reservado para las necesidades de las mujeres. ${ }^{180}$

Con estos rasgos generales, pero definitorios, se va construyendo en las primeras páginas la personalidad de Eva. Cabe resaltar, por parte del narrador, una intención clara que resalta lo tradicional sobre lo heterodoxo. Así, Eva es señalada como una mujer "diferente", en comparación con el resto de las "señoras", y el tren se transforma, simbólicamente, en un microuniverso social profundamente sancionador y vigilante de todo aquello con suficiente capacidad para amenazar las "buenas costumbres".

Las "diferencias" del personaje constituyen la principal apuesta por parte de la historia, ya que mediante el entramado producido por los guiños se crea un suspenso cuyo efecto en el lector es el deseo de conocer hasta dónde llegará Eva. Obviamente, los señalamientos hacia las rupturas planteadas por la protagonista advierten una cercanía con el travestimiento, ya que es de notar cómo el narrador coloca una cuestión del ámbito

\footnotetext{
178 "Un largo cubrepolvo seguía los pronunciados contornos de su cuerpo, que parecía excesivamente desarrollado, sobre todo en cuanto a la estatura, sin poder asegurarse qué cara tendría. El velito color de rosa que llevaba, se la ocultaba completamente. Sus pies, que contra la costumbre reinante, procuraba enseñar lo menos posible, no eran nada pequeños". Federico Gamboa, "La excursionista", en Del natural. Esbozos contemporáneos (Guatemala: Tipografía "LaUnión”, 1889), p. 59.

179 "Comenzaron las conversaciones a generalizarse entre todas las señoras y sólo Miss Eva se conservaba aislada en su asiento y como dormitando". Gamboa, p. 60.

180 "El despertar del día siguiente fue temprano. Los caballeros cruzaban el coche en dirección al lavabo con la ropa sobre el brazo y los tirantes caídos. En el tocador de las señoras había su alarma. Ocupado por Miss Eva, cuya tardanza en abrir era inexplicable, se impacientaban las demás de ese pudor exagerado. Era el colmo, ocultarse de ellas como si fueran varones! Generalmente, dos o tres se asean al mismo tiempo, hablando poco y sin fijarse en los hábitos de la vecina. Qué más da que las personas del mismo sexo se descubran mutas y ligeras imperfecciones, si los trajes las hacen desaparecer completamente? (sic) Salió Miss Eva al fin vestida siempre con el enorme guardapolvo, con su sombrerito y con su espeso velo. Saludó disculpándose de su tardanza y luciendo una voz tan fuerte, como la del mejor contralto". Gamboa, p. 61.
} 
"femenino" comparada con una supuesta corporalidad "masculina". La visión binaria del género queda bien demarcada el texto con esta dualidad, y amenaza además con ofrecer al lector un verdadero banquete humorístico cuando se descubra la "verdadera identidad" de Eva.

Una vez que todos los personajes llegan a la Ciudad de México se establecen en el hotel seleccionado por el agente de viajes; sin embargo, Eva prefiere mantenerse nuevamente al margen del grupo y busca un lugar en el cual estar en soledad. Y casi al mismo tiempo que este acontecimiento ocurre, un joven perteneciente a la clase media mexicana, Fernando, observa de lejos a la protagonista y comienza a manifestar por ella cierto enamoramiento. A partir de este momento, el narrador crea en "La excursionista" una suerte de "estira y afloje" entre los dos personajes: Fernando a cada momento busca una acercamiento definitivo podría decirse que sexual- con Eva, mientras que ésta en un principio ni siquiera desea recibirlo. Esta parte, sin duda, es la más extensa del cuento; además, por obvias razones relacionadas con el suspenso, está focalizada en Fernando y en el grupo de viajares estadounidenses, mientras que Eva sólo aparece para reforzar la idea de su "diferencia", desapego o excentricidad con respecto tanto a su paisanos como con su joven enamorado.

Las técnicas seguidas por Fernando para "conquistar" al objeto de su deseo son variadas, pero sigue una trayectoria planteada desde el principio, tal como se lo comenta a Gabriel, su amigo: "Le traduciría sus cartas a él, una diaria por lo menos, y a fuerza de flores, misivas e invitaciones, se rendiría muy pronto". No obstante, la meta imaginada no llega a buen término y pasadas varias semanas de incesante acoso por parte de Fernando, Eva ni siquiera se toma la fatiga de responder las cartas. Una vez que el joven enamorado desiste un tanto de su contienda, sucede lo inesperado: Eva le ha enviado una carta para tener una cita. La breve charla se lleva a cabo en la casa de Eva y ella accede a verlo con cierta frecuencia. 
El lector advierte que dicha aceptación por parte de la protagonista no es más que un ardid para obtener dinero y, en un principio, Fernando accede sin dificultades a proporcionárselo. Posteriormente, Eva decide salir de viaje con el objetivo de "vigilar" ciertos negocios en el interior del país, ante esto el joven enamorado le otorga una buena suma para sus gastos. Pasados los días, Eva no se comunica con Fernando, hasta que éste decide visitarla y le recrimina el abandono y la explotación económica a la cual fue sometido por ella. Eva, por supuesto, intenta librarse de los reproches y acepta acudir con él un prestigiado restaurante con el fin de compartir una romántica velada. Dicho encuentro se ve sacudido por la influencia del alcohol en Fernando, quien ya con cierta valentía intenta robar un beso a Eva, ésta lo evade con fuerza y se arma una pequeña contienda entre ambos que los conduce a la cárcel. Una vez en dicho sitio, Eva, claro está, es conducida al espacio destinado a las mujeres y, nuevamente, ocurre un escándalo ahí: se descubre que la viajera estadounidense era en realidad un "filibustero tejano, que personalmente quiso enterarse de cómo andaba la pública opinión respecto a sus congéneres y que adoptó un disfraz femenino para no ser reconocido en la empresa! (sic)." ${ }^{\prime 181}$

La anécdota, como se advierte, es sencilla, probablemente los más de cien años establecidos entre la publicación del cuento y la realización del presente trabajo hagan que, desde el principio, la "diferencia" de Eva sea clara. Igualmente, esta distancia temporal puede arrojar cierta inocencia sobre la anécdota. Sin embargo, para el tiempo en el cual fue redactado y sacado a la luz el texto, el hecho resultaba más que extraño y perturbador. No hay duda de que el travestimiento era, para la primera década del porfiriato, un hecho estremecedor de la conciencia mexicana. Para estos años, como se mencionó ya en el primer

\footnotetext{
181 Gamboa, p. 109.
} 
capítulo de este trabajo, ocurrió en México un supuesto "carácter científico", llegado al país a través de los positivistas, cuya característica consistía en reedificar la visión del hombre sobre la naturaleza y la sociedad con base en él. La conducta sexual tuvo un espacio privilegiado en dichos estudios y todas aquellas desviaciones tomadas por la Iglesia como pecados fueron denominados delitos:

Biologizar las diferencias para justificar la desigualdad y la represión es una práctica común de la ciencia y de la medicina del siglo XIX (y de la de ahora). Lo que la ciencia y la medicina hacen con la sexualidad no convencional, lo hacen también con los negros, los criminales y con los anarquistas, con los pueblos colonizados y con las mujeres. Desde el siglo XIX hasta la Segunda Guerra Mundial (gracias a la ciencia y a la medicina), el ser "normal" será de origen europeo, blanco, heterosexual y varón. $^{182}$

Con base en esto, a lo largo del cuento es observada una perspectiva más científica que religiosa sobre el travestimiento de Eva. Así, desde el principio se plantea al cuerpo con características biológicas cuyas repercusiones en la percepción del género son evidentes: las manos, la voz, la estatura y los pies de la protagonista no corresponden con una visión "familiar" sobre lo femenino, pero, hasta cierto punto, se acepta. Lo que resulta una “infracción" más grave para el resto de los pasajeros durante su periplo en el tren es la conducta "excéntrica" de la protagonista: "Abrióse paso a los comentarios y a las suposiciones. ¿Sería......? y una ráfaga de pudor avivó los hermosos colores de las señoras. Era preciso averiguarlo y si las sospechas resultaban ciertas, poner inmediatamente el remedio. Buena es la república y buena la liberta individual, pero con taxativas, sin

182 Óscar Guasch. La crisis de la heterosexualidad (Barcelona: Laertes, 2000), p. 71. 
abusar". ${ }^{183}$ Esta postura manifestada por el narrador sobre el resto de los pasajeros es muy importante: se aclara el principio de la libertad, pero una libertad con límites. Por tanto, no puede realizarse aquello considerado "al margen" de un código de conducta bien definido.

La infracción representada entonces por Eva pone en jaque a toda la sociedad del tren y, posteriormente, a la correspondiente en la Ciudad de México. Cabe destacar un punto importante durante la narración del viaje, en cual el agente advierte que Eva usa pantalones debajo de su enorme guardapolvo: "Para concluir les comunicó una observación que acabó de exaltarlos, de enrojecerlos. La víspera, mientras Miss Eva dormitaba descuidadamente, había podido ver por debajo del vestido la extremidad de unos pantalones de hombres. Sí señor, de hombre, les gritaba al ver que movían la cabeza en señal de duda". ${ }^{184} \mathrm{La}$ institucionalización del binomio genérico tomando como base a una heterosexualidad normativa genera un grave conflicto al observar una mezcla de vestimentas en la protagonista: para el narrador y para los personajes involucrados Eva se convierte en un ser casi monstruoso, sobre todo si se toma en cuenta la descripción dada por el primero al respecto de la enorme y magnífica corporalidad de la protagonista.

Posteriormente, en la Ciudad de México, se da todo un alegato de "buenas costumbres" sobre la sexualidad. Como ya se dijo, Fernando se enamora de Eva y ésta lo rechaza continuamente. Así, queda muy claro cómo el protagonista, a pesar de su travestimiento mantiene una conducta sexual hetero. Esto sucede también a bordo del tren, cuando una emisaria es enviada por el resto de los viajeros con el objetivo de incorporar a Eva a su comunidad, de este modo el primer personaje cuenta lo siguiente: "Me besaba

\footnotetext{
183 Gamboa, pp. 61-62.

${ }^{184}$ Idem., pp. 63-64.
} 
mucho, pero sin retirar su velo, y ni un instante dejó de acariciarme las manos". ${ }^{185}$ Esto corrobora la tesis comentada al inicio de este análisis sobre el proceso de travestimiento como un recurso para ocultarse de los demás y realizar ciertas acciones que, con la vestimenta "tradicional", habrían resultado impensables.

El filibustero, pues, articula una identidad de género con base en la vestimenta y los modales en un espacio público, pero continúa con una sexualidad ortodoxa. Además, esto se vincula con una cuestión de maldad, tal como lo señala Chaves en la siguiente cita:

Desde antaño sabemos de las posibilidades diabólicas del disfraz, su capacidad de encubrimiento y engaño, sus vinculaciones con la mentira. A finales del siglo XVIII, en plena insurgencia romántica, algunos escritores usaron el disfraz como estrategia de seducción sexual y metafísica, por ejemplo en la literatura gótica y fantástica. Entonces el demonio asumió una androginia proteica, una capacidad pansexual que se cristalizó en formas y antifaces femeninos y masculinos, con tal de convencer al incauto y obtener su perdición. ${ }^{186}$

Claramente, las características del ser bandido y del ser invertido quedan establecidas en el personaje a través del lazo simbólico que las une en la cosmovisión mexicana de finales del XIX: la maldad.

Otro aspecto que debe resaltarse sobre el cuento, es el temor y rechazo rotundo hacia el deseo homoerótico. Eva desde un principio evidencia un absoluto desprecio hacia el flirteo por parte de Fernando y sólo accede cuando la situación económica se torna adversa, aunque esta "aceptación" no implica, para nada un contacto físico. El discurso imperante de la homofobia aparece aquí bien delineado; aunque más que homofobia, para ese tiempo habría

\footnotetext{
185 Gamboa, p. 65.

${ }^{186}$ Chaves, "Afeminados, hombrecitos y lagartijos", p. 67.
} 
sido más adecuado nombrarlo como un simple rechazo a la identidad del "invertido", para aquellos más cercanos a lo científico, o como un desprecio había la figura del "sodomita", para quienes todavía observan su sociedad bajo el amparo de las reglas eclesiásticas. Al respecto de esta cuestión, Daniel Borrillo plantea cómo la homofobia es una de las bases de la identidad masculina y, por tanto, la lógica seguida consiste en una declaración de odio hacia todos aquellos individuos que se acercan a la identidad femenina, como sería el caso de los personajes que viajan junto a Eva en el tren. Igualmente, el propio filibustero texano participa de ello, a pesar de su travestimiento: "el miedo a ser considerado 'maricón' constituye una fuerza mayor en la composición del papel masculino tradicional" ${ }^{187}$ Esto último queda bien claro con la escena correspondiente al restaurante, casi al final del cuento, en la cual Eva y Fernando se encuentran cenando:

Eso sí no podía aceptarlo él la quería demasiado y supuesto que había aceptado la cena, debía cuando menos darle un beso, en la boca, ardiente, apasionado. Miss Eva se echó a reír y Fernando, medio ebrio, quiso tomarse por la fuerza lo que voluntariamente le negaba. Comenzó una lucha en que él llevaba la peor parte por más que Miss Eva se limitara a rechazarlo con suavidad: hasta que, impacientada por las necedades de Fernando, se irguió y con ademán viril le asestó un golpe de clásico pugilato que dio con el pobre enamorado sobre el canapé. Lo menos le había saltado tres dientes! $(\text { sic })^{188}$

El odio desatado en el bandido consiste, en este caso, en evitar cualquier tipo de contacto físico con su enamorado; por lo contario, si llegara a tolerarlo habría cometido un hecho peor que el más grave delito a lo largo de su trayectoria como filibustero. Fernando, por su parte, al final de texto, cuando se entera de que su amada Eva es, "en realidad", un varón decide

\footnotetext{
${ }^{187}$ Daniel Borrillo, Homofobia (Barcelona: Bellaterra, 2000), p. 93.

188 Gamboa, pp. 108-109.
} 
alejarse de la vida pública. Sin duda, en el caso de Fernando la situación es más detestable y humillante todavía, ya que él fue quien propició el acercamiento y, además, quedó, ante la sociedad de la capital mexicana, como el peor de los ilusos.

Sería bueno recordar en este punto lo que Octavio Paz menciona al respecto de las diferencias entre el hombre y la mujer, así como entre el heterosexual y el homosexual, en la sociedad mexicana. Paz acota en "Máscaras mexicanas" la constitución del ser "macho", que debe llevarse a cabo con una negación absoluta de lo femenino -definido por el propio autor con base en "la rajada"-. Además, estos dos binomios satisfacen las necesidades de construcción y estabilidad de una colectividad creando lo permitido y elogiado con base en su negación: lo abyecto y, por ende, abierto.

La negación de Fernando a la vida pública articula toda una perspectiva homofóbica y un rechazo a ser vilipendiado por sus congéneres. Su prestigio ha sido destruido y, por tanto, el espacio que le resulta más factible es el exilio en su propia casa. Obviamente, este ostracismo no conlleva un cambio geográfico, como sería el caso de numerosos autores y personajes de la literatura hispanoamericana, sino que se traza más bien desde una situación relacionada con lo público y lo privado. Mientras el personaje esté "resguardado" de la mirada pública no será objeto de escarnio y, al menos, evitará pasar malos ratos con frecuencia.

La identidad del "macho" mexicano queda bien definida en este rubro: el "no rajarse" se asume como la negación a la violencia verbal y simbólica ejercida por el resto de la población; no obstante, el "retiro" o exilio del ámbito público implica también una cercanía con el hábitat de lo femenino. Aquí debe recordarse el espacio privilegiado para las mujeres enarbolado a lo largo de todo el siglo XIX y antes en México: la casa. Comparando esto con la situación de Fernando hay, ciertamente, una feminización, pero se asume en un menor 
grado que con la posible identificación con el "invertido", cuyos estragos serían impíos y desgarradores para el personaje.

Ahora bien, la presencia de Eva viene a definir en el cuento todas aquellas jerarquías relacionadas con el género. A lo largo del mismo, existe un repaso por ciertas formas de ser de lo femenino y lo masculino. Se coloca una clara división entre ambos espacios y se propone una inmovilidad de los mismos. El ardid del travestimiento, más que proponer una sanción, advierte todas las formas simbólicas de entender a la sociedad y el abigarramiento de sus costumbres. No se trata tampoco de un texto didáctico, pero sí guarda una idea clara de la colectividad representada, ya que, en ciertas ocasiones, el narrador se extraña del suceso contado, pero pone mayor énfasis en la visión tenida por el resto de los personajes. Esto es claro por la línea del naturalismo manejada por Gamboa en la medida en la cual el autor trata de colocar ante los ojos del lector el panorama más nítido posible del entorno social, anotando desde las costumbres más adecuadas hasta las más peyorativas o humillantes. Lo último queda bien delimitado en la novela más encomiada y famosa del autor, Santa. En dicho texto, como es bien sabido, la protagonista pasa de un estado de inocencia a la perversión generada por el entorno adverso y la pobreza, hasta convertirse en una prostituta muy solicitada y, después, en un ser frágil y enfermo al que sólo la muerte le queda como refugio y retorno al estado inicial. Incluso, en la misma novela tiene cabida un pasaje homoerótico, en el cual la "Gaditana" manifiesta su amor por Santa, amor que es descrito por Hipo, el ciego, como algo denigrante y asqueroso, a lo cual la protagonista de ningún modo tiene que acceder. 
Exploración (1921-1960)

Los cuentos analizados en el presente apartado articulan una diégesis profundamente disímil entre sí. A diferencia del apartado anterior, en el cual la presencia de la circunstancia homoerótica era puesta en evidencia mediante una situación llevada al límite, los textos que a continuación serán estudiados guardan una relación menos estrecha: si bien el punto de unidad entre los tres es la cuestión de la "disidencia sexual" de un protagonista masculino, no existe otro enclave de cercanía entre ellos. "Retrato de un estudiante" (1929) de Jaime Torres Bodet, "Los machos cabríos" (1952) de Jorge Ferretis y “Los Malabé” (1959) de José de la Colina poseen historias sumamente diferentes; los protagonistas de cada uno de estos cuentos atraviesan el ámbito del homoerotismo en un movimiento que, sin lugar a dudas, parece oscilar entre el rechazo más absoluto y la aceptación más sublime. Esta circunstancia puede explicar desde el hecho literario el cambio de paradigma social ocurrente en México durante las fechas señaladas en el título del presente apartado. La primera mitad del siglo XX es una turbulenta sacudida con respecto al canon de la sexualidad decimonónica, lo cual no necesariamente implica un ámbito de inclusión con respecto al "disidente sexual”, pero sí una apertura que muestra un discurso diferente con respecto a éste. José, Filemón y Francisco, protagonistas de los cuentos ya anotados, crean una discusión entronizada entre una conducta $^{189}$ sexual subversiva y un dispositivo de la sexualidad hegemónico. Esta discusión -y más que discusión el término correcto podría ser "lucha"-ocurre en dos sitios diferentes:

${ }^{189}$ La palabra "conducta”, en este caso, puede ser más útil que la de "identidad", 
el espacio individual y el colectivo. Desde una perspectiva extrínseca, el primer ámbito resultaría más libertador y entusiasta que el segundo; sin embargo, una vez inmersos en el análisis de cada texto, se descubre un equilibro entre ambos espacios: la colectividad es profundamente demoledora, en cuanto a una sanción social sobre el cuerpo se refiere, pero el sitio de la individualidad es una cruel desintegración del sujeto a partir de su propio deseo, además, de forma clara, la primera alimenta a la segunda y viceversa.

El ejemplo de la situación aquí relatada es "Retrato de un estudiante", en este texto, el narrador heterodiegético articula un caprichoso discurso sobre la compleja personalidad en pleno proceso de transformación- de su protagonista, José. Dicho proceso de cambio en el personaje se debe al tránsito de la infancia a la adolescencia y a las venturas y vicisitudes que el transcurso conlleva. No cabe duda entonces de que se trata de un cuento de iniciación, en el cual hay una etapa de pérdida y, a la vez, otra de aprendizaje. No obstante, el cambio no sólo está fundamentado por cuestiones relativas a la edad, sino por el plano de la sexualidad. José descubre, mediante comparaciones con el resto de sus compañeros de clase, cierta afinidad y, a la vez, rechazo. Igualmente, opera una relación de amor/odio con respecto a su entorno familiar, el cual le ha producido placer y afecto, pero, al mismo tiempo, le causa estragos en cuanto a su manera de percibir el mundo y, por supuesto, anclaje a una clase social y un determinado habitus asfixiante.

En primer lugar, el texto inicia con la pregunta que, Rafael Henríquez, compañero de clase del protagonista, le hace a éste: "Y usted ¿aprendió el francés en México?” Este cuestionamiento reviste varios planos simbólicos explotados de forma directa por el narrador al acercarse, en un estilo indirecto libre, a la conciencia del personaje; sin embargo, hay otros simbolismos que aparecen de forma connotativa, cuyas particularidades el lector debe descubrir. Los planos más evidentes radican, sobre todo, en contextos relacionados con la 
clase, el nivel cultural y el lugar de origen. Ante la pregunta del personaje interrogador, el protagonista siente, como a lo largo del cuento se desarrollará, una gran inquietud desde un aspecto denigrante y otro positivo, cuya extensión sobrepasa al primero. El aspecto denigrante está relacionado con la situación económica tan diferente de José y Rafael: mientras el protagonista pertenece a una familia provinciana de clase media, el otro joven posee unos acaudalados padres capitalinos. Esta diferencia repercute innegablemente en la percepción de Rafael tenida por José, quien está seguro de que un acercamiento de este modo sólo puede deberse a una actitud hostil, con la intención de remarcar las diferencias entre ambos a partir de la exaltación del trabajo escolar de más desafortunado económicamente. A este respecto, el narrador menciona:

No era la primera vez que José advertía la admiración afable de Rafael Henríquez pero, hasta entonces, le había desagradado profundamente. No quería analizarla por temor de hallar en ella un poco del disimulado desprecio que los estudiantes ricos ponen siempre en estimar la labor resignada de los pobres. Su reputación de inteligencia, la brillante historia escolar de que se sentía precedido, le parecían sumamente ridículas frente a la distinción natural -él decía: heredada-, de Henríquez. A algunas insinuaciones había creído útil responder con irrespetuosos desdenes. Un día, al terminar de exponer en Botánica, los defectos de la clasificación de Linneo, en vez de agradecer la felicitación que Henríquez se acercaba a ofrecerle, pasó junto a él sin mirarlo, haciendo un doloroso esfuerzo por no apartar la vista del marco de cuatro facetas que tallaba la oscura puerta de salida sobre el diamante duro del corredor. 190

El posible escarnio sentido por José a través de los actos efectuados por Rafael para elogiarlo tiene su origen en la diferencia de clase social ya señalada, pero, a su vez, en el trato

${ }^{190}$ Jaime Torres Bodet, El juglar y la domadora (México: Colmex, 1992), p. 42. 
dispensado por el resto de sus compañeros cuando acudía a la escuela primera en la provincia. Mientras en la capital el protagonista advierte en Rafael cierta displicencia, orgullo y deseos de fastidiarlo, en la provincia estaba rodeado de una suerte de compañeros que favorecían su ego y lo veían como a un líder: "En la escuela primaria no había aceptado sino esclavos. Orgulloso de su inteligencia, de sus zapatos de charol y de los mapas que, para los exámenes de Geografía, su tía le ayudaba a dibujar sobre grandes trozos de pergamino, manejaba a sus compañeros como a un pueblo de súbditos”. ${ }^{191}$ Hasta aquí, la noción de diferencia está dada a partir de rasgos que, si bien condicionan al cuerpo, no necesariamente emanan de su representación: clase y lugar de origen son dos condiciones que elevan o disminuyen -en el plano de la colectividad y, claro está, en el de la individualidad- el prestigio del individuo. La sensación de inferioridad padecida por José ante la presencia de Rafael, surge como una grave atadura e, igualmente, como una afrenta que, paradójicamente, sólo es concluida con la pregunta inicial del cuento. Recuérdese aquí la importancia del francés, en el ámbito de la sociedad mexicana, como una lengua cuyo aprendizaje estaba determinado por una cuestión de elegancia y solvencia económica. De este modo, Rafael -de forma imperceptible seguramente para él, pero indudablemente clara para José- coloca al protagonista en un nivel social y económicamente elevado: "Lo que agradecía ahora, en la pregunta de Rafael, no era el elogio de una virtud escolar -puesto que el francés no lo había cursado en la preparatoriasino la idea de que pudiese competir en un aprendizaje elegante con ese hijo de rico, que llegaba a la escuela en automóvil y veía el tiempo girar en su reloj de pulso, con sus manecillas de oro dentro de una órbita de platino". ${ }^{192}$ Hasta este punto estarían anotadas la posibilidades simbólicas, peyorativas o positivas, desarrolladas por el narrador a partir de la

\footnotetext{
191 Loc. cit.

192 Torres Bodet, p. 40.
} 
pregunta planteada por Rafael; no obstante, hay ciertos guiños en el cuento que proporcionan otras posibilidades de lectura, entras las cuales puede incluirse cierto flirteo homoerótico. Desde el principio, el acercamiento de Rafael genera desasosiego en José por las circunstancias ya detalladas, pero va más allá. El narrador señala en el segundo párrafo del texto cómo el encuentro entre ambos personajes tiene cierto toque de ambigüedad: "José y Rafael se habían encontrado de pronto reunidos -sin quererlo- por uno de esos caprichos de la casualidad que en la adolescencia acusan siempre una intención oculta muy directa" ${ }^{193}$ ¿A qué se refiere el narrador con este capricho: a un suceso relacionado con la condición de diferencia económica o, una vez salvaguardada esta lejanía, a una posible complicidad fincada en un hecho que solamente ellos conocían? Por la pertenencia de Torres Bodet al grupo de los Contemporáneos, resulta casi ineludible mencionar la arraigada tradición homoerótica enclavada en el quehacer poético de algunos de ellos, como Salvador Novo, Carlos Pellicer o Xavier Villaurrutia. Sobre este último, vale la pena cita el "Nocturno de los ángeles", en el cual, al igual que en "Retrato de un estudiante", hay una alusión directa a cierta complicidad: "Se diría que las calles fluyen dulcemente en la noche. / Las luces no son tan vivas que logren desvelar el secreto, / el secreto que los hombres que van y vienen conocen, / porque todos están en el secreto / y nada se ganaría con romperlo en mil pedazos / si, por el contrario, es tan dulce guardarlo / y compartirlo sólo con la persona elegida". ${ }^{194}$ Este secreto, en el caso del cuento de Torres Bodet, está relacionado con este asunto de empatía con respecto al deseo, puesto que, en una hermosa sinécdoque, el narrador plantea los ojos y, de forma general, el rostro, como los medios de expresión de Rafael, cuya

\footnotetext{
${ }^{193}$ Idem, p. 39.

194 Xavier Villaurrutia, "Nocturno de los ángeles” en Nostalgia de la muerte (México: Fontamara, 2010), p. 51.
} 
connotación apela a una situación erótica. En el caso de los ojos, el asunto es claro desde el principio: José se observa en los de Rafael, y encuentra en ellos una "alegría diáfana de tres colores: azul, amarillo y rojo". ${ }^{195}$ Más adelante, nuevamente es la mirada quien delata esta complicidad y la ambigüedad generada por la misma, esto ocurre en el hecho mediante el cual Rafael decide desviar su vista de la correspondiente a José. El narrador alude en esta escena al motivo de una superioridad en el dominio del francés por parte de José -quien justifica su notable capacidad lingüística por el supuesto origen francés de su familia-, y después sigue el enrojecimiento del rostro de Rafael: "De una blancura lechosa, su cutis tenía-como el de ciertas mujeres- reservas infinitas de rubor. En un segundo se tiñó de tal carmín espontáneo que José, por modestia, hundió sus manos en la nieve del cuaderno intacto y empezó a copiar ecuaciones del pizarrón". ${ }^{196}$ Después de este acontecimiento entre los dos personajes, el narrador parece olvidar por completo a Rafael y se sumerge en la figura de su protagonista. Mediante el mismo estilo indirecto, trae a colación varios recuerdos sobre la vida anterior de José: su infancia y la cotidianidad familiar en el espacio de la provincia.

Antes de continuar, cabe destacar aquí una clara relación con el ámbito de lo femenino con base en dos elementos: el rostro y el cabello, que corresponderían a Rafael y José. En la cita ya anotada, el narrador acota que el rostro del primer personaje mencionado tiene cierta semejanza con el de las mujeres. Después, cuando José recupera algunas escenas de su niñez, destaca el hecho de sentirse impotente ante el acicalamiento de su cabello por parte de su madre mediante unas tenazas para rizarlo. Sin duda, estos elementos traen a colación la novela Historia de Chucho "el Ninfo", de José Tomás de Cuéllar: al igual que en el texto citado, hay en "Retrato de un estudiante", una equiparación -o, según sea el caso, cercanía-

\footnotetext{
195 Torres Bodet, 39.

196 Idem, 41.
} 
del protagonista con respecto a las características de lo femenino. Claro está que en la novela mencionada el hecho no acude a una situación homoerótica, al contrario, opera una corrección en el carácter de Chucho; sin embargo, en el cuento de Torres Bodet sucede lo opuesto: lejos de negar el personaje un posible deseo homoerótico, lo acepta.

Al principio del análisis de "Retrato de un estudiante", fue enfatizada la circunstancia del tránsito del personaje como uno de los fundamentos de la diégesis. Efectivamente, el cambio de la provincia a la ciudad -lo cual genera el enfrentamiento con un mundo ante el cual el protagonista no se siente con armas suficientes- y el paso de la infancia a la adolescencia son elementos imprescindibles del texto; no obstante, ocurre otro relacionado con el tránsito y aceptación de una sexualidad diferente a la hegemónica, representada sobre todo por el ámbito familiar.

El narrador describe esta escena ambigua entre José y Rafael, pero una vez que deja a un lado a este personaje, se adentra en la relación de admiración/envidia entre José y el resto de sus compañeros de clase. Posteriormente, el protagonista decide obtener como premio, ante la mención especial dada por su maestro de álgebra, una comida en el restaurante del padre de uno de sus compañeros. Este acontecimiento, en apariencia trivial, tiene un sentido que detona la segunda parte de la historia de cuento, puesto que, en dicho lugar, José comienza a sentir cierta relajación por los efectos del vino obsequiado por su padre: "La embriaguez del vino nuevo lo había hecho descubrir el paisaje interior -red fluvial ahora cristalizada- de sus nervios, pero su padre, deseoso de agasajarlo completamente lo arrancó a la única dicha verdadera de su día de vacaciones para conducirlo al cine". ${ }^{197}$ El narrador no aclara mucho sobre los alcances del festejo; sin embargo, es fácil advertir un trastrueque en

\footnotetext{
197 Torres Bodet, p. 44.
} 
la visión del personaje con respecto al resto de sus compañeros de clase: en lugar de sentir esa mezcla compleja entre admiración y envidia, comienza a experimentar cierto desinterés. Ahora ocurre un efecto de idealización y, súbitamente, todas las claves para interpretar el hecho son vertidas:

Todos sus compañeros le habían parecido demasiado sólidos. Le molestaba su misma calidad de persona, de entidades reales. ¿Cuándo se atrevería a confesarlo? Empezó a leer novelas. Aprendió de memoria algunos párrafos llenos de frases sentimentales. En vez de pensar en una mujer a quien dedicarlos, era siempre la figura de un amigo ideal al que creaba, con palabra inútiles, durante su soledad. Todos los jóvenes le parecían dignos de interés, menos los que trataba. De estos simulacros de su sensibilidad desviada, volvía no obstante, siempre, sobre sí mismo con la constancia de un caballo de madera [...] La vida, la misma vida que estaba fabricando en él su azúcar, su corteza, su madurez y su viciosa fermentación, había endurecido, en el espíritu de su padre, una sucesión de valores plásticos cuyo único mérito -¡José hubiera sentido vergüenza de admitirlo!- era, exclusivamente, ornamental. ${ }^{198}$

Cabe destacar dos cosas aquí: en primer lugar, la alusión directa a la homosexualidad del protagonista y, en segundo término, la calificación hasta cierto punto negativa de la misma. Sin lugar a dudas, se trata del primer cuento de la tradición literaria mexicana que toca de forma directa el hecho y, además, en el cual se asume el personaje como tal, puesto que los tres cuentos analizados en el apartado anterior si bien abordaban el tópico del travestimiento y, de forma indirecta, poseían una señalamiento a un posible encuentro erótico, no ocurre un proceso de reflexión sobre el hecho ni una asimilación. En cambio, como puede observarse, en "Retrato de un estudiante", la situación es muy diferente. El estilo indirecto libre del narrador produce la idea de un monólogo interior en el protagonista, mediante el cual el lector

\footnotetext{
198 Idem. pp. 45-46-
} 
se entera de forma muy íntima de aquello que el personaje desea o rechaza. Con este posible monólogo interior, la presencia de la circunstancia homoerótica es mucho más cercana; así, la cuestión se torna desafiante con respecto a un sistema de género.

Como ya se dijo en el primer capítulo de este trabajo, la Revolución Mexicana trajo consigo todo un cambio de mentalidad en el país y, en el plano de la sexualidad, ocurre algo parecido. Para fines de la década de los veinte, que es cuando ocurre la publicación del cuento aquí estudiado, hay cierto aire de cosmopolitismo en la Ciudad de México. Sin duda, mucho ayudó a este respecto la figura de los Contemporáneos. Por estas razones destaca el cuento, ya que si bien aborda de forma directa el hecho de la homosexualidad, el tono de "desprecio" con el cual se le denota es también paradigmático. Esto último se menciona dado que surge una pregunta obvia ¿cómo, si el narrador refiere sin "precauciones" la presencia del deseo homosexual en el protagonista -y, también, de forma clara lo observa sin mayor problema-, decide otorgarle una calificación negativa? "Sensibilidad desviada" y "viciosa fermentación" son dos adjetivos que recuerdan, sin ambages, la tradición del "invertido" y la perspectiva sobre el pecado contra natura tan difundido por la cosmovisión ibérica en Latinoamérica. Suena paradójico entonces una posible comunión entre el aceptar el hecho homoerótico y mostrarlo, a la vez, con un revestimiento negativo. Probablemente, esta aparente no correspondencia entre los dos elementos citados en el narrador sea una forma alegórica de poner el dedo sobre la llaga. Al respecto, Borrillo menciona:

Tal como la xenofobia, el racismo o el antisemitismo, la homofobia es una manifestación arbitraria que consiste en señalar al otro como contrario, inferior o anormal. Su irreductible diferencia le coloca al otro lado, fuera del universo común de los humanos. Crimen abominable, amor vergonzante, gusto depravado, costumbre infame, pasión ignominiosa, pecado contra natura, vicio sodomita, son algunos 
de los calificativos que han servido durante siglos para designar el sexo y las relaciones sexuales o afectivas entre personas del mismo sexo. Encerrado en el papel de marginado o excéntrico, el homosexual ha sido señalado por la norma social como pintoresco, extraño o veleidoso. Y como siempre el mal viene de fuera, en Francia se ha calificado a la homosexualidad como "vicio italiano", "costumbre árabe", "vicio griego" o hasta de "usos coloniales". El homosexual, también como el negro, el judío o el extranjero es siempre el otro, el diferente, aquel con quien toda identificación es imprescindible. ${ }^{199}$

Esta cita es muy interesante y vale la pena detenerse con cuidado en ella no sólo por el contenido propio, sino por la relación que éste guarda con el análisis del texto. En primer término, el rechazo está latente a partir de observar al otro a partir de la diferencia que guarda con el uno. De este modo, todo aquello que no puede corresponderse con la figura del observador o del grupo al cual pertenece debe ser repudiado. En el caso del cuento la maniobra es igual: la otredad es abyecta y, por esta razón, no puede tener cabida dentro de lo normal, la situación del rechazo es indiscutible desde el punto de vista del uno. El problema se incrementa cuando dicho rechazo se fractura a partir de la misma persona, es decir que si bien son dos instancias totalmente diferentes el narrador y el personaje, su cercanía a través del estilo del primero no se presta a dubitaciones. Por tanto, pareciera darse más un ámbito de empatía que de indiferencia. Ahora bien, en el caso del personaje esta situación, más que ser destructiva, resulta un hecho afirmativo del sujeto: José. Por tanto, similar a la relación de amor/odio establecida por el protagonista con el resto de sus compañeros de clase puede encontrarse entonces la relación ambivalente del narrador al respecto del asunto homoerótico: es claro, son dos entidades diferentes, pero a partir de la cercanía esto queda parcialmente disuelto y el proceso se torna más personal. Así, el rechazo mostrado por el narrador es, en

\footnotetext{
${ }^{199}$ Daniel Borrillo, Homofobia (Barcelona: Bellaterra, 2001), pp.7-8.
} 
buena medida, una situación casi de automarginación, dado que sucumbe al deseo de forma ambigua y, con esa misma envoltura, lo denosta.

Por otro lado, y con respecto a lo mencionado por Borrillo, hay cierta visión de extranjería en los personajes del cuento. Resulta paradójico y humorístico que cada país utilice a la homosexualidad como una identidad marginada con el objetivo de menospreciar e insultar al sujeto extranjero. En el caso de "Retrato de un estudiante", el francés representa esta situación: no debe olvidarse cómo, a lo largo de todo el siglo XIX y principios del XX en Latinoamérica, el llamar a un determinado individuo "afrancesado" constituía un sinónimo de invertido o sodomita, según fuere el caso. Lo más irónico en este caso es observar cómo los mismos franceses, según la cita anotada, usan este ardid para tachar de homosexuales a todo aquel que no corresponde con la nacionalidad gala. Lo que para ellos es el "vicio griego", para la sociedad mexicana fue, durante muchísimo tiempo, el "vicio francés". Es por ello que resulta interesante observar la coyuntura representada por la pregunta de Rafael dirigida a José, en la cual el francés se convierte en una posibilidad de comunicación, empatía y complicidad entre los dos.

Ahora bien, es necesario retomar cómo la homosexualidad, al igual que otras marcas sobre el sujeto para identificar/repudiar, tienen como base una circunstancia corporal: "El ‘sexo' no es pues sencillamente algo que uno tiene o una descripción estática de lo que uno es: será una de las normas mediante las cuales ese ‘uno' puede llegar a ser viable, esa norma que califica a un cuerpo para toda la vida dentro de la esfera de la inteligibilidad cultural”. ${ }^{200}$ A partir de este axioma, José puede ser observado como un sujeto en una lucha, cuya capacidad de violentar al individuo se advierte por diversos ámbitos: "el llegar a ser viable"

\footnotetext{
${ }^{200}$ Judith Butler, Cuerpos que importan, p. 19.
} 
implica sujetarse a un imbricado constructo de valores y normas, las cuales no quedan solamente en la mera circunstancia del sexo, sino que pueden ser llevadas a diversos ámbitos. En el cuento, desde el principio el lector se percata de esta contienda cuando José apela a una determinada representación social enfrentada por otra que le parece superior. Lo mismo sucede cuando encuentra su entorno hostil a partir de la presencia de lo familiar y, claro está, puede observarse a sí mismo como un ser diferente. Así, la demarcación de lo permisible y lo prohibido produce un grave escozor en el individuo, cuyas repercusiones lo transforman en un sujeto doloroso. Esta dualidad entonces genera una posibilidad de definir en el texto, a pesar de la posible asimilación del homoerotismo, una visión peyorativa del sujeto disidente: “Lo abyecto designa aquí precisamente aquellas zonas 'invivibles', 'inhabitables' de la vida social que, sin embargo, están densamente pobladas por quienes no gozan de la jerarquía de los sujetos, pero cuya condición de vivir bajo el signo de lo 'invivible' es necesaria para circunscribir la esfera de los sujetos". ${ }^{201}$ En este juego se construye la identidad que, en el caso del protagonista de cuento, es un evento detonador del periodo adulto.

En esta misma línea del conflicto de identidad, se halla el cuento "Machos cabríos" de Jorge Ferretis, publicado originalmente hacia 1952 en el conjunto de relatos El coronel que asesinó a un palomo y otros cuentos. En dicho texto, la presencia del problema con respecto al adjudicamiento de una determinada representación social sexo-genérica resulta muy evidente. El protagonista, Filemón, es un hombre que habita una destartalada vecindad del centro histórico de la Ciudad de México; sin embargo, la palabra "hombre", conforme a lo informado por el propio narrador y el resto de los personajes, constriñe, para el protagonista, un problema severo; puesto que, en apariencia, su tremenda musculatura e

\footnotetext{
201 Idem, p. 20.
} 
impresionante corporalidad destacarían por encima de cualquier ejemplar de este género, pero, sus "modales" y voz permiten, a los habitantes de la vecindad, hacer una relectura de la posible identidad "abyecta" de Filemón.

Narrado en un tono muy cercano al naturalismo -debido, sobre todo, a un estilo más descriptivo y costumbrista, aunado a la existencia de personajes correspondientes a ámbitos periféricos, desde el punto de vista económico, social y sexual-, el cuento aglutina un estadio muy "adecuado" con respecto a los valores genéricos tenidos, seguramente, hacia la década de los cuarenta y principios de los cincuenta sobre la disidencia sexual.

En primer lugar, el narrador, si bien permanece un tanto "aislado" de la diégesis exhibida, ya que se dedica en un buena medida sólo a describirla y contarla con una ausencia de juicio moral, hace hincapié subrepticiamente hacia la representación de Filemón, en su mayoría sobre el juego de oposiciones establecidos entre el "ser" y el "parecer". No obstante, quien en una dimensión exagerada practica este tipo de afición es la portera de la vecindad en la cual habita el protagonista, doña Angelita. Este personaje, a cada momento, posee una visión bastante peyorativa sobre Filemón y, a la menor provocación o deseo de instaurar su posible autoridad por encima de los demás inquilinos de dicha propiedad, manifiesta su descontento al respecto de la identidad del mismo en los lacerantes diálogos anotados por el narrador: "-Es más apto para las labores del hogar [...] Yo no digo que no sea excelente persona [...]. Lo que digo es que sólo le falta poder servir de nodriza. ¡Sería tan feliz!" ${ }^{202}$ La sima de esta degradación se da cuando coloca sobre Filemón uno de insultos favoritos por parte del dispositivo normativo de la sexualidad mexicana: "Para tan extraño Filemón, la mofadora inventa un mote que el cae mejor que su ropa: se debería llamar Don Marica". ${ }^{203}$

\footnotetext{
202 Jorge Ferretis, El coronel que asesinó a un palomo y otros cuentos (México: Tezontle, 1952), p. 25.

${ }^{203}$ Loc. cit.
} 
Resulta un tanto alegórico el hecho de que el narrador compare el apelativo lanzado sobre Filemón con la ropa. La casualidad no es extraña en este caso, en la medida según la cual parece que, quien cuenta, alude a la caracterización cultural de la ropa y la identidad sexual. La comparación permite entonces crear un universo de correspondencias absolutamente sociales sobre las que está sostenida la conveniencia de cada una de las diferentes representaciones sexuales. Sin embargo, sería demasiado aventurado señalar que este paralelismo tiene como base dicho simbolismo, cuando, posiblemente, a lo que el narrador apunta es al acomodamiento de una "etiqueta" en cuanto a su capacidad de denominación sobre el personaje para devenirlo sujeto.

El insulto funciona para de marcar una distancia con el personaje y colocar de manifiesto los rasgos que, claro está, al momento de proferir la palabra se pone en juego. Igualmente, éste es el punto de partida del revestimiento simbólico y temático pronunciado a lo largo del cuento sobre Filemón. Desde esta perspectiva, el universo del protagonista se torna hostil, pero, a la vez, genera cierto desasosiego en los otros por lo cual inmediatamente queda incrustado al centro de la vida pública y privada de la vecindad. De este modo, cada vez que Filemón escucha sobre sí el insulto no le queda otra opción más que permanecer en el mutismo y, de cierta manera, se constriñe en su propio mundo para tratar de eludir la carga peyorativa de la denigración: "El propio Filemón sonríe desteñidamente cuando se lo participan [el insulto], e inmune a la vejación, sigue viviendo igual para sus minúsculos amos [los niños]". ${ }^{204}$

El aspecto lúdico y, hasta cierto punto, teatral del cuento entra en escena cuando este hecho del "ser" y el "parecer" se vuelve más eficaz a partir de ciertos conflictos desatados en

\footnotetext{
${ }^{204}$ Ferretis, p. 25.
} 
la vecindad. El primero de ellos consiste en un terrible incendio que ha consumido buena parte de la construcción y una de las familias habitantes de la misma, por descuido, deja a una niña dentro de ella. En este caso, se forma inmediatamente un terrible caos entre todos los partícipes del hecho y, sobre todo, en los padres; no obstante, como Filemón tiene predilección por los infantes y, a la vez, posee un gran sentido de humanidad, decide arriesgar su vida aun a costa de los posibles daños que, sobre su físico, pudieran recaer: "Y es entonces cuando hacia el resplandor se destaca, segura, pesada, la mole de Filemón. Llega frente a la puerta que retuerce su manojo de llamas. Aprieta los brazos sobre su rostro, y avanzando de espaldas, desaparece. Es como dejarse tragar por una carcajada de infierno". ${ }^{205}$ Más adelante, el narrador señala cómo Filemón rescata de entre las llamas el cuerpo con vida de la niña para entregarlo a su madre: "La madre corre a encontrarlo a las escaleras, para recibir su envoltorio. Al cerciorarse de que su niña patalea y gime, lanza otro alarido ¡Ya no esperaba que la sacasen vida!"206

Inmediatamente después de este hecho, Filemón se transforma, a pesar de su posible carácter y representación abyecta, en un héroe para la pequeña colectividad que lo rodea. Incluso, el narrador inicia un extraño juego entre la "masculinidad" del padre de la niña que ha rescatada Filemón y éste, con el fin de señalar el entredicho en el cual queda aquel personaje y el desasosiego mayor generado en los vecinos ante los repentinos "ataques de masculinidad" generados en "Don Marica": "El padre, ínfimo en su nulidad, no dice una palabra. Las que desean dar algunas palmaditas a Filemón no lo hallan, pues hasta que merma el fragor, dos bomberos aparecen con él en peso. Un resbalón lo había inmovilizado entre la

\footnotetext{
${ }^{205}$ Idem, p. 24.

${ }^{206}$ Loc. cit.
} 
tormenta. El peso de su propio volumen, y la tajadura con una baranda rota, le han abierto atroz herida entre las piernas". ${ }^{207}$

El andamiaje simbólico de "Los machos cabríos" entra una dialéctica mayor al colocar, en un espacio tan breve como el de la cita anterior, una correlación de sentidos: la inadmisible disminución de la masculinidad del padre de la niña rescatada y la herida obtenida, casi a modo de premio, por parte de Filemón. En el primer caso, el narrador apuesta por la concepción de una familia articulada en un los ejes paradigmáticos de dicha institución creados en el México decimonónico y acrecentados en el posrevolucionario. La representación del varón como padre y protector de la familia se ve absolutamente mermada con la presencia de un hombre soltero y que, además, posee una identidad sexual con carácter de incertidumbre. Nuevamente el juego de dicotomías y oposiciones gestado en el cuento brota al señalar el endeble y cobarde carácter del padre con respecto al inusitado brío de Filemón, del cual se hará alarde más tarde en el avance de la diégesis. Por otro lado, la herida de Filemón connota, sin duda, el señalamiento directo a los genitales del personaje, en los cuales, por razones "naturalizadoras" del habitus mexicano, se concentra todo el peso de la masculinidad, ¿apunta entonces la herida a una disminución o a una enmienda en cuanto a género se refiere?

Por razones obvias, ambos personajes, el nuevo héroe Filemón y la niña rescatada, son llevados al hospital para iniciar su recuperación. Justo en este proceso se ha producido cierto "cambio" en la actitud de los personajes: "En la vencindad, lo mencionaban con respeto [a Filemón]. Nadie hubo que remedara su tono delgaducho. Hasta convencían al padre de la niña para que fuese a darle las gracias, más la portera cooperó: -¡Naturalmente debe ir! Hará

\footnotetext{
${ }^{207}$ Idem, pp. 28-29
} 
provecho a Don... Filemón, ver lo que valen junto a él los hombres de esta vecindad". Claro está que en los puntos suspensivos señalados en el diálogo de Angelita se resguarda una contundente carga peyorativa, ese "Don..." no es más que un marcaje evidente del afeminamiento del personaje y su anclaje al ámbito homosexual. A su vez, sirve de doble insulto: por un lado recuerda que, si bien Filemón es un héroe, no deja de ser "maricón"; por el otro, conlleva una agravante más hacia los supuestos varones de la vecindad que, poco o nada, hacen ante la presencia del incendio, acentuando con ello una carga peyorativa mayor sobre ellos, ya que estarían en un nivel de prestigio inferior al del protagonista. Por supuesto, este convencimiento no es más que un insulto directo al padre, el cual desiste de agradecer a Filemón, debido a su indignación de tener una hija, con diversas quemaduras, rescatada por "Don Marica".

Quien no deja a un lado la visita es la portera. Así, en su posición de superioridad en la vecindad se convierte en la única autoridad posible: "La portera hizo una visita de buena educación al enfermo. Él, a pesar de su rostro tan vendado y de sus dificultades para oír, escuchó todo el chismerío, y se recrudecieron sus ardores". ${ }^{208}$ Este hecho, sin menoscabo de prestarse a una sobreinterpretación, condensa una dualidad sobre un daño ejercido tanto sobre el cuerpo del protagonista como sobre su espíritu: hay un deseo de "ofrecer" cierto afecto y agradecimiento hacia el enfermo; sin embargo, esto no es más que una coartada para continuar con el insulto. Nuevamente, salta a la vista una cuestión alegórica debido al doble daño, moral y físico, ejercido por parte de un dispositivo de poder hacia los posibles representantes de una identidad sexo-genérica disidente. Podría observarse entonces que la portera funciona, en el texto, a modo del clásico "ojo sancionador" que toda sociedad posee

\footnotetext{
${ }^{208}$ Ferretis, p. 29.
} 
con el fin de delimitar claramente la matriz de identidades prestigiadas frente a las abyectas. La visita de Angelita más que una ironía es una clara alusión hacia los irremediables manifiestos tangibles e intangibles que dicha sociedad, en su afán de satirizar y corregir, ejerce sobre los habitantes "anormales".

No obstante, la situación se torna más cruda con la presencia de un hecho que determinará la composición del cuento y la remembranza del discurso higienista decimonónico: la concepción de la homosexualidad o un determinado estado afeminado como una enfermedad, la cual es susceptible de curarse y devolver, al sujeto que la posee, a un "correcto" cauce vital y social. Cuando Filemón, aturdido por los dolores de la herida y por el recordatorio de su situación denigrante por parte de la portera, convalece en su cama, un estudiante de medicina, que seguramente estaba iniciando su actividad profesional justo en el hospital donde permanece el protagonista, lo hace firmar un par de documentos en los cuales autoriza la realización de una cirugía que poco tiene que ver con las quemaduras. El narrador describe al practicante del siguiente modo:

Aquel médico en ciernes preparaba su tesis profesional, y tenía pasión por lo extraordinario. De su pueblecillo del Norte, traía el recuerdo de un jinete, que había tenido fama de que ni borracho lo tumbaría una bestia. Hasta de impunidad gozaba, y en los alrededores lo veían como terror de viejas con hijas guapas. Al fin, lo castigó un toro prieto que lo tiró por el aire; lo alcanzó con cuerno; el abrió infernal garranchón, y lo atrofió. Se hizo legendario el toro-penitencia, y aquello no fue todo, sino que el castigo empezó a engordar, adiposo. Cambiaban su caracteres somáticos; perdía sus atributos, y cuando hasta sus modales produjeron comentarios malévolos, aquel despojo de hombre se dio un tiro. ${ }^{209}$

${ }^{209}$ Ferretis, p. 30 
La concepción brindada por el cuento al respecto de la homosexualidad es clara: el hecho de que un hombre pierda su masculinidad o, desde el nacimiento, la tenga disminuida es sólo una circunstancia corporal indeseable, la cual puede ser solventada gracias a los avances de la medicina. Así, y como se mencionó anteriormente, esta cuestión plantea un lazo directo con la herencia del discurso higienista. Recuérdese aquí lo anotado en el primer capítulo de este trabajo, en el que se mencionó como la visión sobre el tema de la disidencia sexual pasó de ser un hecho sancionado por la iglesia en la figura del "sodomita" a erigirse en un asunto de carácter médico-jurídico con base en la invención de "homosexual" o "invertido". "Los machos cabríos" recupera entonces esta cuestión y la coloca sin mayor aspaviento en la literatura mexicana y, tal parece, persiste un deseo de ofertar cierta imagen sobre el "maricón" no con base en el menosprecio que su figura acarrea, sino en la búsqueda de una solución a dicho problema. Esto funciona de modo muy similar al que, a lo largo de todo el porfiriato, se trató a la prostituta con el fin de mantener "limpias" las ciudades de dicho vicio y permitir la construcción de una sociedad con valores afirmados en una sexualidad reproductiva, absolutamente ligada al ámbito de la familia, y no vinculada al hecho placentero, y mucho menos a la visión de una sexualidad deseada por el propio cuerpo femenino.

Hay, por tanto, el cuento un deseo de reformación y no de vituperio, aunque, paradójicamente, el primero lleva la impronta irremediable del segundo. "Don Marica" es un héroe, no hay duda de eso, pero su afeminamiento debe ser resuelto para que dicho héroe adquiera una consistencia de identidad socialmente aceptada. Así, el cuento ofrece una visión anclada profundamente al seno del México posrevolucionario, en el cual no había cabida para cualquier intento de disidencia sexual, debido, en buena medida, a la famosa edificación del "hombre nuevo" edificada después del movimiento armado. De este modo, 
queda perfectamente articulada la visión alegórica que le narrador pretende dar con respecto a una sociedad y los valores de género inscritos en la misma: la portera representa la voz popular, que si bien sanciona y tiene las posibilidades de marcar los errores de aquellos detractores de las "buenas costumbres", no posee la capacidad necesaria para elucidar más sobre el tema y se queda en un ámbito superficial; por lo contrario, el hombre instruido, en este caso el aspirante a médico, goza de la posibilidad de argumentar un juicio "científico" sobre el carácter disidente, con lo cual orienta la perspectiva y aporta "soluciones" para el mismo: "Con el inverso hallazgo de Filemón, el médico se entusiasmaba por ensayar un injerto. Para otros especialistas en glándulas de secreción, también era un espléndido caso experimental. Asexuado por irregular colocación y parcial atrofia testicular, acaso mediante un simple desplazamiento pudiesen corregir su condición humana". 210

De igual modo en el que Filemón es auscultado por la mirada voraz y cizañosa de la portera, los médicos observan también al protagonista semidesnudo sobre una mesa de exploración, en una de las escenas más culminantes y simbólicas del cuento: "Después de mucha paciencia entre aparatos, Filemón fue conducido a otro encierro blanco, donde todos hablaban como en antesala de capilla ardiente. Lo tendieron, descubriéndolo parcialmente, y lo empezaron a curiosear diez o doce espectros alarmantemente limpios". ${ }^{211}$ El resultado de dicha auscultación es la decisión de practicarle una cirugía al enfermo con el fin de corregir su problema fisiológico y "ajustar" su cuerpo e identidad a los moldes de conducta establecidos por el dispositivo del poder. A partir de este momento Filemón adquiere un nuevo revestimiento y deja de ser "Don Marica" para convertirse, finalmente, en un miembro del partido obrero. No obstante, antes de llegar a dicha configuración, el protagonista

\footnotetext{
210 Ferretis, p. 30

211 Loc. cit.
} 
atraviesa una serie de contratiempos, entre los cuales se encuentra el ser recluido en la cárcel debido a la protección que le otorga, dentro de su vivienda, a un joven ladrón, y el "atentado" creado sobre la autoridad al golpear a un policía.

A partir de este momento, el cuento crea la renovación de la identidad de Filemón; paulatinamente el personaje adquiere modales "masculinos" y, lo más importante durante esta etapa, conoce en la cárcel a Petra, una vendedora de tamales de quien el protagonista termina enamorado: "Una noche de insomnio, acabó reconociendo que la vida era un estúpido tormento sin su maravillosa tamalera. Tendría que hablare, y si ella lo aceptaba, no habría muros ni poderes humanos que lo retuviesen en aquel encierro." ${ }^{212}$ Este encuadre de la diégesis es un tanto extraño con respecto a lo que, tradicionalmente, ha despertado el motivo de la cárcel en la literatura hispanoamericana; recuérdese, a este respecto, la presencia de dos novelas Hombres sin mujer de Carlos Montenegro y El beso de la mujer araña de Manuel Puig. En ambas historias, los protagonistas tienen a realizar un proceso de transformación de su sexualidad y acaban internándose en los vericuetos del homoerotismo. Tanto el mulato habanero Pascasio como el revolucionario porteño Valentín descubren en la prisión una nueva forma de disfrutar de su cuerpo, claro está que, en buena medida, esta situación está influida directamente por la presencia única de varones en el recinto donde purgan su respectiva condena; sin embargo, este hecho es sólo un crisol que permite el surgimiento de aquellas deseos soterrados por un dispositivo hermético de la sexualidad en sus sociedades, Cuba y Argentina. En consecuencia, resulta muy llamativo el hecho de que Filemón, lejos de encontrar en la cárcel un espacio para el posible nacimiento de sus

\footnotetext{
${ }^{212}$ Ferretis, p. 37.
} 
pulsiones sexuales "disidentes", encuentre una renovación y el "camino adecuado", según los principios convencionales rectores del deseo en México, de su fijación erótica.

Si en un principio el "antiguo" Filemón sólo se divertía jugando con los niños de la vecindad donde habitaba, ahora, el "renovado" protagonista tiene la posibilidad de poseer un denodado deseo heterosexual. Además, aunado a esta circunstancia, Filemón establece una gran amistad con Diego, el joven a quien encubrió de la policía y por cuya causa fue llevado a la cárcel. Otra persona que no deja de frecuentarlo es el estudiante de medicina obsesionado por corregir el "desorden" fisiológico del protagonista y convertirlo en el "hombre" que, por "naturaleza", le correspondía ser. A tal grado llega la obstinación del principiante que consigue la libertad de Filemón mediante una solicitud realizada por la Facultad de Medicina. En un principio, este hecho es considerado por el protagonista como una situación deplorable; no obstante, recapacita y advierte de buena gana la suerte obtenida.

Durante este suceso, el estudiante le sentencia algo al protagonista que lo seducirá por completo: "No deje de buscarnos. Es usted un hombre". ${ }^{213}$ Sin duda, esta afirmación conduce a Filemón a un estado de superioridad con respecto a su situación anterior. La sola mención de la palabra "hombre" trae consigo todo un abanico de posibilidades de empoderamiento, mediante las cuales el protagonista tiene la posibilidad de redimir la carga peyorativa que lo había tenido asolado durante años. En consecuencia, "Don Marica" pasa de ser un sujeto periférico y objeto de mofa, a pesar de su notable corporalidad, a convertirse en un individuo con una identidad prestigiada, la cual funcionará como una coraza frente al resto de los hombres. La nueva y alabada etiqueta es una forma de subvertir cualquier intento de hegemonía por parte del entorno, aunque, paradójicamente, el sujetamiento a la misma

\footnotetext{
${ }^{213}$ Ferretis, p. 38.
} 
no hace más que confirmar su relación de "vínculo apasionado" con la norma que en un principio lo martirizó y, ahora, lo encumbra.

Para concretar su proyecto de "hombría", a Filemón sólo le queda continuar con el forjamiento de su nueva imagen "masculina"; pero, para llegar a esta meta, debe realizar una pequeña venganza sobre su principal detractora, Angelita. El hecho queda concretado con una serie de nalgadas propinadas por el protagonista hacia este personaje. Por tanto, con esta afirmación de su nueva identidad ya no hay resabios de cualquier intento de supeditación debido a los modales y la voz meliflua. Esta exacerbación del orgullo "viril" desemboca en la constitución de una personalidad con rasgos cercanos a los poseídos por la portera: Filemón adquiere una suerte de rechazo hacia cualquier tipo de afeminamiento y, a la vez, comienza a ser un censor de las conductas sexuales. Esto último se corrobora con su afiliación al partido obrero y sus elucubraciones manifestadas por el narrador al respecto:

Filemón se alejó sonriendo despectivamente, y calificando de torpes a gobernantes que no se preocuparan, específicamente, por la virilidad de sus gobernados. Los núcleos viriles han sido los que conducen siempre a los otros, como a lastimosas manadas. El músculo era cosa distinta, pues abundaban los campeones de olimpíadas muy escasos de hombría. Por añadidura, sería ridículo condenar a deportes a pueblos débiles, hambreados y con glándulas deficientes. De pronto, se detuvo pensado que su médico podría salvar también a las multitudes. Si las refaccionase con injertos glandulares, se acabarían los desvalidos. Así como los millonarios nuevos creen que todo conseguirán con dinerales, Filemón sentíase omnipotente, deño de una fortuna biológica que le parecía extraordinaria. ${ }^{214}$

El discurso social contenido en esta cita parece afirmar la relación entre la lucha de clases y la creación de una "masculinidad elevada" con el fin de dar respuestas "cabales" a los

\footnotetext{
${ }^{214}$ Ferretis, p. 42.
} 
problemas de una determinada colectividad. Esta situación recuerda el planteamiento contenido en la novela Los cuarenta y uno de Eduardo A. Castrejón, en la cual el narrador culpa del "vicio nefando" a las comodidades y destrucción de los valores fundamentadas por la oligarquía porfiriana. Recuérdese aquí que en el contenido panfletario de dicho texto hay una suerte de "sedición" con respecto al sistema político y social mexicano de las postrimerías del Porfiriato. De este modo, el hecho del famoso baile de los 41 le sirve, en buena medida, al narrador para crear un discurso contestatario con respecto al régimen instaurado en el país. En consecuencia, si la Revolución articula un nuevo dispositivo del poder con base en la exaltación del campesino y del obrero, no es demasiado difícil hilvanar esta concepción con la planteada en "Los machos cabríos". Incluso, puede fundamentarse esta hipótesis con los vituperios creados en torno al grupo de los Contemporáneos por su aspecto cosmopolita $\mathrm{y}$, en algunos de sus miembros, por su homosexualidad: el enfrentamiento entre una literatura "viril" y una "afeminada" aún tiene bastante eco entonces hacia la década de los cincuenta, lo cual va a continuar dando ímpetu para los últimos productos del nacionalismo cultural, el cual, sin duda, se verá colapsado hacia la década de los sesenta.

Otro aspecto que llama la atención, es lo que menciona el narrador después de la breve reflexión hecha por Filemón sobre el ámbito político:

Recordó páginas que le parecieron lumbre reveladora. Según la Biblia, los machos cabríos fueron colocados a la izquierda de Dios y las ovejas a su lado derecho. ¿No sería símbolo de la lucha social? A la izquierda los viriles, no importaría que les atribuyesen la maldad; y a la derecha los pasivos, no importaría que les obsequiasen la gloria. Unos para el denuedo fértil; 
otros para la castidad estérilmente seráfica. Dios mismo, a su izquierda, necesitaba el borbotón. ${ }^{215}$

Aquí la exacerbación de la "filiación masculina" es impresionante y está anclada, debido a la visión del personaje, a una estrecha relación entre la izquierda planteada en el pasaje bíblico y la denominación política. Las repercusiones simbólicas de este hecho están en relación directa con las transformaciones efectuadas sobre Filemón: no hay duda de que el protagonista ha dejado por completo la enfermedad de "Don Marica" y ha formado ya parte del dispositivo del poder. Además, este cambio resulta algo extraño debido a las formas de representación de la literatura de tema homoerótico, en la cual, con certeza, el tránsito siempre se realiza a la inversa: el personaje pasa de estar "ajustado" a unos parámetros de deseo para obtener su "libertad" en cuanto a su sexualidad se refiere. En el caso del cuento anterior, "Retrato de un estudiante", el descubrimiento de una "nueva sensibilidad" confirma este hecho y asume, por tanto, el camino hacia el posible comming out del protagonista. En otros casos, este hecho, si bien no se torna liberalizador, con frecuencia alude a las hegemonías del género que impiden el desarrollo del personaje con base en su propio deseo, como sería el caso de la mayoría de los cuentos del siguiente apartado: "Los amigos" de Juan Vicente Melo, "Doña Herlinda y su hijo" de Jorge López Páez y "De amor es mi negra pena” de Luis Zapata. En correspondencia con esta vertiente de la literatura homoerótica se encuentra el siguiente cuento que será analizado en este capítulo: “Los Malabé” de José de la Colina. ${ }^{216}$ En dicho texto radica una exhibición del tema del travestimiento, pero en una connotación diferente a la del apartado "Antecedentes", en el cual los personajes que

\footnotetext{
${ }^{215}$ Ferretis, p. 43.

${ }^{216}$ De la Colina, Jose. Ven, caballo gris, pról. de Juan Coronado (Xalapa: Universidad Veracruzana, 2007).
} 
adquirían un revestimiento genérico disímil al marcado por el dispositivo de la sexualidad no lo realizaban necesariamente por un deseo homoerótico, sino por un ardid para conseguir sus propósitos. En este sentido, "Los Malabé" articula una diégesis que muestra de forma directa el tema del personaje travesti pero en cuanto a su deseo sexual y no como mera forma de obtener un mejoramiento. Francisco Malabert, el protagonista del cuento, es un hombre mayor que vive atosigado por la presencia de sus hermanas, quienes lo cuidan como si se tratase de un niño y, además, tratan de imponer sobre él el peso de una moral familiar abrumadora. Así, el personaje, como muchos otros de los aquí estudiados, sobrevive en una suerte de cárcel simbólica, pero absolutamente tangible y arremetedora, que le impide concreta su deseo sexual y de género, ya que, su mayor yerro, ha sido vestirse con las ropas que, posiblemente, hurtaba de las hermanas.

Ahora bien, el acceso a la historia del cuento está dado por la presencia de un narrador homodiegético, Felipe, quien llega al pequeño puerto donde la familia Malabert posee la base de su enorme empresa cafetalera. Este personaje permanece en contacto directo con dicha familia y logra advertir cómo, a pesar de la riqueza, Francisco vive recluido con temores en el espacio asfixiante de su mansión. La presencia de Felipe está determinada por las necesidades de obtener, para su compañía, una disminución en el precio de una gran cantidad de café. Así, durante su estancia describe a Francisco del siguiente modo: "Aquella tarde como las anteriores, don Francisco me escuchaba cortésmente. Es decir, escuchaba mi voz, atendía a mi gesto, pero rechazaba las palabras, las ignoraba. Aún me pregunto qué había de irreductible en aquel mulato sesentón de piel casi azul, de labios finos, de recordado ademán y de elegante atuendo blanco". ${ }^{217}$

\footnotetext{
${ }^{217}$ De la Colina, pp. 47-48.
} 
No obstante, durante el tiempo que ha convivido Felipe con Francisco sólo obtiene un par de conjeturas que poco o nada llegan a decirle sobre las particularidades de la personalidad del empresario cafetalero. Advierte que la vida de Francisco es un tanto monótona, aburrida y hermética, que las hermanas del mismo, Rosario Dulce y Gloria de los Ángeles, son muy agrestes en cuanto a la convivencia con dicho personaje y, por último, que ambas ejercen una invariable influencia sobre Francisco. Quien en verdad brinda la totalidad de la historia sobre éste es un joven negro, Nepomuceno Sánchez, el cual llama a Felipe para conversar durante el paseo de reconocimiento por el pueblo por parte de este último. En dicha charla, Nepomuceno narra cómo Francisco lo invita a su mansión con el objetivo de ofrecerle una lancha con motor, tan anhelada por parte del joven. Una vez que ambos se encuentran solos en la habitación, debido a la asistencia de las hermanas a misa, Francisco se traviste con las ropas de Gloria y, posiblemente, mantiene un furtivo encuentro sexual con Nepomuceno, el cual es descubierto por las hermanas:

Avanzan por el pasillo, sus nerviosos murmullos apagados por el murmullo de las faldas, avanza y pasan a la sala, una alcoba, y luego otra -es la de Gloria de los Ángeles, y el armario muestras los cajones abiertos, desbordando ropas revueltas-, llegan a la habitación de Paquito, empujan la puerta, y entonces se han quedado inmóviles, como congeladas por un terrible fogonazo de magnesio: en la habitación, de pie, hay una mujer extraña, una mujer pequeña, de piel casi azul, de labios delgados, de ojitos que encierran un lento humo interior; luego una fugaz silueta negra y guinda ha saltado por la ventada, se oye su zambullida en el mar, mientras esa mujer, esa desconocida mujer de apellido Malabert, sonríe temerosa, recordando que cuento Paquito, hace muchos años, en la infancia, se disfrazó de niña, el entonces vivo señor Malabert lo castigó con dos meses de encierro en casa. ${ }^{218}$

${ }^{218}$ De la Colina, p. 48. 
Como se observa, el plano alegórico del cuento funciona del mismo modo que en "Los machos cabríos": la presencia de las hermanas y el padre como portadores del dispositivo del poder, que determina las conductas "adecuadas" para uno y otro género con base en una lectura de los rasgos fisiológicos, se hace patente mediante su brazo de autoridad y, claro está, de sanción. Sin duda, la mansión de los Malabert se convierte en el cuento en una representación del estado de la sociedad vigente y, a su vez, resulta absolutamente dominante en cuanto a la manifestación de su normativa. Tanto las hermanas, como la anterior presencia del padre, establecen un cerco y observación constante de cualquier rasgo de afeminamiento de Francisco o, peor aun, de un terrible travestimiento que sacude, por sí mismo, las bases de las adecuadas correspondencias del género. Así, el final del relato se traduce en la clave para entender las conjeturas advertidas por parte del personaje-narrador, quien observa cómo, durante su estancia en la casa Malabert, el trato entre Francisco y sus hermanas es bastante áspero y reducido sólo a lo más elemental, dado que la historia contada por el joven negro, a pesar de que es colocada al final del texto, es una gran analepsis reproductora de un hecho con un alcance de varios meses o, incluso, años.

Por otro lado, si bien Rosario Dulce y Gloria de los Ángeles están, indudablemente, en un plano de segregación creado por su condición "femenina", es preciso acotar también que adquieren un impetuoso espíritu carcelero. Esta circunstancia suena paradójica: la relación estrecha entre víctima y verdugo es algo que, con frecuencia, tiende a ser problemático, mucho más cuando queda establecido sobre un mismo individuo. Así, las hermanas pueden permanecer "acorazadas", pero no dudan en flagelar a otro sujeto con las mismas posibilidades de marginación. Claro está que este hecho no es casual y obedece a la reiteración constante de las hegemonías creadas sobre la linealidad sexo/género/deseo y su correcta aplicación en cada uno de los estratos y realidades sociales. 
Este tipo de discurso en el cual se reproduce el acto de vigilar y castigar a quien permanece sometido por parte de un designo "naturalizador" es muy claro en el caso de las mujeres. Puede decirse que la actual teoría queer tiene como antecedente uno de estos principios; por lo tanto, debe recordarse aquí cómo, a lo largo de la década de los setenta y sesenta, se llegó a la consolidación de cierto gueto entre una raza y clase de mujeres que perseguían intereses comunes bajo el amparo de la bandera feminista. En consecuencia, y debido al hermetismo con el cual este grupo se manejaba, el ámbito queer surge a modo de ruptura de las hegemonías establecidas desde cualquier perspectiva. El hecho, en la teoría, está bien demostrado y, de algún modo, se apela por su deconstrucción; sin embargo, en la práctica esto prevalece y es una de las prácticas más antiguas y tercas del sometimiento del individuo. Así, la idea de que, a pesar de estar "sujeto" a ciertas reglas y resultar víctima constante de la opresión, debe reproducirse el mismo modelo en el resto de los individuos que pueden estar bajo cierta demarcación de poder. Pero con esto no pretende decirse que la víctima se transforma en yugo de forma consciente, sino que se trata de un proceso subrepticio y absolutamente demoledor bajo el cual opera uno de los vericuetos del poder. El "vínculo apasionado", tal como lo llama Judith Butler, es una regla tan arduamente acicalada y entrometida en la mente de los individuos que, a pesar de su posible dolor, es muy difícil sobreponerse y mucho más eliminarla. A este respecto, las hermanas de Francisco no son personajes "culpables" necesariamente por la sanción operada sobre éste: de modo irremediable, están retransmitiendo y reproduciendo los modelos de conducta aprendidos. La norma queda así fijada drástica y duramente en la mentalidad de ambas y, de modo directo, el hermano ha aprehendido también dichos valores conductuales al grado de travestirse en un espacio como lo es de la alcoba, cerrado a cualquier intromisión que pudiera descubrir el acto del cual el personaje irremisiblemente se siente culpable. 
En el caso de Francisco entonces la norma está interiorizada desde el mismo momento en el cual advierte que su travestimiento sería algo impensable para la cosmovisión tenida por parte de su familia, en particular, y por el pueblo, en general. Nuevamente, el concepto de la "lógica del ocultamiento" planteado por Monsiváis, y anotado ya en el primer apartado de este trabajo, genera un situación soterrada con respecto a la visión que el personaje tiene de sí mismo; es decir que Francisco mantiene una imagen plagada de “automarginación" sobre su persona, lo cual le impide una realización de su sexualidad de forma placentera y, estaría de más pedirlo, abierta.

Otro factor muy importante en el tratamiento dado por el narrador a la coyuntura homoerótica consiste en el énfasis puesto respecto del color de piel, tanto de Francisco como de Nepomuceno. En el primer caso, se alude a la caracterización como mulato, la cual, hasta cierto punto, puede prestarse a la ambigüedad, debido a que dicho concepto puede constreñir un significado con la capacidad de aludir a un tono de piel blanco, mestizo u oscuro, aunque, sin duda, el hecho más importante de este rasgo sería el ser hijo de individuos que forman una oposición en cuanto al tono de su piel. Lo que sí queda más claro es el hecho de marcar la diferencia con respecto a Nepomuceno, quien es descrito por el narrador como un personaje de piel oscura. De este modo, el travestimiento de Francisco alude a una vieja y arraigada cosmovisión sobre la disidencia sexual, la cual dicta que el sujeto "activo" posee una coloración más oscura, mientras que el sujeto "pasivo" tiene a abrigar un tono más claro. Esta circunstancia ha sido reiterada ya en la literatura mexicana de tema homoerótico, junto con la también añeja concepción de que el sujeto "activo" debe poseer una mayor edad con respecto al "pasivo". No debe olvidarse aquí que buena parte de esta cosmovisión, heredada de la Grecia y la Roma clásicas, es un punto de encuentro con la concepción de las relaciones de pareja heterosexuales. Irremediablemente, la sexualidad disidente toma como base un 
aspecto "normativo" para su fundamentación, como ocurre con el advenimiento del matrimonio gay en las sociedades occidentales.

Por último, queda aclarar un punto sobre "Los Malabé" cuya base está dada por la propia articulación del pueblo. Grosso modo, el presente texto trae a colación una emblemática novela de tema queer en Latinoamérica: El lugar sin límites de José Donoso, donde la presencia de la homosexualidad está determinada por las relaciones creadas entre el protagonista, La Manuela, y el resto de los habitantes del pueblo. Así, este pequeño espacio se convierte en un microuniverso queer que ejemplifica bastante bien las manifestaciones del deseo y su proscripción o libertad. En el caso de "Los Malabé" la cuestión es similar en cuanto a la estructura presentada, pero absolutamente contraria a los valores esbozados; aunque el cuento es muy breve y apenas se menciona algunos rasgos, negativos en su mayoría, sobre el sitio en donde habita Francisco, con ello es suficiente advertir los modelos de conducta que, de algún modo, parece oponerse. En primer lugar, destaca la carga moral llevada a cabo por las hermanas y, en general, la familia Malabert; sin embargo, destaca la presencia del negro Nepomuceno como un ser bastante ambiguo en cuanto a su sexualidad se refiere. En las primeras páginas del cuento, el narrador, Felipe, destaca cómo Francisco le otorga el descuento sobre el precio del café a partir de observar, a lo lejos, cómo Nepomuceno ${ }^{219}$ regresa del mar: "Don Francisco Malabert se inclinó, sacando la cabeza del círculo de sombra, y lanzó toda su mirada hacia la embarcación. Sus ojos no pestañearon hasta que el runrún no se detuvo en el desembarcadero; y un negro joven, en pantalón de

\footnotetext{
${ }^{219}$ La cita que se muestra no señala directamente a Nepomuceno, más resulta muy fácil advertir que se trata de él debido a que, en el párrafo anterior, el narrador afirma la entrada de una lancha a motor en el pequeño puerto. Esta liga se establece con base en el relato pronunciado por el negro al final del cuento, según el cual Francisco, a cambio de ciertos favores sexuales, le otorga la lancha como medio de pago por dichas acciones.
} 
baño, saltó a tierra, amarró la lancha y entro en una caseta. Don Francisco recogió su mirada, suspiró y dijo: -Muy bien, don Felipe, tendrán ustedes la rebaja”. ${ }^{220}$ Esto suceso es un guiño de la analepsis enunciada al final del cuento, en la que Nepomuceno confía al narrador su encuentro con Francisco. Por tanto, esta ambigüedad sexual en cuanto a la conformación de la identidad del negro, lleva al lector a pensar en una posible libertad en algunos de los integrantes del pueblo. Nepomuceno, en este caso, adquiere entonces un revestimiento muy cercano a la prostitución y, además, se advierte en él una suerte de bisexualidad llevada a un término más libertario que enclaustrante.

${ }^{220}$ De la Colina, pp. 48-49. 
Consolidación (1961-1990)

El primero de los cuentos trabajados en este apartado, "Los amigos" (1962) de Juan Vicente Melo, posee un discurso bastante complejo, creado a partir de una serie de alteraciones en el tiempo y un lenguaje ornamentado, características que, está de más decir, son propias del autor y de su exquisita narrativa. León Guillermo Gutiérrez menciona lo siguiente al respecto de este relato: "En una prosa ágil, elegante y de extraordinaria riqueza verbal, las acciones avanzan, se detienen, retroceden, se repiten, en una estructura narrativa que apela a un lector que reconstruya la fragmentación de acciones, tiempos y espacios". Y, efectivamente, "Los amigos" necesita, como bien lo menciona el crítico, de este tipo de lector con la capacidad y el deseo de recuperar los sucesos ocurridos.

Contado desde un narrador heterodiegético y con un uso abundante del estilo indirecto libre, "Los amigos" es el devenir de una historia poco convencional que permanece en un ámbito de sutileza. En consecuencia, el lector debe ir más allá de una primera impresión para poder hallar la orientación, tanto discursiva como diegética, del texto en cuestión. Y es que, para la fecha de publicación y aún ahora, no se trata, para nada, de un texto sencillo: si Melo crea una estructura rica y, a la vez, maravillosamente ambigua, en la historia provoca una serie de sensaciones cuya representación, en apariencia, se mueve en un plano confuso. Así, con la frecuencia repetitiva tan usada a lo largo de los relatos que conforman Los muros enemigos, el autor pone al alcance del lector la relación entre dos "amigos" con ciertas "complicaciones" al momento de definir aquello que los une. 
Enrique y Andrés, los dos protagonistas del cuento, crean un acercamiento con rasgos tales que sumerge al lector en un abismo en cuanto al deseo de encontrar una respuesta factible a lo observado. Y realmente esta situación no es gratuita, por lo contrario, pareciera que Melo pretende brindar una perspectiva vaga para una historia enigmática también, sobre todo en cuanto a cuestiones morales y sociales se refiere. Cabe recordar aquí que los cinco textos integrantes de Los muros enemigos proponen una visión poco ortodoxa del amor y sus implicaciones. Al respecto, Alfredo Pavón dice: "Melo crea [...] una cuentística del pordiosero amor, ese que se percibe, tenuemente, detrás de magra mueca, pronta a convertirse en infecta herida". ${ }^{221}$ Sin embargo, esta "infecta herida" es, en realidad, una vuelta de tuerca para todos aquellos preceptos hegemónicos o directrices colectivos de la vida del hombre. Los cuentos ofrecen un punto de vista individual con incertidumbres y rupturas con respecto al plano de lo colectivo: la fractura de un matrimonio imaginado como indivisible, la masturbación al centro de la vida de un hombre destacado y valorado por su entorno, el deseo de venganza e incesto, así como la negación de la familia en sus bases más sensibles constituyen, junto con el plano del homoerotismo subyacente en "Los amigos", una bofetada a cualquier discurso que pretenda colocar restricciones a la vida del individuo o, si se lo prefiere, a los efectos lastimeros y destructivos de dicho artilugio.

La historia del cuento entonces oscila entre los ámbitos de lo aceptable y lo punible. Desde el principio, el cuento hace uso de forma extraordinaria del "sentimiento de culpa" que puede emerger de los dos protagonistas. Con dicha concepción, Enrique y Andrés establecen su vida diaria y, como bien lo señala el cuento, la propia muerte que, en ciertos casos, no necesariamente ocurre en el aspecto físico, sino en el propio vacío, agotamiento o

\footnotetext{
221 Alfredo Pavón, "Cuentística del pordiosero amor", en Juan Vicente Melo, Los muros enemigos (Xalapa: Universidad Veracruzana, 2007), p. 9.
} 
inhibición del propio deseo. De este modo, el cuento de Melo relata la relación entre dos "hombres" que se conocen por casualidad y asumen cierta proximidad homoerótica con base en un plano homosocial:

En "Los amigos", las afinidades emotivas y estéticas posibilitan el nacimiento del amor en Andrés y Enrique, pero no bastan para fundar definitivamente la caricia y el diseño de los venturosos días por venir. Enrique, el seducido, acepta la tentación homosexual, pero jamás desafiará el orden heterosexual en el cual ha vivido. Esta dualidad lo obliga a vivir en el desasosiego, que se eternizará en su interior, intensificándose a partir de la muerte de Andrés. Desde este doloroso deceso buscará reconstruir su vida anterior, si bien terminará por asumir que es ya el portador del mal y la vergüenza, como lo indican su continuo roer los instantes compartidos con Andrés; el obligado tránsito por calles, cafés, bares, salas de concierto; el retorno a los objetos, ruidos, olores y seres que constituirá el microunvierso de su amigo. El amor culpable es su condena, el círculo nefando en el cual habrá de revivir por siempre su incapacidad para entregarse al otro, para recorrer las otras veredas de la pasión. ${ }^{222}$

La construcción de la identidad en el cuento es realizada por el narrador a partir de esta perspectiva sobre la culpa, que no permite el desarrollo del plano afectivo, más bien lo destroza. Como bien es sabido, en la sociedad mexicana cualquier deseo alternativo a lo considerado "oficial" es considerado una infracción a los valores de la misma. El infractor, por tanto, posee una idea de lo adecuado y lo perverso a partir de este filtro que permite observar a la sociedad. Una vez atravesada la frágil frontera entre estos dos ámbitos, la culpa, a pesar de las posibles libertades, tanto de cuerpo como de mente, poseídas por el individuo, se presenta y permea consuetudinariamente el quehacer del individuo.

222 Pavón, pp. 12-13. 
La frecuencia repetitiva sirve a este respecto para crear un efecto en el cual los sucesos están en un recuerdo constante y, por tanto, en un retorno interminable: las acciones, a pesar de haber sucedido ya en el pasado, no dejan en paz a Enrique y lo acorralan a cada momento. Así, la presencia de Andrés se torna interminable; sin embargo, este efecto no necesariamente está creado por la culpa, sino por la sensación afectiva o atracción sexual: “Junto a Andrés, la ciudad era otra: hermosa, tranquila, con luces y cines y ventanas abiertas y personas que caminaba como ellos, frente a ellos o a su lado, sonrientes y despreocupadas". ${ }^{223}$ Como se observa, la mezcla de la culpa con la necesidad del "otro" se convierte en una tortura constante que, posiblemente, sólo termine con la muerte del propio Enrique.

Esta dualidad en el revestimiento del personaje permite interpretar la perspectiva abyecta tenida sobre una sexualidad disidente: Enrique representaría el aspecto del deseo que se pretende alcanzar y el flagelo producido por este mismo tránsito. La "construcción” de la homosexualidad aparece así bien delimitada, desde la perspectiva intrínseca del personaje y desde su relación con los diferentes aspectos hegemónicos de la sociedad donde se habita. Mauricio List Reyes señala, con base en la concepción del sistema sexo/género planteado por Gayle Rubin, cómo "esta normatividad pone en la cúspide del orden social a los individuos heterosexuales, monógamos y reproductores, y a partir de allí, en orden descendente, se encuentran todas aquellas prácticas que no siguen ese modelo". ${ }^{224}$ En este caso, el personaje se asume con una representación "prestigiada" que, tomando en cuenta la linealidad sexo/género/deseo desarrollada por Butler, correspondería a un varón, masculino y heterosexual: sin embargo, en la práctica este "orden" sufre un atentado por las implicaciones llevadas a cabo por el flirteo homoerótico.

\footnotetext{
${ }^{223}$ Melo, p. 55.

${ }^{224}$ Mauricio List Reyes, Jóvenes coraz̧ones gay en la Ciudad de México (Puebla: BUAP, 2005), p. 29.
} 
La obsesión de Enrique está constituida pues por la negación del posible deseo hacia Andrés y, paradójicamente, por el continuo recordatorio del personaje. Desde que el relato inicia, Enrique recuerda la presencia de su "amigo" mediante un sonido estridente: "A lo lejos, sonó el largo y agudo silbido de una ambulancia. Andrés siempre le decía que las ambulancias le daban miedo". ${ }^{225}$ Más adelante, el recorrido hecho por Enrique a lo largo de los sitios familiares de la ciudad trae a colación la presencia de Andrés de forma inmediata. Entre dichos lugares destaca, por razones obvias, la casa de este último: "Lo único indestructible en la ciudad era el edificio donde vivía Andrés. Todo lo demás, incluso muchas casas de ese barrio tan tranquilo, alejado de las llamabas zonas residenciales, cambiaba, desaparecía". ${ }^{226} \mathrm{El}$ espacio entonces adquiere un impulso vital en el relato al ser asumido por Enrique no sólo como su hábitat, sino como una suerte de autobiografía constante en la cual destaca la relación soterrada y abyecta, pero profundamente afectiva y, sin duda, placentera. Así, el cuento se convierte en un mapa develado a través de la historia y viceversa: ambos polos están intrínsecamente implicados al grado de apuntar hacia el mismo punto, el recuerdo de Andrés.

El recorrido de Enrique es recreado desde el principio con esta capacidad memoriosa, que trae a colación el encuentro con el "amigo". A lo largo de las páginas, el lector presencia, de modo fragmentario claro está, el encuentro entre ambos personajes, el desarrollo de la proximidad y las complicaciones de la misma:

No cansarse de observar la calle o de imaginar colinas y prados, mar verde azul, verde negro, tranquilo, furioso mar. Hacer un orden: primero mirar el florero, las máscaras una por una, los libros, los discos y

\footnotetext{
225 Melo, p. 51.

226 Idem, p. 52.
} 
luego las cosas grandes: cama, ropero, ventana. Contar hasta cien y empezar de nuevo, encender un cigarro, oír la señal, repetirse que no, que no vendrán a buscarlo, que nadie le preguntará nada, que se conocieron hace tres meses (tal vez cuatro) en una fiesta, que Andrés estaba ahí, aburrido, en un rincón, que le sonrió y que al pasar le dijo, como si nada “ven, vámonos”, y que caminaron, que le preguntó “¿en qué ciudad te gustaría vivir?” y, antes de que contestar algo, que le había respondido como si hablara solo "a mí en ésta, ¿sabes?, porque es la única en el mundo donde podría encontrar a Dios”, y que le dijo que lo esperaba al día siguiente y que se vieron todas las noches a las ocho y media, que tenían una señal -el andantino de la sonata en sol menor de Schumann- y que nunca lo invitó a subir a su cuarto. Todo, menos preguntarse "por qué". Hasta dejar de oír la señal y cambiar a la estación de radio que marca la hora: las tres y veintidós, las cinco y cincuenta, las ocho y media.

Cabe destacar de esta cita cómo inicia casualmente la amistad entre los dos personajes y, paulatinamente, se va transformando en un hecho más cercano a una relación amorosa. Desde el momento en el cual Andrés le pregunta a Enrique en qué ciudad le gustaría vivir el contacto es más cercano e íntimo. Además, esta pregunta es reiterada a lo largo del cuento y propone lo que ya se había mencionado páginas atrás: la ciudad como reveladora y recordatorio de la historia del texto. Por otro lado, están las citas recurrentes en las que la construcción del lazo afectivo estará presente y la señal del llamado entre ambos: la música de Schumann. Igualmente, destaca el hecho de la afirmación de que Andrés no invitó jamás a Enrique a subir al cuarto del primero, así como la presencia del tiempo y su ineludible capacidad de transformar los hechos o, en cierta medida, colocarlos nuevamente en el espacio a través de la memoria o la invención provocada por la misma.

No obstante, esta cita, a pesar de que deja entrever la relación tendida entre los dos personajes, está dicha en un tono de mentira: Andrés ha aparecido muerto en su alcoba y Enrique imagina que la policía debe estar haciendo las pesquisas correspondientes, entre las 
cuales estaría el interrogarlo para obtener ciertos indicios sobre el crimen; por tanto, la información provista en este nivel es una máscara sobre los verdaderos hechos acaecidos.

Salta a la vista del lector nuevamente la dualidad del personaje, quien lucha entre una posible representación adecuada y otra objeto de escarnio. Esta circunstancia es muy simbólica en cuanto a la construcción realizada, por parte del aparato de poder, sobre el individuo. Sobre esta situación, Judith Butler menciona que el dispositivo del poder crea en el individuo un sometimiento expresado en dos niveles: desde el plano mismo del poder, con la formación de su régimen, y con la aceptación, por parte del ser humano, de su sujeción. En el caso de Enrique estos dos bastiones están formulados de un forma clara y, en algunas ocasiones, alegórica. En primer lugar, el revestimiento de la hegemonía está dado por el mismo imperativo de la sociedad heterosexual en la cual está inscrito el personaje; además, en esta misma línea, el aparato policiaco que podría indagar al respecto de la muerte de Andrés está operando en Enrique una suerte de castigo a través de la conciencia. Con esto se quiere decir que, desde una instancia externa, se crea una normatividad tan amplia con la apelación directa al estatuto social: el personaje entra en esta dialéctica sin darse cuenta y, con base en la observación del exterior y la reglamentación emanada del mismo, se crea en su interior un rechazo hacia lo que el propio aparato del poder niega o construye de forma peyorativa. $^{227}$

Por estas razones, el lector advierte en el cuento una lucha incesante en ambos personajes: "El poder que opera en el sometimiento se manifiesta, por tanto, en dos modalidades temporales sin común medida entre sí: en primer lugar, como algo que es

\footnotetext{
${ }^{227}$ Si bien la policía podría buscar a Enrique por la amistad existente entre ellos y con el fin de averiguar sobre las causas del suicidio, en realidad el personaje observa al aparato policiaco desde una perspectiva más relacionada con la sanción social. En otras palabras: más que temer un involucramiento directo con la muerte de Andrés, Enrique podría temer el descubrimiento de la relación afectiva entre ambos.
} 
siempre anterior al sujeto, está fuera de él en funcionamiento desde el principio; en segundo lugar, como efecto voluntario del sujeto [...] el sometimiento es una subordinación que el sujeto se provoca a sí mismo". ${ }^{228}$ Las reglas externas se asumen de tal forma en la cosmovisión del hombre que se asume como algo inamovible y existente desde siempre; además, produce la impresión de que todo lo normado es natural por su misma capacidad de dominación. La conducta de Enrique está sometida a una serie de reglas que, desde su propia perspectiva y la social, es imposible de modificar; por otro lado, si esto último llega a suceder el castigo es algo inevitable. Así, en "Los amigos" el efecto punible está dado desde el propio personaje, quien no asume las diferentes posibilidades de una sexualidad diversa y, por tanto, las rechaza, aunque en ese rechazo esté coartando su propia libertad o destruyéndose. Por estas mismas razones, la obsesión por contrarrestar la "disidencia sexual" con una mascarada heterosexual favorece, muy cerca del final del texto, la contemplación de la culpa y la resistencia a caer en lo prohibido. Aquí aparece Antonio, un tercer personaje y amigo de Enrique, con el cual el protagonista acude a un bar y mantiene, en una ocasión, un encuentro sexual con una prostituta. Igualmente, en este punto, el narrador retrata con fidelidad los posibles eventos con los que puede llevarse a cabo la identificación con lo masculino: "Volver a ver a Antonio caminando a su encuentro, saludándole, diciéndole: 'Bueno, ¿nos portamos como caballeros o como lo que somos?', y tomarlo del brazo, saltar con él, decir tonterías a las mujeres, asustar a las niñas, subirse en un taxi colectivo y hablar de cosas terribles". ${ }^{229}$ Los dos personajes determinan aquí los procesos mediante los que se construye colectivamente una masculinidad en la etapa de la adolescencia. A su vez, este hecho

\footnotetext{
${ }^{228}$ Judith Butler, Mecanismos psíquicos del poder, p. 25.

${ }^{229}$ Melo, p. 60.
} 
constituye una demostración de una "partida doble" jugada por Enrique, quien posee un deseo "negado" y propone entonces un discurso hegemónico para cubrirlo.

Ahora bien, y desde la otra perspectiva, es decir la relacionada con la eclosión "pura" del homoerotismo, el narrador describe las diversas sensaciones que el cuerpo del "amigo" produce en Enrique:

Sentía el brazo de Andrés apretando el suyo, el pecho subiendo y bajando con calma, el calor obediente al ritmo de la respiración. El aire se llenaba de la presencia de ellos, de un momento distinto, un chasquido de la lengua, un alzar de hombros o una risa que no tenía antes el aire. Les gustaba mirar sus dos sombras desproporcionadas, alagarlas o empequeñecerlas cuando aceleraban el paso o lo retenían en otro más calculado. Iban a un café, a un cine, a un concierto. Se contaban lo que habían hecho durante el día, los libros leídos, el curso de sus estudios; a veces, comprendían el valor y el significado de sus silencios, de sus frases inconclusas, de los ademanes que implicaban algún sobreentendido. Y entonces caminaban callados hasta que Andrés decía, de pronto, algo que no tenía nada que ver con lo que se habían dicho antes y todo tomaba un aspecto insólito. Se despedían junto a la reja oxidada y cuando se iluminaba el pequeño rectángulo del tercer piso, Enrique regresaba a su casa. El día terminaba con un leve desasosiego pero todo comenzaría mañana, a las ocho y media. ${ }^{230}$

Esta cita es profundamente hermosa y clara con respecto a la relación tendida entre los dos personajes. Además, enfrentada con el fragmento anterior, en el cual Enrique trataba de dar una impresión "diferente" a la policía sobre su cercanía con Andrés, hay una afirmación concreta del deseo homoerótico. En primer término, el contacto con el cuerpo del otro marca un hecho placentero e inicia una empatía entre ambos, seguida de un señalamiento a la idea de la diversidad con la acotación del "momento distinto". El narrador ofrece entonces un

\footnotetext{
${ }^{230}$ Melo, p. 56.
} 
panorama de lo que es ahora el espacio habitado por Enrique y Andrés, quienes lo miran con la certeza de que, su cercanía, le imprime características más afables y, en cierto modo, lo hacen suyo. Esto es entendible con el recorrido realizado a por Enrique a lo largo de su cuadra y la ciudad, impregnada, para él, de la presencia ineludible de Andrés. En segundo lugar, destaca el hecho de observar sus sombras, como si advirtieran en ellas un afecto inusitado, proyectado sobre el suelo cómplice de su "unión". Por otro lado, aparte de la mención de la complacencia creada entre ambos personajes a partir de su deambular por la calle, existen guiños incuestionables sobre una "relación de pareja". En este punto, el narrador pretende equiparar la proximidad con otras proximidades, es decir que el flirteo puede ocurrir del mismo modo en el cual podría suceder en un ámbito heterosexual. Así, el observar a los personajes despedirse sobre la reja, mientras Andrés sube a su habitación y Enrique retorna a su hogar, implica toda una tradición relacionada con el romance y las escenas más típicas del mismo. Con esto, si al final del cuento Enrique prefiere dormir para no recordar lo sucedido, en este pasaje el sueño es una espera afortunada si, al día siguiente, se reanudaba el idilio.

La astucia narrativa de Melo al elaborar el relato queda explícita en la contienda entre los dos polos sufridos por el personaje. El deseo y el rechazo del mismo son las dos caras de una moneda dolorosa, en la cual el habitus mantiene una ganancia y actividad punible sobre el sujeto determinado. A la par del encuentro y la posibilidad del desencuentro entre Enrique y Andrés, existe otra celada en la cual el narrador hace un gran hincapié. Ésta consiste en los posibles regalos que Enrique ofrece a su "amigo". Estos elementos, al igual que la presencia de la ciudad, son un leitmotiv con los cuales el cuento llega a su efecto adecuado. Así, pocos días antes de la muerte de Andrés, Enrique trata de brindarle al primero un disco y una máscara, los cuales no son aceptados. Este hecho marca el recuerdo de Enrique al respecto 
de la relación y, de la misma forma, generan ambigüedad en la historia. No obstante, para dilucidar esta situación, es preciso asentar que el relato posee una estructura temporal en la cual hay dos tiempos: el presente de Enrique y su pasado, contra el que se enfrenta a partir de la memoria; a su vez, como ya se ha mencionado a lo largo de este estudio, existen diversos puentes, sobre todo la presencia de la ciudad, con los cuales Enrique se conecta con la historia eludida. El disco y la máscara se suman a este recurso y, además, edifican una alegoría en torno la relación homoerótica: si bien Andrés rechaza los obsequios de Enrique, estos permanecen en la habitación de este último y se transforman en un resorte narrativo. Por otro lado, son, para dicho personaje, una afirmación de su "inocencia" con respecto a la muerte de Andrés, ya que al no ser aceptados plantean una ausencia del delito. Aquí ocurre una doble situación alegórica: 1) la ausencia de los objetos en la habitación de Andrés implica una negación de la relación tenida con él, por tanto, el efecto del poder crea en el sujeto un rechazo de aquel pasado idílico y el objeto de su deseo; 2) el disco y la máscara condensan, por si fuera poco, una nueva dualidad, en la cual la primera cosa determina el encuentro entre los personajes -recuérdese aquí que ambos se comunicaban el inicio de su cercanía con la sonata en sol menor de Schumann-y, la segunda, una vuelta de tuerca con respecto a la hegemonía de una "matriz heterosexual" y las identidades, prestigiadas y marginadas, emanadas de la misma. ${ }^{231}$ Como se observa, un mismo objeto puede ser el receptáculo de las dos posturas planteadas en el cuento y sirve, potencialmente, para ser equiparado con la figura del personaje. Esto último convoca la figura de la sinécdoque, mediante la cual el lector podría

\footnotetext{
${ }^{231}$ Este ardid de la máscara trae a colación, sin duda, el cuento de Amado Nervo, "Aventura de carnaval". Como ya fue dicho en el capítulo "Antecedentes", este texto señalaba las posibilidades de la construcción de la identidad del sujeto con base en la máscara usada por el personaje travestido, la cual le sirvió para seducir a su primo. Igualmente, la idea del disfraz, así como diversas prendas de vestir aludidas en otros cuentos estudiados en este trabajo, son símbolos innegables de la puesta en tela de juicio de las identidades y el deseo convocadas por un babitus determinado
} 
suponer que el disco y la máscara estarían en lugar de Enrique, y representarían los conflictos enfrentados por la asimilación de la heteronormatividad y, al mismo tiempo, la incidencia del deseo homoerótico.

El ámbito de lo marginal convocado en "Los amigos" crea una idea muy concreta de la visión tenida al respecto de la sexualidad por parte de la sociedad mexicana de principios de la década de los sesenta. Además, la presencia de la muerte de Enrique refuerza el lazo de la disidencia sexual con la destrucción del individuo que la posee. Esto puede relacionarse con la idea planteada por Michel Foucault al respecto de que el estado es capaz de proporcionar vida y, al mismo tiempo, dosificar la muerte. La sociedad mexicana crea entonces una visión abyecta de aquello mantenido al margen con el fin de destruirlo. Igualmente, todo aquello con un revestimiento negativo siempre "existe" para con el fin de reflejar en él los valores "positivos". Por estas razones, es obvio que en "Los amigos" la alusión a la heterosexualidad sea directa, mientras que las diversas manifestaciones del deseo homoerótico son subrepticias. Además, todo aquello colocado en una situación periférica conlleva el camino de la "muerte" desde el mismo acontecimiento de su personificación: lo "abyecto" no puede realizarse a menos que sea para reforzar la factibilidad de lo ortodoxo y mostrar cómo en su propio revestimiento está la posibilidad de la desaparición.

La muerte en el cuento de Melo "asegura" la eventual "superioridad" de lo normativo; sin embargo, esta muerte es, en buena medida, alegórica en cuanto que no representa estrictamente el fallecimiento de Andrés, sino de todos aquellos en la misma postura. Pero deberá irse por partes para poder explicar con precaución este asunto. La historia del texto plantea que, después de los tres meses de "amistad" entre los dos protagonistas, Andrés aparece muerto en su habitación y todo apunta a la ejecución de un suicidio. El hecho está definido por la misma negación del deseo homoerótico prevaleciente en el texto, a pesar del 
abigarramiento de dicha pasión en ambos personajes. Así, una autodestrucción es factible por los recursos tan insidiosos del dispositivo de la sexualidad: "Los discursos que nos oprimen muy en particular a las lesbianas, mujeres y a los hombres homosexuales dan por sentado que lo que funda la sociedad, cualquier sociedad, es la heterosexualidad". ${ }^{232}$ Teniendo a este axioma frente así, el sujeto disidente no tiene otro camino que la desaparición, sea simbólica o física, y, lamentablemente, en el caso del cuento operan las dos: si la muerte de Andrés es pensada como suicidio, la hipótesis desencadena una revisión por un proceso por el cual el personaje se "automargina" al grado de proporcionarse la muerte; además, aunque esta muerte está dada por una condición intrínseca, la "causa de la causa" está centrada en la heteronormatividad y el patriarcado hegemónico. ${ }^{233}$

Cuando Enrique descubre esta noticia dos días atrás del punto de partida del relato, su estupefacción es tal que, llegado el tercer día, deambula por la ciudad en busca de aquellos indicios con el suficiente poder para acercarlo a la presencia/ausencia de Andrés. La separación entre los dos personajes y el finiquito de su relación afectiva plantea una perspectiva de la "homosexualidad trágica" para el cuento. La destrucción del "ambiente homoerótico" es, siempre, la contrapartida de la hegemonía heterosexual y representa el agente demoledor inscrito detrás de la misma. ${ }^{234}$ Algunos de los cuentos estudiados en este

\footnotetext{
232 Wittig, p. 35.

233 Actualmente, el concepto de crímenes de odio está dado para designar aquellos homicidios en los cuales la causa es la conducta sexual o identidad de la víctima; no obstante, otra cara de dicha práctica bien podría ser el suicidio por considerarse un individuo al margen de la sociedad que se habita aquel que lo comete.

${ }^{234}$ En este sentido, Ricardo Llamas menciona: "El distanciamiento último a que se enfrenta "la homosexualidad' es el establecido con respecto al derecho de aspirar a la felicidad o el bienestar. Un derecho reconocido como legítimo 'en general' (esto es, con ciertas excepciones). Siendo éstos los ideales a los que aspira la comunidad legítimamente establecida, y situándose 'la homosexualidad' fuera y lejos de ésta, lo que se producen entonces una localización de 'la homosexualidad' en la tristeza, en el dolor, en la enfermedad y, sobre todo, en la muerte. A partir del siglo XIX y de manera progresiva, se establece una asimilación entre 'la homosexualidad' y el dolor; una confusión del origen del sufrimiento con la esencia de quien sufre. De este modo, al atribuir el dolor a 'la homosexualidad' como elemento intrínseco
} 
trabajo, como lo serían "Los machos cabríos" de Jorge Ferretis y "Los Malabé” de José de la Colina, exhiben, al igual que "Los amigos" un discurso social profundamente contestatario desde un plano simbólico que afecta notablemente la vida de los personajes. En el caso de los textos de Ferretis y de la Colina, esta afectación es en un grado mucho menor, puesto que el cuento de Melo alberga la muerte como el único camino punitivo para la víctima del dispositivo de la sexualidad. ${ }^{235}$

Por otro lado, la destrucción planteada no sólo está relacionada con la desaparición de Andrés, Enrique es quien sufre también los desastres del acontecimiento fatídico al deambular en un espacio en continua transformación que, paradójicamente, le recuerda a cada instante la presencia de su amigo y el fervor tenido hacia él. Esto está en vinculación directa con el epígrafe de Octavio Paz: “Toda la noche batalló con la noche”. En una primera acepción, puede mencionarse que esta lucha estaría representada por el deseo establecido entre los dos personajes; sin embargo, este suceso presenta una grave diatriba con la fortaleza suficiente para mantenerlo en entredicho. Por otro lado, en un plano mucho más amplio, el deseo no estaría constreñido únicamente a los dos personajes de "Los amigos", sino a toda una convención en la cual se combate entre aquello que debe representarse y lo que se es o desea. El problema de la identidad salta a la vista, y es claramente reforzado con la posible "masculinización" del personaje al lado de Antonio. Así, el conflicto de lo asumido como

de ésta, el régimen de la sexualidad logra que los mecanismos por los que esa atribución se recrea constante pasen desapercibidos". Ricardo Llamas, Teoría torcida. Prejuicios y discursos en torno a "la homosexualidad" (Madrid: Siglo XXI, 1998), p. 143.

235 Claro está que esta perspectiva es dada para mostrar los recalcitrantes resultados de una hermética sociedad con respecto a las "libertades sexuales", y el tono alegórico en el plano discursivo es el ejemplo más pertinente para sostenerla; además, como se dijo con anterioridad, Los muros enemigos es un volumen con un deseo inextinguible de explorar los vericuetos hacia los cuales son arrojados los individuos no "sujetados" a un paradigma de la sexualidad instaurada. 
representativo del hombre ingresa a una constante disputa arquetípica de condiciones ontológicas o, como diría Butler, la norma produce sujetos y los hace pensar que la existencia de la misma es anterior a su propia naturaleza.

A diferencia del final desafortunado y trágico en el caso de "Los amigos", el cuento de Jorge López Páez, "Doña Herlinda y su hijo" (1980), posee un desenlace muy satisfactorio para los personajes en relación con el tema de la "disidencia sexual". Innegablemente, el texto de López Páez ha servido de mucho al ámbito de la literatura y el cine mexicanos de tema homoerótico. En el primer ámbito, el texto es emblemático por la afirmación de la "homosexualidad" en dicho rubro y ha sido uno de los más citados al hablar del tópico en la cuentística nacional. Por otro lado, con base en la historia del relato de López Páez, el director Jaime Humberto Hermosillo realizó una de las películas más aclamadas y mencionadas sobre la cuestión de la "disidencia sexual". Este último tema ya fue tratado con mayor amplitud en el primer capítulo del presente trabajo, así que, en este momento, la atención estará centrada únicamente en el cuento.

Si se hace una pequeña comparación en cuanto al estilo de los textos aquí estudiados, un comentario muy evidente es la gran diferencia en el estilo de los dos cuentos revisados en este capítulo: "Los amigos" posee una fragmentación en el ámbito temporal y lingüístico muy severa que afecta la percepción de la historia de forma directa; en cambio, "Doña Herlinda y su hijo" posee una narrativa más sencilla, podría decirse que lineal, con un lenguaje coloquial. Este hecho no implica ningún detrimento o superioridad de un texto sobre el otro; por lo contrario, cada uno de ellos, en su espacio estilístico posee rasgos notables que los dotan de distinción y calidad literaria.

En esta visión de un discurso mucho más paralelo con respecto a la historia -sobre todo en cuanto al recinto temporal se refiere-, "Doña Herlina y su hijo" posee un narrador 
autodiegético. El protagonista, Ramón, cuenta su propia historia in extremis a partir del recuerdo de los hechos más recientes de su existencia, es decir la compleja relación entre él, Rodolfo, doña Herlina y Olga.

En este proceso de traer a colación todos los eventos, Ramón proporciona al lector una inusual perspectiva con respecto a la familia y a la disidencia sexual. Al respecto de la primera esfera puede decirse que priva una visión muy heteróclita entre el ámbito de lo socialmente aceptado y lo vilipendiado. La pequeña familia formada por Rodolfo y doña Herlinda aparece, en un principio, como algo ajustado a una realidad mexicana muy intrínseca. El narrador no proporciona mayores datos, pero el lector puede suponer que doña Herlinda es viuda -un divorcio resulta mucho más difícil de imaginar por la misma astucia del personaje- $\mathrm{y}$, claro está, posee un nivel económico medio que le permite vivir con cierta comodidad. Su hijo, Rodolfo, es un joven médico muy apegado a la madre y con una obsesión perenne de cumplirle todos los caprichos deseados por ésta. La madre representa en este caso la visión sobre el elemento femenino en el espacio del parentesco, pero también, y de forma muy marcada en el cuento, asume las características de la figura patriarcal; en otras palabras, Doña Herlinda convoca - por necesidad y por gusto- el clásico binomio genérico en una misma representación. De este modo, la definición del núcleo familiar es "pertinente" y atañe a los valores más arraigados sobre su propia concepción a lo largo de la historia mexicana.

Es conveniente establecer también que el prototipo de familia mexicana siempre alude a la concepción de un núcleo, hasta cierto punto hermético, con la capacidad de "cubrir" a sus integrantes de una posible "anomalía" por parte del exterior, sobre todo en lo que se refiere a las cuestiones del género y la sexualidad. Al respecto de esto, Monsiváis menciona lo siguiente: 
¿En qué consiste y en dónde desemboca el ocultamiento o el aplastamiento de la vida sexual? En el origen del procesos está la Familia Mexicana, invención conjunta de la iglesia católica y las clases dominantes, cuyo ideal, la utopía del mando irrestricto del patriarcado, se transparenta en unas cuantas acciones: monogamia de aplicación unilateral (sólo para las mujeres), ocultamiento o negación del placer, uso político de las prohibiciones (y tolerancias) sexuales, elevación de la ignorancia al rango de la obediencia de la ley divina y de la ley social, represión enaltecida a nombre del deseo de una mayoría jamás consultada al respecto. Históricamente, la mitología de la Familia Mexicana se centra en la necesidad de proclamar ajeno y enemigo a lo que ocurre fuera del recinto hogareño y del control de esa policía perfecta que es la conciencia de culpa. Y esta moral exige varios movimientos paralelos: el desarrollo de una idea de Nación similar al patriarcado, el odio (retórico y real) a lo diferente, la manipulación de los prejuicios. ${ }^{236}$

Los diferentes axiomas planteados por el ensayista al respecto de la familia mexicana resultan aceptables y paradójicos en el caso del cuento de López Páez. Como se mencionó, doña Herlinda es una mujer que asume un doble rol en cuanto a su representación de género en el ámbito social y al interior de su propio núcleo familiar, en este caso, aunque su revestimiento corresponde al ámbito de lo femenino, ostenta un poder absoluto y una figura patriarcal incuestionable. ${ }^{237}$ Esto puede ser corroborado con la información proporcionada por el narrador, Ramón, quien antes de integrarse a la familia de Rodolfo sufre ya los embates de la dominación de la matriarca: "Y en ese momento quisiera ser preciso y explicar cómo me dijo doña Herlinda que yo no debería de bailar en el lugar donde nos dirigíamos, sino acompañarla, porque de otro modo se emborracharía Rodolfo y al día siguiente no iba a

236 Carlos Monsiváis, Que se abra esa puerta, p. 211.

237 Para ejemplificar esto, baste anotar el siguiente pasaje en el cual Ramón alude al empoderamiento del personaje señalado: "Es innecesario que declare que dondequiera que ella se sentaba se convertía en la silla principal”. López Páez, p. 34. 
operar bien, y que así era mejor para todos". ${ }^{238}$ El poder ejercido por parte de doña Herlinda parece acaparar entonces todo aquello que pudiera rodearla, aunque se tratara de individuos "ajenos".

El control del personaje sobre la situación planteada en la historia resulta avasallador y, en cierto modo, inexplicable. Como es bien sabido, la diégesis del cuento consiste en la serie de acontecimientos realizados por doña Herlinda para sostener la felicidad y la identidad de género de su hijo: el primer punto estaría representado por la relación homosexual con Ramón y, el segundo, con el matrimonio con Olga. Estos sucesos están tan bien estudiados por doña Herlinda que articula un plan muy bien delimitado y admirable para congraciar ambas situaciones en una misma casa, sede del poder y control familiar establecido por el propio personaje en cuestión. Hasta aquí, el tema de la dominación coincidiría con lo dicho por Monsiváis en torno al tema de la familia mexicana como una estructura de poder y capaz de mantener en la obediencia a cada uno de sus miembros.

Ahora bien, en el punto mencionado por el ensayista citado sobre cómo la familia mexicana es un gigantesco bastión en contra de todo aquello que pueda corromper, en el ámbito del género y la sexualidad, a sus miembros queda, en el cuento, soslayado y, a la vez, bien concretado. Si la familia es el depositario de las "buenas costumbres", belicoso guardián de la heteronormatividad y el patriarcado, ¿cómo puede explicarse la conducta de doña Herlinda? ¿Cuáles son los motivos que pudieran llevarla a aceptar -o imponer- la presencia de las dos parejas de su hijo, la "masculina" y la "femenina" en el mismo recinto de la casa familiar? La principal respuesta que puede ser dada a estas cuestiones radica en el mismo sentido de la manipulación y el cerco de la "decencia" creado sobre la identidad de género

\footnotetext{
${ }^{238}$ López Páez, p. 35.
} 
de cada uno de los integrantes de su núcleo familiar. Doña Herlinda es muy precavida al momento de crear los dos ámbitos de la vida de su hijo: el público y el privado. En el caso del primero, la imagen dada por Rodolfo ante la sociedad debe corresponder a la de un "hombre"; en el segundo sitio, la madre sabe que su hijo no podría ser feliz llevando únicamente dicha identidad, sino que precisa de ciertas necesidades sexuales, por tanto, la relación con Ramón no puede ser evitada. Por estos motivos, lo que parecía paradoja queda explicado: doña Herlinda, revistiendo las características clásicas de una "madre" y un "padre" mexicanos, se obliga a inducir a su hijo por el camino de la rectitud genérica y, en otro sentido, accede a las pulsiones eróticas de Rodolfo ante la imposibilidad de imaginarlo infeliz. Si Monsiváis mencionaba que la familia mexicana necesita crear un cerco capaz de expulsar y mantener al margen todo lo dañino, doña Herlinda lleva a cabo este cometido sin prescindir que lo "dañino" es lo imperioso para Rodolfo.

En este nivel, pareciera que el cuento brinda una auténtica salida al tema de la “disidencia sexual” en el ámbito familiar proponiendo un final afortunado; sin embargo, la situación es más compleja de lo que genera en una primera impresión. Sí, no hay duda de que doña Herlinda "acepta" - o claudica- ante los deseos de su hijo; sin embargo, esta posible asimilación es más bien un rechazo de los mismos, ¿por qué, si la madre conocía a cabalidad la sexualidad de su hijo, decide "armar" una boda con Olga? Obviamente, doña Herlinda concede cierta "razón" a los deseos de Rodolfo, pero, en una situación de mayor profundidad, no los acepta, y prefiere establecer una "rutina heterosexual", que al final resulta gozosa para todos los personajes. En este caso, la madre crea un artilugio teatral con la finalidad de brindar, ante los otros, la imagen que ella imagina correcta para Rodolfo. Doña Herlinda no puede pues concebir del todo la "homosexualidad" de su hijo; por lo contrario, la observa como algo peyorativo y digno de ser ocultado, pero, en un rol de madre más flexible y atenta 
a los requerimientos de sus hijos, no puede hacer la vida infeliz -por completo-a su retoño. Rodolfo entonces debe preservar y continuar la norma, aunque esto signifique una forma poco convencional y distanciada de establecer un lazo afectivo con Ramón, y, del mismo modo, tenga que crear un vínculo matrimonial con Olga, el cual conlleva, por supuesto, la reproducción. La heteronormatividad aparece erigida en la historia del cuento subrepticiamente, pero es claramente demoledora y constructora de los modelos que deberán seguir quienes están bajo su dominio. Así, aunque parezca paradójico, la familia formada por Rodolfo y doña Herlinda cumple con los requerimientos sociales para evitar una sanción por parte de su entorno; igualmente, la madre lleva a buen término el papel de forjar una conducta "adecuada" para su hijo. Incluso, lleva a tal grado su capacidad de empoderamiento y dominio sobre los otros que, cuando los padres de Ramón lo visitan, doña Herlinda los deja más que satisfechos al brindarles una imagen intachable e inmejorable sobre la casa en la cual habita ahora:

Las cosas comenzaron a complicarse cuando vinieron mis padres del norte. Yo tenía un cierto resquemo. El sólo imaginarme las preguntas que me haría mi madre me provocaba sonrojos. Los fui a encontrar al aeropuerto, en compañía de doña Herlinda y Rodolfo. Doña Herlinda conoce a una señora que regentea un hotelito, limpio y barato, y allí los instalamos. Los invitó a cenar, y ya estando en la casa, en el curso de la conversación les informó, pues yo no tuve tiempo de hacerlo, de que vivía allí con ellos. Después de la cena, camino al hotel, yo fue a llevarlos en el automóvil de Rodolfo, oí con incredulidad el comentario de mi madre: "Sabiendo que vives con esa gente se me han quitado tantas preocupaciones. Esta sí voy a dormir tranquila." Como mi madre es la de las opiniones y decisiones mi padre asintió con la cabeza. Días más tarde se fueron mis padres al norte, tranquilos y confiados de que por fin yo viviera en un hogar y no en una casa de asistencia, que de tan injusta mala fama gozan. 
La preservación de una conducta "intachable" hacia el exterior, hace de la familia de doña Herlinda casi un modelo "adecuado" con respecto a las expectativas sociales tenidas. El poder así queda instaurado desde un sitio inapelable y, a la vez, capaz de ajustar las vidas de cada uno de los personajes.

En esta dialéctica del ser y el parecer impulsado desde la figura de doña Herlinda, otro personaje importante en el cuento es Olga. Poco dice Ramón al respecto de ella, sólo que se trata de una noble joven, pero con la obsesión constante de obtener un matrimonio y forjar una familia. La irrupción de este personaje en la vida del narrador resulta, al principio, casi detestable. En la primera escena del cuento, en la cual doña Herlinda, Rodolfo y Ramón se encuentran comiendo frente al lago de Chapala, Olga adquiere una súbita importancia para el segundo personaje. Durante toda su estancia en dicho sitio, ambos pasan el tiempo de forma cercana, al grado de provocar terribles celos al narrador. Incluso, como el mismo Ramón lo menciona, este hecho genera en él un pequeño deseo de venganza y decide bailar con la primera chica que advierte sola. Ambos sucesos crean una breve escaramuza entre los personajes - de lo cual Olga no se entera o, en dado caso, prefiere no percatarse-: Rodolfo reclama a Ramón su proximidad con la otra chica, mientras este último alude que dicha acción tuvo como causa el frenético baile del primero con Olga.

Durante un tiempo, las salidas los domingos al lago de Chapala para la convivencia de los cuatro personajes se mantienen; no obstante, Rodolfo solicita a Ramón que, mientras el baila con Olga, él permanezca solamente a lado de su madre, doña Herlinda. Este panorama resulta muy interesante en la medida en que Rodolfo, a pesar de su "homosexualidad" y la relación con Ramón, mantiene una identidad masculina, obviamente impulsada por los designios de la madre, en la que la idea del dominio sobre los demás se hace también presente. La identidad de este personaje resulta un tanto emblemática, puesto que representa 
claramente el modelo correspondiente al "macho" en el sistema de deseo latinoamericano. Recuérdese aquí que, en dicho dispositivo, siempre la presencia del varón -en cualquiera que se sea su sexualidad, siempre y cuando no tenga un papel "pasivo" en el encuentro eróticoposibilita un ejercicio de poder con la capacidad suficiente para someter a "otros" individuos a su propio deseo. Dieter Ingenschay menciona sobre este tópico lo siguiente: "Los gay studies no se cansan de confirmar que el 'sistema' del deseo en vigor en América Latina acusa una diferencia central frente al 'sistema' norteamericano/europeo: mientras este último confirma una oposición binaria entre homo y heterosexualidad, la cultura latinoamericana dispone de otros ejes, en particular el eje activo vs. pasivo". ${ }^{239}$ Esta situación con respecto a la relación entre el género y la sexualidad en la cosmovisión latinoamericana es muy cercana entonces a Rodolfo. Así desde la postura de este personaje, es fácil advertir que su capacidad de ser "hombre" no se ve opacada con su relación con Rodolfo y que, además, puede mantener a buen resguardo su relación también con Olga. Ingenschay continúa diciendo más adelante: "La sustitución de la dicotomía masculino vs. femenino por la oposición activo vs. pasivo, corre el riesgo de representar una mera recodificación afirmativa de taxonomías binarias. [...]Se olvida (o se calla) otra problemática central: la de reproducir el modelo de una sexualidad definida por penetración, forma superada teóricamente por el tardío Foucault que desarrolla la idea de un goce desexualizado". ${ }^{240}$ La correspondencia entonces con el acto sexual de un ente "activo" induce a imaginar al "hombre" como "más macho" en la medida en la cual es capaz de mantener su dominio sobre un sujeto "femenino" y otro "masculino". A este respecto, Ramón no proporciona demasiados datos sobre sus encuentros sexuales con

\footnotetext{
${ }^{239}$ Dieter Ingenschay, "La literatura/cultura gay y lesbiana actual en Latinoamérica: postmodernidad y postcolonialidad", en Desde aceras opuestas, p. 9.

240 Loc. cit.
} 
Rodolfo, por tanto, no es posible corroborar cuál es su "rol". El narrador sólo los sintetiza como "trémolos sonoros" o "violín concertino", aludiendo con esto a sus estudios en el conservatorio y, también, a los sonidos emitidos por ambos personajes al momento de su acercamiento erótico, que por lo descrito serían sin duda explosivos y placenteros. No obstante, en cuanto a representaciones de género se refiere, Rodolfo congregaría en sí mismo esta apuesta por el sistema de deseo latinoamericano y, hasta cierto punto, prevalecería su "hombría" por el mismo hecho de matrimonio con Olga. Claro está que este sistema de deseo, convoca siempre a una situación más pública, con la cual el individuo haría alarde de su lugar como "activo" en ambas relaciones y tomando en cuenta la afirmación del poder con base en la penetración. En el caso del cuento, doña Herlinda prefiere, por razones evidentes, mantener en el ámbito de lo privado la relación de su hijo con el narrador; pero, desde una perspectiva simbólica, este acontecimiento de la dualidad del la sexualidad de Rodolfo resulta entonces muy alegórica en cuanto al sistema de deseo ya explicado. En este mismo sentido, Olga permanece en un "papel tradicional" de "madre-esposa", con el cual confirma su situación de subordinación en cuanto a la presencia de su esposo. Además, este hecho se ve agrandado con la presencia de la mentira: Rodolfo no sólo ejerce sobre ella un "dominio clásico" como ya bien lo dijo Monsiváis en cuanto a la idea de la "familia mexicana", sino que la coloca como un ser traicionado y, por ende, engañado por la conducta y magníficos ardides de su marido y de su suegra.

Ahora bien, y después de este repaso por las figuras de doña Herlinda, Rodolfo y Olga, queda solamente abordar el tema de la vida del narrador. Los anhelos de Ramón son, desde el inicio del cuento, bien claros: desea estar con Rodolfo y mantener una relación afectiva con él. Por tanto, la presencia de Olga viene a arrebatarle este proyecto y, claro está, se siente en un plano de inferioridad y supeditación. El ámbito de lo marginal aparece bien 
marcado en este cuento cuando el narrador se observa desde una perspectiva de inferioridad o "poca importancia" con respecto al énfasis dado a la "relaciones públicas" de Rodolfo. En este aspecto, es pertinente acotar también cómo el personaje crea para su deseo un espacio alterno al oficial, es decir que, a pesar de las escaramuzas realizadas por doña Herlinda y por Rodolfo para mantener a buen resguardo su relación, hay un cierto dejo de melancolía en cuanto a la percepción sobre su sexualidad. De este modo, a pesar de que Ramón dictamina al final del cuento su necesidad de los nuevos individuos con quienes habita -"vivo con una familia extraordinaria, de la que no puedo prescindir"-, a lo largo de su discurso existe una nostalgia por la imposición de un paradigma sexual.

El deseo homoerótico de Ramón está circunscrito a una matriz de identidades que, por razones claras, lo mantienen en un ámbito periférico. En consecuencia, "Doña Herlinda y su hijo" tiene un toque más de nostalgia y tristeza, por la forma de vivir la homosexualidad por parte de los personajes, que de reivindicación. Indudablemente, los personajes del relato funcionan en un modo alegórico - tal como lo han hecho buena parte de los textos revisados hasta ahora en este trabajo- y asumen, por tanto, un "rol" que bien puede representar a los diferentes actores de la sociedad mexicana.

Como ha ocurrido a lo largo de la literatura del país en cuanto a la definición de una identidad, el cuento opera en el mismo sentido de plasmar simbólicamente cada uno de los bastiones en los cuales está articulada la idiosincrasia y cosmovisión de México. El papel de la madre, el hijo, el amante "homosexual" y la esposa establecen una serie de equivalencias con el aforo suficiente para convocar y reflexionar sobre el habitus existente en la geografía nacional. Resulta imposible dejar a un lado entonces la adjudicación de una identidad “oprimida" por parte de Ramón como un hecho en el cual los mecanismos de la dominación cobran vida. Obviamente, la relación con Rodolfo está dada por el lazo afectivo y sexual 
tendido entre ambos; sin embargo, esta unión tiene un carácter "prohibido" que el personaje, a través del empoderamiento y toma de decisiones por la madre, estereotipa y, de algún modo, amplía a través de su mismo sometimiento. Para este fin, la distribución espacial de la casa de doña Herlinda es, por antonomasia, una representación clara de la ubicación, en cuanto a valores morales se refiere, de la heterosexualidad y la homosexualidad. Así, cuando Ramón arriba a dicho espacio, su lugar está en la habitación de Rodolfo. Posteriormente, con la llegada de Olga, el narrador es desplazado a un departamento construido exclusivamente para él: "He dicho antes que la casa es grande. Antes de que Olga terminara su primer embarazo, doña Herlinda hizo un departamentito encima del garaje. Tiene dos puertas, una por supuesto a la calle y otra hacia la casa. En cualquier situación siempre hay una salida, y debo de registrarlo, Olga no es entrometida y hasta la fecha esta situación no se ha presentado". ${ }^{241} \mathrm{La}$ distribución espacial tiene una repercusión clara en el plano de lo simbólico: la "salida" de Ramón hacia un sitio periférico es la misma que el "homosexual" posee en el ámbito de la sociedad latinoamericana. Si bien los discursos liberadores han promovido una "aceptación", que ha sido duramente criticada por los teóricos queer, esto no ha ocurrido en los términos de una inclusión firme; por lo contrario, en múltiples ocasiones este hecho opera siempre en una papel marginal. Una forma más clara de advertir esta cuestión radica en los guetos formados en diferentes ciudades por la comunidad gay, quien ha creado espacios claramente delimitados en los cuales se puede hacer una vida "normal" en cuanto al homoerotismo se refiere; fuera de esta demarcación geográfica, el sujeto "homosexual” es, sin duda, objeto de escarnio y exclusión.

\footnotetext{
${ }^{241}$ López Páez, p. 38
} 
El departamento de Ramón dentro de la casa de doña Herlinda vendría a representar entonces este concepto de gueto, en el cual la sociedad "delimita" las identidades impertinentes al respecto de la cosmovisión sexual normativa; sin embargo, existe otro guiño dentro del cuento: doña Herlinda y su hijo visitan con frecuencia el apartamento del narrador: "Ha habido ocasiones, muy especiales, como un aniversario o alguna situación aflictiva para mí, en que Rodolfo se ha quedado hasta la madrugada. También el departamento le ha servido de refugio a doña Herlinda: les deja su casa al matrimonio y se viene conmigo a tomar sus tequilas, o simplemente a platicar". ${ }^{242}$ Esta circunstancia favorece mucho la relación entre los amantes y, a la vez, fortalece el lazo afectivo tendido entre el narrador y la doña Herlinda. Cabe recordar aquí que la madre hace ciertos "arreglos" para que Rodolfo pueda visitar, los martes y los jueves por la noche, a Ramón sin tener la presencia de Olga por la casa. Así, en el plano simbólico, la entrada de Rodolfo y doña Herlinda al departamento implica una complicidad con lo "otro", es decir con lo ajeno o poco reconocido. Los personajes configuran un espacio en el cual habitan pues con una visión entre lo aceptado y lo punible; no obstante, es evidente que todos transitan por ambos sitios, tal como una sociedad establece sus reglas con respecto a lo normado y lo excluido. El poder queda conformado con base en los diferentes vericuetos de territorio, a los cuales, en actitud pasiva y acomodaticia, el narrador observa favorablemente. Antonio Marquet comenta lo siguiente sobre este escenario: “Tanto en 'Opus 123' como en 'Doña Herlinda y su hijo, se produce el sometimiento de los protagonistas a un orden de valores ajenos a sus intereses vitales. Feliciano Larrea queda en el extremo de autocastración; Moncho; sin embargo, permanece en una especie de servidumbre, supeditado al apetito sexual de Rodolfo que logra reunir a la

\footnotetext{
${ }^{242}$ López Páez, p. 39.
} 
esposa y al amante bajo el mismo techo, además de servir como compañía a Herlinda" ${ }^{243} \mathrm{Y}$ aquí lo dicho por Marquet adquiere un tono fundamental al comentar el cuento de López Páez, ya que, como bien se dijo al principio de este análisis, la historia no favorece una suerte de reivindicación con respecto a la "disidencia sexual"; por lo contrario, la coloca en un ámbito subalterno y marginal: es aceptada siempre y cuando permanezca en un sitio periférico. En este sentido, la vida de Ramón permanece como un satélite que gira en torno a Rodolfo y doña Herlinda, ambos obtienen del narrador lo que les place y éste subsiste solamente en una actitud servil, consumiendo, de vez en vez, las migajas de amor brindadas por su amante.

Por otro lado, esta supeditación de Ramón a los designios de doña Herlinda no es más que un aferramiento a la norma por parte del personaje, quien no puede observarse fuera de una dialéctica en la cual el poder lo mantiene en un distrito poco adecuado. El cuento de López Páez ilustra bien estas estrategias del sometimiento al crear un universo narrativo profundamente cercano y conmovedor con respecto a la sociedad mexicana- donde el poder se expresa en términos sólidos. Probablemente, el narrador sea el más "ofendido" con los estratagemas de doña Herlinda para hacer feliz a su hijo y dar, ante el exterior, la imagen de una familia "correcta"; más Ramón no es el único, a su modo, doña Herlinda y Rodolfo padecen estos designios con la creación, en su propio panorama cultural y de vida, de una estructura articulada conforme a preceptos claramente determinados por el patriarcado y la heteronormatividad. Al principio del relato, cuando Ramón responde a Rodolfo que él bailó con la chica de enfrente por ciertos celos sufridos al observar a este último en regocijo con Olga, Rodolfo sólo atina a esgrimir que son cosas realizadas para satisfacer a su madre. Si

\footnotetext{
${ }^{243}$ Antonio Marquet, iQue se quede el infinito sin estrellas!, p. 557.
} 
bien parece que Rodolfo podría deleitarse de la presencia de la esposa y del amante en el mismo sitio, en realidad "sufre" una cruel embestida por el poder materno, y este poder, a su vez, está siendo manipulado por una conciencia profundamente extrínseca, en la cual el hermetismo contra la "disidencia sexual" y la necesidad imperecedera de fomentar en los demás -sobre todo quienes están bajo el dominio propio- una "pasión” por lo normativo. A final de cuentas, todos los personajes son sujetos implicados en complejas redes del poder que mantienen sus deseos e identidad acuartelados: doña Herlinda, Rodolfo, Ramón y Olga Obed, obedecen a una ley fuera de ellos mismos $-\mathrm{y}$, a la vez, interiorizada gravemente-, que los preserva en una constante opresión:

El poder es simultáneamente externo al sujeto y la propia jurisdicción del sujeto. Esta aparente contradicción cobra sentido cuando entendemos que sin la intervención del poder no es posible que emerja el sujeto, pero que su emergencia conlleva el disimulo de aquél Se trata de una inversión metaléptica por la cual el sujeto producido por el poder es proclamado como sujeto que funda al poder. El carácter fundacional del sujeto es efecto de una operación del poder, que se realiza mediante la inversión y ocultación de esa operación previa. Ello no quiere decir que el sujeto pueda ser reducido al poder por el que surge, ni tampoco que el poder por el que surge sea reducible al sujeto. El poder nunca es sólo una condición externa o anterior al sujeto, ni tampoco puede identificarse exclusivamente con éste. Para que puedan persistir, las condiciones del poder han de ser reiteradas: el sujeto es precisamente el lugar de esta reiteración, que nunca es una repetición meramente mecánica. Conforme la apariencia del poder pasa de condición del sujeto a efecto del mismo, las condiciones del poder (anterior y externo, asumen una forma presente y futuraria). ${ }^{244}$

\footnotetext{
${ }^{244}$ Judith Butler, p.78.
} 
Con base en estos axiomas, la definición de los personajes del cuento como seres estructurados bajo una determinada representación social resulta muy bien determinada. Podría decirse que una de las posibilidades de interpretación presentadas por el texto está enclavada en este ámbito, sobre todo cuando "Doña Herlinda y su hijo" propone cómo las dos caras de del poder -hegemonía y subversión- son proclamadas desde la misma corporalidad y actos de identidad de cada uno de los personajes. De algún modo, cada uno de estos sujetos encarna una máscara y una serie de actividades no necesariamente a partir de su propio deseo, sino a partir de lo estipulado desde una convención; por tanto, aunque la madre está obsesionada por brindar una imagen "normal" de su hijo -y éste, por su parte, se obstina también en complacerla-, en realidad lo que ocurre es un complejo proceso de redes simbólicas de poder, dado que -como ya se anotó páginas atrás al hablar de la noción de familia en el texto- ella no es un ente con una libre capacidad de decisión: doña Herlinda obedece también a una abigarrada e inflexible concepción del cuerpo. Paradójicamente entonces, pero profundamente demoledor y auténtico, el patriarcado y la heternormatividad son expresados a través de la figura femenina, quien, en ambas instancias, resulta terriblemente perjudicada por su papel subordinado. Así, en el cuento de López Páez ocurre algo similar a lo anotado por Gloria Anzaldúa en su texto "La prieta". En dicho artículo, la autora chicana proporciona una visión muy amplia de lo que significa para ella ser morena, descendiente de mexicanos y mujer en Texas; además, propone cómo la propia "víctima" se convierte, sin desearlo claro está, en la constructora de los vericuetos de afirmación colonial en sus seres más cercanos, sobre todo en quienes tiene la posibilidad de formarlos. Este mismo incidente sucede en "Doña Herlinda y su hijo": la madre es un ser sujeto a reglas, y enseña esas redes entre su descendencia. La víctima pues termina convertida en un verdugo por la misma posibilidad de construcción establecida en ambos casos. 
Ahora bien, Rodolfo y Ramón caen irremediablemente en este juego sin proponérselo ni buscarlo. Ambos personajes sufren el sometimiento y, a pesar de practicar su sexualidad y sentirse satisfechos con ella, repliegan el deseo homoerótico al cercado de lo oculto y prohibido. En este punto es en donde el "homosexual" profiere un discurso idéntico al de la heteronormatividad y, para obtener pequeñas ventajas de aceptación y goce, continúa con la reproducción exacta de los roles ya especificados. Sí, no hay duda de que los dos personajes "luchan" por su mantener a flote su relación y, de alguna manera, logran restarle una parte, en cuanto a capacidad de dominio se refiere, a la heterosexualidad; sin embargo, están inmersos en un juego cruel en el cual ocupan las mismas normas de (auto) supeditación manifestadas desde el cenáculo del poder. Además, la actitud de conformismo advertida subrepticiamente en Ramón y Rodolfo amplía esta afirmación: ambos personajes "aceptan" calladamente las decisiones promulgadas "desde afuera" y exigen, a sus más intrínsecos deseos, la eliminación de cualquier idea de subversión al respecto. Esto estaría en concordancia directa con lo anotado por Monsiváis al respecto de la lógica del ocultamiento: mientras la "disidencia sexual" permanezca como situación soterrada y marginal, incluso hasta por los mismos "practicantes" de ésta, poco podrá hacerse en cuanto a un cambio de paradigma de género y sexualidad se refiere. En consecuencia, el cuento de López Páez expone, sin duda, las ganancias obtenidas por el largo y difícil proceso de liberación sexual producido en México, pero también pone el dedo sobre la llaga al manifestar las diatribas de dicho movimiento y el "sacrificio" de la visibilidad a cambio de unas horas -los martes y los jueves de siete a nueve de la noche- de placer.

A diferencia de "Doña Herlinda y su hijo", el próximo cuento que se analizará aquí, "Perder a Orfeo" de Luis González de Alba, posee una perspectiva sobre la "disidencia sexual" que no necesariamente raya en el ocultamiento o la desidia con respecto a la 
manifestación del deseo. Puede decirse de forma general que la mayoría de los cuentos conformadores del volumen El vino de los bravos (1981), y cuya historia aborda el tema del homoerotismo, afirman siempre una sexualidad desde el plano de la exhibición o la negativa a mostrarse en un ámbito marginal. Además, sin duda, se trata de la colección de cuentos con las descripciones más abiertas y claras sobre escenas de contenido "homosexual". "Hoy te he recordado...", "El hombre de Nebraska", "Perder a Orfeo", "El vino de los bravos" y "Posdata que llevaría el Vampiro de la Colonia Roma" son textos en los cuales emerge, sin mayor preocupación o pudor, una amplia revelación del cuerpo en relación con el deseo homoerótico. Incluso, el cuento homónimo del título del volumen no escatima en las referencias al ámbito de la sexualidad siempre desde una postura transgresora. El narrador alude tajantemente al cuerpo como centro de placer, desprovisto de cualquier atadura de género o, en dado caso, juega con estas reglas para crear un universo plenamente sexual.

En el caso de "Perder a Orfeo", la alusión al homoerotismo es directa y el tratamiento dado al mismo no estriba en un cuestionamiento del régimen de una sexualidad hegemónica, sino en el ajustamiento de esta normatividad al ámbito "homosexual". La historia, plantea, desde el inicio la relación entre el narrador y el cuerpo de los otros. Y es en esta medida en la que propone siempre una visión concreta del deseo y sus diversas posibilidades. Así, el relato, en buena parte, se convierte en una constante loa de la piel, el olor, el sabor, la forma y la pasión por el cuerpo "viril". El cuerpo "masculino" es, a lo largo del texto, el centro de la atención y el sitio sobre el cual reposa el sentido de la "vida" del narrador: la búsqueda y encuentro de aquel varón con las características más acérrimas de "virilidad" y belleza es el objetivo del protagonista, y esto último puede darse incluso a costa de poner en peligro la propia existencia, dado que la búsqueda puede llevar al sujeto a entornos cargados de violencia. 
Cabe destacar aquí que los cuentos de El vino de los bravos -a excepción de "Hoy te he recordado..." y "Posdata que llevaría el Vampiro de la Colonia Roma"- poseen diégesis ubicadas en ciudades alejadas de la geografía nacional y, con frecuencia, aparece ésta con el fin de establecer paralelismos o, en su caso, visiones alternas sobre la "disidencia sexual". Por ejemplo, en "El vino de los bravos", el protagonista es un chico mexicano que hace un recorrido turístico y sexual por varias ciudades europeas; no obstante, a través de este periplo realiza siempre una mención de sitios ubicados en México y los alude con la visión de un fluir de la conciencia, lo cual deja al lector con la impresión de estar frente a un comparación entre sensaciones corporales anteriores y presentes. "Perder a Orfeo" no hace a un lado esta constante y tiene una historia ubicada en Río de Janeiro, circunstancia que le permite crear un discurso lúdico a partir de la cosmovisión de la cultura brasileña, la mexicana y, como puente entre las dos, la mitología griega. El protagonista, mexicano también como en el caso de "El vino de los bravos", es un joven que ha viajado por motivos turísticos -la presencia del carnaval- a Río e indaga en las prerrogativas ofrecidas por dicha ciudad en cuanto a carnalidad se refiere. A la mitad del discurso, dado que el relato se encuentra in extemis, el narrador-personaje aclara lo siguiente sobre su estancia en Brasil:

\footnotetext{
"Por aquí no vengan nunca, sobre todo de noche", nos había dicho el chofer del taxi a un amigo mexicano y a mí, yendo del aeropuerto a la ciudad. Y desde esa ocasión se me habían ido los ojos sobre las aceras repletas de una multitud abigarrada y distante. Nos hospedamos en un hotel de un buen barrio, como correspondía. Por las mañanas íbamos a la playa de moda, subíamos a los miradores. Un par de turistas que esperan el carnaval y desean conocer lo mejor de la ciudad. Y sin embargo, para mí lo mejor había
} 
quedado atrás, en la visión instantánea de Praça Mauá, los barcos, las luces parpadeantes que anunciaban los bares, la multitud colorida y aún sin rostro. ${ }^{245}$

Este hecho no es para nada una cuestión gratuita en el desarrollo del cuento, ya que, aparte de modificar tajantemente la diégesis, afecta la concepción tenida sobre la "homosexualidad" o, mejor dicho, articula un discurso contestatario contra una posible homonormatividad. Claro está que hay dos posibilidades contrarias en el cuento: continuar como "turista" dentro de la ciudad y desarrollar la estancia en un ámbito cómodo o, la preferida por el narrador, acercarse a sitios no tan aptos para la presencia de los extranjeros. Esta segunda opción es, a la vez, una crítica al surgimiento de una comunidad gay hermética y aferrada a ciertas representaciones. Por este motivo, el que el protagonista se sienta atraído por lo sórdido es una circunstancia cercana a la presencia del deseo. Y esto queda claramente manifestado en el párrafo siguiente a la cita anterior: "Un día antes dije adiós a mi amigo, a nuestras cuentas escrupulosamente compartidas en los restoranes, y me instalé en uno de los lugares más sórdidos del mundo, un hotel para cavalheiros, un hotel sólo para hombres porque los servicios son comunes: excusados y regaderas de agua fría al fondo". ${ }^{246}$ La preponderancia de lo soterrado aparece entonces como un letimotiv a lo largo de cuento y propone una perspectiva poco convencional sobre el hecho homoerótico. El rechazo del narrador a vivir como "turista" en un ambiente de clase media o alta resulta el trampolín narrativo del texto, con base en esto el personaje puede deambular por los barrios más marginados de la ciudad, pero observar en ellos la latencia del deseo y la auténtica felicidad en cuanto al encuentro de una relación afectiva se refiere.

\footnotetext{
${ }^{245}$ Luis González de Alba, El vino de los bravos (México: Katún, 1981), p. 52.

${ }^{246}$ Loc. cit.
} 
Este giro en la historia del cuento hace notoria la resistencia a un posible estándar internacional de la "vivencia gay". El espacio "delimitado" para el flirteo homoerótico es una suerte de celada para el personaje y prefiere desecharlo por parecerle inconveniente a sus objetivos. De este modo, al principio del cuento, el narrador describe la existencia de un bar gay y la convivencia de la clientela efectuada en él:

Entró a aquel bar del Passagem Florida donde la pegajosa femineidad de la concurrencia masculina me contagiaba con su juego de colegialas. [...] ¡Carajo! ¡Qué tedio más grande puede ser la jotería! Todos aquellos muchachos empecinados en desempeñar lo mejor posible el papel de su hermana Margarita cuando habla por teléfono con Pepe, el más guapo de los amigos que juegan futbol las mañanas de domingo. "No vuelvo. Me iré a los muelles en un rato más". 247

Es transparente la advertencia de una oposición entre el mundo de una posible concepción homoerótica norteamericana y otra latinoamericana-mediterránea. Como se ha mencionado ya a lo largo de este trabajo, en el primer caso siempre hay una visión de una identidad gay en los dos actores que intervienen en la relación sexual; en el segundo caso, la cercanía con la disidencia sólo afecta a quien desempeña el papel de "pasivo". A su vez, esta contrariedad produce casi siempre la idea de una equiparación y emulación del mundo "homosexual" con respecto al "heterosexual". El cuento revela, por tanto, el hartazgo de la primera perspectiva y la proximidad con la segunda, pero, más que esto, el regocijamiento con la imagen de la "virilidad" y el rechazo a cualquier tipo de "afeminamiento". Así, es posible colocar frente a frente dos imágenes de un mismo deseo: los chicos del bar gay y los asistentes a la Praça Mauá. Sin embargo, observar como un binomio este suceso si bien resulta accesible no aclara

\footnotetext{
${ }^{247}$ Idem, pp. 49-50.
} 
del todo la apuesta del protagonista. Hay, ante todo, un proceso de desmantelar los guetos impuestos y, a la vez, destruir cualquier convención sobre la sexualidad, pero, paradójicamente, la presencia de lo masculino como estado de deseo permite también una configuración hermética. El problema es más amplio entonces de lo que podría pensarse: el narrador observa con cierto desgano las posturas "femeninas" de los chicos asistentes al bar, pero "ama" notablemente la "masculinidad" plasmada en los cuerpos de Praça Mauá. Ambas situaciones están imbricadas en una "matriz" de identidades; por tanto, a pesar de reconocer una "libertad" en cuanto al deseo se refiere, la concepción del cuerpo con base en un rígido sistema de representaciones genéricas todavía continúa. La cuestión estiba en una coalescencia entre un posible deseo intrínseco y otro manipulado por el simbolismo de la heterosexualidad. Ambas posturas crean una mezcla homogénea y enmarañada en el narrador, puesto que podría parecer que hay una presencia de la automarginación en cuanto a la concepción de la "disidencia sexual" se refiere; no obstante, ésta es nula en cuanto a la reflexión sobre el cuerpo y los placeres obtenidos del mismo. El protagonista para nada expresa un sentimiento de inferioridad con respecto a un posible advertimiento de la dualidad homo/hetero; por el contario, la exhibición placentera de cualquier realidad relacionada con el placer, por más escabrosa que parezca, es anotada con detalle. Hasta aquí cualquier atadura o posición de poder queda totalmente abatida por la perseverancia del narrador en su propio deseo; pero, por otro lado, este mismo deseo está revestido por una gruesa capa de cuestiones relacionadas con un sistema de género bien definido. La misma concepción de la masculinidad es un hecho que no puede desapartarse de esta circunstancia.

Ahora bien, cuando el narrador rememora la presencia de los dos personajes a quienes admira por su belleza y masculinidad, hay siempre un llamado a la concepción de lo homosocial con base en un plano erótico. Roberto y Newton son dos jóvenes, "mulatos, altos 
y guapos", a quienes el protagonista conoce y con quienes establece cierta proximidad. En este punto, el narrador relaciona su vivencia con los dos sujetos con base en una relación fraterna, pero anclada a cierta complicidad de lo masculino. En otras palabras, lo que da solidez y mantiene la convivencia entre los tres personajes, así como el enorme deseo por parte del narrador, es la relación en un ámbito de "masculinidad" existente entre ellos. El lazo tendido por el género permite entonces este plano de lo homosocial, en el cual cada uno de los individuos puede encontrarse con "cierta libertad" y, también, con la posibilidad de proclamar en el otro un flirteo con base en el cobijo del contacto entre pares. Esto se observa con claridad cuando el narrador relata las actividades de Roberto:

\footnotetext{
Roberto se andaba padroteando a una puta más bien desabrida que fichaba a unas calles de la Praça, y yo lo había acompañado con frecuencia a arreglar sus negocios. Yo era "o seu amigo mexicano", lo cual sonaba u seu amigu meshicanu, y me sentía envanecido y satisfecho cuando Roberto le dedicaba un rato a su amiga, pero un rato apenas, como si en efecto fuera sólo por necesidad, por negocio, y volvía conmigo para abrazarme, seguir toda la noche de parranda, tomando cervezas, orinando en la calle y, por supuesto, reanudando aquella comunicación secreta y codificada en la que aún no quedaban claros todos los términos, pero en la que ambos teníamos en mente lo mismo. Misterios Eleusionos reservados, como siempre, a los hombres. ${ }^{248}$
}

La referencia a lo "femenino" está dada casi por una circunstancia de menosprecio, mediante la cual, el protagonista puede afirmarse como "amigo" de Roberto. El trato homosexual establecido entre estos dos personajes crea un paradigma masculino que bien puede servir para encarar una circunstancia homoerótica. Cuando el narrador observa cómo el joven mulato olvida a la chica para estar compartir mayor tiempo con el primero, ocurre una

\footnotetext{
${ }^{248}$ Luis González de Alba, El vino de los bravos, p. 51.
} 
enajenación de la relación entre "pares". Por estas razones, es fácil advertir la presencia de un anhelo constante de gozar de la "virilidad" de Roberto o Newton frente al rechazo de cualquier afeminamiento.

Por otro lado, hay una alusión evidente al color de la piel como manifestación del deseo. En esta comparación entre los dos ámbitos, la Praça y el bar gay, el narrador persiste en señalar el tono de la piel como una correspondencia con el reiterado binomio "masculino/femenino": el primer rubro anclado a un hombre de tez oscura y, el segundo, a un semblante mucho más claro. Esta obstinación coincide con una visión tradicional acerca del deseo homoerótico, y para constatarlo bastarían dos ejemplos literarios al respecto: $E l$ buen negro (1895) de Adolfo Caminha y Hombres sin mujer (1938) de Carlos Montenegro. En la primera novela, hay dos personajes identificados con una taxonomía muy circunscrita de la homosexualidad: Bom-Crioulo -a quien corresponde una representación "masculina"y Aleixo -anclado irremediablemente al ámbito de lo "femenino"; ambos personajes crean una dualidad muy próxima a la concepción de la "heterosexualidad". Por otro lado, en la novela de Montenegro ocurre algo similar con respecto a los personajes encarcelados Pascasio y Andrés, el primero rebosante de "virilidad" y el otro más cercano a la "debilidad". La apariencia entonces del cuerpo queda ceñida brutalmente a una condición inapelable de lo simbólico. De este modo, la construcción del género, la sexualidad y el deseo parecen obtener mayor provecho de una circunstancia racial. Mientras que la tez oscura rotula directamente la posibilidad de encarnar un revestimiento "masculino", la blancura acercaría el cuerpo a una circunstancia de afeminamiento. La adjetivación del narrador no resulta gratuita y, sobre todo, hace hincapié al final del texto en la idea de la pérdida de dicho modelo de "hombría": 
El Passagem Florida estaba iluminado, como siempre con aquella inmisericorde luz de neón. Por un extremo, como a través de un túnel, se veía el mar, el inicio de un amanecer rosáceo sobre la bahía; por el otro, la calle donde ya circulaba algún autobús mañanero, todavía con las luces encendidas. Al fin. Había empezado la cuenta de mis días felices, "los días que pasaré en tus brazos" me dije, y con una sonrisa quise repetírselo, pero a mi lado caminaba un muchacho gordito, blanco, de manos pequeñitas, de andar ligeramente afeminado y olor ácido como el sudor de las mujeres. Me detuve para esperar a mi amigo. Hacía atrás el Passagem estaba vacío. Con una sonrisa embarazada empecé a explicarle al desconocido, quien parecía esperar cortésmente a que yo concluyera mi frase, que no le hablaba a él. Pero al mirarlo de nuevo en encontré un remoto parecido con el hombre a quien estaba dirigida la solicitud de que me tuviera para siempre en sus brazos. ${ }^{249}$

Debe recordarse aquí que el narrador ha estado tomando un par de copas en el citado bar y, posiblemente por este hecho y la presencia de la noche, ha observado a un chico con las facciones deseadas por él; no obstante, como el fragmento citado señala, dicho avistamiento es sólo una suerte de alucinación provocada por el alcohol y la oscuridad y, en realidad, a quien ha deseado se "trasforma", a la luz del día, en un chico poco adecuado para el anhelo del narrador. La corporalidad del personaje "redescubierto" pone en evidencia la cercanía con la "femineidad" y crea un lamentable rechazo en el narrador.

A partir de esta idea de la ausencia del prototipo "masculino" deseado se crea pues la misma concepción del cuento y, claro está, del título: "Perder a Orfeo". La relación con el mito es evidente; sin embargo, se propone una inversión del mismo. Si en el mito griego es Orfeo quien, al salir de la cueva que lo conduce del inframundo a la tierra de los vivos, extravía a Eurídice, en el cuento sería el narrador quien podría perder aquello que desea. Por otro lado, la inversión también se manifiesta en el hecho de que Orfeo pasa de ser el sujeto

$$
{ }^{249} \text { Idem, p. } 59 .
$$


deseante a ser objeto deseado: el narrador ratifica la búsqueda, en el posible submundo representado por el bar gay, del objeto amado, pero la pérdida queda manifiesta en el mismo hecho con el cual, al llegar a la luz del día, el narrador se da cuenta de que la persona a su lado no corresponde con el "modelo" codiciado. Así, del mismo modo a como ocurre en el mito, en el tránsito de la oscuridad a la claridad el protagonista sucumbe y lamenta el hecho de encontrarse frente a un individuo con características diferentes.

Por otro lado, y cercano al suceso de la reminiscencia del mito de Orfeo en el cuento, el narrador refiere en sus últimas páginas la presencia constante de la muerte. Señala, en primer término, el acudir al Passagem Florida como un fallecimiento, similar a la asfixia producida en el personaje cuando era niño y casi se le da por muerto. De este modo, el mito todavía adquiere mayor preponderancia en la misma caracterización del bar gay como el lugar del inframundo. En este caso, el narrador tomaría el lugar de Eurídice, quien desea ser rescatada por Orfeo para mantener su idilio en la tierra. Igualmente, cuando esta Eurídice mexicana y moderna se enfrenta a la realidad -a la luz- no hay más remedio que retornar a la muerte, desde la misma concepción de que Orfeo ha quedado extraviado en alguna alucinación. Simbólicamente, el narrador pasa de un estado de anhelo constante de la "virilidad" a un desplome en el ámbito de lo "femenino", puesto que acepta la salida con el joven afeminado visto a la luz del amanecer: "Vi la grada y seguí de largo, dejándome conducir como un toro que llevan al matadero, sin escuchar lo que me decía, con un gran nudo en la garganta que supe disimular". 250

Como se ha visto, la construcción del deseo en "Perder a Orfeo" está marcada por una circunstancia de género que, en cierto modo, podría parecer castrante y con un gran poder

${ }^{250}$ Luis González de Alba, El vino de los bravos, p. 60. 
para limitar la sexualidad. No obstante, este cuento demuestra la proximidad con la norma al momento de efectuar un deseo. Con esto no pretende decirse aquí que la visión sobre la "libertad sexual" es imposible de concebir sin la correspondiente "matriz heterosexual"; pero no cabe duda de que ambas asimilan modelos de una y de otra para construir su propia perspectiva sobre el cuerpo. El texto de González de Alba no hace más que señalar esta coyuntura y designar cómo, si bien el deseo es una cuestión intrínseca y que radica en buena parte en un estrato psíquico del hombre, no está exento de una impregnación de la norma. Esta dialéctica no debe observarse como una situación indeleble o frustrante; por lo contrario, existe por la misma razón del género y resultaría casi imposible imaginar un estado de deseo sin ella. El problema estaría focalizado entonces en una red de poder, es decir que el deseo por más libertario que sea y colmado, a la vez, de reminiscencias del estatuto de género-, no implica, por sí mismo, un conflicto: la diatriba se encuentra en dotar de poder cualquier manifestación del deseo e imponerla como hegemónica o "única". El protagonista de "Perder a Orfeo" antes que cualquier otra cuestión tiene la capacidad de decidir sobre su propio cuerpo y las medidas sexuales necesarias para su "correcto desarrollo". El cambio entonces de una situación de comodidad por buscar en un barrio marginal aquel cuerpo que pudiera resultar anhelado y placentero se plantea como un apéndice a cualquier latencia demarcadora. A su vez, el rechazo a una posible comunidad gay con reglas bien guarecidas y representaciones hegemónicas plantea la posibilidad de elección y la ruptura con respecto a la creación de un universo hermético. En consecuencia, el texto de González de Alba afirma la pertinencia del deseo y los complejos vericuetos en los cuales se halla; claro está que estos vericuetos están relacionados directamente con el universo sexo/genérico creado y amparado ya bajo las instituciones sociales; no obstante, desde el mismo hecho en el cual el narrador 
se aventura en un recorrido por los recovecos de Praça Mauá produce la fractura y la destitución del dispositivo del poder.

De modo alegórico, podría interpretarse, pues, la presencia del taxista que decide ofrecer un consejo a los turistas, alejándolos de los barrios marginados, como una clara alusión a una norma que, en aras de conservar la comodidad o, incluso, la propia existencia, genera un espacio geográfico -y corporal- bien circunscrito. En este mismo rumbo estaría una hermosa descripción del cuento, en la cual el protagonista anda con el torso desnudo por las calles:

Yo me perdía entre aquella multitud semivestida; a la luz del sol o a la media noche, vagaba con la misma camisa, sucia, el pantalón vaquero desteñido y las sandalias rotas. A veces sin camisa y descalzo, con sólo el pantalón por toda prenda, sintiendo el cemento ardiente de la acera, las costuras ásperas del pantalón, pisando cáscaras de mango; con el sol en la espalda como un abrazo cálido y excesivo; jaloneado por las putas a la puerta de los burdeles diurnos; rodeado por una resaca humana que en las cantinas abiertas a la calle nada más salía de su sopor alcohólico durante los esporádicos asaltos de la policía militar que de vez en cuando se llevaba a rastras algún negro luego de macanearlo. Perfectamente mimetizado con el medio en tanto no abriera la boca y me denunciara el acento extraño. ${ }^{251}$

La idea de andar semidesnudo por la calle es un hecho que sacude por completo al protagonista y lo coloca en un plano de mayor empatía con los habitantes del entorno que visita. A su vez, el sentir el sol sobre su espalda simboliza esta posibilidad y el contubernio con un exuberante universo erótico. Al mismo tiempo está la presencia del pantalón que, sin pecar de sobreinterpretación, podría llevar a buen término una concepción al respecto de los límites creados por una sexualidad hegemónica. En consecuencia, el personaje estaría

\footnotetext{
${ }^{251}$ Idem, p. 50
} 
disfrutando de un desbordamiento de su libido, pero en este mismo acontecer encuentra ciertas "barreras" que, a final de cuentas, también pueden "encajonar" el deseo de modo subrepticio.

En el caso de "Perder a Orfeo", el dolor de la pérdida del objeto de deseo o la transfiguración del mismo en otro ser implica entonces un fuerte dolor que conmueve por completo al protagonista, al grado de relacionar este hecho con la muerte; sin embargo, en el siguiente cuento aquí estudiado, "De amor es mi negra pena" de Luis Zapata, el dolor producido por la pérdida - pero en este cuento sería una pérdida de una identidad prestigiadadegenera en la autodestrucción. El suicido, en este caso, es una de las múltiples salidas, como ya se acotó en paginas anteriores, dadas al asunto homoerótico en una sociedad heteronormada y profundamente machista.

El cuento de Zapata es un texto que ya ha sido estudiado con anterioridad; sin embargo, para dar continuidad a la labor crítica e historiográfica realizada en estas páginas, resulta pertinente rescatarlo -sobre todo desde la perspectiva del machismo y el temor al escarnio-, apoyándose, por supuesto, en otros textos que ya han realizado un análisis del relato.

Antes de continuar, se hace preciso mencionar que "De amor es mi negra pena" es un texto incluido en el excelente volumen de cuentos titulado Ese amor que hasta ayer nos quemaba (1983), aunque fue escrito por Zapata hacia 1976, como él mismo lo señala al final del texto en la edición señalada. Varios de los relatos incluidos en el libro abordan directamente el tema de la "homosexualidad" y la relación agridulce de los personajes con dicha etiqueta. "Ese amor que hasta ayer nos quemaba", "Las zapatillas rojas", "La cuenta de los días" y "De amor es mi negra pena" son textos en los cuales emerge el ámbito de la "disidencia sexual" de forma excepcional y, por tanto, reveladora. Esto no resulta novedoso 
en un escritor como Zapata, quien ha sido considerado por parte de la crítica como uno de los autores más prolíficos en cuanto a la literatura mexicana "de tema gay" se refiere. A lo largo de toda su extensa obra, la recreación del "personaje gay" ha provocado una verdadera apertura en las letras nacionales. No obstante, el autor podría ser famoso no solamente por su escritura de tópicos transgresores, sino por su formidable veta literaria que hace de sus textos lecturas regocijantes y, además, objetos innovadores en el plano estructural. Desde Hasta en las mejores familias (1975) hasta La historia de siempre ((2007), y pasando obviamente por el genial El vampiro de la colonia Roma (1979), la obra de Zapata posee un gran vigor en cuento al singular uso de diversos recursos literarios, los cuales, en este caso, están combinados de forma armónica con la diégesis. En otras palabras, historia y discurso van de la mano para crear un texto cargado de ingenio, chispa y humor.

Por otro lado, generalmente los grandes escritores "padecen" un grave problema en ocasiones con respecto a su público y a la crítica, y éste consiste en la gigantesca preeminencia de una obra sobre la demás. En consecuencia, es innegable que a Luis Zapata se le conoce como el autor de El vampiro... y se ha descuidado un poco la revisión de sus demás textos. ${ }^{252} \mathrm{Al}$ parecer, el éxito generado por esta novela resultó apabullante y “eclipsó” el resto de su obra. Igualmente, esto ha generado un desconocimiento de su labor cuentística -lo cual se debe también a la falta de la reedición de su volumen de relatos-, a pesar de que ésta posee un carácter muy original y, con frecuencia, apela a la creación de complejas estructuras narrativas.

\footnotetext{
252 Afortunadamente, a este respecto, Óscar Eduardo Rodríguez hace un espléndido estudio, como ya se mencionó oportunamente en el segundo apartado de este trabajo, de la creación del autor señalado, El personaje gay en la obra de Luis Zapata. Dicho estudio abarca en buena medida casi la totalidad de las novelas y cuentos del autor guerrerense, dado que el volumen se dedica a hacer un recorrido muy extenso por la eclosión del tema homoerótico en dichos textos.
} 
En "De amor es mi negra pena", la innovación en el campo estilístico está dada sobre todo por la mezcla extraordinaria de narradores heterodiegéticos y autodiegéticos, usando a la par un tiempo ulterior y simultáneo. Así, dividido en cuatro apartados de extensión diferente, el cuento condensa la precisión del artilugio cuentístico y la presencia de una historia infractora y, a la vez, convencional. En este sentido, el texto de Zapata brinda la correcta impresión de los modos más aterradores y destructivos en los cuales puede llegar a manifestarse el poder.

La historia del cuento en cuestión puede conectarse pues con la correspondiente a la del relato "Los amigos" de Juan Vicente Melo. Como podrá recordarse, en dicho texto el habitus cobra un temible y acostumbrado rostro: la automarginación y flagelación del sujeto a partir de la posible perspectiva abyecta tenida sobre sí mismo. De este modo, tanto los personajes del cuento de Melo como los pertenecientes al de Zapata, operan en un doble nivel discursivo en cuanto a representaciones sociales se refiere, es decir que oscilan entre el nivel de lo permisible y lo punible -y caen, irremediablemente, en esta segunda acepción.

"De amor es mi negra pena" crea un microuniverso textual en el cual tiene cabida la representación más acérrima del machismo mexicano. Los personajes, varones en su totalidad, habitan un mundo cargado de simbolismos que definen su vida y los hacen "actuar" de tal modo en determinada circunstancia. Nada lo que dicen, hacen, beben es gratuito, por lo contrario, está formulado con base en un código conductual anquilosado a la exacerbación de lo masculino. Salen a flote espacios típicamente dedicados al ámbito de los "hombres" como la cantina, los mingitorios, el fútbol o la milicia. Estos rubros son, paradójicamente, espacios velados y propicios para el contacto homosocial que, en ciertos momentos, puede contener el aspecto homoerótico jamás imaginado. Y es aquí donde Zapata pone el dedo sobre la llaga y explica cabalmente, a través de las secuencias de la historia colocada sobre 
la mesa, los modos en los cuales puede entenderse la masculinidad y la homosexualidad en México.

El protagonista del cuento, el Guacho es un "hombre" que forma parte de la milicia y posee un grupo de amigos con quienes juega futbol con frecuencia. A su vez, los lugares de convivio son las cantinas o pequeños prostíbulos en los cuales pueden defender su "virilidad" hasta el hartazgo o, por lo contrario, sucumbir ante los placeres ofrecidos por el contacto con otro individuo de su mismo "sexo". 253

El Guacho es una fuerza actancial tajante con respecto a los valores de la masculinidad y, en cierto modo, conlleva en esta actitud buena parte de su existencia; sin embargo, posee una "debilidad" ya advertida por el resto de sus compañeros: una sexualidad “disidente". Desde la primera línea del relato, uno de sus compañeros de cantina lo sentencia: "-Ha de ser puto -dijo uno de ellos-. Por eso siempre le paga todo". Esta palabra tan escueta y simbólica, tan detonadora y lastimosa, marca el universo narrativo y da al lector la pauta para comprender el resto de la historia.

El insulto "puto" aísla y margina a todo aquel sobre el cual cae la designación y coloca, en un plano de superioridad, a quien la emite. A partir de esta palabra peyorativa la creación de un escenario adverso es totalmente imaginable. Además, no hay duda de que este insulto remite a toda la visión del sistema patriarcal y, por supuesto, la exaltación del machismo de forma extraordinaria. A lo largo del cuento, el temor a caer dentro del campo semántico instaurado por dicha palabra está muy bien marcado y se convierte en una suerte de leitmotiv. Para el Guacho ser visto como "puto" implica una destrucción absoluta de su imagen $y$, a la vez, la pérdida del prestigio instalado sobre el resto de sus compañeros.

\footnotetext{
253 Las comillas usadas en este párrafo son para marcar la construcción cultural implícita en los términos en los cuales son usadas.
} 
Igualmente, como si de una competencia se tratara, los amigos que rodean al protagonista a cada momento crean un potente discurso de género en el cual intentan segregar mediante una grave violencia verbal a los otros; es decir que el resto de los personajes del relato buscan afirmarse en su "masculinidad" y "heterosexualidad" con el fin de denostar a los otros por un posible "afeminamiento" o, en su caso, deseo homoerótico. Por consiguiente, el dardo lanzado al inicio del texto sobre el Guacho ${ }^{254}$ genera una atmósfera complicada para este personaje, quien deberá sortear los diversos peligros creados por una disputa genérica y, claro está, heteronormativa.

Por otro lado, a la par que se desarrolla el repudio hacia lo otro a través del insulto, hay cierto regodeo en la misma circunstancia sexual del contacto homosocial: la intimidad instaurada por el espacio de la cantina es piedra angular de un escamoteo casi carnal entre cada uno de los personajes. Ciertamente, dentro de esta delimitación encausada solamente para los "hombres", la afirmación en la masculinidad puede ser un hecho llevado a tal grado que roza los límites con lo homoerótico. Así, el narrador tomando en cuenta este hecho, menciona lo siguiente: “Allí, la relación entre hombres parecía adquirir un matiz diferente. El aislamiento, o el alcohol, permitía ese trato íntimo que sólo bajo esas condiciones podía darse. Lejos (o no, pero igualmente protegidos) de la vista de las mujeres, podían profesar su amistad por otros hombres sin dar lugar a interpretaciones erróneas". ${ }^{255}$ Este énfasis en el hecho de encontrarse entre "iguales" crea una visión de cofradía, en la cual cada personaje

\footnotetext{
${ }^{254}$ Sobre el protagonista del cuento de Zapata, Rodríguez menciona: "La frase se refiere al Guacho, nombre que en México se usa para referirse a un soldado y en Argentina se utiliza como sinónimo de 'huérfano'. De esa frase, de lo que se sospecha de él, pende el hilo conductor de la trama y se puede decir que lo que al principio es una mera suposición, en el desenlace se torna en la comprobación de un hecho innegable; y en el final, el peso que ese hecho recién descubierto representa lleva al protagonista al suicidio”. Óscar Eduardo Rodríguez, El personaje gay en la obra de Luis Zapata, p. 185.

${ }^{255}$ Luis Zapata, De amor es mi negra pena (México: Posada, 1989), p. 79.
} 
siente en el otro cierta capacidad de empatía. La no proximidad con las "mujeres" fundamentaría también la sorpresiva irrupción del homoerotismo, situación que se encuentra muy cercana al ya reiterado tema de la prisión, donde cada sujeto justifica, mediante la ausencia de la "mujer", su cercanía sexual con cualquier otro recluso.

Cabe aclarar que este primer apartado del cuento lleva por título "Bajo la mesa", lo cual conlleva a pensar las diversos caminos de la sexualidad que, enfrascados en un ámbito de cantina, los personajes pueden tomar. En este sentido, es clara la alusión a la amistad frenética y pasional entre el Guacho y el "Botas", que es en cierto modo descubierta por el resto de los personajes a través del patrocinio frecuente del primero hacia el segundo. De este modo, la continúa queja del resto de los integrantes del grupo -y sobre todo de la actitud machista, hiriente y hostil del "Cuervo"- estriba en esta circunstancia y, de modo intermitente, en el hostigamiento hacia el Guacho para poner en entredicho su sexualidad. El señalamiento "Bajo la mesa" implica ese constante flirteo subrepticio que se realiza en la cantina e intenta ocultarse a los demás miembros del grupo de amigos, aunque este ocultamiento está más a flote de lo imaginado por el Guacho.

A lo largo del cuento entonces hay una ponderación muy dolorosa y apremiante del estatuto de género. Además, la apariencia lúdica que podría tenerse referente al hecho de "someter" o ejercer algún tipo de dominio y superioridad sobre los otros con respecto a cualquier muestra de afeminamiento, implica también una apuesta por jugar con dichas representaciones genéricas. Elsa Muñiz explica muy bien la construcción del cuerpo a partir de las premisas anteriores:

El hecho de que el cuerpo con género sea performativo indica que no tiene una posición ontológica distinta de los diversos actos que constituyen su realidad. La acción del género requiere, pues, de una 
actitud repetida, la cual consiste en volver a realizar y experimentar un conjunto de significados ya establecidos socialmente, y ésta es la forma mundana y ritualizada de su legitimación. Aunque existen cuerpos individuales que llevan a cabo estas significaciones al estilizarse en modos de género, esta acción es pública. Estas acciones tienen dimensiones temporales y colectivas, y su carácter público no deja tener consecuencias; de hecho, la actuación se efectúa con el objeto estratégico de mantener al género dentro de su marco binario, aunque no puede considerarse que tal objeto sea atribuible a un sujeto, más bien, que funda y consolida el género. 256

La continua reiteración de cada uno de los actos de los personajes del cuento con base en su visión del mundo implica una formación del cuerpo ajustada un exacerbado perfil del machismo dominante. Estar dentro de este "juego" crea un círculo hermético del cual resulta difícil desprenderse, ya que desde un principio cualquier aseveración sobre el ser "hombre" o "mujer" se transforma en axioma. En consecuencia, los personajes del relato de Zapata poco o nada pueden hacer contra este alienamiento, dado que la formulación del mismo recae en la repetición de la propia performatividad de sus estrategias de dominio. Esto trae a colación nuevamente la marcada forma del insulto, el cual se erige a modo de rotunda inapelabilidad. La heteronormatividad manifiesta su rostro más deleznable al "herir" a los demás a partir de la conformación de su propio cuerpo, es decir que el posible "error" o "anomalía" del sujeto insultado no está percibida fuera de él, sino en su propio interior:

Para ser considerado como perteneciente al conjunto de la no heterosexualidad, que es sinónimo de anormalidad, se requiere de la evidencia de tener un contacto sexo-sentimental con otro sujeto del mismo sexo. En ocasiones, también se echa mano de la perspicacia y de la acusación de quienes se encuentran en rededor y así se puede convertir a alguien en receptor de agresiones y de distanciamiento. Instituciones

256 Elsa Muñiz, "Del mito a la utopía. ¿Es posible una sociedad sin género”, en Mauricio List Reyes, et al, Florilegio de deseos (Puebla: BUAP, 2010), p. 119.. 
como la familia, la ciencia médica y la llamada justificia social han compartido elementos que sostienen en sus creencias inamovibles, y así en nombre del bien común y la salvaguarda del instigamiento hacia los cuerpos anómalos, los pensamientos que disienten y las formas de manifestación que se convierten en no gratas ante la mirada social que reprime e ignora la libertad sexual. ${ }^{257}$

Lo anterior aparece plenamente justificado en el cuento con el hostigamiento por parte de los amigos del Guacho y, a su vez, por el mismo personaje, quien sostiene a lo largo del relato una terrible lucha entre sus deseos y las "adecuadas" revelaciones del mismo.

Como ya se mencionó, el tema de la performatividad salta a la vista con la alusión a la idea de la conformación del cuerpo como algo dado desde siempre, y no desde la perspectiva histórica y social con la cual debería considerársele. El término permite una revisión de cada uno de los actos de afirmación del sujeto como una teatralidad detrás de la cual no se encuentra la supuesta "naturalidad" del género, sino un entramado simbólico de relaciones de poder bajo las cuales está sostenida la hegemonía del dispositivo de la sexualidad. Por tanto, la efervescencia del homoerotismo sólo es posible de soslayo, tal como lo señala el título del primer apartado del cuento y como sucede a lo largo del mismo. Si bien la relación entre el Guacho y el Botas es bastante clara desde el punto de vista del narrador, desde la perspectiva del resto de los personajes todo es advertido a través de la mordaz parafernalia del género y, por supuesto, con base en la cercanía entre ambos personajes que convienen "raramente" y, de algún modo, permanecen un tanto aparatados de los otros. En este sentido, "Bajo la mesa" es un continuo alarde de la fiesta represiva y, a la par, de la emoción producida por la súbita llegada del Botas, la preocupación por la lluvia que lo ha

\footnotetext{
257 Adriana Fuentes Ponce, “ ¿Acaso se puede tapar el sol con un dedo? La violencia como herramienta de estabilidad social”, en Mauricio List Reyes, et al., Florilegio de deseos, p. 229.
} 
mojado por parte del Guacho, el contacto furtivo y el encuentro incesante en el baño, que sin duda es momento más álgido y esclarecedor de dicho apartado:

Sus manos temblaban al tratar de desabotonar la bragueta. ¿Por qué? Con torpeza sacó su miembro y lo apuntó hacia el mingitorio. Temblaba. Su amigo había entrado y, mudo, se había recargado en la pared, a un lado del espejo. ¿Lo estaba observando? No podía orinar. Volvió a guardar su miembro y abotonar la bragueta. Volteó hacia el Botas, que parecía estar llorando (¿o sólo era la lluvia que aún le escurría?). Se miraron fijamente, sin decirse nada.

-Tengo miedo - exclamó finalmente el Botas, casi sollozando.

El Guacho (¿tal vez porque compartía esa sensación?) lo abrazó y dijo:

- Vamos a la mesa. ${ }^{258}$

El baño se convierte así en un subespacio dentro de la misma cantina: si ésta proporciona el aislamiento de las "mujeres" y una posible empatía entre "pares", el mingitorio acaba transformado de súbito en sitio que puede resguardar la sexualidad "abyecta" por excelencia. En este sentido, cada espacio puede tener otro dentro sí que puede servir para la eclosión de cierta "disidencia" que no podría darse dentro de un ámbito más público. Y aquí cabría preguntarse si el propio mingitorio de una cantina no es también un lugar público o si la intimidad está dada por el observarse, uno a otro, el falo al momento de orinar. Es evidente también que, en el caso del cuento, la cercanía no es producida desde el mismo instante del contacto en la cantina, sino que viene dada con anterioridad. El diálogo entre los dos personajes refuerza esta visión y amplía la sensación de estar en un ámbito "anormal”. El miedo expuesto por el Botas imprime este sello desolador, puesto que el personaje desea algo proscrito y comprende los alcances de dicha posibilidad al enfrentarse al resto de los

\footnotetext{
${ }^{258}$ Luis Zapata, Ese amor que hasta ayer nos quemaba, p. 87.
} 
personajes. Por otro lado, a su modo, el Guacho ofrece cierto cobijo, tal como lo hace en el plano económico, y trata de producir en el objeto de su afecto y deseo una mayor sensación de seguridad. Igualmente, el llamado "vamos a la mesa" permite advertir cómo la "actuación" frente a los demás estará dada por el encubrimiento de su relación, donde la única posibilidad de contacto: “-Órale -dijo, sentándose junto al Guacho, buscando nerviosamente su pierna. Cuando por fin la encontró, el Guacho no hizo ningún movimiento: sintió que su angustia se desvanecía", 259 y, más adelante, el lector encuentra: "Durante largo rato estuvieron jugando, sin poner atención a lo que hacían, cuidando sólo de colocar la ficha correspondiente. De vez en cuando fumaban, pedían otra cerveza, reían de algún chiste, bajaban la mano hasta la entrepierna para dar una posición más cómoda a su excitación”. ${ }^{260}$

Posterior a la eclosión del erotismo homosexual se produce inmediatamente una sanción. De este modo, el juego entre la hegemonía genérica y la disidencia sexual perdura con la enunciación del insulto, sólo que en este caso la denigración no proviene necesariamente del exterior, sino de la propia interioridad del personaje, quien se observa como un ser abyecto y, además, opera en él un grave conflicto con respecto a la representación de la "masculinidad":

Poco a poco la angustia, el asco quizás, volvió a invadirlo, y el querer alejarme de ti, ¿qué estaba haciendo?, es mi tormento, o peor aun, ¿qué estaba a punto de hacer?, no sé cómo vivir, ¿sería solamente un deseo momentáneo o se trataba de algo más serio?, no sé qué decidir en mi camino, que podría arruinar totalmente su vida, y si hay que terminar, junto con la del Botas, nuestra separación, ¿tendría que renunciar por completo a su identidad masculina?, será el destino, ¿a su tranquilidad futura?, sin embargo yo quiero, resignarse a ser señalado, que olvidemos las penas, a sufrir las burlas de todos sus

${ }^{259}$ Luis Zapata, Ese amor que hasta ayer nos quemaba, p. 88.

${ }^{260}$ Loc. cit. 
amigos, y me sigas amando, cuando no sus secreteos, aunque siempre vivamos, sus pensamientos, por dos vidas ajenas, y lo peor: lo que él pensara que pudieran pensar aunque no se lo dijeran, aunque siempre vi, resignarse a ser calificado, aunque siempre vi, aceptar el "puto", aunque siempre vi, el "joto," aunque siempre vi, el " de los otros", aunque siempre vi, el "del otro lado", aunque siempre vi, aunque siempre vi. $^{261}$

La reflexión en torno a la circunstancia del problema de la identidad se vuelve demasiado problemática, ya que el personaje observa en ella una profunda posibilidad denigratoria y, al a vez, no le encuentra un modo de escape sencillo. En otras palabras, el Guacho calcula los efectos que produciría en los otros la evidencia de su contacto homosexual con el Botas y, lejos de afirmarse en ella, llegan a su mente los insultos más socorridos por el resto de sus amigos. La lucha incesante entre el deseo y la prohibición del mismo alcanza un nivel muy severo y efectúa un irreparable daño en el personaje.

Después del apartado sobre la mesa se encuentra "El juego", un brevísimo capítulo en el cual hay un narrador en segunda persona que relata de modo simultáneo un juego de futbol y la entrada posterior al espacio de las regaderas por parte de todos los integrantes del equipo. Aquí, frente a la pelota, el Guacho trata de mantenerse al margen de cualquier deseo o culpa y se concentra únicamente en las posibilidades de ganar el juego y, a la par que éste avanza, esboza una posibilidad de situarse en un ámbito amorfo que le permita estar "libre" de cualquier observación por parte del exterior: "Te sientes otra vez tranquilo, otra vez como te gustaría ser siempre: en un momento. Sin un pasado, sin porvenir, sin cosas que hacer, sin cosas que no hacer, sin siquiera pensar, dejando a tu mente, como única actividad, la de registrar tus movimientos, tus sensaciones, sin que pueda intervenir otro elemento que juzgue

\footnotetext{
261 Idem., pp. 88-89.
} 
o censure o te lleve al error. Tú, así nomás. No hay que perder vista la pelota". ${ }^{262} \mathrm{Al}$ parecer, para el personaje estar en medio del campo de futbol es una actividad que puede mantenerlo al margen de cualquier provocación, insulto, pasión, desenfreno o flagelación; sin duda, éste es un espacio de absoluta libertad para el Guacho y puede concebir en el mismo una desmitificación de todo tipo de circunstancias ajenas a su cuerpo. A diferencia de la cantina, donde cada personaje está atento a los errores de los otros para acusarlo de "afeminado" y "puto", en la cancha cada uno está concentrado en el tablero y quedan a un lado los vituperios y el corsé genérico. Este hecho resulta paradójico en la medida en la que el futbol ha sido un anclaje rotundo de la masculinidad en México y Latinoamérica. En este caso, el narrador no apuesta tanto por el revestimiento simbólico del deporte en cuanto a sus connotaciones en un determinado habitus, por lo contrario, lo único que puede observar el lector es una obstinada fijación en la pelota sin percatarse de cualquier otra enajenación. No obstante, desde el mismo hecho de mencionar a este deporte se trae a colación toda una larga tradición de "masculinidad" al respecto y, como se había mencionado al principio del análisis del relato de Zapata, la presencia de la cantina, el militar y el fútbol no son gratuitas, puesto que adquieren una coraza simbólica impresionante al "atar" al Guacho a una identidad inamovible y fustigadora.

En continuidad con el ritmo del cuento, después de la presencia del protagonista en la cancha, pasa, con el resto de sus amigos, a los vestidores y, al igual que en el espacio del mingitorio de la cantina, late una claro erotismo homosexual cuando el Guacho contempla a los otros y se enfrenta a la mirada del Botas:

\footnotetext{
${ }^{262}$ Luis Zapata, Ese amor que hasta ayer nos quemaba, p. 90.
} 
Mientras se desvisten, tus compañeros y tú, y se limpian el sudor con las camisetas, vuelves a enfrentar la mirada del Botas: afiebrada, casi animal, casi latiéndole el corazón en ella. Te das cuenta de que siente lo mismo que tú. La angustia ha desaparecido para dejar paso una sensación de alegre cansancio, de aceptación, y te preguntas si podrías aceptar la amistad del Botas, su amor, a la vez entregándote, de la misma manera en que hace un momento te dabas al juego, sin preguntar nada, sin dejar que tus actos pasen por la conciencia, como un animal (¿como un niño?), dispuesto a gozar, como correr, las posibilidades que te brinda tu amigo, como patear la bola, dejándote arrastrar, como arrojarse al pasto, sin decir nada, como correr, sin dejarlo que hable, como patear la bola, sin dejarte que hables, como arrojarse al paso. ${ }^{263}$

Nuevamente la coyuntura de la entrega al deseo y la pasión por el Botas hace su aparición y, en cierto modo, es comparada con el mismo fervor usado por el Guacho para ganar el partido de futbol terminado hace un momento. Esta analogía es ampliada por el mismo personaje cuando establece un símil entre el mecanismo de seguir la pelota hasta la portería y el modo en el cual podría darse su encuentro con el "Botas. Además, puede esta situación puede ser percibida a través del crisol que ofrece la misma idea de estar en la chancha: permanecer inerte, sólo fijo frente a la pelota, alejado de cualquier enfrascamiento o dolor establecido por las propias pulsiones. Así, el Guacho imagina cómo sería su vida junto a su amado amigo si su relación tuviera las mismas posibilidades que un partido de futbol, sin mayores repercusiones que el obtener la victoria, y que en el caso de una relación afectiva será alcanzar la felicidad. Como se observa entonces, el oscilar entre los límites de lo deseo y lo punible permea todo el discurso del relato y, al igual que en buena parte de la literatura de corte homosexual, se transforma en un leitmotiv.

\footnotetext{
${ }^{263}$ Luis Zapata, Ese amor que hasta ayer nos quemaba, p. 91.
} 
El tercer apartado del cuento es un poco más extenso que el segundo y lleva por título "Celebración". Esta denominación tiene un plano simbólico innegable al igual que las dos anteriores, pero ¿para quién es la celebración y qué objetivo tiene en el cuento? Esta pregunta puede ser resuelta con la presencia de la victoria del juego de futbol recién acaecido, sin embargo, quedarse únicamente con esta conclusión sería algo profundamente arriesgado y simple. Desde otra perspectiva, esta "celebración" es para un dispositivo de género con la meta de violentar los deseos y fundamentar identidades hegemónicas. A lo largo de este capítulo, hay un narrador homodiegético que relata los hechos ocurridos en un pequeño prostíbulo, a donde acuden los amigos del Guacho con el fin de festejar su triunfo deportivo. Al principio, este personaje narrador señala cómo el Guacho y el Botas estaban sumergidos en una amena convivencia; pero el suceso más importante es la presencia de un mesero muy afeminado, que se convierte en el objeto de la burla $-\mathrm{y}$ deseo- de buena parte de los personajes: "Como casi todos los meseros de cantinas (como casi todos los meseros), también era joto, pero en él su amaneramiento no resultaba tan chocante; quizá porque era joven y rubio y de facciones delicadas; quizá porque, en un descuido, uno podía pensar que se trataba de una muchacha". ${ }^{264}$ Cabe destacar de esta cita la relación entre la "naturalidad" en la línea sexo/género/deseo: el narrador señala que el mesero era menos fastidioso, en cuanto a su "femineidad" se refiere, por sus características corporales -la juventud, el ser delicado y rubio- muy cercanas a lo que, en términos de determinaciones genéricas, podría ser definido como una mujer. La linealidad queda articulada a partir de la relación entre los rasgos físicos y las correspondencias simbólicas enclaustradas en el dispositivo del poder.

\footnotetext{
${ }^{264}$ Luis Zapata, Ese amor que hasta ayer nos quemaba, p. 93.
} 
Por otro lado, y una vez que le mesero es invitado a sentarse en la mesa de los amigos del Guacho para "conversar" un momento y hacerlo objeto de halagos burlones, se inicia nuevamente el juego con el cual se pretende destruir el prestigio de los otros con base en una posible "disidencia sexual". No obstante, este juego es tan complejo y, a la vez, tan demoledor también para quien lo efectúa que los propios alabadores/detractores del joven mesero sucumben a su belleza, aunque lo niegan firmemente: "Cuando desperté, el mesero ya estaba sentado con nosotros, y reía, aunque tímidamente, de las bromas que hacían el Cuervo y el Rengo. El Cuervo, que si nunca le habían dicho que era muy bonito, que de tan bonito parecía mujer, tómate otra copa, que a ver, que viniera, que se le acercara más, y él, temeroso, se acercaba, que no tuviera miedo, que al Cuervo no le gustaban los putos, que nomás quería verlo". ${ }^{265}$ Obviamente, en todo este flirteo lo que sale a flote es la negación y, a la vez, participación en el homoerotismo; el Cuervo, sin necesidad de que se lo pregunten, señala su "heterosexualidad" pero, casualmente, resulta atraído por el joven mesero: "Que miraran, ahora el Rengo, abrazándolo y metiéndole mano por atrás, que tenía nalgas de vieja, y luego el Cuervo, por debajo de la camisa, hasta chichitas tiene". ${ }^{266}$ Esto plasma cómo la efervescencia de una masculinidad llevada al límite en un contacto homosocial conlleva al mismo ámbito homoerótico: la cantina es, por segunda ocasión, el lugar para explayarse y demostrar ante los otros la "hombría", aun a costa de señalar el propio deseo por lo "negado". $\mathrm{Al}$ respecto de esto, Óscar Eduardo Rodríguez anota con certeza lo siguiente: “En mi opinión, el cuento deja expuesta la homosexualidad latente de los personajes en contraposición con su propia actitud homofóbica", ${ }^{267}$ y, ahí mismo, concluye: "Esto evidencia una contradicción

\footnotetext{
${ }^{265} \mathrm{Idem}$, p. 94.

266 Loc. cit.

${ }^{267}$ Óscar Eduardo Rodríguez, Elpersonaje gay en la obra de Luis Zapata, p. 197.
} 
en la posición que los personajes guardan respecto a esa orientación sexual, porque, por un lado, se permiten juegos extraños que, disfrazados de machismo, pretenden ser muy divertidos y, por el otro, señalan y vituperan a uno de sus compañeros a quien el juego o la broma lo pone en una situación de conflicto existencial" ${ }^{268}$ Esto último queda muy claro ya que lleva al lector al trágico desenlace del cuento: mientras todos flirtean sin mayor problema con el mesero, buscan incisivamente dejar en evidencia la posible "homosexualidad" del Guacho, a quien ya han abatido constantemente con los juegos. En consecuencia, la “celebración" del apartado consiste en denostar a este personaje con base en su "disidencia sexual" y, para lograr este fin, la presencia del mesero resulta certera. Así, después de "jugar" un rato con el joven, el Cuervo le pide que le exprese quién le gusta más, a lo cual el primer personaje responde que el Guacho. Esta circunstancia coloca en el filo de la navaja al protagonista, dado que, como bien lo expresa, participar o no participar del juego conlleva la misma consigna: "decir que era puto". ${ }^{269}$ Por tanto, el Guacho cae en el juego y, debido a su propio deseo y la desinhibición provocada por el alcohol, termina excitado ante la presencia del mesero:

Entonces el Guacho como que se sintió en confianza y le agarró las piernas, se las empezó a sobar. Todas las miradas, divertidas, seguían la mano del Guacho para ver a qué hora se iba a delatar. De repente, por estar viendo su mano (que después, rodeando su cintura, había llegado hasta las nalgas) nos olvidamos de él, hasta que el Cuervo, con una expresión de triunfo, dijo, casi gritando: "miren, ¡es puto!, ¡tiene la verga bien parada!", y el Rengo "ora sí ya se supo, pinche puto", y el Guacho levantándose y dándole de madrazos al Cuervo, hasta tirarlo al suelo; y después, ya se iba contra el Rengo cuando el Botas lo detuvo: "déjalo", gritó, como si le ordenara, en una forma en que nunca lo habíamos oído gritar, "no

\footnotetext{
268 Loc. cit.

${ }^{269}$ Idem, p. 95.
} 
vale la pena”, sujetándolo de un brazo, “¿no ves que eso es lo que quieren?”, y el Guacho al Botas "quítate", apartándolo con un golpe, "pinche maricón, hijo de la chingada", y le volvió a pegar, haciéndolo caer sobre la mesa (el Botas no se defendió). El Guacho, limpiándose las manos en el pantalón, y dejándonos con la cuenta, salió del lugar. ${ }^{270}$

La cita delata la furia del Guacho experimentada ante el asedio de los demás y, paradójicamente, ante el intento de apoyo por parte del Botas: la situación es llevada a tal límite -aunado el temor por parte del protagonista sobre el descubrimiento de su "identidad sexual"- que el mismo objeto amoroso se convierte en el sitio también de los golpes y de los improperios. Justo en esta parte es donde la diégesis crea el preámbulo para el final: la furia del Guacho es la primera evidencia severa del desenfreno del mismo y demuestra, a su vez, el abigarramiento, en la mentalidad del personaje, de una visión de género anclada a una masculinidad punzante y una heternormatividad imposible de eludir. La defensa de los demás por causa del insulto opera como un "reflejo social" y dota a esta arma verbal de una mayor capacidad de daño. ${ }^{271}$ La "celebración", por tanto, ha sido concluida de forma satisfactoria: el Guacho ha quedado "evidenciado" ante los otros como "puto" y su masculinidad ha sido puesta en entredicho, igualmente, el poder del dispositivo de la sexualidad muestra su rostro

\footnotetext{
${ }^{270}$ Loc. cit.

271 Sobre la forma del insulto como instrumento para crear daño y coaccionar a los demás al respecto de sus actos, Adriana Fuentes menciona: "En la infancia, la adolescencia, el colegio, las amistades, el trabajo y el club, por mencionar sólo algunos espacios, podemos darnos cuenta de que el término utilizado para agraviar, degradar y someter a aquel sujeto hombre que evidencia su carencia de imagen y actuación como 'hombre' es la injuria, al utilizar términos como: maricón, puto, puñal, marica, mandilón, vieja... Sea a viva voz, públicamente o al oído, en cualquiera de los casos la intención es que olvide ciertas actitudes que lo ubican como 'no hombre'. En circunstancias cotidianas, los disgustos o pleitos en diferentes edades suelen albergar estas palabras, la aplicación de las mismas en los regaños familiares tiene el objetivo de la afectación directa a la persona": Adriana Fuentes Ponce, “¿Acaso se puede tapar el sol con un dedo? La violencia como herramienta de estabilidad social”, p. 236.
} 
más agresivo al destruir no sólo el "prestigio" del personaje, sino al desgarrar introspectivamente cualquier deseo del mismo.

El último y cuarto apartado del cuento, "En el baño" es la eclosión definitiva y severa de todas las posibilidades de daño efectuadas desde la imposición de la "matriz heterosexual". Nuevamente un narrador heterodiegético y de forma simultánea relata el

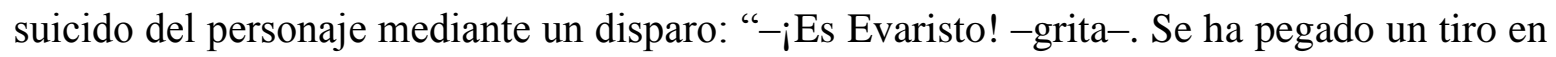
el baño -casi enloquecido". ${ }^{272}$ Con este diálogo final queda marcada herméticamente la desaparición del protagonista; ${ }^{273}$ a su vez, el lector descubre el nombre del Guacho y este guiño del discurso narrativo delata la posibilidad performativa y de interpelación inscrita detrás de la palabra, ya que a lo largo de todo el cuento siempre se había usado el sobrenombre del protagonista para señalarlo y, ahora, al final, se conoce su verdadero apelativo. Sin duda, este recurso permite al lector advertir cómo se construye una dualidad sobre el personaje del mismo modo en el cual el discurso ha ido sorteando la oscilación entre el ámbito de la "disidencia" y la normatividad. Por otro lado, puede funcionar también para sellar simbólicamente la construcción de una identidad con base en los factores ajenos y propios del individuo para devenir sujeto: el nombre queda entonces no sólo como una palabra para llamar al otro y ser reconocido, sino como una "marca" que crea la misma conducta del hombre a partir del contacto con el plano de lo simbólico.

\footnotetext{
272 Idem, p. 97.

${ }^{273}$ Mario Muñoz, al analizar el texto de Zapata aquí estudiado anota lo siguiente: "Considerada en estos términos, su homosexualidad [del Guacho] tiene efectos tan contundentes como si se tratara de una carencia tan grave como la impotencia o la castración. El desenlace del relato es entonces consecuente con la agresividad propia del macho, esta vez vuelto contra sí mismo. El hallazgo de Luis Zapata es hacer coincidir en un solo sujeto dos impulsos opuestos con igual poder de anulación sin mediar ninguna escapatoria". Mario Muñoz, De amores marginales, p. 30. Y, efectivamente, "De amor es mi negra pena" muestra nuevamente la cara más destructiva de la hegemonía del género y la sexualidad; además, proporciona una clave para entender las copiosas manifestaciones de la tragedia en la literatura de tema homoerótico.
} 
Cuestionamiento (1991-2011)

La publicación de Amores de segunda mano en 1994 fue para Enrique Serna uno de los hechos más afortunados en su trayectoria como escritor. Este volumen de cuentos se ha convertido en un auténtico clásico de la literatura mexicana contemporánea: varios de los textos ahí reunidos han aparecido en antologías altamente difundidas y, otros más, han sido objeto de estudio por parte de la crítica. Pudiera parecer que este libro debe su éxito a los inusitados temas trabajados por Serna; sin embargo, la cuestión no queda solamente en este aspecto. Sin duda, el gran acierto del autor fue la mezcla heteróclita y afortunada de tópicos recalcitrantes y estilo innovador, lo cual es fácil de advertir en el cuento que será analizado aquí: "Amor propio". En este texto resalta, en el plano diegético y en el del discurso, la visión de la otredad y, por supuesto, la dualidad que ésta conlleva. El lector acude una concepción binaria -esto no necesariamente implica restricción o inamovibilidad- del hombre como sujeto culturalmente construido, cuya base se halla en la representación de dos identidades en apariencia diferentes, hombre/femenino y mujer/masculina, pero cuya mezcla produce un suceso explosivo, con la debida reserva que el uso de esta palabra implica en un trabajo como éste.

En cuestiones discursivas, "Amor propio" posee una estructura cuya ruptura es inmediatamente percibida por el lector. Se trata de un cuento en el cual los signos de puntuación prácticamente son inexistentes, excepto por la presencia de los puntos finales en los tres párrafos que conforman el cuerpo del texto. Esta transgresión recuerda a una de las novelas emblemáticas de la tradición literaria mexicana homoerótica: El vampiro de la 
colonia Roma de Luis Zapata. Como es bien conocido, este discurso narrativo está escrito bajo la premisa de evitar los signos de puntuación y hacer del acto de contar un suceso absolutamente fluido y relacionado con la oralidad. En la novela de Zapata, este hecho está justificado por cuestiones diegéticas que saltan al ámbito discursivo: la presencia de una grabadora a la cual el narrador-protagonista relata los acontecimientos más importantes de su existencia. Ahora bien, en "Amor propio" no hay una justificación aparente del hecho con base en un recurso de la historia bien definido; por el contrario, es evidente la libertad que puede tener el lector para interpretar dicho asunto, la cual puede sintetizarse, de forma general, en dos motivos: 1) la abrumadora presencia del alcohol a lo largo de la diégesis y 2) la alteración del discurso patriarcal y heteronormativo. Con base en estas dos premisas es posible consolidar una visión más clara de esta circunstancia y comprender cómo la transgresión del discurso está puesta en una amalgama con el plano diegético.

Aparte de la ruptura establecida con respecto a la puntuación del texto, otra cuestión discursiva de suma importancia es la presencia de dos narradores cuya diferenciación es complicada, mas no imposible, en algunos fragmentos. La alternancia repentina de las voces narrativas es un acierto más del texto y produce, en el lector, una visión con dos enfoques diferentes, pero cercanos en cuanto una cuestión espacial, sobre el mismo hecho. De este modo, se crea en el cuento una visión de simultaneidad que podría coincidir con un recurso cinematográfico llamado montaje o edición en paralelo, cabe mencionar aquí que una de las protagonistas del cuento es una actriz y cantante de telenovelas; indudablemente, esta coyuntura permite una proximidad con un discurso audiovisual.

Estos elementos del discurso ponen en la mesa el tema de la posmodernidad en el ámbito de los recursos usados por la literatura. Sin duda, El vampiro de la colonia Roma y 
"Amor propio" apelan a este paradigma en la medida de la deconstrucción realizada tanto sobre asuntos discursivos como diegéticos. Al respecto, Elena M. Martínez menciona:

Por literatura posmoderna se entiende aquí las formas de representaciones sociales, estéticas y políticas. Entre los rasgos sobresalientes de esta literatura posmoderna que se empieza a producir en la década del sesenta están heterogeneidad, la tendencia hacia lo antihegemónico, el cuestionamiento de la capacidad representativa, la presencia de lo lúdico, lo marginal, un ataque al concepto de las verdades absolutas, un impulso paródico, la representación del género sexual como acto performativo y la desestabilización de las fronteras de los géneros literarios. ${ }^{274}$

Esto es claro en el cuento en cuestión, dado que el lector se enfrenta al desmantelamiento de los conceptos de género, sexualidad, matrimonio e identidad fija dispuestos como verdades absolutas por el dispositivo del poder. Así, el cuento aborda el tópico clásico del enfrentamiento entre la homosexualidad y la heterosexualidad, pero desde una perspectiva profundamente desestabilizadora para ambas representaciones.

Como se dijo al inicio del estudio de "Amor propio", en este cuento subyace de modo efervescente el tema de la dualidad; sin embargo, como también ya se mencionó, esta concepción binaria no es, para nada, un artefacto fijo. Así, en el texto conviven dos personajes de diferente "sexo", Roberto y Anastasia Gutiérrez, que representan, de forma similar, a un tercer personaje, Marina Olguín. El siguiente cuadro puede expresar mejor esta circunstancia:

\footnotetext{
${ }^{274}$ Elena M. Martínez, "Género y posmodernismo: intención paródica en el El amor es una droga dura de Cristina Peri Rossi", en Dieter Ingenschay, et al, Desde aceras opuestas. Literatura / cultura gay y lesbiana en Lationamérica, p. 209.
} 


\begin{tabular}{|l|l|l|}
\hline Identidad base & Roberto & Anastasia \\
\hline Identidad representada & Mariana Olguín & Mariana Olguín \\
\hline
\end{tabular}

Como se observa, la identidad "base" -más adelante se explicará este concepto- es completamente "diferente" en cada uno de los personajes del cuento, es decir que, para el habitus mexicano, Roberto y Anastasia serían dos entidades perfectamente bien diferenciadas a partir de su cuerpo y de la lectura establecida para éste. Por otro lado, de modo parcial, podría entenderse que las entidades cuyo nombre es el mismo, Mariana Olguín, son una sola $\cos a$; no obstante, en el universo del cuento, cuya alegoría ataca los fundamentos del dispositivo de género mexicano, esto es totalmente opuesto. De este modo, el texto de Enrique Serna lanza un alegato en contra de la imposición de una determinada identidad por parte de un aparato de poder.

En principio, Roberto y Anastasia, por cuestiones relacionadas con una cotidiana visión del género y de la sexualidad, serían dos personas totalmente distintas: el primero tendría que representar la visión de un "hombre" y, la segunda, seguiría la causa de ser “mujer”. Colocar la definición de género entrecomillada no es algo gratuito; al contrario, con esto se pretende aludir a las características culturales con las cuales se advierte la formación de las mismas. Así, se tiene dos entidades bien diferenciadas: el cuerpo y aquello que, con base en una visión de la colectividad, se tiene por el mismo y a partir de lo cual se va construyendo: "El género es por lo tanto la investidura de significados que en cada sociedad concreta asume el sexo biológico, el cual se toma en principio como dado. El sistema sexo/género es el proceso o mecanismo por el cual se transforma a machos y hembras de la especia humana en hombres y mujeres socialmente adaptados a la división de papeles que la 
sociedad establece entre ellos". ${ }^{275}$ Roberto y Anastasia brindarían, al interior del texto, una apuesta bien definida por esta cuestión binaria del género tan amada por la sociedad mexicana; sin embargo, la inestabilidad de la misma es rota cuando el cuerpo de cada uno de ellos no se sujeta, de modo arbitrario, a la definición dada por su entorno. Cabe resaltar el poder del cuerpo por sí mismo y no a través de una circunstancia externa: antes que nombres y sujetos, Roberto y Anastasia son corporalidades cuya principal característica estriba en un principio de libertad. Es muy importante esta situación en el cuento, ya que con ella inicia una crítica subrepticia hacia esta capacidad de una sociedad dada para construir sujetos a partir de cuerpos. Los dos personajes, antes de ser otro, en el espacio del texto son ellos mismos. Esto implica una verdadera ruptura más allá de una clásica oposición entre dos sistemas de deseo, uno soterrado y otro prestigiado.

Roberto, como personaje-narrador, menciona cómo se produjo este cambio de una situación de identidad y de deseo impuestas a un ámbito de libertad: "Roberto el beisbolista su retiro de los diamantes por culpa de jardinero izquierdo el cátcher y el short stop que me dieron pira en un terreno baldío". ${ }^{276}$ La alusión es directa y clara al descubrimiento de la homosexualidad y la desavenencia con ámbito de lo masculino. En este caso, el béisbol connotaría un espacio dedicado a los "hombres" y, por ende, a la virilidad. El "retiro" es, obviamente, una salida de este sitio para colocarse como ser en sí mismo en un entorno diferente: un audaz travesti que imita, en un bar gay, a Marina Olguín, una famosa actriz y cantante de telenovelas. Se tiene aquí un paso de una especie de una identidad hermética a una más laxa, adquirida con base en las decisiones del individuo.

275 David Córdoba, “Teoría queer: reflexiones sobre sexo, sexualidad e identidad. Hacia una politización de la sexualidad", en Teoría queer. Políticas bolleras, maricas, trans, mestizas, p. 35.

276 Serna, p. 134. 
El caso de Anastasia es muy diferente al de Roberto: no hay un poder de decisión que tome como base aquello que el personaje desea; al contrario, la transformación de Anastasia en Marina Olguín ocurre a partir de una circunstancia mercadológica: "Tampoco yo soy Marina estúpida mi nombre verdadero es Anastasia Gutiérrez a Marina Olguín la inventó el director de Corazones sin destino Corazones sin rumba corrigió ella". Como puede observarse, el hecho en este caso es devastador y con una alegoría muy profunda en cuanto a la visión del poder económico como creador/impulsador de identidades.

Roberto y Anastasia, padecen, a su modo, la hegemonía del poder a partir de una condición social/genérica y una necesidad económica/clasista, que, a final de cuentas, poseen el mismo fundamento. Los cuerpos de los protagonistas son revestidos con una condición diferente a la necesaria según las propias convicciones de los mismos, pero esto no ocurre de forma paralela, sino en un plano inverso: Roberto altera y destruye las características genéricas instituidas a partir de su cuerpo de varón para convertirse en un travesti, Mariana Olguín; y Anastasia es forzada a cambiar su nombre identidad con la finalidad de adquirir el renombre, éxito y remuneración proporcionadas por otra Mariana Olguín, lo cual constituye similarmente un travestimiento. Así, como se había anotado algunos párrafos atrás, los dos personajes en una primera lectura pudieran parecer diferentes; sin embargo, mirándolos con mayor detenimiento constituyen una cercanísima alegoría que conlleva la deconstrucción del sistema sexo/genérico. Por tanto, Roberto y Anastasia, antes de ser incluso ese nombre que los llama y determina, son cuerpo, cuyo principal rasgo es que desea y vulnera los límites de la demarcación extrínseca: ser hombre, ser homosexual, ser mujer, ser producto del mercado televisivo, ser objeto de deseo. Esto significa una apertura hacia las diferentes posibilidades tenidas por el cuerpo para transformarse en cualquier cosa, la única problemática en este caso 
es la hegemonía impulsada por las representaciones heteronormativas, patriarcales, clasistas y racistas. Al respecto, Ricardo Llamas menciona:

Estamos, pues, ante la articulación de un "régimen de la sexualidad" como sistema relativamente coherente de organización de toda una serie de criterios a partir de los cuales se construyen se realizan y se interpretan las relaciones afectivas entre las personas y las prácticas corporales placenteras, y a partir de los que se establecen sus implicaciones en todos los órdenes de la vida social. El régimen de la sexualidad que se establece en Occidente está determinado por discursos y prácticas que emanan de instancias de poder, o que las hacen emerger como tales, en unas sociedades y en un momento histórico determinados. [...] Desde un punto de vista materialista, cada modo de producción (en este caso el capitalista) conlleva un orden sexual específico que determina cómo se distribuyen los deseos y los placeres de acuerdo con un sistema particular de organización de la producción y la reproducción. ${ }^{277}$

El dolor producido por esta determinación a partir del "régimen de la sexualidad" estalla en el cuento con la visión de dos deseos enfrentados y, por tanto, dispares. Debe recordarse aquí que Anastasia está en el puerto de Veracruz grabando una telenovela; durante su estancia en dicha ciudad, sus amigos le suplican que los acompañe a un bar en el cual se presenta un travesti quien la imita, en su representación de Marina Olguín, con gran "exactitud". Esto ocurre también por el deseo de estos mismos amigos de sacarla de una supuesta depresión, la cual la ha mantenido encerrada en el cuarto del hotel desde su arribo a la cuidad. Una vez que Anastasia es llevada y acude al lugar donde sus amigos la conducen, observa con mucha curiosidad, pasión y morbo la presentación de Roberto en el papel de Marina Olguín. Por otro lado, Roberto, ante la noticia de que en el bar está presente Anastasia padece un auténtico

\footnotetext{
277 Ricardo Llamas, Teoría torcida. Prejuicios y discursos en torno a la "bomosexualidad" (Madrid: Siglo XXI, 1998), p. 11.
} 
ataque de nervios: "Cuando Gertrudis el mesero me dijo que Marina Olguín la verdadera Marina Olguín acababa de llegar al Marabunta Club acompañada de dos caballeros [...] pero antes de salir a escena eché un vistazo por la rendija de bastidores y al descubrir que Gertrudis no mentía las piernas me temblaron de miedo a que Marina hubiera venido a burlarse de mí pues traía puesto el mismo vestido que yo usaba en el número". ${ }^{278}$ Debido a la presencia de Anastasia, Roberto exacerba la actuación que realiza de Marina y termina cautivando a la primera, quien no sólo advierte el poder histriónico y capacidad vocal del personaje, sino que comienza a manifestar el deseo de un posible encuentro sexual entre ambos, esto último es fácil de deducir a partir del insistente coqueteo y acercamiento por parte de Anastasia. Posteriormente, ésta invita a Roberto a la habitación de su hotel, en el cual Anastasia promete varias cosas al primero a cambio de un encuentro erótico.

El enfrentamiento entre ambos personajes se produce en esta ansiada relación sexual por parte de Anastasia y profundamente rechazada por Roberto. Esta situación extraña genera una escena una escena poco convencional, pero muy bien articulada por la voz de los dos narradores del cuento:

Me perdió creí en sus promesas y aprovechando este titubeo la empujé sobre la cama nos enredamos los brazos y las piernas rompí los botones de su vestido creí que se desilusionaría cuando quedó al descubierto la prótesis de mis senos pero su perversidad no tenía límites me desagarró el brasier y besé mi plexus solar cuidadosamente rasurado canta me pido canta te digo y su voz fue la rúbrica de nuestro amor es lo más bello del mundo nuestro amor era lo más grande y profundo porque trascendía la posesión superficial que sólo reafirma la separación de los cuerpos era la posesión total gestando una nueva persona yo tú ella dotada de senos testículos clítoris en la manzana de Adán cuatro dieciséis sesentaycuatro ojos mirándose mirar a la contorsionista que chupaba su propia verga subía en ella y se

${ }^{278}$ Serna, p. 133. 
cabalgaba convertida en un monstruo bicéfalo canta Marina canta gemía mientras su inmunda zanja devoraba mi sexo vendido en aras del éxito profesional canta Marina canta mamacita padrote puta dame la encarnación. ${ }^{279}$

Es de notar en esta cita la transgresión realizada al menos en tres niveles: 1) la mezcla heteróclita de genitales de hembra y varón como si constituyeran un mismo cuerpo, 2) la imagen de dos mujeres en un acto sexual y, más allá de esta circunstancia que sería convencional hasta cierto punto, la presencia del juego del travestimiento de ambos y 3) el carácter sacrílego adoptado por parte de Anastasia para denominar el encuentro sexual con Roberto. La combinación de estos tres rasgos realiza una "herida" grave al dispositivo de la heteronormatividad y el patriarcado. El mero hecho de la enumeración de los genitales de forma abrupta y sin una aparente organización genera la idea del hermafrodita, cuyo solo acotamiento hace estremecerse al sistema de género Occidental, tan anclado en una visión binaria y bien "definida" de lo correspondiente a uno y otro "sexo". El hermafrodita trastrueca por completo las bases de esta dicotomía y su correcta separación al aglutinar, en un único cuerpo, las características correspondientes a la separación "lógica" de las representaciones sociales del "ser hembra" y "ser varón”. Nuevamente esta idea coloca al lector ante una perspectiva cercana entre Roberto y Anastasia, ya que serían corporalidad en estado "puro" a lo largo de su encuentro sexual.

El segundo elemento transgresor que se mencionó en el párrafo anterior es el relacionado con el observar una escena en la cual dos "mujeres" sostienen un encuentro sexual. Aquí es importarte recalcar la ya clásica definición del género, según la cual éste concepto apunta hacia el caparazón cultural dado a las características fisiológicas de la

\footnotetext{
${ }^{279}$ Serna, p. 139.
} 
diferencia sexual; puesto que, tomando como base la definición del ser humano a partir de su identificación con uno u otro género, lo advertido en esta parte del cuento es un acercamiento erótico entre dos cuerpos cuya representación apunta hacia lo femenino. ${ }^{280}$ Sumado a esta visión de ruptura, está la alteración de los roles como activo y pasivo, cuya correspondencia está con el "ser hombre" y "ser mujer". La sociedad mexicana y, en general, la tradición judeocristiana determina el ámbito de la sexualidad femenina al resguardo de una actitud pasiva, es decir que la mujer no puede afirmarse como un sujeto deseante, al contrario, sólo puede ser vista y construirse como un objeto de deseo. Por otro lado, al hombre correspondería una actitud marcada por un halo de actividad y decisión, mediante el cual puede asumirse con un ser eminentemente sexual y con la capacidad de objetivar a lo femenino. Estas dos posturas están determinadas por una visión del falo y la vagina como órganos de superioridad e inferioridad correspondientemente; sin embargo, en "Amor propio" acontece una operación contraria: lejos de ser Roberto quien determinaría la relación sexual, es Anastasia quien la domina y, a su vez, el primero refiere cómo ésta "devoraba" su miembro, lo cual implica una supeditación del personaje "masculino"281 en el ámbito sexual. A la par de esta circunstancia, Anastasia llama a Roberto como "mamacita padrote puta", esta determinación sin duda crea la idea de amalgama con respecto a los roles genéricos, y

280 Debe mencionarse además que los cuerpos de Roberto y Anastasia está cubiertos por una vestimenta que, aparte de corresponder con lo "femenino", es la misma: el vestido usado por el primero para la interpretación del papel de Marina Olguín es "igual" al portado por Anastasia. Un comentario al respecto de este curioso detalle se realizará algunos párrafos más adelante.

281 Una novela que aborda magistralmente esta perspectiva, es El lugar sin límites (1966) de José Donoso. En dicho texto un hombre travestido, la Manuela, es "seducido" por una mujer, la Japonesa, quien lleva también el control de un furtivo encuentro sexual. Al respecto, Mark Millington menciona lo siguiente: "Durante sus relaciones sexuales la Japonesa asume el rol dominante, refiriéndose a ella misma como "la macha" y a Manuela como "la hembra" y así disocia los roles varón/hembra de todo vínculo automática con la identidad sexual física. Y es significativo que el interés sexual de Manuela se despierte sólo cuando la Japonesa toma este rol dominante de "la macha". Hombres in/visibles. La representación de la masculinidad en la ficción latinoamericana, 1920-1980 (Bogotá: FCE, 2007), p. 291. 
les otorga un carácter movible y placentero, según sea el caso. Por lo tanto, el uso del nombre adquiere un poder de anclaje para el sujeto interpelado, quien permanece designado siguiendo una oposición muy remarcada: ser al mismo tiempo un individuo dominante y dominado.

El último elemento de esta triada de transgresión está relacionado con el carácter sacrílego dado por Anastasia, quien pide a Roberto que le proporcione la "encarnación", concepto relacionado claramente con un acontecimiento bíblico. En Amores de segunda mano este hecho resulta muy cotidiano, puesto que las diégesis de varios cuentos o, al menos, en alguna parte del discurso, se menciona un rasgo cuya repercusión está directamente referida con una sanción al discurso religioso imperante en México. El ejemplo más claro de ello es "Extremaunción", cuento en el cual un sacerdote cobra venganza a través del revestimiento simbólico y físico perturbador dado a un sacramento. Algo similar ocurre, aunque en un menor grado de sacrilegio, en "El desvalido Roger" y "El coleccionista de culpas", textos en donde se alude a un cuestionamiento del concepto de piedad y pecado correspondientemente.

Una vez anotadas las características transgresoras del acontecimiento sexual entre Roberto y Anastacia, sería bueno recuperar el concepto de identidad anotado casi al principio del análisis del cuento. En el cuatro acotado aparecen dos tipos de identidad, base y representada, los cuales se relacionan no con una visión intrínseca de la conceptualización del discurso sobre el cuerpo, sino con el proceso de adquisición de un determinado revestimiento genérico. Roberto es "hombre" debido a una cuestión biológica enfatizada de modo voraz por el dispositivo del género y la sexualidad; lo mismo ocurre con Anastasia. Puede decirse entonces que ambos personajes poseen esta identidad base no necesariamente como lo deseado, sino como lo demarcado por una instancia de poder para su cuerpo. Por otro lado, la identidad representada es aquella desprendida totalmente de la inicial. Como ya 
se mencionó, Roberto es Marina debido a un proceso placentero que lo llevó al descubrimiento de su homosexualidad y el goce en el travestimiento; Anastasia es Marina por un una mera causa de mercado en buena medida dolorosa para el personaje. Así, estos dos tipos de identidad ponen en entredicho el mecanismo de naturalización de la misma y aluden innegablemente al famoso concepto de performatividad, puesto tan en boga por Judith Butler y, en general, por todos los seguidores de la teoría queer:

No obstante, cuando se entiende la identificación como una incorporación o fantasía hecha realidad queda claro que la coherencia es anhelada, esperada e idealizada, y que esta idealización es efecto de una significación corporal. En otras palabras, actos gestos y deseo crean el efecto de un núcleo interno o sustancia, pero lo hacen en la superficie del cuerpo, mediante el juego de ausencias significantes que evocan, pero nunca revelan, el principio organizador de la identidad como una causa. Dichos actos, gestos y realizaciones -por lo general interpretados- son performativos en el sentido de que la esencia o la identidad que pretenden afirmar son invenciones fabricadas y preservadas mediante signos corpóreos y otros medios discursivos. [...] Esto también indica que si dicha realidad se inventa como una esencia interior, esa misma interioridad es efecto y una función de un discurso decididamente público y social, la regulación pública de la fantasía mediante la política de superficie del cuerpo, el control fronterizo del género que distingue lo interno de lo externo, e instaura de esta forma la "integridad del sujeto". En efecto, los actos y los gestos, los deseos organizados y realizados, crean la ilusión de un número de género interior y organizador, ilusión preservada mediante el discurso con el propósito de regular la sexualidad dentro del marco obligatorio de la heterosexualidad reproductiva. Si la "causa" del deseo, el gesto y el acto puede situarse dentro del "yo" del actor, entonces las regulaciones políticas y las prácticas disciplinarias que crean ese género, presuntamente coherente, en realidad desaparecen. ${ }^{282}$

282 Butler, p. 45. 
De este modo, las cuatro identidades surgidas -Roberto, Marina Olguín (Roberto), Anastasia y Marina Olguín (Anastasia) - son el producto de esta capacidad performativa que posee el hombre para dotar de significados a su propio organismo. La alegoría mostrada por Serna constituye un verdadero giro queer en cuanto a la concepción del género, la sexualidad y el deseo como una categoría estable, cuando en realidad son el resultado de un proceso de biopoder histórico. Lo que pone en evidencia "Amor propio" a través de la capacidad representacional de sus personajes, es una desmantelamiento de la naturalidad poseída por el cuerpo en relación con el género que el corresponde. Así, es difícil, mas no imposible, imaginar al cuerpo como una sustancia previa a un abigarrado método de posibilidades sígnicas, cuya repercusión consiste en devolver ese mismo cuerpo sin una esencia anterior y sí con una definición ontológica con base en su género, cuya concepción permea, sin lugar a dudas, toda la vida del individuo, tanto en un ámbito temporal como espacial.

Una metonimia de la situación performativa aquí analizada en el cuento es el vestido usado tanto por Roberto como por Anastasia para representar cada uno, a su modo, a Marina Olguín. Este vestido es un leitmotiv a lo largo del texto y lejos de ser un mero dato curioso se convierte en el ser del género: "actué confiada en que mi trabajo la sorprendería y me vi retratada en la marquesina con el vestido rosa que yo había cosido esmerando por copiar con exactitud las lentejuelas doradas de los hombres el encaje de florecitas que subía de la cintura al escote formando una $\mathrm{V}$ la falta muy entallada para lucir las soberbias nalgas que hicieron de Marina un símbolo sexual". ${ }^{283}$ Como se observa, dicha prenda ha definido en gran medida la imagen popular que se tiene de Marina, por esta razón Roberto decide copiar el vestido y usarlo para su show. Casualmente, Anastasia lleva esta misma ropa el día que acude a ver a

\footnotetext{
283 Serna, p. 133.
} 
Roberto al bar, y lo que los personajes asistentes a dicho lugar, así como el lector, tienen ante su mirada es la presencia de dos "mujeres" con la misma ropa: dos Marinas enfrentadas una a la otra. Sin embargo, el vestido, a pesar de ser idéntico no posee la misma tela: el de Roberto es de lino, mientras que el de Anastasia es de algodón. Este guiño no es para nada inocente, se trata de una auténtica declaración de la consistencia performativa del género que más adelante, con el supuesto deseo de intercambiar ropa por parte de Anastasia, será enfatizado. Esto último da la pauta entonces para interpretar la relación sexual de los dos personajes como un suceso netamente alegórico, mediante el cual es posible el intercambio no sólo de vestimenta, sino de rol con base en un desmantelamiento de una identidad fija e impuesta. Finalmente, el intercambio de vestidos planteado por Anastasia ocurre al final del cuento, pero de un modo mucho menos afortunado que el esperado por Roberto:

Después de la tortura caímos en un sueño de plomo. Al día siguiente desperté con ganas de vomita, como siempre que mezclo el alcohol con la marihuana. Desde la cama oí que Marina volvía el estómago pero como estaba demasiado cansada para ir a la grabación tuve que inhalar una raya de coca y fingirme dormida. Salió del baño bastante recuperada y fui a sacar ropa del closet. Entonces encontré a un naco pintarrajeado en mi cama y gritó lárgate de aquí o llamo a la policía pero qué tienes Marina lárgate pendejo. Vi mi peluca en el suelo y entonces deduje recordé el estúpido capricho de la noche anterior que al verme sin el disfraz se había desencantando. En mi desconcierto recogí por error el vestido de algodón y ese mismo día encargué otro a Carlos porque no estoy loca para usar el del mugroso joto que salió del cuarto a medio vestirse, atropellado por esa infame a la que maldije desde el elevado y no la he vuelto a imitar desde entonces. ${ }^{284}$

${ }^{284}$ Serna, pp. 139-140. 
Se observa entonces nuevamente el trastrueque de la perspectiva de un género inamovible. Esto es muy importante para el tema tratado en el presente capítulo, puesto que el objetivo de los tres cuentos planteados para el análisis dentro del mismo sugieren un cuestionamiento de las bases establecidas para el género y la sexualidad, tomando en cuenta una destitución de la posible naturalización del paradigma heteronormativo, pero también una crítica hacia una posible homonormatividad. Con base en esta doble crítica, "Amor propio" plantea una alusión muy clara al tema de las identidades estratégicas tan pormenorizado por la teoría queer. Para comprender esto, debe aclararse en primer lugar la existencia de las identidades fijas, las cuales son el bastimento de un régimen de género bien "definido" e inamovible; sin embargo, no solamente estas representaciones estarían ancladas al espacio de la heterosexualidad, sino también al ámbito de la homosexualidad. Para ambos sistemas de deseo, resulta prácticamente imposible poseer una identidad para enfrentarse a otra, y por esta razón resulta en ocasiones tan problemática la presencia de la bisexualidad. De este modo, cualquiera de los dos sistemas, homo u hetero, poseen como asiento una fijación de la identidad a partir de su carácter único y dominante: o se es una cosa o se es otra. ${ }^{285}$ Buena parte de la teoría queer surgió como respuesta a este axioma, lo cual genera numerosos conflictos al individuo. Para los teóricos queer, la identidad va más allá de cualquier anclaje social y tiene una caracterización plenamente subjetiva y dependiente de los deseos del individuo en cuestión -y la cita de Judtih Butler anotada páginas atrás sobre la

\footnotetext{
${ }^{285}$ Esta situación aplica sobre todo para la creencia de una sexualidad única a lo largo de toda la existencia. Cierto es que para la identidad "homosexual", con frecuencia el individuo atraviesa una etapa de transformación que va de la identidad impuesta a la identidad adquirida con base en los deseos propios, lo cual se traduce como el famoso "salir del clóset". No obstante, cualquiera de las dos etapas definen siempre el carácter y sexualidad del individuo y, claro está, resulta difícil aceptar un cambio o poseer ambas. Esto último concuerda mucho con lo descrito anteriormente sobre "Amor propio" cuando se señala el carácter andrógino que domina el ambiente de la relación sexual entre Roberto y Anastasia.
} 
performatividad justificaría lo mencionado-. Por esta razón, resulta mucho más fácil de concebir una identidad estratégica, la cual cambiaría de acuerdo con la edad, necesidades y contexto del sujeto. En "Amor propio" se observa esta situación al proponer una posible dualidad de identidades y, a la vez, sugerir el matrimonio entre los dos personajes: "íbamos a casarnos porque nada nos lo impedía somos hombre y mujer" ${ }^{286}$ Esta "promesa de matrimonio" lanzada por Anastasia para obtener los favores sexuales de Roberto, resulta fascinante para el espacio queer, pero profundamente repugnante para el ámbito homo y heteronormativo. Lo que pone en tela de juicio la posible unión marital entre los dos personajes es la idea del matrimonio como una situación estable y bien definida en una dicotomía masculino/femenino. Y va más allá todavía al proponer, a modo de sustancia definitoria de una sociedad, la unión entre dos seres marginales y heterodoxos.

En Amores de segunda mano, "Amor propio" no es el único cuento que se ocupa de este problema, puesto que en "El alimento del artista" también se propone y concreta una relación de pareja entre dos seres marginales que mutan de identidad. Los personajes del cuento citado, habitantes al igual de un espacio relacionado con la vida nocturna, realizan una unión muy parecida al matrimonio, pero que sostiene a través de un pacto poco convencional.

Por otro lado, "La gloria de la repetición", perteneciente al mismo volumen de cuentos, presenta una visión un tanto desencantada de una posible homonormatividad, cuando el protagonista del texto acude a un bar gay y descubre casi una copia de la cosmovisión heterosexual se siente "defraudado" y aburrido de advertir en dicho espacio una situación de la que ya está fastidiado.

\footnotetext{
286 Serna, p. 139.
} 
Igualmente, la presencia de personajes que ponen al límite o vulneran el dispositivo de la sexualidad normativa no queda únicamente en Amores de segunda mano. De modo muy amplio, casi toda la obra de Enrique Serna plantea una ruptura con respecto a dichos valores hegemónicos y, obviamente, una crítica hacia el posible daño causado por los mismos en sujetos con una sexualidad y deseo diferente. Un caso muy particular al respecto es el cuento "La tía Nela" incluido en El orgasmógrafo. En dicho texto el personaje principal, Efrén, también experimenta un "cambio" de identidad que va desde una posible masculinidad/heterosexual hasta una transexualidad/femenina. Todo esto se corresponde a su vez con el discurso contestatario de su tía, Nela, quien representa la perspectiva hermética tenida por la sociedad mexicana con respecto a las identidades disidentes de la "matriz heterosexual": De este modo, entre los dos personajes se construye un suerte de estira y afloja con base en el enfoque que cada uno de ellos posee del cuerpo: mientras para Efrén se trata de algo sujeto a modificaciones por motivos placenteros, para la tía es algo imposible de “alterar" por el sustrato religioso de su cosmovisión.

Con estos ejemplos, es fácil advertir cómo la obra de Serna presenta un nuevo ángulo del género y la sexualidad mexicanas usando a personajes cuya representación resulta poco adecuada para dichos fines hegemónicos e inamovibles. Así, de vuelta a "Amor propio", el lector puede percatarse de varias infracciones lanzadas contra el dispositivo del poder que convierte a los cuerpos de sustancia "pura" a un sujeto al servicio de un ámbito social, cuya característica es la capacidad de definir roles sin "preguntar" al individuo si desea llevarlos a cabo. Desde la visión de una identidad estratégica, la crítica hacia la imposición de un determinado género, una sexualidad multiforme y heterodoxa, así como la alegoría del plano simbólico del poder establecido sobre las diferentes corporalidades, "Amor propio" condensa un agudo cuestionamiento de la heterosexualidad y el patriarcado; sin embargo, va más allá 
de estas características y también supone una crítica a la homonormatividad, cuya hegemonía planteó también un socavamiento de las identidades marginales de la misma, como el travesti, la prostituta, el bisexual, el sadomasoquista, entre otros. De forma general entonces, el cuento aglutina, en pocas páginas, un acérrimo debate en contra de todas aquellas representaciones que oprimen al sujeto y supone un coqueteo con el universo queer.

Ahora bien, el texto que cierra este repaso por la cuentística mexicana con un trasfondo queer es “¿Te gusta el látex, cielo?”, incluido en el volumen homónimo, publicado por Nadia Villafuerte en 2008. Este cuento se ha elegido para figurar en este apartado por diversas cuestiones, entre las cuales no sólo se encuentra el hecho de apuntar hacia un profundo cuestionamiento de las divisiones genéricas y sexuales, sino por descubrir el mundo de la frontera sur, la migración en dicho espacio y un ácido debate sobre la sociedad mexicana de la década pasada. Por todas estas razones, el texto de Villafuerte no puede leerse como una narrativa inocente; al contrario, se trata de un cuento complejo, vasto y con diversos guiños que van desde el ámbito particular -el "ser mexicano"- hasta un plano más universal - los anhelos y recovecos del hombre.

En el ámbito estructural, puede afirmarse que “¿Te gusta el látex, cielo?” presenta una narrativa fragmentaria, la cual está integrada por diversos cronotopos y rupturas temporales en el ámbito discursivo. De frente a esta situación que necesita hasta cierto punto una postura activa por parte del lector, el narrador es heterodiégético y bastante claro con respecto a los hechos mostrados; además, hace uso de un estilo directo que convierte, con frecuencia, el plano discursivo en una verdadera polifonía narrativa con el objetivo de brindar información de "fuentes directas", es decir la propia voz y perspectiva de cada uno de los personajes involucrados en los sucesos relatados. 
Integrado por dieciocho fragmentos de extensión variada, el cuento de Nadia Villafuerte posee una dimensión bastante grande con respecto al resto de los textos que integran el volumen. A lo largo de sus casi cincuenta páginas, el lector acude a una frontera sur con características verídicas y aterradoras; pero no sólo se detiene en una descripción espacial y temporal del escenario habitado por los personajes, sino que altera la perspectiva clásica del cuento de iniciación para proponer una configuración desencantada, destructiva y dolorosa del proceso de aprendizaje. En diversos cuentos analizados con anterioridad, se habló un poco al respecto de este tema y, con frecuencia, los personajes de los textos con la característica del buldingsroman presentaban, en general, un deseo de ruptura con su entorno para adentrarse en un panorama con mayor libertad y, claro está, felicidad. El reiterado comming out o "salir del clóset" se convertía en el fundamento de dicho transcurso llevado a cabo por el personaje, lo cual lo conducía a un ámbito de exploración y consolidación de su propia sexualidad. En el caso de “¿Te gusta el látex, cielo?”, el tópico de la iniciación no se vincula con dichos resultados, el proceso del aprendizaje que podría ser benéfico concluye en un sitio desolador. El personaje que llevaría a cabo esta transformación en el cuento es Elena, quien pasa de ser una niña caprichosa, pero absolutamente soñadora, a una mujer ambiciosa y traicionera, cuya postura es destruir todo aquello que pueda obstruir sus deseos, aun a quienes, de cierto modo, la han apoyado. Incluso este cambio se manifiesta mediante la alteración de su nombre por parte de Glenda, el travesti que la compra en Honduras para prostituirla en Chiapas, quien decide agregarle una hache al inicio de la palabra que la denomina para darle cierto "aire" de sofisticación: de esta suerte, Elena se transforma en Helena.

El tema de la ruptura con respecto a una articulación canónica del cuento de iniciación está en concordancia con el hecho de la posmodernidad en la literatura ya mencionado en el 
caso de los dos cuentos analizados con anterioridad. Sin duda, el poner en tela de juicio los modos de narrar y el tema de la diégesis, transgredir las verdades absolutas y proponer nuevas formas de concebir la literatura son elementos característicos de de este tópico. En el caso del cuento, el aprendizaje "a la inversa" enfatiza estas posibilidades: el personaje no se instruye para realizar algo constructivo, que sería la meta esperada de este intervalo, sino para enfrentarse a un ambiente hostil que lo lleva, junto con su propia capacidad de ser, a la autodestrucción.

Otros aspectos emparentados con el tema de la posmodernidad en el ámbito literario serían indudablemente los contextos de la frontera y la migración aparecidos dentro del cuento aquí estudiado. Muy relacionados entre sí, estos dos aspectos temáticos han permeado a la creación literaria mexicana desde hace ya varias décadas. No hay duda de que todos los países que comparten una frontera o, de algún modo, aquellos individuos que transitan de una nación a otra -sea cual fuere el fin de dicho movimiento-, atraviesan un complejo camino, cuya definición bien puede ser brindada por la múltiple acepción significativa del verbo "extrañar" proporcionada por el Diccionario de la Real Academia de la Lengua Española: “1. Desterrar a país extranjero. / 2. Ver u oír con admiración o extrañeza algo. / 3. Sentir la novedad de algo que usamos, echando de menos lo que nos es habitual. / 4. Echar de menos a alguien o a algo, sentir su falta. /5. Afear, reprender. / 6. Apartar, privar a alguien del trato y comunicación que se tenía con él. / 7. Rehuir, esquivar. / 8. Rehusarse, negarse a hacer una cosa". Sobre todo los puntos 1, 2, 3, 4 y 6, son los más cercanos al tema de la frontera y la migración, puesto que este movimiento implica siempre la alteración del estado habitual y el paso a otro que resulta poco familiar. De este modo, la dualidad que puede presentar el término de la frontera, se observa directamente relacionada con el mismo binomio de los cronotopos proporcionados por el carácter de la migración. 
$\mathrm{Al}$ respecto, el cuento de Villafuerte presenta esta dualidad, sin embargo, el auge de la literatura de frontera y los estudios sobre la misma en México han aludido, de modo masivo, al espacio del norte, mientras que el sur ha sido poco estudiado desde esta perspectiva. El acierto entonces de la autora consiste en darle voz y privilegio a este sitio que poco ha sido abordado tanto desde el ámbito creativo como desde el académico. Así, “¿Te gusta el látex, cielo?" es un texto poseedor de numerosas "claves" para comprender el ámbito de la frontera sur, sobre todo en lo que se refiere a su complejidad y problemática.

Ana María Hernando menciona en "El tercer espacio: cruce de culturas en la literatura de fronteras" que existen numerosos términos con los cuales se puede definir el concepto aquí anotado. Destacan entre todos ellos la idea de la fisión y la fusión, el papel de la interpretación, la perspectiva de un poder central y uno periférico, las propiedades de hibridez y diferencia, así como las relaciones establecidas entre el "yo" y lo "otro". Con base en esta circunstancia y, por supuesto, en la situación de poderío económico, es fácil advertir la preeminencia del discurso de la frontera norte en la literatura mexicana. Igualmente, las marcas de hibridez y diferencias en cuanto a las identidades y al lenguaje resulta más probable encontrarlas entre el amplio espacio de límite territorial compartido entre México y los Estados Unidos. No obstante, Nadia Villafuerte pone el tema sobre la mesa al narrar y problematizar sobre una frontera poco revisada en correspondencia con un centro y una periferia ya reiteradas. En este caso, el mirar hacia la frontera sur mexicana a través de la narrativa de esta autora se convierte en un hecho profundamente revelador para el lector que no habita dicho espacio.

En “¿Te gusta el látex, cielo?” saltan a la vista como características intrínsecas del espacio de la frontera sur la miseria, el abandono, la impunidad, la despersonalización, la ruptura con respecto a valores tradicionales y, en relación con el tópico estudiado a lo largo 
de este trabajo, el cuerpo como espacio de cruces simbólicos y de deseos. De este modo, el cuento posee personajes que habitan uno u otro lado, aunque, en ocasiones, las diferencias entre ellos son mínimas y se reducen a una cuestión de "documentos". ${ }^{287}$ Como se dijo anteriormente, los dos personajes principales del texto son Helena y Glenda, seres representantes del sur de México y de Honduras, respectivamente. Si bien es obvio que estos dos países no comparten una línea fronteriza entre sí, en el texto prevalece la idea del intercambio y de cruce entre ambos. Glenda acude con cotidianeidad a los países centroamericanos con el fin de "comprar" jovencitas y prostituirlas posteriormente en su bar. En la plática tenida entre la madre de Helena y Glenda, al principio del texto, se percibe esta situación de la dualidad geográfica y el trato de blancas: mientras el comprador alude a la posibilidad de cambio de vida de la chica una vez que llegue a su "restaurante" para el cual la necesita, la madre determina que todas esas ventajas no son tales y, en realidad, su hija terminará siendo una sexoservidora al igual que en su tierra natal. A partir de este momento, la prostitución se convierte en un tema protagónico del cuento y aparece como coyuntura indisoluble del ámbito fronterizo. Así, el cuento manifiesta, mediante la presencia de un solo personaje, la vida de miles de jovencitas que, por voluntad propia o sin ella, trabajan como meretrices en dicho espacio. Y es en este punto donde resalta el tema de la migración, puesto que Helena es un sujeto que ha dejado a un lado el espacio geográfico familiar para ubicarse en uno desconocido, pero con ciertas posibilidades de prosperidad; de forma general, la situación del migrante está relacionada con el dolor, es decir con la pérdida del horizonte

\footnotetext{
${ }^{287}$ El hecho de la documentación es algo muy reiterado en el texto. Con frecuencia, el narrador se refiere a la falsedad de los papeles de "identidad" de Helena, sobre todo en el tránsito de la huída: "No todos los ilegales de la frontera sabían dónde comprar buenas réplicas de identificaciones oficiales. La suya era una buena. En la ventanilla entregaron su boleto". Nadia Villafierte, “¿Te gusta el látex, cielo?”, en ;Te gusta el látex, cielo? (México: Fondo Editorial Tierra Adentro, 2008), p. 143.
} 
propio para atravesar uno diferente; sin embargo, en el caso de este personaje el posible dolor ante dicha pérdida es mínimo, y podría decirse que hasta nulo. En primer lugar, cuando Glenda acude a la casa de Helena para comprarla, es esta última quien decide salir de casa para encontrar un futuro más favorecedor. Así, lejos de parecerle el abandono de su madre y hermanos un hecho aterrador debido a su corta edad, en realidad le resulta satisfactorio. Más adelante, cuando Helena y Glenda deben huir, el trayecto en autobús le genera a la primera cierta "nostalgia efímera", en la cual recuerda su niñez en la casa familiar, pero este hecho hasta le parece algo "estúpido", y lo único que puede asimilar es una vida bastante difícil al lado de una madre abandonada por su padre desde el momento en el cual supo del embarazo, una madre que posteriormente tiene una vida sexual activa con otros sujetos, lo cual, según el narrador, influye en la protagonista para determinar ese carácter relacionado con el erotismo y la prostitución. Es preciso mencionar aquí los deseos de Helena con respecto a su futuro que tenía cuando era todavía una niña:

Eso de soñar era más bien suponer también escenas: el príncipe de Helena no llegaría en auto sino tal vez en una camioneta americana, estaría por ahí en lo que ella bebía con otras princesas desempleadas; el príncipe sería algún narco llevándole cocaína, seguro, se decía. Y seguro que un día se vería en esas calles del Norte, manejando una camioneta del año, paseándose por las avenidas llenas de bares, hoteles y farmacias, entrando a los malls a comprarse ropa. Anhelaba estas imágenes para sí: en el fondo, era igual que los demás, una estúpida arribista. ${ }^{288}$

Como puede observarse, hay una doble visión del aspecto migratorio: 1) el relacionado con el abandono de su tierra natal para ir al sur de México, con el objetivo de mejorar su situación

288 Villafuerte, p. 138. 
económica, y 2) un posible traslado al norte del mismo país, cerca o, incluso, en territorio estadounidense. Esta última posibilidad, aparte de estar expresada en el fragmento anotado, emerge también como oferta cuando Antero Rojas le propone a Helena asesinar a Julio Nazar: "Te propongo papeles legales de por vida, que involucremos al travesti de tu jefe, y que te largues a Tijuana, muy lejos de aquí. Allá tengo un amigo de bienes raíces que nos facilitará todo. Lo demás, si quieres cruzar, los decides tú. Pero al menos, por si no lo sabes, Tijuana sí es una ciudad enorme". Por tanto, el aspecto migratorio del personaje aparece de modo recurrente y, además, afecta verdaderamente las diversas posibilidades de vida del mismo.

El espacio fronterizo y la migración provocada por las aspiraciones a un mejor nivel de vida tienden una relación simbólica en el texto de Villafuerte con las características sexo/genéricas de sus personajes. Y es en este aspecto en el cual el cuento produce un interés relevante para el avistamiento del universo queer en la literatura mexicana. Tal como se dijo al principio de este apartado, “¿Te gusta el látex, cielo?” propone, al igual que los dos cuentos analizados ya, una visión alternativa de la heteronormatividad y la homonormatividad. Sería bueno recordar aquí lo dicho por David William Foster al respecto de la teoría queer:

Son los las características descollantes de lo queer en lo que se refiere a llevarlo hacia una teorización cultural:

1- Lo queer se fundamenta en una epistemología abierta que repudia las definiciones fijas sobre las que se tensa el patriarcado y sus definiciones de la sexualidad. [...]

2- En vista de que el patriarcado propone un sistema cerrado de análisis social e histórico, tanto en lo que respecta a lo que excluye como en lo referente a sus aspiraciones hacia un modelo que lo engloba 
y lo explica todo, lo queer se sustrae de la urgencia de formular un modelo igualmente excluyente y englobante. ${ }^{289}$

Puede decirse que, de modo general, el cuento de Villafuerte está relacionado con los dos puntos citados. En primer término, es posible advertir en los personajes una sexualidad marginal -y, claro está, periférica- cuyo poder de cuestionamiento está centrado en una crítica hacia la heteronormatividad. Tanto Glenda como Helenda articulan un discurso sexual y de identidad poco ortodoxo en cuanto a fijaciones de índole sexual y de género se refiere. A su vez, en este punto puede concebirse una profunda alegoría de la destrucción del patriarcado, observada sobre todo en la muerte Julio Nazar, provocada por los dos personajes mediante una brutal golpiza. Esta cuestión será explicada más adelante con detenimiento. En el segundo inciso anotado por Foster, es convincente una demostración de no "ajustamiento" tampoco a una identidad excluida de forma fija. El personaje que llevaría a buen término este supuesto sería Glenda, quien permanece en un estado de ambigüedad con respecto a una identidad: si bien el personaje es un travesti y tiene un deseo homoerótico, no permanece herméticamente en dicho estado, su representación es estratégica y su deseo es más bien bisexual; por tanto aglutinaría una serie de características que no corresponden necesariamente con una visión "correcta" de la homosexualidad y el travestimiento, según la cosmovisión mexicana tenida sobre la sexualidad hegemónica y sus disidentes. Al respecto de eso, Javier Sáenz señala que la crisis en el ámbito del movimiento de liberación de la disidencia sexual, productora de la emergencia de la teoría queer, fue favorecida por los efectos de la pandemia del sida, el anquilosamiento del feminismo hacia la década de los

\footnotetext{
289 David William Foster, Producción cultural e identidades homoeróticas. Teoría y aplicaciones (Costa Rica: Editorial de la Universidad de Costa Rica, 2000), pp. 19-20.
} 
ochenta y el hermetismo de la lucha gay hacia otras identidades imaginadas como más abyectas y nocivas: "Esta política de integración [con el discurso de la heterosexualidad] va a tener como corolario la aparición de un discurso conservador cada vez más centrado en la 'respetabilidad gay', a costa de criticar aquellas conductas sexuales y políticas que se alejan del criterio de normalidad". ${ }^{290}$ Glenda responde entonces a esta visión alejada de los criterios de "ajustamiento" de un discurso homoerótico a la "matriz heterosexual", puesto que su representación no está delimitada por este halo de conservadurismo dentro de la misma disidencia.

Frontera, migración y ruptura de la normatividad sexo/genérica son, entonces, las tres directrices sobre las cuales está fincada la diegésis de “¿Te gusta el látex, cielo?”. Pero habrá que ir con mayor detenimiento para analizar el tercer eje y su relación con el cuestionamiento del dispositivo del poder y su capacidad de "materializar" cuerpos. Glenda es un personaje muy complejo al respecto de esta circunstancia, ya que desde el principio del texto se demuestra cierta "pasión" por Elena, a quien decide comprar no sólo por las posibilidades y ganancias económicas que podría ofrecerle al prostituirla en su bar, sino también por cierto deseo experimentado al ver a la jovencita en su ciudad natal: "Glenda salió sintiendo un ligero escozor en la verga calzada dentro de sus bragas". ${ }^{291}$ De este modo, el personaje que en un inicio se presentaba como una mujer y, de quien más adelante se descubre su carácter de travesti, participa de un deseo no imaginado para su representación de identidad.

Esta circunstancia puede ser inscrita dentro de lo dicho por Sáenz sobre el contexto de emergencia de la teoría queer, puesto que es poco plausible una identidad vulneradora de

\footnotetext{
${ }^{290}$ Javier Sáez, "El contexto sociopolítico de surgimiento de la teoría queer. De la crisis del sida a Foucault", en David Córdoba et al, Teoría queer, p. 72.

${ }^{291}$ Villafuerte, p. 103.
} 
los principios normativos planteados desde el régimen de la sexualidad hetero y la posible hegemonía homo. Glenda lleva a cabo una consigna en la cual el cuerpo se transforma en un ámbito de libertad y no de constreñimiento, muy cercano a lo señalado por Foucault: "Entonces la sexualidad es cuidadosamente encerrada. Se muda. La familia conyugal la confisca. Y la absorbe por entero en la seriedad de la función reproductora. En toro al sexo, silencio. Dicta la ley la pareja legítima y procreadora. Se impone como modelo, hace valer la norma, detenta la verdad, retiene el derecho de hablar -reservándose el principio del secreto". ${ }^{292}$ Con base en esto, se sobreentiende que la dicotomía masculino/femenino, colocada encima de las diferencias biológicas del varón y de la hembra, surgida de esta necesidad reproductiva de la familia, va a concretar una concepción binaria del género. Así, es factible relacionar esto con lo mencionado por Sáenz, quien acota las posibilidades conservadoras del propio discurso de liberación gay: la emulación de los moldes de la "matriz heterosexual" en el seno de otra matriz que se ofrecía como cortadora de cadenas anquilosadas y llevó su afán de inclusión a planos de hegemonía. El personaje de Glenda corta pues con las dos hegemonías creadas desde estos dos ámbitos, y esto se advierte con claridad en la cita ya mostrada sobre el personaje en la cual su falo en excitación se encuentra acomodado al interior de unas bragas, ropa considerada para el uso exclusivo de las mujeres por antonomasia. Páginas más adelante, esta "problemática" de una representación travesti enfrentada con un deseo heterosexual se hace patente: "Sus enormes pestañas postizas, su sonrisa grotesca, flotaban en el marco del espejo. El deseo para él/ella, a veces, carecía de nombre. El deseo para Glenda era una piel joven, la de su díler, la de una Helena rotunda a sus diecisiete años. El deseo era el deseo por ocupar, sitiar cualquier cuerpo. Sin pensarlo,

\footnotetext{
${ }^{292}$ Michel Foucault, Historia de la sexualidad v. 1, p. 9.
} 
sin confirmar nada, desear a un hombre o a una mujer empezaba a darle lo mismo". ${ }^{293}$ Como lo confirma esta cita, Glenda crea para sí un espacio amorfo, en el cual tiene cabida cualquier necesidad erótica sin necesidad de generar una identificación o un molde para definirla. El cuerpo y sus necesidades, nuevamente, son una punta de lanza contra cualquier ataque normativo venido del exterior.

Un concepto creado por Foucault y puesto muy en boga también por la teoría queer es la unidad del dispositivo y el poder establecido por éste sobre el hombre:

El poder sobre el sexo se ejercería de la misma manera en todos los niveles. De arriba abajo, en sus decisiones globales como en sus intervenciones capilares, cualesquiera que sean los aparatos o las instituciones en las que se apoye, según los engranajes simples e indefinidamente reproducidos de la ley, la prohibición y la censura: del Estado a la familia, del príncipe al padre, del tribunal a la trivialidad de los castigos cotidianos, de las instancias de la dominación social a las estructuras constitutivas del sujeto mismo, se hallaría, en diferente escala, una forma general de poder. Esta forma es el derecho, con el juego de lícito y lo ilícito, de la transgresión y el castigo. Ya se le parece la forma del príncipe que formula el derecho, del padre que prohíbe, del censor que hace callar o del maestro que enseña la ley, de todos modos se esquematiza el poder en una forma jurídica y se definen sus efectos como obediencia. Frente a un poder que es ley, el sujeto constituido como sujeto -que está “sujeto"- es el que obedece. ${ }^{294}$

Las marcas determinantes del "sexo" son protegidas entonces por todos los personajes integrantes de una determinada sociedad, incluso de los mismos que se encuentra oprimidos. La "obediencia" de todos y cada uno de los individuos, convertidos ya en "sujetos", implica una garantía de la ley creada. En el cuento, este acontecimiento queda muy claro por las constantes alusiones del resto de los personajes hacia Glenda, entre ellos la misma Helena.

\footnotetext{
293 Villafuerte, p. 107.

${ }^{294}$ Foucault, p. 103.
} 
Un ejemplo de ello son el resto de las prostitutas que trabajan en el "Bombay", quienes cuestionan con frecuencia el hacer de Glenda:"-Helena, Helena, ¡bah! Pinche mocosa sudaca — decían las otras putas, con hastío y envidia. — ¿Qué sabes tú de ella? Es marica por eso no se coge a ninguna. Contigo está entusiasmada, eso ahora. Al rato de va a echar". ${ }^{295}$ Aquí se enfatiza el hecho de la custodia y censura establecida por el resto de la sociedad sobre los diversos "cuerpos" creados por el dispositivo del poder: nadie puede escapar a un escrutinio de su identidad y, por supuesto, es inadmisible la idea de una ruptura de ciertas linealidades correspondientes con una visión fija de la sexualidad. Si Glenda es un travesti, por ende los demás personajes le adjudican un homoerotismo dependiente de esta representación. Para ellos resultaría casi imposible que el personaje travestido adquiera un deseo cuyo contenido lo coloque extrañamente en un ámbito cercano a la heterosexualidad. El traslado de la dualidad e inamovilidad de la "matriz heterosexual" se lleva al ámbito de la disidencia: en la cotidianeidad no hay forma de sortear las barreras de una dicotomía firme y arraigada en la mentalidad de los individuos acérrimamente.

Al igual que la mayoría de los personajes estudiados en el presente trabajo, Glenda señala el inicio de su actividad homoerótica y plantea el ya reiterado "salir del clóset" a partir del descubrimiento placentero de su sexualidad: "Una noche, seducido por el primo con quien tuvo su primera experiencia, Genaro se vistió de mujer. Le gustó". ${ }^{296}$ Rotundamente, el hecho de la homosexualidad y el travestimiento van de la mano en el imaginario colectivo, adquirido incluso por los propios personajes involucrados. Esta asimilación de la "norma" provoca sendos y complejos problemas para estos sujetos. Butler al respecto menciona: "La idea de que el sujeto está apasionadamente apegado a su propia subordinación ha sido

\footnotetext{
295 Villafuerte, p. 107.

${ }^{296}$ Idem, p. 111.
} 
invocada cínicamente por quienes intenta desacreditar las reivindicaciones de los subordinados", ${ }^{297}$ y más adelante agrega: “yo argumentaría que el apego al sometimiento es producto de los manejos del poder, y que el funcionamiento del poder se transparenta parcialmente en este efecto psíquico, el cual constituye una de sus producciones más insidiosas" ${ }^{298}$ En algunas ocasiones, Glenda manifiesta esta idea de rechazo hacia la posible ambigüedad generada por su cuerpo, representación y deseo: “Quizá le confundía no saber, no saber nada, dejarse llevar, como si fuese indistinto ser hombre o mujer, como si fuese sencillo llevar las dos partes atadas" ${ }^{299}$ No obstante, es sobre todo en los otros en quienes se aparece esta coyuntura, ya que el personaje asume, en la mayoría de las ocasiones, sin mayores dificultades la "extraña” mezcla de identidad y deseo establecida por sí misma.

El deseo tenido hacia la hondureña, como llama el narrador a Helena, por parte de Glenda se traduce en constantes encuentros sexuales, en los cuales los dos personajes resultan reconfortados. Además, este aspecto no se reduce solamente a una situación carnal entre Glenda y Helena, ya que la primera disfruta en numerosas ocasiones verla prostituyéndose con otros individuos, lo cual se conecta con lo dicho también por Sáenz: "prácticas como el sadomasoquismo, el travestismo, la pluma, el sexo en público, el fetichismo, el sexo con adolescentes, la promiscuidad, etc., se van a ver criticadas incluso por el mismo discurso oficial de los gays más integrados en el sistema". ${ }^{300}$ El universo queer aparece en el cuento entonces a través de una demostración de todas aquellas conductas sexuales más repudiadas por las dos normatividades, hetero y homo. Así, al igual que en "Amor propio" y "El alimento del artista" de Enrique Serna, el lector descubre una sexualidad exacerbada y poco

\footnotetext{
${ }^{297}$ Butler, Mecanismos psíquicos del poder, p. 17.

298 Loc. cit.

${ }^{299}$ Villafuerte, p. 111.

${ }^{300}$ Sáenz, p. 72.
} 
convencional: el furtivo y apasionado contacto entre un travesti, regateador de mujeres, y una prostituta que se asimila, sin menoscabo de su persona, como tal.

La presencia de la prostitución en el cuento redunda más en el planteamiento de una perspectiva queer. Por parte de Helena este trabajo es visto sin mayores complicaciones: el personaje sugiere en él un medio para alcanzar provecho económico y, en ocasiones, satisfacciones sexuales. Igualmente, Glenda, siguiendo la línea del cuento de iniciación, se convierte en una suerte de maestro de un aprendizaje "a la inversa", en el cual la jovencita hondureña aprende a ser una sexoservidora y obtener buenos recursos de este empleo. Este incidente recuerda a la ya citada novela de Zapata, El vampiro de la colonia Roma, en la cual el protagonista, Adonis García, es un prostituto que lleva a buen término su trabajo sin preocupaciones morales. De este modo, el gesto de una posible reivindicación de la prostitución en “¿Te gusta el látex, cielo?” es también una afirmación de la "pólvora” queer. Ocurre una deconstrucción de todos aquellos artilugios -que Butler denominaría como los mecanismos psíquicos del poder- con el objetivo de plantear una salida alternativa a la prostitución desde un espacio satisfactorio y no peyorativo. Así, Helena y Adonis estarían hermanados por esta postura tan recalcitrante para el dispositivo del poder: afirmarse en una sexualidad e identidad "abyecta" implica, a su vez, destruir los procesos mediante los cuales ésta adquiere su carácter periférico, transformándola en un sitio de "centro" y sin posibilidades de ser denostado.

El personaje de Helena carga con múltiples interpretaciones en el plano simbólico, ya que, aparte de llevar a cabo su trabajo como prostituta en un ámbito fronterizo, periférico y marginado, representa un ser con fuertes ambiciones que, en buena medida, resultan inocentes. Con esto no se quiere decir que Helena sea una chica sin conocimiento de causa, sino que ignora más bien el sitio a donde podrían llevarla todos aquellos sucesos para obtener 
un beneficio. Cuando Antero Rojas le propone el "negocio" de asesinar a Julio Nazar a cambio de documentos y migración al norte, no duda en traicionar a la misma Glenda. Igualmente, en cierto modo, encarna la posición de los indocumentados centroamericanos que llegan al país en busca de oportunidades o atravesarlo con el objetivo de llegar a los Estados Unidos. La explotación, discriminación y maltrato sufrido por dichos individuos se traduce en el cuento en una suerte de juego a la inversa con respecto a la literatura fronteriza del norte. Con frecuencia, en estas narrativas mencionadas y en el imaginario colectivo, el estadounidense es observado como el villano con sofisticados mecanismos de maltrato hacia los mexicanos que cruzan la línea en busca de un futuro promisorio. En el caso de “¿Te gusta el látex, cielo?" el acontecimiento es a la inversa: el explotador es un político mexicano ambicioso, quien ocupa a Helena para cumplir sus deseos y aniquilar al enemigo que lo ha mantenido en un segundo plano. Además, como se lee al final del cuento, lejos de recibir una buena recompensa por el hecho, la jovencita hondureña sólo es asesinada, mientras Glenda termina en la cárcel debido a la traición realizada por la primera.

El espacio de la política se convierte así en otro de los ámbitos criticados de forma directa por el texto. El cuento pone sobre la mesa prácticas ya conocidas por la sociedad mexicana, como lo serían la corrupción, la impunidad, el arrebato del poder y la traición. Rojas y Nazar son los personajes que personifican esta articulación, el primero, como ya se anotó, con un deseo de obtener el poder a cualquier costo y, el segundo, un tanto más benevolente con respecto a lo que podría pensarse del "actuar" del sujeto involucrado en la política, aunque en su vida privada, especialmente en el matrimonio, hay un fracaso y negación muy claras.

Indudablemente, la crítica lanzada sobre el enlace conyugal entre Nazar y Estrella está centrada también una posición cercana al ámbito queer. Se trata entonces de desarticular 
todas aquellas ataduras implantadas por el dispositivo del poder. De este modo, el matrimonio se convierte en un lugar obligado de los individuos, y todo aquel que no lo lleva a cabo queda en un ámbito de desprestigio, como lo serían el caso del "soleterón" y la "solterona", tan sometidos a la burla por parte de la sociedad mexicana. En cambio, en el texto de Villafuerte se muestra una visión desencantada del mismo, ya que entre Nazar y Estrella existe una relación fría, distante, monótona y hasta infeliz:

Apenas ayer había visto a su marido en el desayuno, o mejor dicho, desayunó con él sin verlo, con prisa, como todos los días. Y era increíble la manera en que el tiempo se encargaba de borrar las cosas. [...] Si, Estrella sabía que su marido visitaba burdeles, como todos los hombres que en determinado momento necesitan demostrar precisamente ahí el hecho de que el matrimonio y la vida cotidiana son indisolubles. Pensó en los cinco años de matrimonio, en los "Señor, Jefe, Licenciado" que repetía su esposo con frecuencia, como si se tratara de una jerarquía militar, títulos que en realidad eran lamidas de botas. Pensó en las gatas secretarias que seguramente él se cogía de vez en cuando; y pensó también en la muerte, en identificar el cadáver, en verle la cara por última vez y preguntarse si en realidad lo quería. En su muerte, definitivo: también en la cuenta bancaria, la casa, las propiedades, la ciudad violenta de que saldría con motivos suficientes hacia cualquier lado. [...] Definitivo: ambos se habían cansado, a pesar de no saber determinar en qué consistía exactamente ese cansancio. El tiempo había realizado su ineludible tarea. ${ }^{301}$

Aparte de esta mirada dolorosa y desventurada sobre el concepto de la unión conyugal heterosexual, en el cuento hay dos elementos que igualmente desacralizan la hegemonía patriarcal, las identidades fijas y todo aquello emanado de las mismas. Si la evidencia de la relación fracasada entre Estrella y Nazar está nombrada en un tono directo, estos dos sucesos

\footnotetext{
301 Villafuerte, p. 120.
} 
están colocados en un estilo más cercano a lo alegórico. El primero trata sobre la forma en la cual muere Nazar. Debe recordarse aquí que Helena engaña y convence a Glenda de "golpear" a Nazar en vista de la afrenta hecha por este último hacia la primera. Este último hecho, como queda bien claro en el texto, fue un artilugio inventado por Helena con el objetivo de conmover a Glenda y provocar en el mismo personaje un deseo de venganza, dado que la jovencita hondureña da por sentados la pasión y amor tenidas por el travesti hacia ella. La afrenta, por tanto, consiste en un navajazo dado a propósito por Rojas en el rostro de Helena, con esto Glenda acepta el trato y se une a la supuesta pretensión de venganza iniciada por la primera. Posteriormente, ambos personajes se las ingenian para conducir a Nazar cerca de la playa y propinarle una golpiza tremenda que lo llevará a la muerte. De modo literal, este acontecimiento no es más que una parte más de la diégesis; sin embargo, en el acento alegórico ya señalado, y acercándolo más al cuestionamiento realizado sobre las normatividades genéricas, se trata de una suerte de destrucción simbólica del patriarcado: ${ }^{302}$ dos personajes marginales flagelan el cuerpo de un "hombre" poderoso y dominante: "Glen y Helena seguían pegándole, había en ellas una rabia hermosa, una violencia a punto de regarse como la espuma sobre la playa. Glen no se lo pensó dos veces si veía a Helena actuar así; estaban embriagadas de rabia golpeando una, diez, muchísimas veces, llenas de placer por ver al hombre desvanecerse". 303

El segundo elemento de estos elementos alegóricos del texto radica en el título mismo y en otra parte de la diégesis. Una vez en su huída, Glenda y Helena llegan a Mazatlán, donde la primera tiene un par de amigos, travestis también, quienes las invitan a un concurso de

\footnotetext{
302 Sobre esto, Foster menciona: "Lo queer busca la liberación de la imposición patriarcal y su circunscripción del placer o de su exclusión más allá de circunstancias muy parciales". Producción cultural e identidades homoeróticas, p. 54.

303 Villafuerte, p. 126.
} 
belleza gay. Para dicho evento, a Glenda le es ofrecido por parte de Shirley, una drag muy conocida por este personaje, el papel de jurado, debido a su calidad de travesti con trayectoria y, claro está, conocedor del ambiente. Al hacerlo, le comenta lo siguiente: “Te pondré como jurado, Glenda. ¿Te sigue gustando el látex? Vas a probarlo ahora. ¡Mmm, ese olor! ¡La sensación de estar aprisionada!" ${ }^{304}$ El látex en este caso se refiere al material con el cual se confeccionan algunos corsés, esto con la meta de "moldear" el cuerpo de los individuos y adquirir algunas "curvas" más pronunciadas que acentúan su feminidad. No obstante, la cuestión no queda ahí -y tampoco es gratuito por el hecho de que en dicho diálogo está anotado el título del cuento-, el suceso puede ser llevado a un ámbito donde simbolice el poderoso revestimiento emanado de las identidades. Este vericueto alegórico del texto de Villafuerte está muy cercano al leitmotiv del vestido en "Amor propio" de Enrique Serna: ambos objetos aluden a la posibilidad para "transmutar" de identidad y, obviamente, desmantela la idea de las identidades fijas. Por otro lado, hay cierta inflexión en el diálogo citado que bien puede imprimir cierto toque sadomasoquista. Cuando Shirley menciona la eventualidad de estar "aprisionada", y además que dicho hecho produce placer, alude a un regodeo en el dolor y la sumisión. La teoría queer al respecto se pronuncia favorable, dado que tanto el discurso homonormativo como la hegemonía feminista plantearon la idea de un sujeto supuestamente desvinculado del hecho subordinado, es decir que se buscaba construir un individuo detentador de una capacidad de poder. Sin embargo, el surgimiento de lo queer plantea algo diferente: no se puede excluir a quienes, de buen modo y por motivos relacionados con el placer, aceptan un papel "subordinado", siempre y cuando conozcan las diversas posibilidades que podrían permitirles el "empoderamiento". Así, el

\footnotetext{
304 Villafuerte, p. 141.
} 
sadomasoquismo entró por una puerta muy amplia a los estudios queer, justamente por el hecho de pronunciarse en favor de la libre elección del rol en el acto sexual. Cabe mencionar aquí que, en una de las novelas más influyente de la literatura homoerótica latinoamericana, El beso de la mujer araña de Puig, hay un pronunciamiento por el asumirse en un rol "pasivo" sin menoscabo de la persona: “¿Y qué tiene de malo ser blando como una mujer?, ¿por qué un hombre o lo que sea, un perro, o un puto, no puede ser sensible si se le antoja?"”305 
Conclusiones

Los diferentes cuentos estudiados en este trabajo permiten advertir cómo se ha ido creando el espacio para la manifestación del homoerotismo no sólo en el ámbito de la cuentística, sino, en general, en el de la literatura mexicana. Desde "Manolito el pisaverde", de Ignacio Rodríguez Galván, hasta “¿Te gusta el látex, cielo?”, de Nadia Villafuerte, se ha configurado un universo cargado de referencias al dispositivo de la sexualidad establecido en el seno de la cultura del país, pero, a la vez, estos textos manifiestan la forma en la cual la propia literatura ha abierto un espacio de diálogo con respecto a la moralidad mexicana. Con esto se quiere decir que, si bien es claro el impacto del ámbito de lo social en la literatura, también queda demostrado cómo ésta puede generar, indudablemente, una pugna o increpación en aquél. Esta circunstancia debe mencionarse porque pudiera entenderse la presente investigación como una suerte de hegemonía social para establecer una interpretación de lo literario; sin embargo, no funciona de este modo. El cuento demuestra su capacidad de efecto al producir un debate directo en el imaginario colectivo de México como sucede, de modo irremediable, en cualquier literatura. Este último resultado debe acotarse aquí para crear una síntesis general de los aportes de este trabajo, los cuales, en su parte analítica, conducen al lector a encontrar esta coyuntura tan eficaz de la literatura para modificar la vida de los hombres.

Por otro lado, el recorrido elaborado ha respondido a las preguntas iniciales sobre las diversas manifestaciones del homoerotismo en la sociedad mexicana. El primer apartado, sin duda, estableció las bases para entender las formas en las cuales las formas de organización de la sociedad afectan a los individuos y los convierten en sujetos a través de un fino 
mecanismo de aprehensión. Por otro lado, este mecanismo, simbólica o tangiblemente, queda expuesto en los imaginarios espacio-temporales de los cuales se abrevó para conformar dicha perspectiva. El cuento, en este caso, funciona como un instrumento en sí mismo al momento de su proyección estética, pero, de un modo ineludible, es un elemento de confrontación por parte del quehacer literario. No hay duda de que cada uno de los cuentos aquí analizados conlleva una carga impensable de poder catártico, el cual puede traducirse en experiencia estética renovadora y confortante, pero, a la vez, amplía la perspectiva del lector sobre la cosmovisión que pudiera poseer. En síntesis, el cuento, desde el proceso de creación hasta el de su lectura, es un objeto precioso de trance que fija normas, valores o conductas, mas, a la par, puede desestabilizarlos, destruirlos o promover su modificación. Para ejemplificar esto, baste recordar los alcances de un texto como "Aventura de carnaval" de Amado Nervo, en el cual se expone, subrepticiamente, un anhelo perenne de apreciar y gozar de lo desconocido. Si bien la diégesis del texto queda frenada por una carga conductual irremediable para la época, no hay duda de que la añoranza de una sexualidad subversiva está latente y pugna por brotar de forma eficaz. En este caso, la máscara, elemento primordial para entender el peso simbólico del texto, no sólo es un artefacto de uso decorativo en un carnaval o en un baile, sino un verdadero artilugio mediante el cual el hombre cubre todas sus pulsiones con el fin de someterse a una identidad incuestionable.

Una cuestión similar ocurre en "Retrato de un estudiante" de Jaime Torres Bodet. Se trata de una apelación directa al sistema patriarcal y a las diferentes formas en las cuales se reproduce, sobre todo en el ámbito familiar. De este modo, una escena tan simple, como contemplar las burbujas del champagne en una estilizada copa, oculta una enorme capacidad de transformación en el individuo. Tal parece que esas burbujas son los deseos del protagonista que buscan emerger de un estado inferior y colocarse una superficie para ser 
observados y, a la vez, admirados por cualquiera. El cuento de Torres Bodet es inaugural con respecto a las formas de promover una sexualidad disidente aun en contra de los valores propuestos en el seno familiar, político o religioso. Lo cual lo coloca como parte de este canon soterrado que intenta abrirse paso, y a lo cual se suma la presente investigación.

Por otro lado, en un cuento tan emblemático como lo es "De amor es mi negra pena" de Luis Zapata, la mirada cobra un espacio privilegiado al brindar la peripecia del riesgo, pero también del placer. El protagonista del texto plantea un una encrucijada cruel creada por él mismo, pero, a la vez, por un ámbito exterior que se manifiesta contundentemente en su parte más intrínseca. Este personaje desea; no obstante, a la par trata de inclinar su deseo hacia lo correcto, lo digno de elogios y prestigio. El vituperio trata de eludirse, pero la única forma de hacerlo es la desaparición del deseo o la corporalidad, y como lo primero es casi una utopía higienista decimonónica, la segunda opción es la más viable.

Un vestido, cosa de lo más común, queda transformado en un leitmotiv, pero, a la vez, en una suerte de respuesta unívoca a las hegemonías del dispositivo de la sexualidad. Cuando un personaje usa una determinada vestimenta no sólo se está cubriendo, o descubriendo, de cualquier contingencia climática, además, está sumergiéndose en una gigantesca red de planos simbólicos que van desde la sexualidad, la clase y la raza, hasta la ubicación geográfica y los valores religiosos. De este modo, en "Amor propio" de Enrique Serna, el vestido es una cosa con la posibilidad de intercambiarse entre dos personajes marginales a su modo, aunque es, también, un estado de deseo y una formulación de la identidad a través de sus revestimientos más tangibles. El cuento entonces articular un motivo muy recurrente que escapa de la propia proceso de ficcionalización y alcanza la materialidad de una realidad.

Estos cuatro elementos - máscara, copa de champagne, mirada y vestido- funcionan como parte de una estructura narrativa en el plano formal; no obstante, en el caso del 
caparazón simbólico son puntos alegóricos de imprescindible valor. Lo mismo acontece con cada uno de los cuentos revisados en este trabajo: hay una puesta alegórica por parte de su configuración narrativa que ha sido actualizada desde la contraparte crítica. Así, los cuentos contenidos en los últimos cuatro apartados son connotaciones alegóricas con respecto a un sistema de valores, con el cual se ajustan o, por lo contrario, se manifiestan de forma insumisa. Queda muy claro que los cuentos de “Antecedentes (1921-1920)", remiten al lector a un universo inapelable en cuanto a sus estructuras de género y poder: a excepción de “Aventura de carnaval”, el travestimiento es un ardid con el fin de obtener ciertos beneficios que van desde el afecto de un enamorado evasivo, hasta la huida de un sistema judicial. El trastrueque de la identidad, si bien existe, obedece a otras metas un tanto disímiles a una disidencia sexual; sin embargo, a pesar de esta circunstancia, están incrustados en un juego de identidades bastante complejo y divertido, del cual resultan eficaces exponentes de la forma en la cual el hombre puede encontrar formas de representación diferentes a las impuestas. Los personajes pueden escapar de esta coartada y adquirir festivamente una linealidad sexo/género/deseo alterada, desde la perspectiva del poder, pero sumamente satisfactoria desde una perspectiva del deseo. Incluso, este ardid puede servir para regocijar a quienes ocultan su verdadera constitución del deseo al promover un acercamiento al pisaverde que ha sacudido sus fibras más íntimas con su aparente androginia.

Un apartado como "Exploración (1921-160)" crea una serie de concordancias paralelas entre el plano ficcional de la literatura y el plano verídico de la realidad. Los tres cuentos integrantes del capítulo -"Retrato de un estudiante", "Los machos cabríos" y "Los Malabé"- crean un paradigma asombroso de los modos en los cuales es afirmada o negada la identidad del sujeto, sobre todo del masculino. Los textos anotados formulan una acérrima lucha entre las jerarquías simbólicas del género y la sexualidad y las posibles alteraciones de 
éstas con base en las determinaciones de un individuo. El capítulo entonces confirma la pugna y, de algún modo, estas batallas se inclinan a uno u otro bando. Claro está que es más probable el triunfo de la sanción; sin embargo, la mera exhibición ya implica cierto desasosiego y modificación de los valores tradicionales de la masculinidad. En el caso de "Los machos cabríos" y de "Los Malabé" hay una reticencia muy severa por el entorno para confirmar el desvío como una irremediable forma de subversión que necesita un castigo o una cura. Los sitios de los cuales provienen estas sanciones están determinados por la medicina y la religión, respectivamente: la primera asume la "homosexualidad" como una enfermedad que es posible curar a través de un tratamiento quirúrgico, mientras que, la segunda, alude a la concepción del pecado, y los mecanismos mediante los que éste formula una ruptura en el seno familiar. Indudablemente, ambos sitios del poder flagelan a los personajes de los cuentos analizados para promover su destrucción o reacondicionamiento, según fuere el caso. Por otro lado, y como ya se dijo, "Retrato de un estudiante" convive más con una heterodoxia de la sexualidad y con las maneras en las que pudiera asumirse ésta que con la sanción. El protagonista del cuento formula un sutil discurso contestatario, el cual, sin duda, puede imaginar el lector que será concentrado en la adquisición de un revestimiento identitario subversivo o, al menos, en la reconciliación con el deseo disidente.

El tercer capítulo aporta a este trabajo la impronta del cambio. "Consolidación (19611990)" recorre cuatro cuentos que enarbolan una sexualidad diferente a la hegemónica; sin embargo, no son una suerte de panfletos; por lo contrario, plantean un cuestionamiento severo bajo los cuales se ha sostenido el patriarcado y la heterosexualidad hegemónicos sin proponer un algo como solución única o feliz. Los personajes de estos textos -"Los amigos", "Doña Herlinda y su hijo", "Perder a Orfeo" y "De amor es mi negra pena" - crean un debate inusitado en la literatura mexicana y, a la vez, instituyen un cambio en la misma que atraviesa 
la conformación de los estamentos de una sociedad. No obstante, a pesar de esta propuesta, los cuentos no están exentos de una terrible carga trágica, tal como se ha ido manifestando a lo largo del siglo XX en la literatura y arte homoeróticas de Occidente. La crueldad, el dolor infringido sobre el cuerpo, la absorción de la individualidad por parte de un sistema totalitario y la adquisición de dicho sistema como parte intrínseca de la identidad, incluso por parte del personaje marginal, son algunos de los elementos que se tuvieron en consideración al realizar la interpretación de los relatos anotados. El resultado fue una consideración de que este apartado, si bien concentraba cuentos en los cuales la homosexualidad era asumida directamente por los personajes en cuestión o tratada del mismo modo por el narrador, no había una respuesta satisfactoria por parte del entorno ni por los propios actantes en un papel subversivo. Así, el acontecimiento homoerótico quedaba aniquilado o, en el mejor de los casos, en un segundo plano para conservar cierta imagen frente al mundo. Sin embargo, aun tomando en cuenta este tinte trágico, es posible observar cómo hay una perenne búsqueda de sí mismos en los personajes estudiantes, lo cual conlleva a repensar los modelos fundacionales del dispositivo del poder, ya sea para modificarlos o destituirles su capacidad de daño sobre los otros.

Ahora bien, si el enfrentamiento con un universo adverso permeaba en el apartado anterior, en "Cuestionamiento (1991-2014)" hay un dejo de lucha pero con las mismas reglas que dominan el espacio marginado. “Amor propio” y “¿Te gusta el látex, cielo?” son relatos notoriamente contestatarios con respecto a cualquier tipo de encorsetamiento se refiere. Los protagonistas de los cuentos están involucrados en acontecimientos que los vuelven de bruces con una realidad poco convencional que, en algún punto o en muchos, los seduce irremediablemente. En consecuencia, más que la asimilación del homoerotismo, lo que aquí se observa es la lucha con la heteronormatividad y, paradójicamente, también con la 
homonormatividad. Pareciera que los dos personajes de los textos señalados están un punto indefinido que no está ubicado en ninguna de las dos concepciones de la sexualidad. Claro está, que este enfrentamiento confronta al lector directamente con los valores de una literatura posmoderna y, obviamente, con los mecanismos inusitados de operación de la teoría queer. Ambas posturas de análisis ofrecieron un panorama bastante amplio y propusieron interpretaciones que trajeron consigo el acercamiento a los nuevos modos en los cuales se concibe la disidencia sexual en la literatura mexicana de las últimas dos décadas.

El lector podrá observar que este recorrido ha recreado entonces modelos de representación que fluyeron desde el personaje travestido decimonónico hasta la posmoderna drag queen que, como un narciso mestizo e híbrido, seduce a su propio reflejo. Todo esto sin olvidar, por supuesto, al tímido adolescente que se asume como homosexual en la década de los veinte, al hombre que es sometido a cirugía para obtener su auténtica masculinidad, al sujeto que se enfrenta consigo mismo con el afán de acercarse a su objeto de deseo o al personaje que transgrede los valores de su familia y estado con el fin de obtener su verdadero placer.

Por otro lado, cabe mencionar que este trabajo surgió como una forma de señalar los modos en los cuales es latente la representación del homoerotismo en el cuento mexicano; no obstante, aún queda pendiente un trabajo que se dedique a advertir estas mismas representaciones en un plano más amplio que congregue los diferentes géneros y proporcione una perspectiva amplia y multiforme. Entonces, a esta labor crítica que todavía debe realizarse, el presente trabajo aporta una sugestiva forma de observar y organizar el cuento mexicano con base en un motivo recurrente como lo es el homoerotismo. Así, el proyecto de investigación prevalece, aunque el avance es ya muy significativo. 
BIBLIOGRAFÍA

AMÍCOLA, JOSÉ. Camp y posvanguardia. Argentina: Paidós, 2000.

-. "Hell has no limits: de José Donoso a Manuel Puig", en Nicolás Rosa y otros. Pról. de Dieter Ingenschay. Desde aceras opuestas. Literatura/cultura gay y lesbiana en Latinoamérica. Madrid: Iberoamericana/Vervuert, 2006.

ARREDONDO, INÉS. Obras completas. México: Siglo XXI, 2002.

ARROYO, JOSSIANA. "Historias de familia: migraciones y escritura homosexual en la literatura puertorriqueña" en Revista Canadiense de Estudios Hispánicos. Montreal: McGill University, 2002, vol. 26, num. 3.

BALDERSTON, DANIEL Y DONNA J. GUY. Sexo y sexualidades en América Latina. Argentina: Paidós, 1998.

-. El deseo, enorme cicatriz, luminosa. Ensayos sobre homosexualidades latinoamericanas. Buenos Aires: Beatriz Viterbo, 2004.

BAZÁN, OSVALDO. Historia de la homosexualidad en la Argentina. De la Conquista de América al siglo xxi. Buenos Aires: Marea, 2006.

BLANCO, JOSÉ JOAQUÍN y otros. Triple función. México: Quimera, 2007.

-. El castigador. México: Era, 1995.

-. Mátame y verás. México: Era, 1994.

-. Calles como incendios. México: Océano, 1981.

-. Las púberes canéforas. México: Océano, 1983.

BODET, JAIME TORRES. El juglary la domadora y otros relatos desconocidos. Pról. de Luis Mario Schneider. México: El Colegio de México, 1992.

BORRILLO, DANIEL. Homofobia. Barcelona: Bellaterra, 2001. 
BOSWELL, JOHN. Cristianismo, tolerancia social y homosexualidad: Los gays en Europa Occidental desde el comienzo de la Era Cristiana hasta el siglo XVI. Trad. de MarcoAurelio Galmarini. Barcelona: Muchnik, 1992.

BOURDIEU, PIERRE. La dominación masculina. Barcelona: Anagrama, 2000.

BUTLER, JUDITH. El género en disputa: el feminismo y la subversión de la identidad. Trad. de Mónica Mansour y Laura Manríquez. México: Paidós, 2001.

-. "Sujetos de sexo/género/deseo", en Joan W. Scott y otros. Feminismos literarios. Madrid: Arco/Libros, 1999.

-. Mecanismos psíquicos del poder. Teorías sobre la sujeción. Trad. de Jacqueline Cruz. Madrid: Cátedra, 2001.

-. Cuerpos que importan. Sobre los límites materiales y discursivos del sexo. Buenos Aires: Paidós, 2010.

-. Deshacer el género. Trad. de Patricia Soley-Beltrán. Barcelona: Paidós, 2006.

CALVA, JOSÉ RAFAEL. Utopía gay. México: Oasis, 1983.

CAPISTRÁN, MIGUEL Y MICHAEL K. SCHUESSLER. México se escribe con J. Una bistoria de la cultura gay. México: Planeta, 2010.

CARBONELL, NEUS Y MERI TORRAS. Feminismos literarios. Madrid: Arco/Libros, 1999.

CASTREJÓN, EDUARDO. Los cuarenta y uno: novela crítico social. México: 1906.

CÓCCIOLI, CARLO. Fabrizio Lupo, Trad. de Aurelio Garzón del Camino. México: Compañía General de Ediciones, 1957.

COLINA, JOSÉ DE LA. Ven, caballo gris, Pról. de Juan Coronado. Xalapa: Universidad Veracruzana, 2007.

CÓRDOBA, DAVID. "Teoría queer: reflexiones sobre sexo, sexualidad e identidad. Hacia una politización de la sexualidad", en Marcelo Soto y otros. Teoría queer. Políticas bolleras, maricas, trans, mestizas. Madrid: Egales, 2005.

CUÉLLAR, JOSÉ TOMÁS DE. Historia de Chucho el Ninfo. México: Porrúa, 1975. 
FERRETIS, JORGE. El coronel que asesinó un palomo y otros cuentos. México: Fondo de Cultura Económica, 1952.

FOSTER, DAVID WILLIAM. Producción cultural e identidades homoeróticas. San José: Universidad de Costa Rica, 2000.

-. Gay and LesbianThemes in Latin American Writing. Austin: University of Texas Press, 1991.

-. Ensayos sobre culturas homoeróticas latinoamericanas. Ciudad Juárez: Universidad Autónoma de Ciudad Juárez, 2009.

FOUCAULT, MICHEL. Historia de la sexualidad v. 1. Madrid: Siglo XXI, 1995.

-. Los anormales. Buenos Aires: Fondo de Cultura Económica, 2010.

-. La arqueología del saber. Trad. de Aurelio Garzón del Camino. México: Siglo XXI, 2010.

GAMBOA, FEDERICO. Del natural. México: Eusebio Gómez de la Puente, 1915. GAMBA, SUSANA BEATRIZ, et al. Diccionario de estudios de género y feminismos. Buenos Aires: Biblos, 2009.

GIDENS, ANTONY. La transformación de la intimidad: sexualidad, amor y erotismo en las sociedades modernas. Trad. de Benito Herrera Amaro. Madrid: Cátedra, 1998.

GONZÁLEZ DE ALBA, LUIS. Agapi Mu. México: Cal y Arena, 1993.

-. Cielo de invierno. México: Cal y Arena, 1999.

-. El vino de los bravos. México: Katún, 1981.

GUASH, ÓSCAR. La crisis de la heterosexualidad. España: Laertes, 2000.

HALPERIN, DAVID. San Foucault. Para una hagiografía gay. Trad. de Mario Serrichio. Argentina: El cuenco de plata, 2007.

INGESCHAY, DIETER. Desde aceras opuestas. Madrid: Iberoamericana/Vervuert, 2006. 
JITRICK, NOÉ. Verde es toda teoría. Literatura. Semiótica. Psicoanálisis. Lingüistica. Buenos Aires: Liber Editores, 2010.

KAMINSKY, AMY. "Hacia un verbo queer", en Revista Hispanoamericana. Pittsburgh, octubre-diciembre de 2008, vol. LXXIV, núm. 225, p. 889

LAMAS, MARTHA. Cuerpo: diferencia sexual y género. México: Taurus, 2002.

-. El género: la construcción cultural de la diferencia sexual. México: UNAM, 2003.

LANCELOTI, A. MARIO. De Poe a Kafka. Para una teoría del cuento. Argentina: Editorial Universitaria, 1965.

LIZARRAGA CRUCHAGA, XABIER. Una bistoria sociocultural de la homosexualidad: notas sobre un devenir silenciado. México: Paidós, 2003.

LIST REYES, MAURICIO. Jóvenes corazones gay en la Ciudad de México. Puebla: Benemérita Universidad Autónoma de Puebla, 2005.

LLAMAS, RICARDO. Construyendo sidentidades. Estudios desde el corazón de una pandemia. Madrid: Siglo Veintiuno Editores, 1995.

-. Teoría torcida. Prejucios y discursos en torno a la "bomosexualidad. Madrid: Siglo xxi, 1998.

LÓPEZ PÁEZ, JORGE. Doña Herlinda y su bijo y sus otros hijos. México: Fondo de Cultura Económica, 1993.

LUMSDEM, IAM. Homosexualidad, sociedad y estado en México. México: Sol Ediciones/Canadan Gay Archives, 1991.

MALDONADO, JOSÉ CEBALLOS. Después de todo. México: Diógenes, 1969.

MARK MONDIMORE, FRANCIS. Una historia natural de la bomosexualidad. Barcelona: Paidós, 1998.

MARQUET, ANTONIO. iQue se quede el infinito sin estrellas! La cultura gay a fin de milenio. México: Universidad Autónoma Metropolitana, 2001.

-. El crepuisculo de heterolandia: mester de jotería: ensayos sobre cultura de las exuberantes tierras de la Nación Queer. México: Universidad Autónoma Metropolitana, 2006. 
MECCIA, ERNESTO. La cuestión gay. Un enfoque sociologico. Buenos Aires: Gran Aldea Editores, 2006.

MELO, JUAN VICENTE. Los muros enemigos. Xalapa: Universidad Veracruzana, 2007.

MENDIOLA, VÍCTOR MANUEL. Sol de mi antojo. Antología poética de erotismo gay. México: Plaza \& Janés, 2001.

MERUANE, LINA. Viajes virales. Santiago de Chile, Fondo de Cultura Económica, 2012.

MIGUEL BARBACHANO PONCE. El diario de José Toledo. México: Premiá, 1988.

MILLINGTON, MARK. Hombres in/visibles. La representación de la masculinidad en la ficción latinoamericana, 1920-1980. Bogotá: Fondo de Cultura Económica, 2007.

MONSIVÁIS, CARLOS. Que se abra esa puerta. Crónicas y ensayos sobre la diversidad sexual. Pról. de Alejandro Brito. México: Paidós, 2010.

-. Salvador Novo, lo marginal en el centro. México: Era, 2000.

MONTESINOS, RAFAEL y otros. Perfiles de la masculinidad. México: UAm/Plaza y Valdés, 2007.

MUÑOZ, MARIO. De amores marginales. México: Universidad Veracruzana, 1996.

- y LEÓN GUILLERMO GUTIÉRREZ. Amor que se atreve a decir su nombre. Antología del cuento mexicano de tema gay. Xalapa: Universidad Veracruzana, 2014.

NERVO, AMADO. Obras completas. Madrid: Aguilar, 1972.

NOVO, SALVADOR. La estatua de sal, Pról. de Carlos Monsiváis. México: Consejo Nacional para la Cultura y las Artes, 1998.

NÚÑEZ BECERRA, FERNANDA. La prostitución y su represión en la Ciudad de México (siglo XIX). México: Gedisa, 2002. 
NUÑEZ NORIEGA, GUILLERMO. Sexo entre varones. Poder y resistencia en el campo sexual. México: El Colegio de Sonora, 1994

OJEDA, JORGE ARTURO. Octavio. México: Fontamara, 1999.

-. Personas fatales. México: Mester, 1975.

-. Muchacho solo. México: Grijalbo, 1976.

PAVÓN, ALFREDO. Cuento de segunda mano. Xalapa: Universidad Veracruzana, 1998.

PHILIPHE, ARIES y otros. Sexualidades Occidentales. Trad. de Carlos García Velasco. México: Paidós, 1987.

PIMENTEL, LUZ AURORA. El relato. México: UNAM/Siglo XXI.

QUIROGA, JOSÉ Y DANIEL BALDERSTON. Sexualidades en disputa. Homosexualidades, literatura y medios de comunicación en América Latina. Buenos Aires: Libros del Rojas, 2005.

RAMÍREZ RODRÍGUEZ, JUAN CARLOS y otros. Masculinidades. El juego de género de los hombres en el que participan las mujeres. México: Plaza y Valdés, 2008. RODRÍGUEZ GALVÁN, IGNACIO. Manolito el pisaverde y otros cuentos. Pres. de Ignacio Trejo Fuentes. Puebla: Premiá, 1984.

RODRÍGUEZ, ÓSCAR EDUARDO. El personaje gay en la obra de Luis Zapata. México: Fontamara, 2006.

RUSE, MICHAEL. La homosexualidad. Trad. de Carlos Laguna. Madrid: Cátedra, 1989.

SCHULZ-CRUZ, BERNARD. Imágenes gay en el cine mexicano. Tres décadas de jotería 1970-1999. México: Ediciones Coyoacán, 2008.

SÁENZ, JAVIER, "Del contexto sociopolítico de surgimiento de la teoría queer. De la crisis del sida a Foucault", en David Córdoba y otros. Teoría queer. Politicas bolleras, maricas, trans, mestizas. Madrid: Egales, 2005. 
SCHNEIDER, LUIS MARIO. La novela mexicana, entre el petróleo, la homosexualidad y la política. México: Nueva Imagen, 1997.

SERNA, ENRIQUE. Amores de segunda mano. México: Cal y Arena, 2006.

SIMONIS, ANGI. Cultura, homosexualidad y homofobia. Barcelona: Laertes, 2007.

TEUTLE LÓPEZ, ALBERTO, et al. Florilegio de deseos. Nuevos enfoques, estudios y escenarios de la disidencia sexual y genérica. Puebla: Benemérita Universidad Autónoma de Puebla, 2010.

TORRES BODET, JAIME. El juglar y la domadora. Pról. de Luis Mario Schneider. México: El Colegio de México, 1992.

TORRES, VÍCTOR FEDERICO. "Del escarnio a la celebración. Prosa mexicana del siglo xx", en Teresa del Conde y otros. México se escribe con J. Una historia de la cultura gay. pról. de Luis Zapata. México: Planeta, 2010.

TRUEBA LARA, JOSÉ LUIS. Historia de la sexualidad en México. México: Grijalbo, 2008.

VÁZQUEZ RENTERÍA, VÍCTOR HUGO. Póquer con dama: cinco cuentistas mexicanos. Pról. de Alfredo Pavón. Veracruz: Ivec, 2007.

VIDARTE, PACO y otros. Teoría queer. Madrid: Egales, 2005.

VILLAFUERTE, NADIA. ¿Te gusta el látex, cielo? México: Fondo Editorial Tierra Adentro, 2008.

WITTIG, MONIQUE. El pensamiento heterosexual y otros ensayos. Barcelona: Egales, 2006.

ZAPATA, LUIS. Ese amor que hasta ayer nos quemaba. México: Posada, 1989.

-. El vampiro de la colonia Roma. México: Grijalbo, 1979.

-. La hermana secreta de Angélica María. México: Cal y Arena, 1989.

-. Melodrama. México: Enjambre, 1983.

ZANOTTI, PAOLO. Gay. La identidad homosexual de Platón a Marlene Dietrich. Trad. de Nuria Martínez Deaño. México: Fondo de Cultura Económica, 2010. 